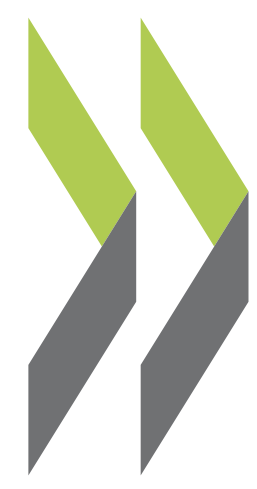

OECD Economics Department Working Papers No. 312

\section{Product and Labour Markets} Interactions in OECD Countries

\section{Giuseppe Nicoletti,}

Andrea Bassanini, Ekkehard Ernst, Sébastien Jean, Paulo Santiago, Paul Swaim 
Organisation de Coopération et de Développement Economiques

Organisation for Economic Co-operation and Development

14-Dec-2001

ECONOMICS DEPARTMENT

English text only

PRODUCT AND LABOUR MARKETS INTERACTIONS IN OECD COUNTRIES

ECONOMICS DEPARTMENT WORKING PAPERS NO. 312

by

Giuseppe Nicoletti, Andrea Bassanini, Ekkehard Ernst, Sébastien Jean, Paulo Santiago and Paul Swaim

Almost all Economics Department Working Papers are now available through OECD's Internet Web site at http://www.oecd.org/eco 


\section{ABSTRACT/RÉSUMÉ \\ Product and Labour Markets Interactions in OECD Countries}

This paper analyses several of the cross-market effects of policies aimed at influencing outcomes in product and labour markets. Focusing on subsets of OECD countries, we look at the implications of product market competition for industry wages and overall employment, and the implications of labour market arrangements for industrial structure and innovation potential. We also look at the potential implications of regulatory reform for employment security and income inequality. We provide empirical evidence on long-run policy interactions by exploiting the cross-country and intersectoral dimensions of the data, though the analysis of employment uses also the time-series dimension. To this end, we rely on a large set of indicators of (economy-wide) labour market policies and institutions and (economy-wide, industry-specific and time-varying) product market regulations. We find that: (a) anticompetitive product market regulations have significant negative effects on non-agricultural employment rates; (b) wage premia generally increase with product market regulations that curb competition, although premia tend to revert to lower levels as market mechanisms are displaced by regulation (e.g. public monopolies); (c) the effects of employment protection policies on innovation activity are significant, with their sign and magnitude depending on industrial relations and technological regimes; (d) countries having stricter regulations tend to specialise in industries with relatively lower R\&D intensity and wages; (e) labour market policies and institutional arrangements have significant unintended effects on the size distribution of firms; (f) product market liberalisation may lead to less job security in the most regulated industries, but no empirical support was found for concerns that it could result in a permanent increase in earnings inequality.

JEL classification: L50, J50, E24, J31, L10, O31

Keywords: Regulation, industrial relations, employment, wage premia, firm size, industry specialisation, innovation, panel data

$$
* * * * *
$$

Interactions entre les marchés des produits et du travail dans les pays de l'OCDE

Ce papier analyse plusieurs effets inter-marchés que peuvent avoir des mesures de politique visant à influencer les résultats sur les marchés des produits et du travail. Nous concentrant sur un sous-ensemble de pays de l'OCDE, nous analysons les implications de la concurrence sur le marché des produits pour les salaires industriels et l'emploi total, et les implications des arrangements sur le marché du travail pour la structure industrielle et le potentiel d'innovation. Nous examinons également les implications potentielles de la réforme de la réglementation pour la sécurité de l'emploi et les inégalités des revenus. Nous avançons de l'évidence empirique concernant des interactions politiques à long terme en exploitant les dimensions transversales et intersectorielles de la base de données, bien que l'analyse du niveau de l'emploi utilise également la dimension temporelle. A cette fin, nous nous basons sur un large ensemble d'indicateurs de la réglementation et des institutions du marché du travail (au niveau national) et de la réglementation du marché des produits (au niveau national et sectoriel et variant dans le temps). Nous trouvons: (a) que la réglementation anti-compétitive du marché des produits a des effets négatifs significatifs sur le taux d'emploi nonagriculturel ; (b) que les primes salariales en général augmentent avec une réglementation du marché des produits qui diminue la concurrence, même si les primes ont tendance à se réduire si des mécanismes de marché sont remplacés par la régulation (p. ex. les monopoles publics); (c) que les effets d'une politique de protection de l'emploi sur l'activité innovatrice sont significatifs, mais leur signe et la taille de leur impact dépend des relations du travail et des régimes technologiques; (d) que les pays ayant une protection de l'emploi plus restrictive ont tendance à se spécialiser dans des industries à intensité de R\&D et salaire plus faibles; (e) que les politiques et arrangements institutionnels du marché du travail ont des effets significatifs inattendus sur la distribution des firmes par taille ; (f) que la libéralisation du marché des produits peut réduire la sécurité de l'emploi dans des industries les plus réglementées, mais qu'aucun support empirique n'a pu être trouvé quant à une augmentation permanente des inégalités des revenus.

Classification JEL: L50, J50, E24, J31, L10, O31

Mots clés: Réglementation, relations du travail, emploi, primes salariales, taille d'entreprise, spécialisation industrielle, innovation

Copyright: OECD 2001

Applications for permission to reproduce or translate all, or part of, this material should be made to: Head of Publications Service, OECD, 2 rue André-Pascal, 75775 PARIS CEDEX 16, France. 


\section{TABLE OF CONTENTS}

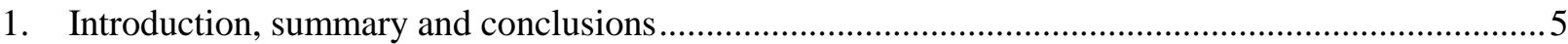

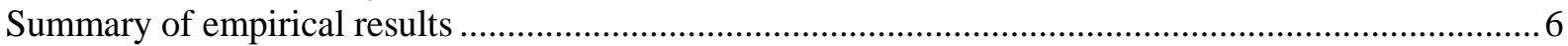

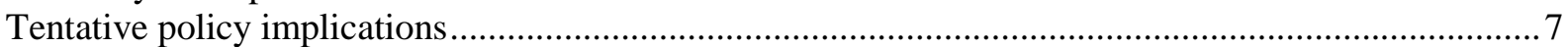

2. Effects of market interactions on industrial structure and innovation potential ................................ 8

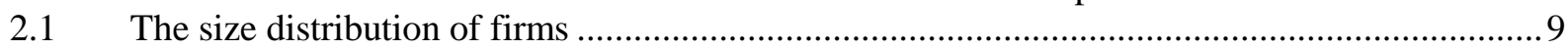

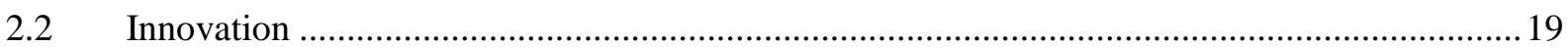

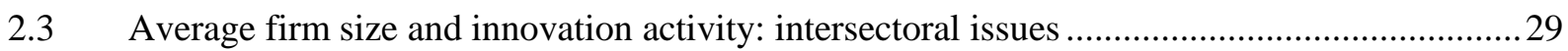

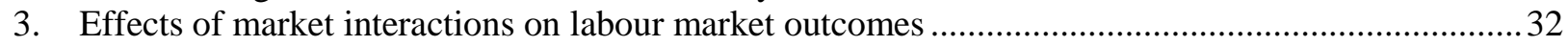

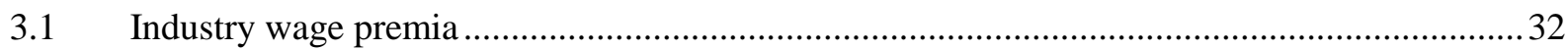

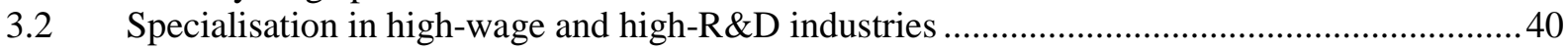

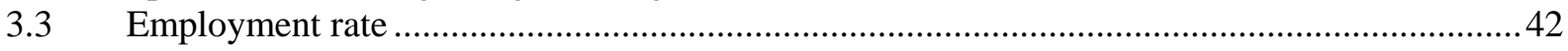

4. Effects of market interactions on insecurity and inequality …....................................................51

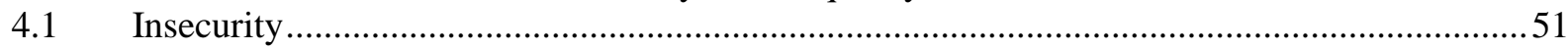

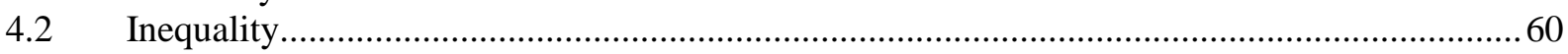

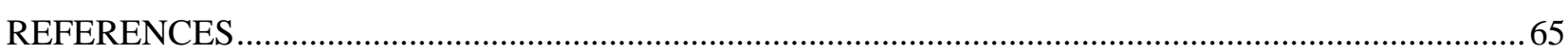

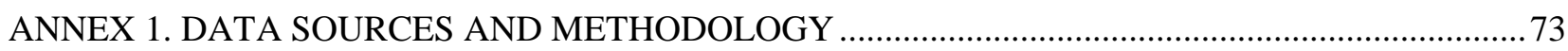

1. Structure and performance of product and labour markets. ............................................................ 73

$1.1 \quad$ Indicators of innovative activity: definitions, sources and limitations .....................................

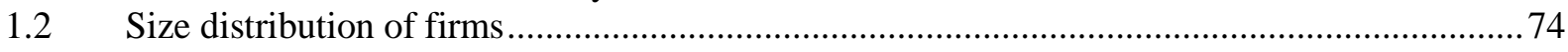

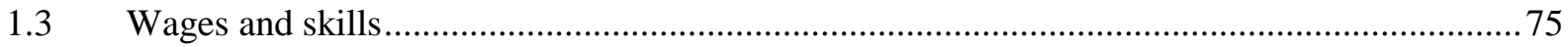

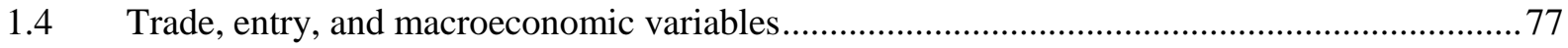

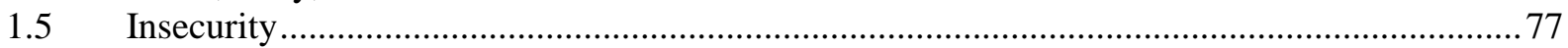

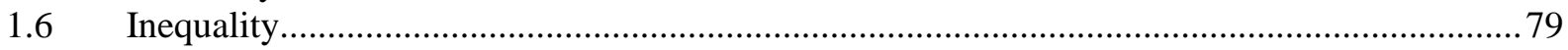

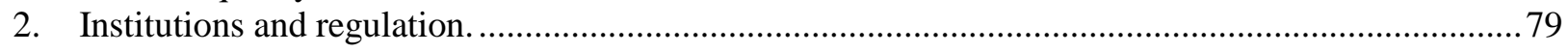

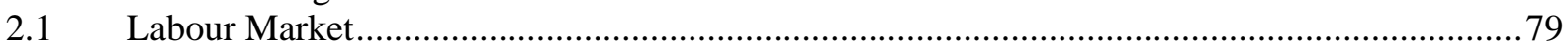

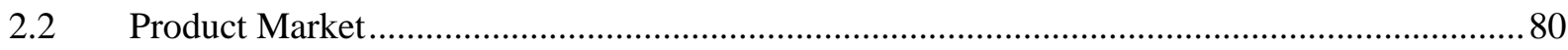

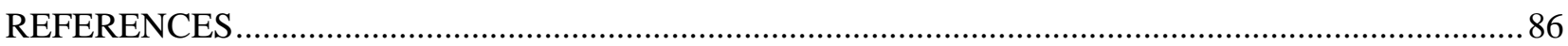

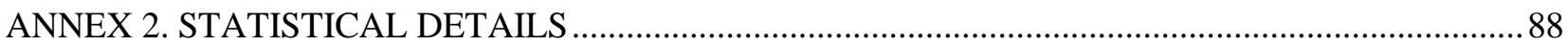

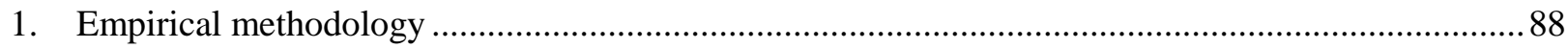

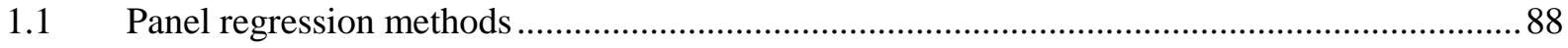

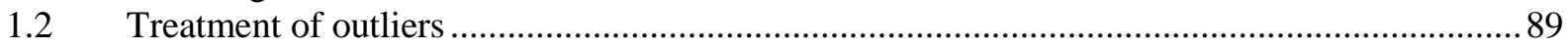

2. Decomposition of within and between-industry effects and specialisation indicators.......................89

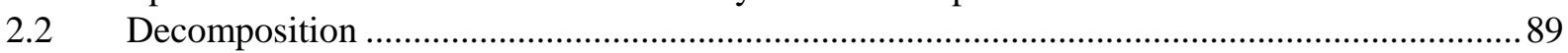

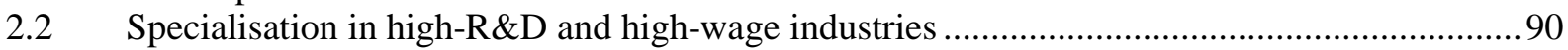

3. Additional background material and empirical results.................................................................. 91

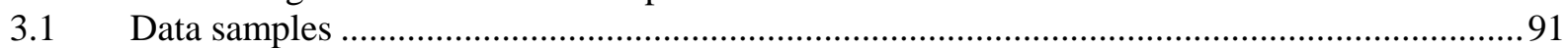

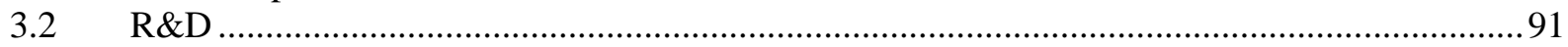

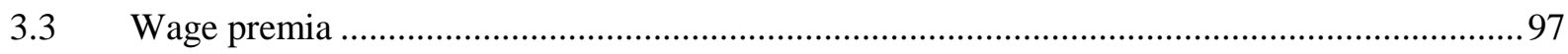

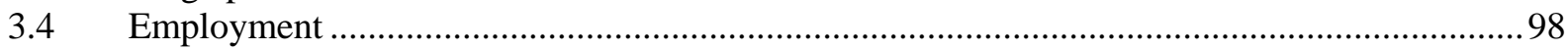




\section{ECO/WKP(2001)38}

3.5 Insecurity and inequality

102

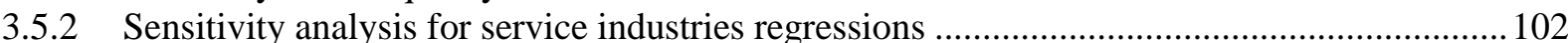

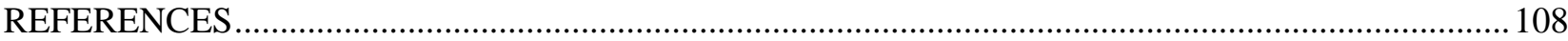


ECO/WKP(2001)38

\title{
PRODUCT AND LABOUR MARKETS INTERACTIONS IN OECD COUNTRIES ${ }^{1}$
}

\author{
by \\ Giuseppe Nicoletti, Andrea Bassanini, Ekkehard Ernst, Sébastien Jean, Paulo Santiago \\ and Paul Swaim
}

\section{Introduction, summary and conclusions}

1. Over the past decade, the levels and trend growth rates of GDP, and the relative growth contributions of employment and productivity, varied widely across OECD countries (OECD, 2000a). At the same time, countries differed significantly in terms of employment and unemployment outcomes (OECD, 1994a, 1999b). A broad range of policies and institutional arrangements influenced these differences (OECD, 2000b; Ahn and Hemmings, 2000). There has been extensive research and policy analysis, notably to support the OECD Jobs Strategy and the OECD Growth Project, on best-practice policies affecting the product and labour markets. ${ }^{2}$ However, to date relatively little attention has been paid to the influence of product (labour) market arrangements on outcomes in labour (product) markets.

2. The aim of this paper is to identify some of the channels through which cross-market effects come about and to assess their policy relevance. The paper attempts at quantifying the importance of the market interactions driven by product and labour market policies and investigate some of the possible policy trade-offs between efficiency and equity goals. Improved understanding of these potential linkages and trade-offs can help design and implement regulatory reforms.

3. The analysis focuses on the implications of product market competition (or the lack of it) for industry wages and overall employment, and the implications of labour market arrangements for the industrial structure of OECD economies and their innovation potential. In order to address a frequent policy concern, some preliminary analysis is also made of the potential implications of product market regulatory reform for employment security and income inequality. Throughout the document, the study of market interactions controls for a number of policy influences specific to each market (e.g. the effects of hiring and firing restrictions and wage bargaining systems on employment and employment security). The analyses deal mainly with long-run policy interactions by exploiting the cross-country and intersectoral dimensions of the data. There is no attempt to investigate other possible interactions of product and labour market arrangements, or interactions between them and other markets (e.g. capital markets) or with macro policies.

1. Giuseppe Nicoletti, Andrea Bassanini and Ekkehard Ernst work in the OECD Economics Department; Sébastien Jean works in CEPII, Paris, and was a consultant to the OECD Economics Department when this paper was written; Paulo Santiago and Paul Swaim work in the OECD Directorate for Education, Labour and Social Affairs. The authors wish to thank Jorgen Elmeskov, Dirk Pilat, Mike Feiner, John Martin and Ignazio Visco for useful comments on previous drafts of this paper. The opinions expressed are personal and do not engage the OECD or its Member countries.

2. See OECD (1994a, 1994b, 1997b, 1999b, 2001a), Gonenc et al. (2000). 
4. Previous studies (e.g. OECD 1995, 1996) have looked at the effects of product market competition on product and labour market performance, proxying competitive pressures by means of measures of market power (concentration, mark-ups, import penetration, etc.). However, as competitive pressures are not necessarily monotone in those measures (see e.g. Boone 2000a), focusing on regulations adds an important dimension to analysis in this area ${ }^{3}--$ and also provides for a direct link to policy. Such analysis has already been undertaken for the impact of labour market policies on labour market performance (e.g. Scarpetta, 1996), but not for the impact on product markets. The analytic strategy of this paper relies on the large set of indicators of (economywide) labour market policies and institutions and product market regulations that were assembled in the context of the OECD Jobs Strategy and the Regulatory Reform Project (OECD, 1999a; OECD, 1999b). To make intersectoral and macro analyses feasible, these indicators were supplemented and extended to cover a finer industry breakdown and several time periods.

5. The paper has three parts. Section II looks at the implications of market interactions for key outcomes in the product market. Section III looks at the implications of market interactions for labour market outcomes. Section IV looks at the effects of market interactions on employment security, and on earnings and incomes inequality.

\section{Summary of empirical results}

6. Interactions between the labour and product markets are analysed by means of reduced-form models, employing a variety of econometric techniques, and proxying competitive pressures (and their determinants) by cardinal indicators of regulations and institutions in the two markets. These indicators cover mainly $i$ ) industryspecific and economy-wide product market regulations that restrict market mechanisms, including international trade; ii) hiring and firing restrictions; iii) tax and benefit policies (tax wedges, unemployment insurance); and iv) industrial relations arrangements (bargaining co-ordination and centralisation, unionisation, administrative extension of collective agreements). The main results of the empirical analysis are the following:

- Even controlling for a number of policy and institutional factors affecting the labour market, anticompetitive product market regulations (e.g. establishing entry barriers in potentially competitive markets or unduly restricting market mechanisms) were found to have significant negative effects on non-agricultural employment rates of OECD countries. The empirical results suggest that, in some countries, the product market regulatory environment may account for up to 3 percentage points of deviations of the employment rate from the OECD average.

- The estimated wage premia in manufacturing industries were found to increase with weaker product market competition and product market regulations that curb competitive pressures or establish barriers to entry (such as tariff and non-tariff barriers or licensing restrictions). However, in non-manufacturing industries, the relationship between wage premia and regulation appears to be hump-shaped, with premia declining where state control and heavy regulation are more common (such as in utilities). Such results could imply that regulation is successful in preventing rents and rent-sharing, but are more likely to reflect regulatory failures leading to low-productivity traps and/or the existence of non-pecuniary rents.

- The evidence also points to significant effects of employment protection policies on innovation activity in manufacturing. However, the impacts differ depending on industrial relations regimes (e.g. bargaining arrangements, business associations, business codes of conduct, etc.) and the technology level of the industry concerned. On balance, the results obtained suggest that strict employment protection policies are likely to negatively affect $R \& D$

3. For instance, the average mark-up may increase as a result of new entry if inefficient incumbents are driven out of the market. 
intensity, especially in high-tech industries of countries where industrial relation systems are relatively decentralised. Similar effects were found in low-tech industries of countries with relatively co-ordinated industrial relations systems. No significant cross-market interactions could be found in other situations, i.e. high-tech industries in countries with relatively coordinated industrial relations systems or low-tech industries where such systems are relatively decentralised. These differences may reflect differences in the innovation process across industries as well as the role of industrial relations arrangements in affecting how firms satisfy the need for skilled labour to cope with innovation.

- There is some evidence of a systematic cross-country relationship between differences in product and labour market regulations and differences in industry specialisation, with countries having stricter regulations specialising in industries with relatively lower R\&D intensity and wages. No evidence was found as to the effect of industrial relations systems on industry specialisation.

- Several labour market policies and institutional arrangements were found to affect the size distribution of firms. Hiring and firing restrictions tend to result in a distribution of firms towards lower sizes in most industries. On the other hand, administrative extension of collective agreements and centralisation/co-ordination of collective bargaining tend to be positively associated with larger average firm size.

- On balance, labour market policies (e.g. concerning EPL and unemployment benefit systems) appear to be more relevant for employment security than product market regulations. The net effect of product market regulations on overall employment security could not be clearly identified, although it would seem that increasing market competition may lead to less security in the most regulated industries. In particular, there is some evidence that anticompetitive product market regulations may tend to reduce the incidence of job losses that result in longterm unemployment. However, these considerations related to insecurity among the employed need to be seen jointly with the evidence concerning the employment impacts of product market regulation.

- No empirical support was found for concerns that product market liberalisation could result in a permanent increase in aspects of earnings inequality.

\section{Tentative policy implications}

7. Policies in product and labour markets are essentially aimed at influencing outcomes in the markets to which they directly apply. However, the empirical findings of this paper suggest that policy interactions between labour and product markets can have significant efficiency effects, sometimes having an impact comparable to within-market policy influences. For instance, in the United States, labour and product market arrangements appear to have been equally important in determining R\&D intensities above the OECD average; in some European countries, anticompetitive product market regulations and strict employment protection policies appear to have contributed equally to keeping employment rates below the OECD average. Therefore, accounting for the potential cross-market effects of product and labour market policies appears to be an important element of good policy design.

8. More specifically, the empirical results suggest the following policy conclusions:

- The removal of barriers to trade and competition in potentially competitive product markets can be a complement to labour market reforms aimed at increasing long-run employment levels of OECD countries. The analysis in this paper suggests that part of the effects on employment derive 
from a decline in the rent-sharing component of wages. Further effects may also be expected from a specialisation in industries that have a higher growth potential.

- A relaxation of hiring and firing restrictions, increasing job turnover and possibly reducing job security among the employed, is either mildly positive or neutral in some cases with respect to its effect on innovative activity. This potential positive effect can be reinforced by an increased specialisation in $\mathrm{R} \& \mathrm{D}$ intensive industries.

- By affecting the size distribution of firms, labour market policies (such as employment protection legislation, taxation or administrative extension of collective agreements) may have unintended side-effects on industry structure. The issue of optimal firm size is complex and outside the scope of this paper. However, to the extent that firm size may have repercussions on performance in particular industries, these side-effects should be considered in designing labour market policies.

- Cross-market effects of product market regulations on employment security appear to be less important than own-market effects of labour market policies, particularly EPL. Nonetheless, the preliminary evidence suggests that product market reforms that increase competition may sometimes result in decreased employment security for certain groups of workers. These findings suggest that trade-offs may be present when setting regulatory policy, because changes in regulation that enhance efficiency and total employment may also diminish employment security for certain workers. However, the terms of any such trade-off are complex, because product and labour market regulations that enhance security for certain workers ("insiders") appear also to result in reduced security for others ("outsiders"). Furthermore, the available evidence does not allow us to quantify these impacts with any precision.

\section{Effects of market interactions on industrial structure and innovation potential}

9. This section examines the effects of labour market regulations and arrangements on the innovation potential of firms and their size distribution. ${ }^{4}$ Innovation activity, measured for instance by R\&D intensity, has been shown to be one of the most significant explanations of differences in GDP growth across countries and over time (see Cameron, 1998, 2000; Ahn and Hemmings, 2000; Guellec and Van Pottelsberghe, 2001; and Bassanini et al., 2001). The optimum firm size distribution in different industries is difficult to establish, but differences in the size distribution of firms across countries are of policy interest for three related reasons. First, they are usually associated with different industry specialisation and production patterns. Second, firm size is strongly correlated with important determinants of GDP and employment growth, such as R\&D intensity, the choice of the capital-labour ratio and wages (see below), though the direction of causation is often uncertain. Third, policies may distort the size distribution away from that implied by firms operating at their minimum efficiency scale based on technological considerations alone, resulting in overall efficiency losses.

10. There are numerous labour market policies and institutions that are potentially relevant for explaining the size distribution and the innovation activity of firms, such as industrial relations systems (including bargaining mechanisms and unionisation) and employment protection legislation (EPL). In addition, the analysis controls for direct product market influences originating from entry barriers facing domestic and/or foreign producers, and regulations and/or ownership structures that constrain competition. These policy and institutional influences have a relatively clear grounding in economic analysis (see below) and each of them can be summarised by an indicator that varies across countries and, in some cases, across industries. Indicators of this kind are drawn from previous OECD work on labour and product

4. Most variables used in the empirical analysis are expressed in logarithms because, despite the use of ratios, their ranges often involve different magnitudes (as is the case for R\&D intensity, wages and tariff barriers). Firm size regressions are robust to alternative linear and log-linear specifications. Log-log functional forms have the advantage that coefficient estimates can be directly interpreted as elasticities. 
markets and from a database of industry-specific product market regulations constructed specifically for this project. ${ }^{5}$ It should be noted at the outset that the indicators used in empirical analysis are relatively crude proxies of the complex phenomena they are meant to describe. For instance, the indicator for EPL does not take into account differences in the enforcement of legislative provisions, and the indicators of bargaining centralisation and co-ordination may be subject to several observations (for a survey, see Flanagan, 1999). Table 1 provides details on the cross-country and cross-industry variability of policy and institutional indicators. The empirical analysis is performed at both the aggregate level, in a cross-section of 26 OECD countries, and at the industry level, using a panel of up to 18 OECD countries and 30 manufacturing and non-manufacturing industries. ${ }^{6}$

\subsection{The size distribution of firms}

11. Recent research has argued that the size distribution of firms is crucially determined by institutional factors (e.g. Henrekson and Johansson, 1999). Most of the attention has been devoted to the influence of labour market arrangements on firm size. Some studies have related minimum wages (Blau, 1987), taxation policies (Blau, 1987; Schuetze, 2000) and EPL (Centeno, 2000; Nicoletti et al., 2001) to self-employment. However, these can explain at best the share of sole-proprietor firms, not the whole size distribution of firms with dependent employees. Recently, Davis and Henrekson (1999) have argued that peculiarities in the size distribution of Swedish firms can be related to wage bargaining mechanisms, EPL and taxation.

12. Centralisation of wage negotiations (as well as a strong role for unions in countries with decentralised wage settings) may affect the size distribution by imposing a compressed structure of wages inside and across firms. Existing evidence shows that in decentralised labour markets wages grow with firm size (Brown and Medoff, 1989; Davis and Haltiwanger, 1991, 1996; Oi and Idson, 1999). This is mainly because small firms tend to choose more labour-intensive technologies due to scale economies in physical capital. ${ }^{7}$ Moreover, smaller employers have a greater preference for flexibility and idiosyncrasy in wage determination (Davis and Henrekson, 1999), which tends to be curbed in centralised settings. Thus, by raising the relative labour costs of small employers and reducing the scope for diversified wage structures, wage compression tends to favour large over small firms.

13. There are several ways in which hiring and firing restrictions may affect the size distribution of firms, sometimes in opposite directions. The costs of labour readjustments imposed by EPL may be smaller in large firms, because they may face less demand uncertainty, they can more easily reallocate labour within the firm and they can spread the costs over a larger capital stock. However, small employers may be in a position to avoid many of those costs because in small production units labour is typically less organised (e.g. work

5. For the purposes of this document, the existing cross-country data on industry-specific product market regulations (see the papers in OECD, 2001a) were significantly extended to cover most of the energy and marketable service industries (a total of 21 industries and industry aggregates). Depending on the industry, the summary regulatory indicators cover barriers to entry, public ownership, price controls, government involvement in business operation, market concentration and vertical integration. In manufacturing, the industry-specific regulatory indicators cover only tariff and non-tariff barriers to trade. The indicators generally report the situation in the years 1995 to 1998 . For a subset of non-manufacturing industries, summary indicators cover a relatively long time-series of regulations. Details on data sources, methodologies and cross-country and crossindustry regulation patterns can be found in Annex 1.

6. The main difficulty that had to be overcome in empirical analysis is the lack of an industry dimension for policies and institutions of the labour market, which are generally uniform at the national level (apart from differences in sectoral union densities). This was tackled either by relying exclusively on the cross-country variability of labour market policies and institutions or by exploiting the interactions between these national indicators and industry characteristics, such as average firm size or use of high technologies.

7. Small firms also often make relatively intensive use of low-skilled labour perhaps due to diminishing costs per head as the pool of workers to be trained increases. 
councils are rarely present), collective dismissals (which are usually much more costly than individual ones) are less likely to occur and size thresholds for the application of EPL may apply. ${ }^{8}$ Therefore, the impact of EPL on the size distribution is largely an empirical issue.

14. Other labour market policies and institutions, such as minimum wages, taxation and administrative extension of collective agreements may also affect firm size. Minimum wages can be detrimental to small firms in the same way as wage floors imposed by certain centralised wage-bargaining systems. Administrative extension of collective agreements may also indirectly induce size distortions: as unionisation is usually less intensive in small firms, administrative extension may be more constraining on them. An important fiscal influence on size is likely to be the combination of corporate and income taxation systems, which can distort both the financing mix and investment choices (King and Fullerton, 1984) with repercussions on firm growth (Davis and Henrekson, 1999). On the other hand, payroll, social security and income taxes per se (summarised by the tax wedge on labour) are less likely to induce size distortions because they affect variable rather than fixed costs.

15. Here, the issue of the labour market determinants of firm size is addressed by studying the effects of wage bargaining mechanisms, tax wedges, administrative extension of collective agreements and EPL on the employment share of large enterprises in a panel of manufacturing, utilities and service industries across a large number of OECD countries. ${ }^{9}$ Consistent with previous studies in this field, wage bargaining mechanisms are described by means of the indicator of "corporatism". ${ }^{10}$ The model also investigates the potential interaction between economy-wide policies and industry-specific size effects originating from technology or market structure (represented by the average share of employment in large enterprises in the countries included in the sample). The underlying hypothesis is that the impact of such policies differs according to minimum efficient scale in the industry. ${ }^{11}$

8. The existence of formal employment thresholds for job protection policies or bargaining institutions may also directly distort the size distribution of firms by encouraging growth in output size rather than employment size, or the fragmentation of production units. For instance, in Italy firms with less than 15 employees (or less than 60 employees in firms whose establishments have less than 15 employees) are covered by a much smaller degree of EPL.

9. The role of minimum wages could not be checked in empirical analysis, due to limitations in data coverage. Statutory minima do not exist in many OECD countries, but they are often replaced by contractual minima, for which comparative data are not available.

10. This indicator combines both centralisation and co-ordination elements. There is a large literature on the different roles of centralisation and co-ordination in wage bargaining which mainly focuses on the effects on the level of wages and employment. Consistently, a corporatism index is obtained from these two measures that allows for an effect of co-ordination over and above centralisation only in countries with an intermediate level of centralisation (for details see Elmeskov et al., 1998).

11. When there are large economies of scale, the constraint imposed by regulation on size is likely to be less binding, since it is hard for small firms to survive even in the absence of these regulations. 
ECO/WKP(2001)38

Table 1. Policy and institutional indicators used in empirical analysis

\begin{tabular}{|c|c|c|c|c|c|c|}
\hline Indicator & Scale & Max & Min & Observations & Mean & $\begin{array}{l}\text { Coefficient of } \\
\text { variation }\end{array}$ \\
\hline \multicolumn{7}{|c|}{ Economy-wide product market regulation - 1998} \\
\hline Summary indicator & $0-6$ & $3.28(\mathrm{Pol})$ & 0.49 (Gbr) & 26 & 1.73 & 0.38 \\
\hline State control & $0-6$ & $4.25(\mathrm{Pol})$ & $0.55(\mathrm{Gbr})$ & 26 & 2.33 & 0.42 \\
\hline Involvement in business operation & $0-6$ & $4.50(\mathrm{Grc})$ & $0.46(\operatorname{Irl})$ & 26 & 2.27 & 0.43 \\
\hline Public ownership & $0-6$ & $5.07(\mathrm{Pol})$ & 0.03 (Gbr) & 26 & 2.39 & 0.52 \\
\hline Barriers to entrepreneurship & $0-6$ & 3.37 (Tur) & $0.48(\mathrm{Irl})$ & 26 & 1.75 & 0.42 \\
\hline Excess regulation on corporations ${ }^{1}$ & -6 to 6 & 2.0 (Grc, Esp) & $-2.5(\mathrm{Bel})$ & 26 & 0.15 & 6.47 \\
\hline Barriers to trade & $0-6$ & 4.18 (Cze) & 0.62 (Gbr) & 26 & 1.47 & 0.69 \\
\hline \multicolumn{7}{|c|}{ Time series of product market regulation ${ }^{2}-1978-98$} \\
\hline Summary indicator & $0-6$ & $6.00(78$, Fra $)$ & $1.02(98$, Gbr $)$ & 441 & 4.36 & 0.26 \\
\hline \multicolumn{7}{|l|}{ Industry-specific product market regulation } \\
\hline Summary indicator (ISIC 40-74) - 1998 & $0-1$ & & & & & \\
\hline Across countries & & $0.50(\mathrm{Pol})$ & 0.13 (Gbr) & 26 & & 0.27 \\
\hline Across industries & & 0.71 (Elec.) & 0.01 (Hotels, rest.) & 13 & & 0.89 \\
\hline Total & & $0.86($ Elec.*) & $\begin{array}{c}0.00 \text { (Sale, repair, } \\
\mathrm{W} / \text { sale,hotels, } \\
\left.\text { rest.,support trans. }{ }^{* *}\right)\end{array}$ & 292 & 0.25 & 0.97 \\
\hline Tariff barriers (ISIC 15-35) - 1996 & percentage & & & & & \\
\hline Across countries & & $28.1(\mathrm{Pol})$ & 4.35 (Jpn) & 26 & & 0.41 \\
\hline Across industries & & 60.4 (Tobacco) & 2.90 (Office machi.) & 21 & & 1.35 \\
\hline Total & & $\begin{array}{c}246.3 \\
(\text { Tobacco, Pol) }\end{array}$ & $0.00(* * *, J p n)$ & 546 & 10.08 & 1.79 \\
\hline Non-tariff barriers (ISIC 15-35) - 1996 & percentage & & & & & \\
\hline Across countries & & 16.6 (USA) & $0.00(\mathrm{Pol})$ & 26 & & 0.65 \\
\hline Across industries & & 59.0 (Textiles) & 0.00 (Tobacco) & 21 & & 2.38 \\
\hline Total & & 97.0 (Textiles, Prt) & $0.00(* * * *)$ & 546 & 7.28 & 2.98 \\
\hline \multicolumn{7}{|c|}{ Economy-wide labour market policies and institutions - 1996} \\
\hline Corporatism & $1-3$ & 3 (a) & $1(\mathrm{~d})$ & 26 & 2.04 & 0.43 \\
\hline Coordination & $1-3$ & $3(b)$ & $1(\mathrm{e})$ & 26 & 2.25 & 0.35 \\
\hline Centralisation & $1-3$ & $3(\mathrm{c})$ & $1(\mathrm{~d})$ & 26 & 1.81 & 0.38 \\
\hline Union density & percentage & $52.9(\mathrm{Bel})$ & 9.1 (Fra) & 9 & 25.0 & 0.50 \\
\hline EPL (individual dismissals) & $0-6$ & 3.7 (Prt) & 0.2 (Usa) & 22 & 2.15 & 0.51 \\
\hline EPL (collective dismissals) & Dummy & 1 & 0 & 19 & - & - \\
\hline Administrative extension & percentage & 85.9 (Fra) & -7.0 (Dnk) & 18 & 30.0 & 0.98 \\
\hline Tax wedge & percentage & 47.9 (Bel) & 9.6 (Kor) & 23 & 34.5 & 0.30 \\
\hline Gross replacement rates (average1993-97) & percentage & 69.4 (Dnk) & 5.2 (Ita) & 26 & 30.2 & 0.45 \\
\hline \multicolumn{7}{|l|}{ Industry-specific labour market institutions } \\
\hline Union density (ISIC 40-74) & percentage & & & & & \\
\hline Countries & & 70.1 (Swe) & 9.6 (Fra) & 11 & 34.5 & 0.52 \\
\hline Industries & & 61.5 (Comm.) & $\begin{array}{c}19.3 \text { (W/sale, retail, } \\
\text { hotel\&rest.) }\end{array}$ & 20 & 34.4 & 0.43 \\
\hline Total & & 100 ((f) Bel, Swe) & 1.7 (Finance, USA) & 180 & 33.9 & 0.74 \\
\hline
\end{tabular}

1. Difference between the indicators of strictness of administrative barriers on corporations and on the sole proprietor firms.

2. Summary of regulatory developments in seven service industries.

* Countries concerned : (41) AUT, CAN, DEU, FIN, KOR, NLD, NZL, POL.

** Countries concerned : (50-51) BEL, CHE, CZE, DEU, DNK, FRA, GBR, GRC, ITA, JPN, KOR, NLD, NOR, NZL, PRT, TUR, USA.

(55) AUS, AUT, BEL, CHE, CZE, DEU, ESP, FIN, FRA, GBR, GRC, HUN, IRL, JPN, KOR, NLD, NOR, NZL, PRT, SW (63) BEL, GBR, HUN, KOR, NLD.

*** Office machinery, Radio \& television, Motor vehicles, Other transport equipment.

**** In numerus cases.

(a) Countries concerned : AUT, CZE, DEU, DNK, GRC, IRL, ITA, NLD, NOR, POL.

(b) Countries concerned : AUT, CZE, DEU, DNK, GRC, IRL, ITA, JPN, KOR, NLD, NOR, POL.

(c) Countries concerned : CZE, ITA, NOR, POL.

(d) Countries concerned : AUS, CAN, CHE, GBR, JPN, KOR, NZL, TUR, USA.

(e) Countries concerned : CAN, GBR, NZL, TUR, USA.

(f) BEL : Electricity, Gas, Water ; SWE : Electricity, Gas, Water and construction. 
16. The analysis also controls for the effects of product market regulations, which can influence the size distribution of firms in various ways. Some regulations directly impose constraints on the number of firms in an industry (e.g. legal barriers to entry). Others induce costs that modify the number and the size of competing firms at the equilibrium (e.g. administrative burdens, trade barriers). Yet others affect the behaviour of firms (e.g. state control), with possible consequences on firm size. ${ }^{12}$ Effects originating from product market policies are estimated using the industry-specific and economy-wide indicators of regulations that restrict domestic and foreign competition (see Annex 1 and Table 1). Finally, the analysis controls for other factors that could explain differences in the size distribution of firms across countries and industries apart from labour and product market policies and institutions. Population accounts for possible country-specific effects of domestic market size. ${ }^{13}$ In manufacturing, where reliable industry and country-specific R\&D data are available, the possible correlation between innovation expenditure and firm size is accounted for. Industry and country dummies account for other possible industry and country-specific factors.

17. The focus is on the share of employment in firms with more than 50 employees because this variable has the best overall cross-country and cross-industry coverage. ${ }^{14}$ Regressions are performed using model specifications accounting for fixed-effects, clustering and random-effects, with the panel dimension given by countries (Box 1). The fixed-effect specification cannot account explicitly for determinants of size that lack the industry dimension, such as bargaining mechanisms or EPL, but provides a useful benchmark for assessing the robustness of the regression results. Details on model specification and regression results (including sensitivity analysis) can be found in Annex 2.

12. Indirect evidence on the effects of product market regulations on firm size is provided by Nicoletti et al. (2001) who find that self-employment shares tend to be higher in countries with relatively high administrative burdens on the start up of corporations.

13. Controlling for national market size is necessary due to the way data are constructed. In large countries, any multi-establishment firm is counted only once and its size is the sum of the size of all its establishments. Conversely, in small countries, when firms are large enough to have many establishments, they tend to diversify into neighbour countries. As a consequence, the size distribution of firms in large countries is not fully comparable with that of small countries, but this inconsistency might be overcome with a control for market size. Population is used here in order to avoid serious endogeneity problems.

14. Sensitivity analysis performed for non-manufacturing industries using other measures of size distribution (such as average employment size in firms with more than 10 employees, and average employment size in firms with more than 50 employees), suggests that the results are robust to different specifications of the share of large enterprises. 
ECO/WKP(2001)38

\section{Box 1. Estimation techniques for cross-country/time-series or cross-country/cross-industry data}

In cross-country/time-series regressions, units of observation (countries) are repeated over time. In crosscountry/cross-industry regressions, each data point (a country-industry couple) is a different unit of observation. However, in cross-country/cross-industry regressions, some variables may be defined only along the country or industry dimension (such as macroeconomic variables). Hence, these variables take the same value on clusters of observations. The use of OLS to estimate models with repeated units of observation or variables that take the same value on clusters of observations can yield biased and inconsistent estimates of coefficients and/or standard errors (Moulton, 1986).

In this paper, three estimating approaches are used to solve this problem: the fixed-effects estimator, in which the model is specified with dummies that control for repeated units or clusters of observations (e.g. country or industry fixed effects); the OLS estimator adjusted for clustering, which makes it possible to analyse the effects of variables that are constant on clusters of observations (such as variables that are uniform across industries); and the GLS random-effects estimator, in which the country-specific effects are assumed to be independently distributed random variables with mean zero and constant variance. To discriminate among these approaches, three tests are provided. A simple F-test is used to test the null hypothesis that there are no fixed effects specific to observation units (or clusters of observations). Rejection of the null implies that the simple linear model is incorrect and the OLS estimator with no adjustment is biased and spurious. The Breusch-Pagan test is applied to test the random-effects specification against the simple linear model with or without adjustment for clustering. Finally, the Hausman test verifies the hypothesis that the random effects are uncorrelated with the explanatory variables. If the test statistic is significant, the random-effects specification is incorrect and either a fixedeffects or a cluster-adjusted estimator is preferable. See Annex 2 for more details on these estimation techniques.

18. Table 2 summarises the results of panel regressions aimed at detecting effects of labour policies and institutions on the size distribution of firms. Given the very different nature of product market regulations in manufacturing and non-manufacturing industries, the analysis was performed separately for a panel of 18 countries and 18 manufacturing industries (Panel A), and for a panel of 16 countries and 12 utilities and service industries (Panel B). The reference period for the cross-section regressions is 19961998, depending on data availability. 
ECO/WKP(2001)38

Table 2. Policies, institutions and firm size

Results of panel regressions

Panel A. Manufacturing industries

Dependent variable: Employment share of large enterprises

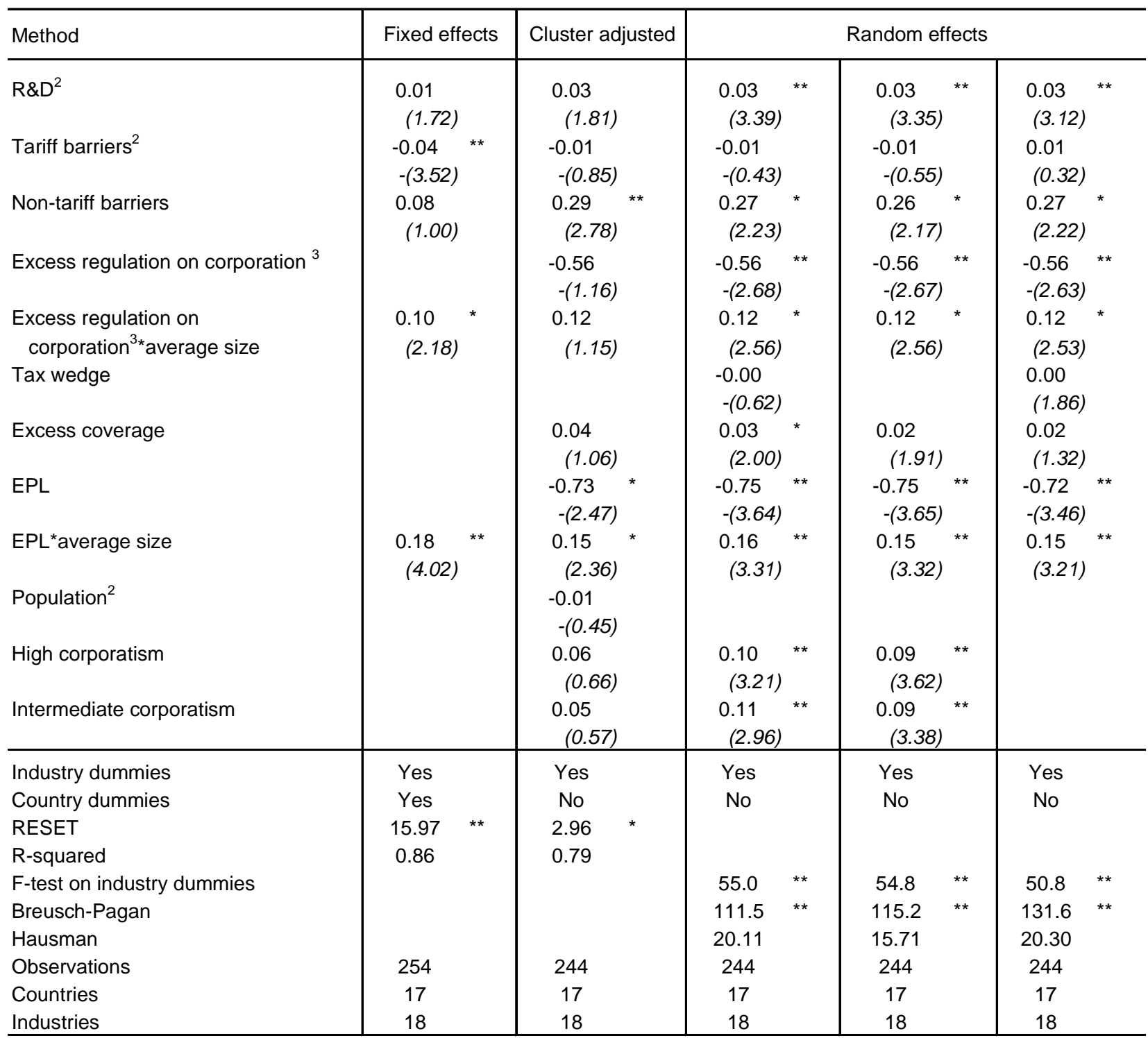

1. Logarithm of the share of firms with more than 50 employees in total employment of firms with more than 10 employees.

2. In logarithm.

3. Difference between the indicators of strictness of administrative barriers on corporations and on the sole-proprietor firms.

Note: All equations includes a constant. ${ }^{*},{ }^{* \star}$ denote significance at the $5 \%$ and $1 \%$ level, respectively.

T-statistics in parentheses.Samples are adjusted for outliers based on the Welsch distance cut-off

(Chatterjee and Hadi, 1988). 
Table 2. Policies, institutions and firm size (continued)

Results of panel regressions

Panel B. Non-manufacturing industries

Dependent variable: Employment share of large enterprises ${ }^{1}$

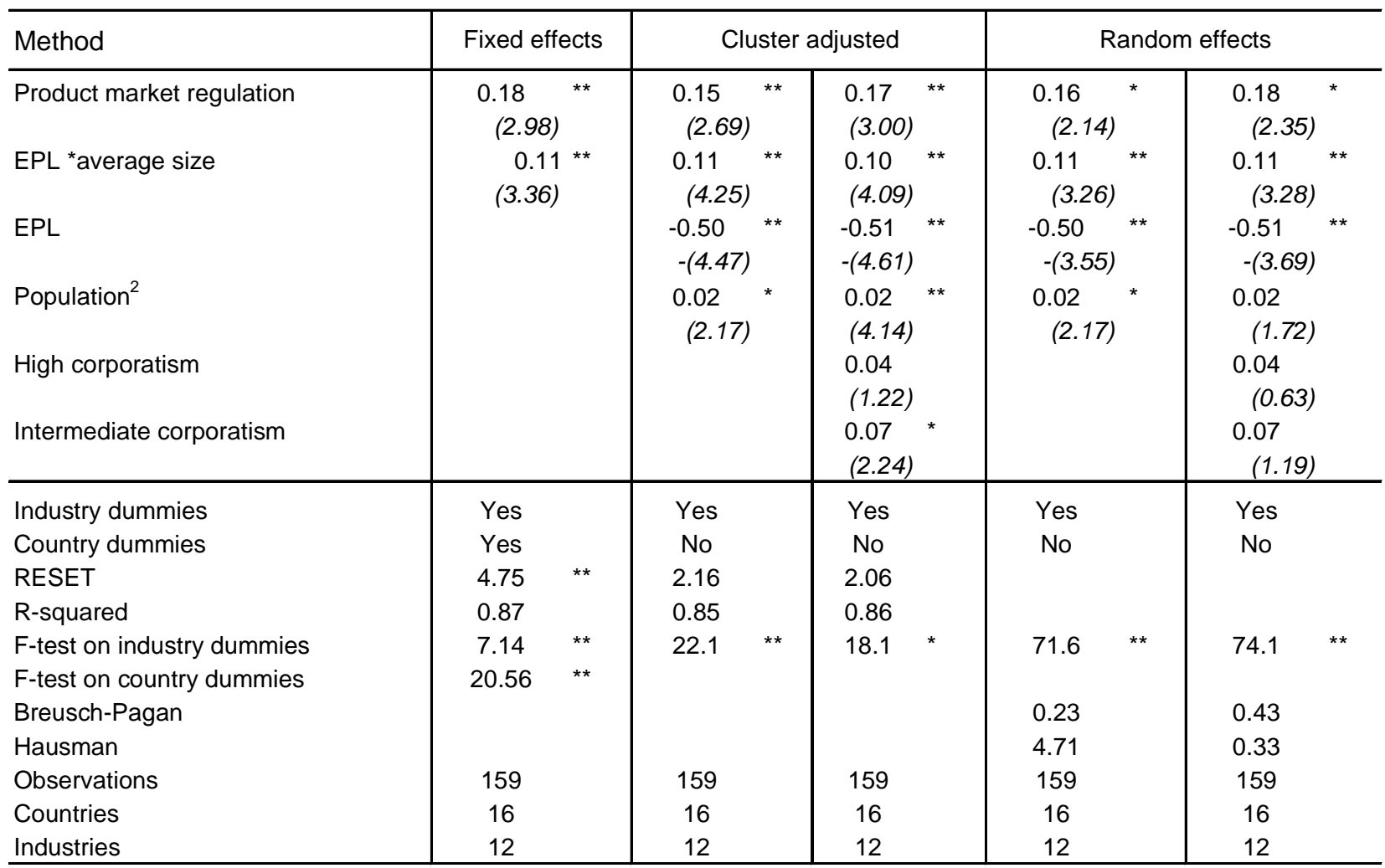

1. Logarithm of the share of firms with more than 50 employees in total employment of firms with more than 10 employees.

2. In logarithm

Note: All equations includes a constant. *, ${ }^{* \star}$ denote significance at the $5 \%$ and $1 \%$ level, respectively. T-statistics in parentheses. Samples are adjusted for outliers based on the Welsch distance cut-off (Chatterjee and Hadi, 1988). 


\section{$\mathrm{ECO} / \mathrm{WKP}(2001) 38$}

19. The findings for the two sets of industries are broadly consistent and are robust to changes in the definition of the dependent variable (see Annex 2). The results of the specification tests suggest that, in both manufacturing and non-manufacturing industries, the cluster-adjusted and random-effects models, which explicitly take into account economy-wide policy and institutional variables, are to be preferred. ${ }^{15}$ The sign and significance of coefficient estimates is generally consistent across all model specifications, save for the estimates concerning tariff and non-tariff barriers (in manufacturing industries) whose precision changes significantly moving from fixed to random-effects specifications. Interaction terms are generally significant, but their coefficient estimates are fully interpretable only in conjunction with the estimates of the direct effects of policies. ${ }^{16}$

20. The regression results suggest several conclusions:

- Policies and institutions significantly contribute to explain the cross-country and crossindustry differences in the employment share of large enterprises over and above the effects of other industry and country characteristics.

- The net effect of EPL is to reduce the employment share of large firms. In all model specifications, EPL has a significant and negative effect on this share. However, this effect tends to disappear in industries characterised by important economies of scale (utilities, post and telecommunications, air transport, financial intermediation). Table 3 shows the estimated net effect of EPL on this share once the interaction of EPL with structural differences in firm size across industries is accounted for. While, on average, the net effect is to reduce firm size, no such effect can be detected in utilities, air transport, telecommunications and banking, all highly capital-intensive service industries.

- Co-ordination and centralisation of bargaining systems tend to increase the employment share of large firms in manufacturing industries. In these industries, dummies identifying countries with high or intermediate levels of corporatism, a summary measure of co-ordination and centralisation of wage bargaining, generally have a significant and positive effect on firm size.

- There is some weak evidence that administrative extension of collective agreements tends to increase average firm size. Administrative extension of collective agreements, has a positive and sometimes significant effect on the share of large manufacturing enterprises.

- There is no evidence that taxes tend to raise the average size of firms. Neither overall tax wedges nor employer social security contributions (not shown in the table) are associated with the share of large enterprises in the economy.

15. Throughout the paper, specification is checked by means of the following sequence of tests: the RESET test for general misspecification, the F-test for the joint significance of the fixed country effects, the F-test of joint significance of industry dummies, the Breusch-Pagan test for the existence of random effects and the Hausman test for the appropriateness of the random-effects specification (see Box 2).

16. As a general rule, interaction terms are introduced whenever a variable that has only one of the panel dimension is not expected to have a uniform effect across the whole sample. In the regressions whose results are presented in Table 2, excess administrative burdens on corporations (relative to sole-proprietor firms) and EPL are assumed to have a different impact on size according to the importance of scale economies in each given sector (summarised by the average firm size across countries). Subject to this hypothetical functional form, the derived coefficient for any particular industry can be obtained as the sum of the coefficient of the level of the policy variable plus the coefficient of the corresponding interaction term times the average firm size for that particular industry. Table 3 groups different industries according to sign and significance of the derived estimated coefficients. 
- On the whole, product market regulations that restrict competition tend to be associated with a higher share of employment in large enterprises. In utilities and service industries, industryspecific regulations (as measured by the summary product market indicators) unambiguously increase this share. In manufacturing, industry-specific non-tariff barriers have a significant and positive effect on the share of large enterprises, while this share decreases as administrative procedures on the start-up of corporations become more burdensome relative to sole-proprietor enterprises (Table 3). ${ }^{17}$ Thus, both the overall degree of product market restrictions and the distortions induced by differences in administrative burdens for different classes of enterprises affect the size distribution of firms.

Table 3. Net effect of policies and institutions on the share of large enterprises (by industry)

\begin{tabular}{|c|c|c|c|}
\hline & $\begin{array}{c}\text { EPL } \\
\text { Manufacturing }\end{array}$ & $\begin{array}{c}\text { EPL } \\
\text { Non-Manufacturing }\end{array}$ & $\begin{array}{l}\text { Excess regulation on } \\
\text { corporation }^{1} \\
\text { Manufacturing }\end{array}$ \\
\hline $\begin{array}{c}\text { Significantly } \\
\text { negative }^{2}\end{array}$ & All industries & $\begin{array}{c}\text { Wholesale, Retail trade, Repair } \\
\text { Hotels, Restaurants } \\
\text { Land transport } \\
\text { Water transport } \\
\text { Auxiliary transport activities } \\
\text { Other business services }\end{array}$ & $\begin{array}{c}\text { Food, Beverages, Tobacco } \\
\text { Textiles, Fur, Leather } \\
\text { Wood, Cork } \\
\text { Pulp, Paper, Paper product } \\
\text { Printing, Publishing } \\
\text { Coke, Petrol } \\
\text { Chemicals } \\
\text { Ruber, Plastics products } \\
\text { Non-metallic mineral prod. } \\
\text { Fabricated metal product } \\
\text { Machinery and Eq., n.e.c } \\
\text { Office machinery } \\
\text { Electrical machinery, n.e.c } \\
\text { Instruments, Watches, Clocks }\end{array}$ \\
\hline $\begin{array}{c}\text { Significantly } \\
\text { positive }^{2}\end{array}$ & None & None & None \\
\hline Insignificant & None & $\begin{array}{c}\text { Electricity, Gas and Water } \\
\text { Air transport } \\
\text { Post, Communications } \\
\text { Financial intermediation }\end{array}$ & $\begin{array}{c}\text { Basic metals } \\
\text { Radio, television } \\
\text { Motor vehicles } \\
\text { Other transport eq., n.e.c }\end{array}$ \\
\hline $\begin{array}{l}\text { Average of all } \\
\text { industries }\end{array}$ & $\begin{array}{l}-0.06 * * \\
(5.26)\end{array}$ & $\begin{array}{l}-0.04 * * \\
(3.94)\end{array}$ & $\begin{array}{l}-0.03^{* *} \\
(3.39)\end{array}$ \\
\hline
\end{tabular}

1. Difference between the indicators of strictness of administrative barriers on corporations and on the sole proprietor firms.

2. Significant at the $5 \%$ level.

Notes: The table shows industries grouped according to the significance of the impact of the policy variable. Derived from Table 2, Panel A, Column 3 and Panel B, Column 3. t-statistics in parentheses. ** denotes significance at $1 \%$ level.

17. The size distortion induced by administrative burdens tends to be weaker in industries structurally characterised by a relatively larger firm size because, in the presence of a large minimum efficiency scale, there are fewer opportunities for choosing firm size. There is also some evidence from the fixed-effects model that tariff barriers may be associated with a smaller share of large firms, perhaps reflecting the cost advantage they implicitly provide to small incumbents relative to larger foreign suppliers. However, this effect disappears in randomeffects regressions that include economy-wide regulations. 
21. Institutions and policies can also affect the size distribution of firms without altering significantly the average size of firms or the share of large firms. For instance, thresholds in the application of certain regulatory provisions may modify the incentives concerning the choice of size by firms that would be otherwise in the neighbourhood of those thresholds. Table 4 explores the role of differences in the definition of collective dismissals across countries by checking whether relatively low thresholds are associated with "anomalies" in the size distribution of small firms. To this end, the average size of firms in the 10 to 50 employees dimensional class was regressed on average firm size (in firms with more than 10 employees) and a dummy variable identifying the countries where compliance with collective dismissals regulations is required at particularly low dismissal thresholds. ${ }^{18}$

Table 4. Definition of collective dismissals and firm size

Manufacturing industries

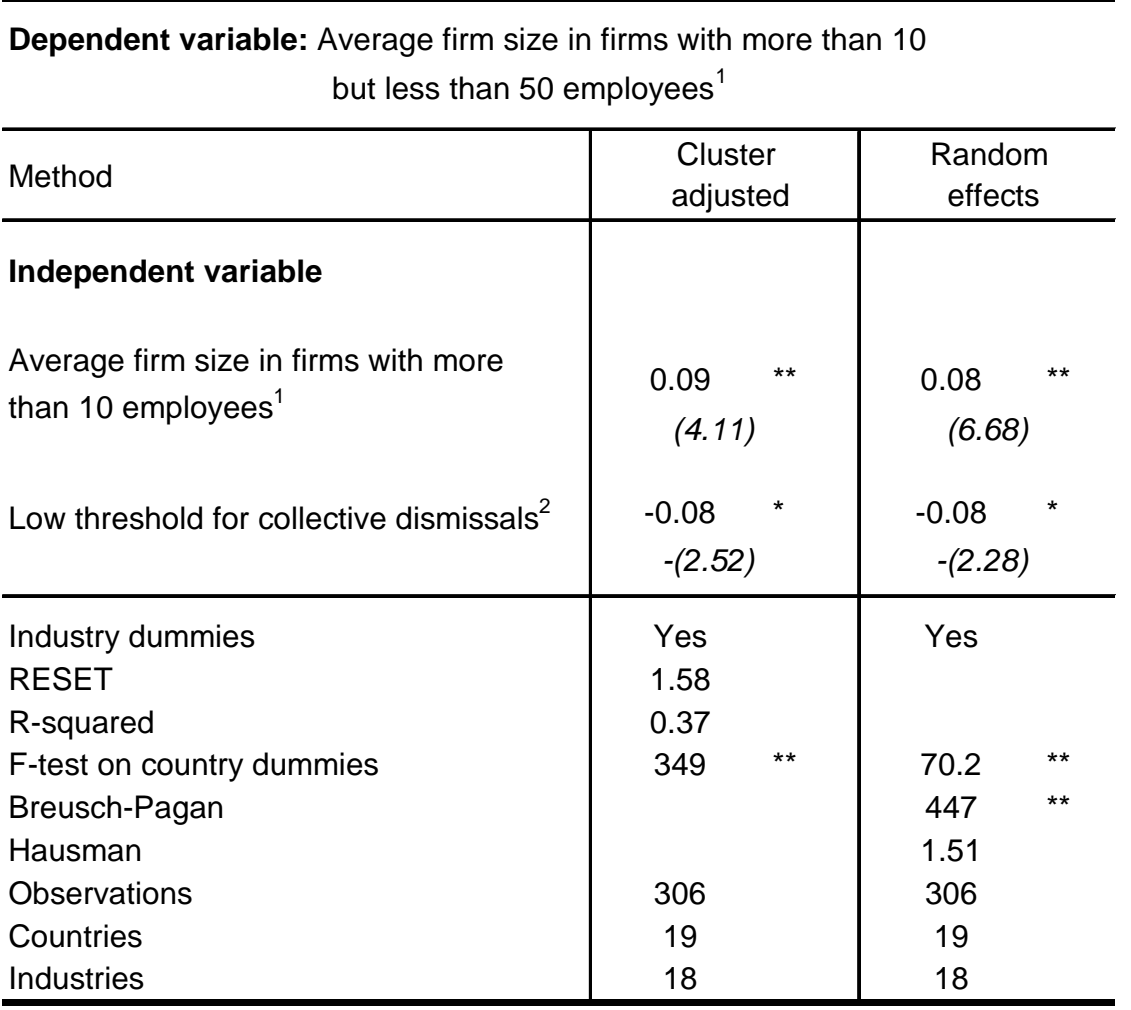

1. In logarithm.

2. Dummy variable identifying countries where collective dismissals are defined at below 10 dismissals.

Note: All equations includes a constant. *, ${ }^{* *}$ denote significance at the $5 \%$, and $1 \%$ level, respectively. T-statistics in parentheses. Samples are adjusted for outliers based on the Welsch distance cut-off (Chatterjee and Hadi, 1988).

18. These countries are Austria, the Czech Republic, Germany, Greece, Italy and Portugal, where collective dismissals are defined at below ten dismissals (see Watson Wyatt, 1997; and OECD, 1999c). The assumption behind the regressions is that, if one country has a low average size of firms, it is expected to have a low average size also in the class of firms with 10-50 employees. Departures from this pattern depend on factors that twist the distribution in this class, without affecting significantly either the average size or the share of large firms. 
22. The results provide some evidence that strict definitions of collective dismissals may twist the firm size distribution away from "normal" convex patterns (Sutton, 1998), inducing smaller average size in the 10-50 employees class than would be expected based on overall average firm size. A particularly small size within this class may be a reflection of entrepreneurs' attempt to escape the potential costs associated with collective dismissal procedures by keeping a number of employees that makes it unlikely to incur in those procedures. ${ }^{19}$

\section{Conclusions on firm size}

23. These empirical findings throw some light on the influence of labour market policies and institutions on the size distribution of firms in OECD countries. The idea that corporatist wage-bargaining systems may favour large employers by leading to a compressed wage structure receives some limited cross-country empirical support. The hypothesis that strict EPL regimes may twist downwards the size distribution of firms is more clearly supported by regression analysis, especially when stability of demand and economies of scale (leading to lower EPL costs per unit of output and an easier within-firm reallocation of labour) are lacking. Indeed, the regression results suggest that economies of scale must be very large, such as in utilities, to compensate for the negative effects of EPL on firm size. Moreover, there is some suggestive evidence that threshold effects can significantly affect the size distribution of firms, when overall employment levels are sufficiently small to make collective dismissal procedures costly.

\subsection{Innovation}

24. The economic analysis of the determinants of innovation has focused mostly on the relationship between incentives to innovate and product market competition (e.g. Dasgupta and Stiglitz, 1980; Nelson and Winter, 1982; Schmalensee, 1989; Nickell, 1996; Aghion and Howitt, 1998; and Boone, 2000b). From an empirical point of view, recent evidence suggests a positive relationship between product market competition and innovation, at each given level of protection of intellectual property rights (Geroski, 1990; Nickell, 1996; Blundell et al., 1995, 1999). Conversely, Aghion et al. (2001b) present firm-level and cross-country evidence that support a hump-shaped relationship between competition and innovation (proxied by patent performance). ${ }^{20}$

25. Labour market arrangements too may affect the propensity of an economy to innovate (see e.g. Soskice, 1997; Eichengreen and Iversen, 1999; Acemoglu and Pischke, 1999b, Bassanini and Ernst, 2001). The most likely labour market influences on innovation come from hiring and firing rules and the industrial relations regime, though minimum wages and the generosity of unemployment insurance can also play a role via their impact on wage structure and workers' bargaining power and attitude towards risk (Acemoglu and Pischke, 1999c; Acemoglu, 2000). For instance, restrictive EPL can curb innovation rents by hindering labour adjustments, which often occur after incumbent firms have implemented innovations (see e.g. Audretsch and Thurik, 2001; Caroli et al., 2001; Hobjin and Jovanovic, 2001). Labour market arrangements that favour the sharing of innovation rents, for instance by increasing the bargaining power of insiders or tying negotiations to enterprise performance, also may inhibit innovative activity by reducing the expected returns from innovations.

26. Hiring and firing rules and industrial relations regimes can have independent effects on innovation activity, but the intensity (and perhaps even the sign) of this effect is likely to depend on the way these policies and institutions interact with each other. For instance, important effects on innovation may come from the way EPL and industrial relations regimes affect the quality and the availability of skilled labour, which is often seen

19. For a firm of less than 50 employees, resorting to 5-10 dismissals in its near future is an event with a nonnegligible probability. Conversely, for the same firm, the probability of incurring a collective dismissal is very low when the latter is defined at more than 10 employees.

20. Perfect competition makes firms indifferent vis-à-vis the choice whether to innovate or not, but the possibility to appropriate rents coupled with competitive struggle makes innovation desirable. When rent protection becomes strong enough, incentives to innovate fade out again. Therefore, if a market moves from monopoly to perfect competition, innovative activity first increases and then decreases. 


\section{$\mathrm{ECO} / \mathrm{WKP}(2001) 38$}

as a complementary input to new technologies. If technological change is skill-biased, incumbent firms need to shift from one optimal skill mix to another in order to implement an innovation effectively. Essentially, two strategies are open to the successfully innovating incumbent: either it trains its existing workforce or it lays-off part of its staff and hires more skilled workers, possibly "poaching" other firms' pools of skilled labour. Restrictive EPL and highly co-ordinated industrial relations regimes generally encourage firms to resort to internal labour reallocations and undertake firm-sponsored training. This is because in such regimes job turnover is impaired (Bertola, 1992), the ties between workers and their employers often inhibit poaching, ${ }^{22}$ and firms can reap the difference between the marginal productivity of skilled workers and their earnings, due to wage compression over the skill dimension (Acemoglu and Pischke, 1998, 1999a, 1999b). ${ }^{23}$ Conversely, lax EPL and decentralised industrial relations regimes raise job turnover and tend to increase wage dispersion and skill premia. This discourages firm-sponsored training and leads firms to acquire the necessary skilled workers on the external labour market. Therefore, given the complementarity between innovation and skills at the firm level, each combination of EPL and industrial relations regimes may lead to specific propensities of industries to innovate, national industry specialisation and, ultimately, economy-wide innovation potentials.

27. Since both product and labour market influences can act in opposite directions, their net effects on innovation are controversial and can only be assessed empirically. Following Bassanini and Ernst (2001), this section develops a cross-country econometric analysis of the linkages between policies, institutions and innovation patterns, making use of the industry dimension where available. Both the country and industry dimensions are important because labour market arrangements differ mainly across countries, but links between institutions and performance might be radically different in different industries. For instance, in low-tech industries, where elasticities of demand are generally low (at the industry level), innovation is mainly aimed at cutting costs rather than expanding capacity, often resulting in lay-offs. Hence, in these industries, firing restrictions are more likely to reduce innovation activity than in high-tech industries. The use of the industry dimension also makes it possible to control for differences in technological opportunity among different sectors.

28. The analysis at the industry level covers only the manufacturing sector, given the dearth and low quality of data concerning innovation activity for the non-manufacturing industries. Furthermore, the focus is mainly on $R \& D$ intensity, since it is the only available variable that is comparable across countries and industries simultaneously. R\&D expenditure is at best an indicator of innovation input rather than of innovation output (see Annex 1). For this reason, the analysis also looks at the influence from policies and institutions on patenting and the intensity of expenditure on information technologies (IT), though only at the aggregate level since no industry disaggregation is available for these variables on a cross-country basis. ${ }^{24}$

21. Existing empirical evidence on poaching reports that that there are wage gains to switching jobs in the US (Topel and Ward, 1992; McCue, 1996) but not in Germany (Zimmermann, 1998). Furthermore, Blinder and Krueger (1996) report that inter-firm job mobility in Japan is virtually non-existent due to customary practices of firms. Conversely, they report that many Japanese multinational firms have been forced to revise training strategies in their American affiliates shortly after their establishment, due to poaching by other firms.

22. Recent research (for a survey, see Acemoglu and Pischke, 1999b) suggests that poaching may be inhibited by several factors: (i) centralised and/or co-ordinated wage bargaining settings may extend contracts and/or customary practices to cover almost all firms and workers; (ii) information may be lacking on previous training of job candidates; (iii) frictions and search costs may be high; (iv) skills may be partly firm-specific; (v) lay-offs and quits may suffer from adverse selection.

23. Incentives to undergo firm-sponsored training exist only if the difference between the productivity of workers and the wages paid by the firm is greater in the case of skilled workers rather than unskilled workers. Lynch (1994), Blinder and Krueger (1996), Soskice (1997), Acemoglu and Pischke (1999a, 1999b) and OECD (1993 and 2000c) report evidence of higher firm-sponsored training in more co-ordinated countries. Consistently, Davis (1992), Blau and Kahn (1996), Blinder and Krueger (1996), Gottschalk and Smeeding (1997), OECD (1997a) and Kahn (1998) report evidence linking a compressed wage structure to centralisation/co-ordination of wage-bargaining systems.

24. Other important features of innovation, which are ignored here, are science-industry links, co-operation between firms and financial market arrangements (e.g. venture capital). See OECD (2000d). 
29. Table 5 reports the results of cross-country regressions relating business-sector R\&D intensity, patents per capita and IT intensity to indicators of product and labour market policies and institutions. Given the relatively few degrees of freedom available and the absence of adequate controls, these regressions should be interpreted as exploratory data analysis aimed at identifying the policy and institutional covariates of innovation. The cross-country estimates show no obvious relationship between product market regulations and the measures of business-sector innovative activity. There is no overall correlation between these measures and the summary regulatory indicator (not shown in the table) because its main components relate to it in opposite ways: in most regressions, R\&D intensity, IT adoption and patenting are decreasing in the degree of state control, but increasing in the extent of barriers to entrepreneurship (except in the case of IT adoption). ${ }^{25}$ At the same time no association with trade barriers can be detected at this level of aggregation. The estimates suggest that R\&D intensity is related to EPL and centralisation or co-ordination of wage bargaining in opposite ways. It is decreasing in the severity of job protection and increasing in centralisation or co-ordination.

Table 5. Aggregate relationships between policies, institutions and innovation Cross-country OLS regressions

\begin{tabular}{|c|c|c|c|c|c|c|c|c|c|}
\hline \multirow{3}{*}{$\begin{array}{l}\text { Dependent variable: } \\
\text { Independent variables }\end{array}$} & \multicolumn{3}{|c|}{ R\&D intensity ${ }^{1}$} & \multicolumn{3}{|c|}{ IT adoption ${ }^{2}$} & \multicolumn{3}{|c|}{ Patenting $^{3}$} \\
\hline & $\begin{array}{c}\text { Product } \\
\text { market } \\
\text { regulation }\end{array}$ & \multicolumn{2}{|c|}{$\begin{array}{l}\text { Product and labour } \\
\text { market regulation }\end{array}$} & \multirow[t]{2}{*}{ 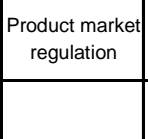 } & \multicolumn{2}{|c|}{$\begin{array}{l}\text { Product and labour } \\
\text { market regulation }\end{array}$} & $\begin{array}{c}\text { Product market } \\
\text { regulation }\end{array}$ & \multicolumn{2}{|c|}{$\begin{array}{l}\text { Product and labour } \\
\text { market regulation }\end{array}$} \\
\hline & & & & & & & \multirow{7}{*}{$\begin{array}{l}-0.91 \\
-(2.06) \\
0.27 \\
(0.53) \\
-0.69 \\
-(1.61)\end{array}$} & & \\
\hline State control & $\begin{array}{l}-0.66 \quad \text { ** } \\
-(3.52)\end{array}$ & $\begin{array}{l}-0.99 \text { ** } \\
-(5.43)\end{array}$ & $\begin{array}{l}-0.61 \quad \text { ** } \\
-(3.82)\end{array}$ & \multirow{6}{*}{$\begin{array}{l}-0.29 * \\
-(2.45) \\
-0.22 \\
-(1.55) \\
0.01 \\
(0.11)\end{array}$} & $\begin{array}{l}-0.41 \quad \text { ** } \\
-(3.02)\end{array}$ & $\begin{array}{l}-0.22 \\
-(1.84)\end{array}$ & & $\begin{array}{l}-2.11 \quad \text { ** } \\
-(3.91)\end{array}$ & $\begin{array}{l}-1.36 \text { ** } \\
-(3.00)\end{array}$ \\
\hline Barriers to entrepreneurship & $\begin{array}{l}0.38 \\
(1.70)\end{array}$ & $\begin{array}{l}0.93 \\
(4.34)\end{array}$ & $\begin{array}{l}0.61 \\
(2.83)\end{array}$ & & $\begin{array}{l}0.09 \\
(0.54)\end{array}$ & $\begin{array}{l}-0.07 \\
-(0.44)\end{array}$ & & $\begin{array}{l}1.30 \\
(2.05)\end{array}$ & $\begin{array}{l}0.67 \\
(1.09)\end{array}$ \\
\hline Trade barriers & $\begin{array}{l}0.08 \\
(0.41)\end{array}$ & & & & & & & & \\
\hline EPL & & $\begin{array}{l}-0.40 \text { * } \\
-(2.50)\end{array}$ & $\begin{array}{l}-0.41 \text { * } \\
-(2.24)\end{array}$ & & $\begin{array}{l}-0.26 \text { * } \\
-(2.20)\end{array}$ & $\begin{array}{l}-0.23 \\
-(1.73)\end{array}$ & & $\begin{array}{l}-0.48 \\
-(1.00)\end{array}$ & $\begin{array}{l}-0.47 \\
-(0.90)\end{array}$ \\
\hline Coordination of wage bargaining & & & $\begin{array}{l}0.566^{\star \star} \\
(3.19)\end{array}$ & & & $\begin{array}{l}0.13 \\
(0.98)\end{array}$ & & & $\begin{array}{l}0.99 \quad * \\
(1.99)\end{array}$ \\
\hline Centralisation of wage bargaining & & $\begin{array}{l}1.00 \text { ** } \\
(4.19)\end{array}$ & & & $\begin{array}{l}0.44 \text { * } \\
(2.50)\end{array}$ & & & $\begin{array}{l}1.922^{* *} \\
(2.73)\end{array}$ & \\
\hline Jarque-Bera & 1.50 & 1.76 & 0.59 & 0.39 & 0.22 & 0.52 & 2.92 & 2.69 & 1.18 \\
\hline $\mathrm{R}^{2}$ & 0.40 & 0.69 & 0.62 & 0.42 & 0.59 & 0.50 & 0.39 & 0.50 & 0.43 \\
\hline $\mathrm{R}^{2-}$ adjusted & 0.32 & 0.64 & 0.55 & 0.34 & 0.54 & 0.43 & 0.31 & 0.40 & 0.32 \\
\hline Observations & 26 & 26 & 26 & 26 & 26 & 26 & 26 & 26 & 26 \\
\hline
\end{tabular}

1. Logarithm of the ratio of business expenditure in R\&D to GDP.

2. Logarithm of the ratio of expenditure in information technology to GDP.

3. Logarithm of patents per capita.

Note: All equations includes a constant. *, ${ }^{* \star}$ denote significance at the $5 \%$ and $1 \%$ level, respectively. T-statistics in parentheses.

The sample includes all OECD countries except Iceland, Luxembourg, Mexico and Slovak Republic.

30. To further explore the possible interactions between EPL and industrial relations, a proxy for coordination of industrial relations (as opposed to bargaining) regimes was related to the three measures of innovation activity. To suit the analysis of innovation, the proxy for industrial relations regimes takes into account both the centralisation and co-ordination dimensions and, henceforth, in this section industrial relations regimes are said to be co-ordinated when bargaining is either co-ordinated, centralised or both, and de-

25. The positive correlation with barriers to entrepreneurship could be related to the Schumpeterian rent appropriability argument according to which competition is negatively related to innovation since postinnovation rents should be high enough to cover the cost of innovation. Bassanini and Ernst (2001) show indeed that this effect disappears when controlling for IPRs. The negative correlation with state control could be related to competitive slack in economies with high public interference in the business sector. 


\section{$\mathrm{ECO} / \mathrm{WKP}(2001) 38$}

centralised when bargaining is neither centralised nor co-ordinated. ${ }^{26}$ The aim is to capture the repercussions of industrial relations regimes on innovation through their effect on wage structures and firm strategies for upgrading skills (such as resort to external or internal labour markets, poaching skills of competitors, etc.). On the one hand, a high level of co-ordination of business associations and the code of conduct between firms tends to make the poaching of skills less likely; on the other hand, both bargaining centralisation and co-ordination tend to compress wage structures. Figure 1 bundles the business-sector R\&D intensities of countries in the sample into four subgroups, depending on whether they have lax EPL/low co-ordination in industrial relations, strict EPL/low co-ordination, lax EPL/high co-ordination or strict EPL/high co-ordination. ${ }^{27}$ The figure suggests that there is an interaction between EPL and co-ordination in industrial relations for both patents and, to a lesser extent, R\&D intensity, with the highest performances corresponding to polarised regimes, while no interaction is suggested for IT. ${ }^{28}$

31. The evidence found at the aggregate level can be better explored in panel regressions combining the country and industry dimensions. Table 6 presents estimates of the determinants of R\&D intensity obtained using fixed-effects, cluster-adjusted and random-effects estimators (see Box 1) in a sample of 18 manufacturing industries and 18 OECD countries. The estimated models account for the effects of EPL, industrial relations regimes and their potential interactions, but control also for outward and inward-oriented product market regulations (at both the industry and economy-wide levels). In addition, they control for firm size (the share of employment in large enterprises) and trade openness (proxied by import penetration). ${ }^{29}$ In view of the potential endogeneity between firm size and $R \& D$ highlighted by the results of the firm size regressions, it is important to stress that all the results described below are essentially robust to the elimination of the control for firm size from the estimated model specification. All regressions also include industry dummies to control for unexplained industry characteristics (e.g. technological opportunity). Finally, the potential interaction between EPL, industrial relations regimes and the technological characteristics of different industries was dealt with by introducing a dummy variable that identifies high-technology industries, defined according to the standard OECD classification. ${ }^{30,31}$

26. Due to data limitations, this measure is constructed only on the basis of available indexes of centralisation and co-ordination of wage-bargaining. The indicator of corporatism suggested by Elmeskov et al. (1998), among others, also accounts for both co-ordination and centralisation of wage bargaining. However, this indicator of corporatism is not appropriate in this context because it classifies countries such as Japan and Korea as being decentralised, while they are characterised by a high level of co-ordination in industrial relations. It should be stressed, in any case, that the indicator adopted in this section is itself a rough proxy of a very complex and multifaceted phenomenon.

27. For illustrative purposes low and intermediate co-ordination countries are grouped together in this figure.

28. IT intensity can be seen as a proxy for technology adoption and organisational change, rather than innovation. Organisational change is more frequent than innovation in low-tech industries, often leading to downsizing (Caroli et al., 2001). Therefore it is not surprising that fire restrictions seem to have a more negative impact on IT intensity than on other indicators of innovation performance.

29. Firm size is often found to correlate with R\&D intensity, but the direction of causation is unclear. This link may simply be the outcome of different accounting practices between large and small firms (Griliches, 1990), but it could also reflect the fact that successful innovation typically leads to larger firm size (Dasgupta and Stiglitz, 1980; Levin and Reiss, 1984; and Sutton, 1998). The employment share of affiliates of foreign firms and the share of business R\&D financed by the government were also used as controls, but they were omitted from the tables because they had no significance and no bearing for the other coefficient estimates.

30. Hatzichronoglou (1997) classifies industries in four groups: low-tech, medium/low-tech, medium/high-tech and high-tech. However, in this regression, differences in coefficients between the former two or between the latter two have not been found to be statistically significant.

31. Specifications including the generosity of the unemployment insurance systems (alone and in interaction with EPL) were also estimated. However, the coefficients of these variables were insignificant and their inclusion had no bearing for the other coefficient estimates. See Annex 2 for details. 
32. Consistent with previous evidence, R\&D intensity is positively associated with the share of large firms; it also increases with trade openness, perhaps pointing to the existence of positive knowledge spillovers. ${ }^{32}$ Among product market regulations, non-tariff barriers, state control and barriers to entrepreneurship are the most significant, with non-tariff barriers negatively affecting R\&D and state control and barriers to entrepreneurship having opposite effects on R\&D, confirming the results found in the aggregate regressions. ${ }^{33}$

33. EPL and co-ordination in industrial relations have significant effects on R\&D intensity, and their signs are consistent with those found in the aggregate regressions. ${ }^{34}$ Ceteris paribus, $R \& D$ appears to decrease with the stringency of EPL and to increase with the degree of co-ordination. At the same time, no effect on $\mathrm{R} \& \mathrm{D}$ of the interaction between EPL and co-ordination in industrial relations can be found pooling all industries together. Results change, however, if separate coefficients for high and low-technology industries are estimated, suggesting that pooling may be inappropriate to gauge the effects of interactions between EPL and co-ordination on R\&D. While the estimates for control variables and product market regulations do not change, interaction terms now have significant and opposite effects on the two sets of industries. At any given level of EPL and coordination in industrial relations, their combination appears to have a positive effect on R\&D intensity in hightech industries and a negative effect in low-tech industries. Co-ordination tends to partly offset the negative influence of EPL in high-tech industries, perhaps due to the fact that EPL is less binding for innovative activity when firms resort to the internal labour market. As mentioned above, this is less likely to occur in industries with low elasticities of demand, partly explaining the negative effect found in low-tech industries.

34. To throw further light on this issue, an alternative specification was tested in which the effects of EPL differ according to the three levels of co-ordination, relaxing the hypothesis of linearity of co-ordination effects. The aim of this specification, which is preferred by model specification tests over the linear one,$^{35}$ is to sort out situations in which policy-makers who wish to change EPL policies should worry about the possible effects of these policy changes on innovation performance, taking as given the existing regime of industrial relations. The estimated net effects on R\&D of EPL and co-ordination in industrial relations are described in Table 7. Clearly, the Table provides information only on the impact on innovation activity of differences in EPL (co-ordination) given the level of co-ordination in industrial relations (EPL). The analysis has no bearing for the effect on innovation of simultaneous changes in EPL and co-ordination in industrial relations nor, for that matter, for the relative levels of innovation in two economies characterised by different combinations of EPL and coordination.

32. Trade openness increases product variety in domestic markets and induces imitation by domestic producers. Imitation requires spending in R\&D (Cohen and Levinthal, 1989).

33. High non-tariff barriers are likely to affect the elasticity of substitution between imported and domestically produced products, thereby lowering incentives to innovate when domestic and foreign firms have similar levels of competitiveness (the case of "neck and neck" competition, see Aghion et al. 1997, 2001a; and Boone, 2000b).

34. All the regression results contained in the table are essentially robust to alternative measures of coordination/centralisation such as the indicator of the degree of corporatism and the indicator of the level of centralisation in wage bargaining.

35. The alternative model was specified by introducing dummies for high and intermediate co-ordination. Interaction terms have thus been specified accordingly (EPL in high-co-ordination countries, EPL in intermediate-coordination countries, EPL in low-co-ordination countries. A standard F-statistic rejected the null of the linear model against the non-linear alternative. To check the robustness of this result, the non-nested testing procedure of Davidson and McKinnon (1981) was used to test the null of the non-linear model against the linear alternative, resulting in a non-rejection. See Annex 2 for details. 
Figure 1. Labour market regimes and innovation

$\square$ Low EPL Low Coor

$\square$ High EPL Low Coor

$\square$ Low EPL High Coor

$\square$ High EPL High Coor
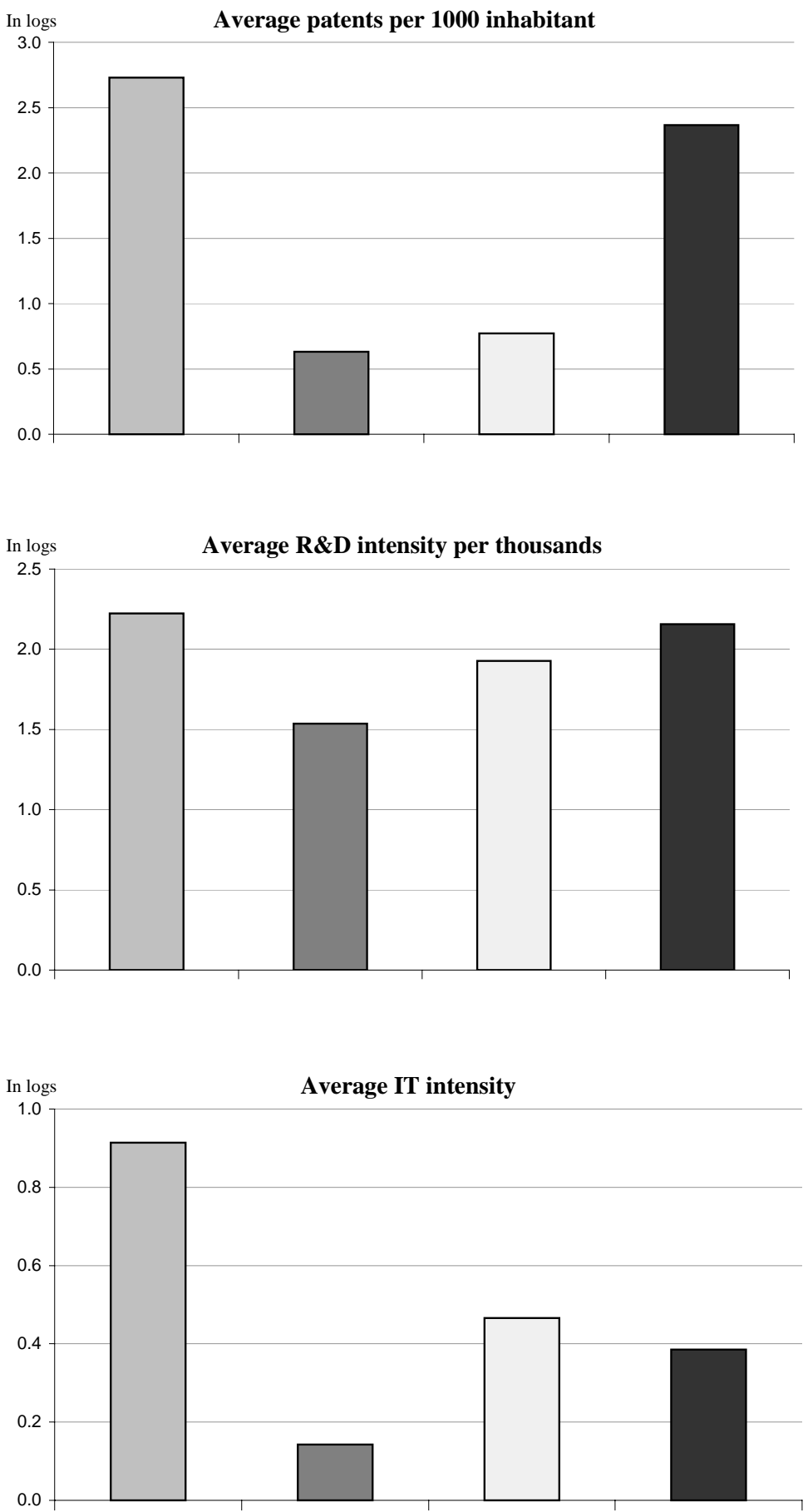

Countries classified by ascending EPL:

Low EPL Low Coordination : USA, GBR, CAN, NZL, AUS, CHE, HUN, BEL, FIN.

High EPL Low Coordination : SWE, FRA, ESP, TUR, PRT.

Low EPL High Coordination : IRL, DNK, CZE, POL.

High EPL High Coordination : AUT, JPN, KOR, NLD, NOR, DEU, GRC, ITA. 
ECO/WKP(2001)38

Table 6. Effects of policies and institutions on R\&D intensity Results of panel regressions

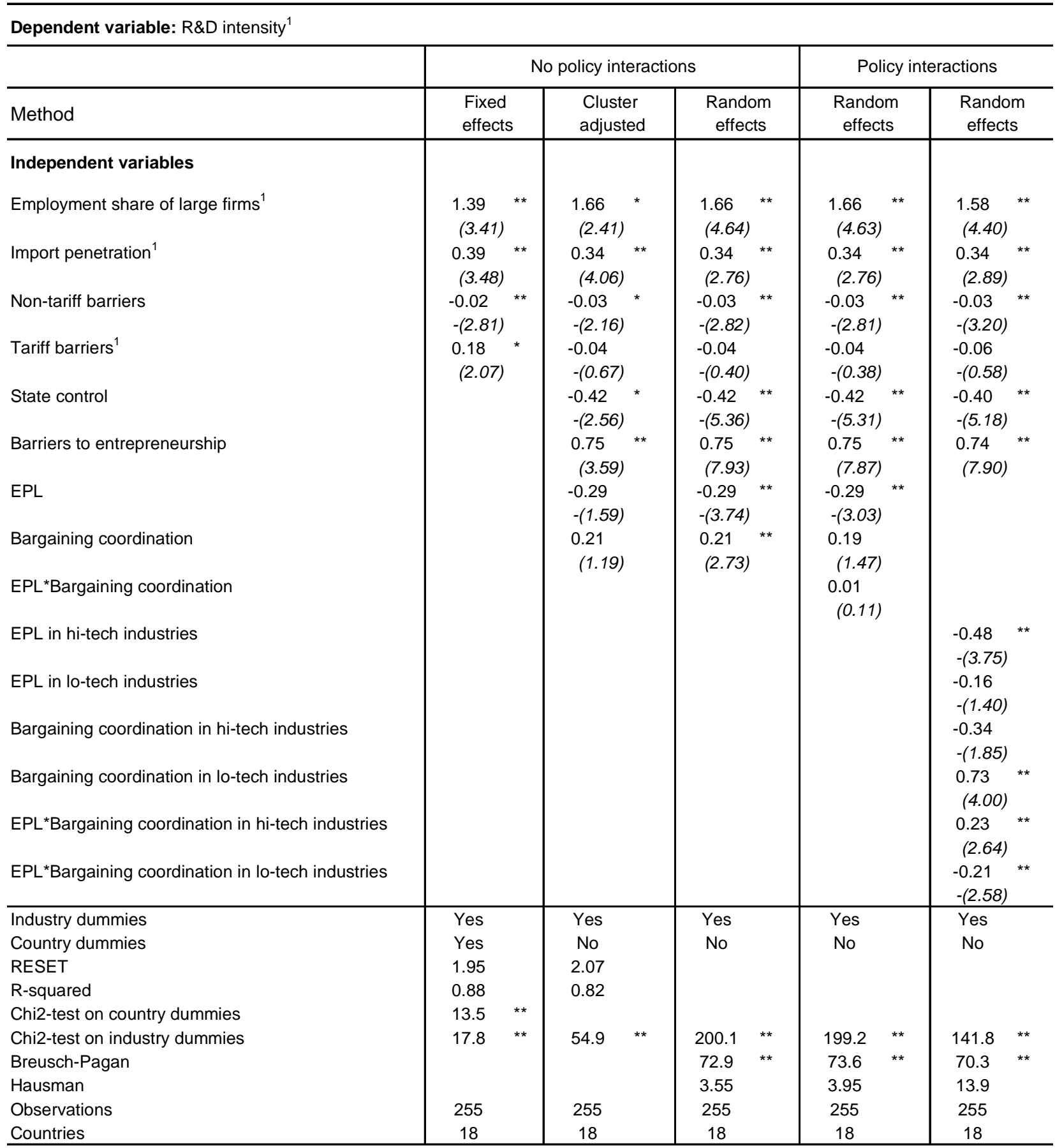

1. In logarithm

Note: All equations includes a constant. ${ }^{*}{ }^{* *}$ denote significance at the $5 \%, 1 \%$ level, respectively. T-statistics in parentheses.

Samples are adjusted for outliers based on the Welsch distance cut-off (Chatterjee and Hadi, 1988).

High-tech industries corresponds to industries 24 and 29-35 of the ISIC Rev. 3 classification. 
Table 7. Net effects of EPL and coordination in industrial relations on R\&D intensity

High-tech industries Low-tech industries

\section{A. Effects of EPL in the context of:}

$\begin{array}{lcc}\text { High bargaining coordination } & 0.25 & -0.29 \text { * } \\ \text { Intermediate bargaining coordination } & -0.61 * * & -(2.1) \\ & -(3.6) & -0.799^{* *} \\ \text { Low bargaining coordination } & -2.28 * & -(4.8) \\ & -(2.0) & -0.53 \\ -(0.7)\end{array}$

B. Effects of bargaining coordination in the context of:

\begin{tabular}{lcc} 
High EPL & $3.04{ }^{*}$ & 0.82 \\
Low EPL & $(2.0)$ & $(1.0)$ \\
& 1.46 & 0.60 \\
\hline
\end{tabular}

Note:

The table reports estimated total effects of EPL(coordination) for given values of coordination (EPL). The estimated model allows for non-linear interaction between EPL and coordination. See Annex 3 for full regressions results.

Panel $B$ reports estimated average effects of raising coordination of one level for 2 groups of countries (high-EPL and low-EPL countries). High-EPL and low-EPL are defined here with respect to the average value of EPL.

${ }^{*},{ }^{* *}$ denote significance at the $5 \%$ and $1 \%$ level, respectively. t-statistics are in parentheses. Samples are adjusted for outliers based on the Welsch distance cut-off (Chatterjee and Hadi, 1988).

35. Based on the estimated net effects of EPL and co-ordination in industrial relations, some conclusions can be drawn as to the role of EPL and industrial relations regimes, and the consequences of different policies for innovation:

- Hiring and firing restrictions generally have negative cross-market effects on innovative activity in low-tech industries and decentralised economies, but no clear cross-market effects can be identified in high-tech industries of co-ordinated economies (Panel A). The result for low-tech industries may reflect the fact that these are generally mature industries with relatively low elasticities of demand. Hence, innovation is more likely to imply downsizing of employment than in high-tech industries, and the costs induced by firing restrictions are potentially higher. The result for decentralised economies can also be explained: lack of coordination in industrial relations requires job turnover and hiring and firing flexibility, so that the skill upgrading associated to innovations can take place efficiently through the open labour market (see above). Moreover, in de-centralised countries, stricter EPL is likely to result in increasing bargaining power of insiders, accentuating rent extraction by workers and discouraging R\&D expenditure. The apparent neutrality of R\&D with respect to EPL in hightech industries of highly co-ordinated countries is consistent with an innovation process based 
on internal labour markets and non-poaching of skills. ${ }^{36}$ On the whole, these results suggest that easing hiring and firing restrictions is likely to raise R\&D intensity in low and intermediate co-ordination countries.

- The cross-market effect of co-ordination on innovative activity is unambiguously positive in high-tech industries of high EPL economies, while its effect in all the other cases is ambiguous (Panel B). The result for high-tech industries in high EPL countries is unsurprising because bargaining institutions that encourage the use of labour reallocations and skill upgrading internal to the firm are advantageous when labour force adjustments are made difficult by legislative provisions. In high-tech industries of low EPL countries, this positive effect is possibly offset by the negative effects of a compressed distribution of wages for hiring skilled labour on the market. ${ }^{37}$ Conversely, low-tech industries innovate more rarely; therefore any strategy based on upgrading of the internal workforce is not likely to induce significant effects on R\&D intensity.

\section{Conclusions on innovation}

36. The policy and institutional environment in the labour market appears to be as important as product market conditions in determining innovation activity in OECD countries. The quantitative effects of labour and product market influences implied by the empirical estimates are often of comparable size (Figure 2), suggesting that the design of labour market policies should take into account their potential repercussions on innovative activity. In high-technology industries, generally accounting for around 70 per cent of all R\&D, the estimated effect of labour market factors is particularly strong in the United States, on the positive side, and France, Portugal and Spain, on the negative side.

37. The cross-market interactions between innovative activity and labour market policies and institutions are complex. The analysis in this section explored some of the possible channels through which these interactions operate, focusing on hiring and firing rules and industrial relations regimes. Based on aggregate data, there seems to be a U-shaped relationship between innovative activity and labour market regimes, defined by different combinations of EPL and co-ordination in industrial relations. R\&D intensity is relatively high either in high EPL/high co-ordination countries or in low EPL/low co-ordination countries, while other combinations of policies and institutions appear to be associated with lower overall innovative activity. This non-linearity emerges also at the industry level, making the comparative statics of changes in policies and institutions difficult to analyse. At the level of aggregation at which data are available, it is impossible to point out which (if any) of the two extreme combinations of EPL and co-ordination in industrial relations is superior from the point of view of innovation outcomes.

36. In co-ordinated countries, the impact of EPL is less negative the larger the scope for internal labour markets in a particular industry which, in turn, depends on the prevailing market structure and the sources of technological change within that industry). The insignificant estimated impact of EPL in high technology industries results indeed from averaging positive and negative effects in different types of industries in that class (see Bassanini and Ernst, 2001).

37. Co-ordination, especially at the employers' level, may also put limits to the ability of firms to poach skills from other firms.

38. For instance, some low-tech industries are supply-dominated industries (Pavitt, 1984, 1995) where innovation is relatively rare and corresponds to further mechanisation of the production process. When competencies are not transferable from one technology vintage to another, hiring skilled labour on the market tends to be less expensive than sponsoring training, thereby reducing the incentive to choose strategies based on internal labour markets. 
Figure 2. The contribution of product and labour market policies and institutions to R\&D intensity in high and low-technology industries ${ }^{1}$

(Percentage deviations from OECD average $)^{2}$

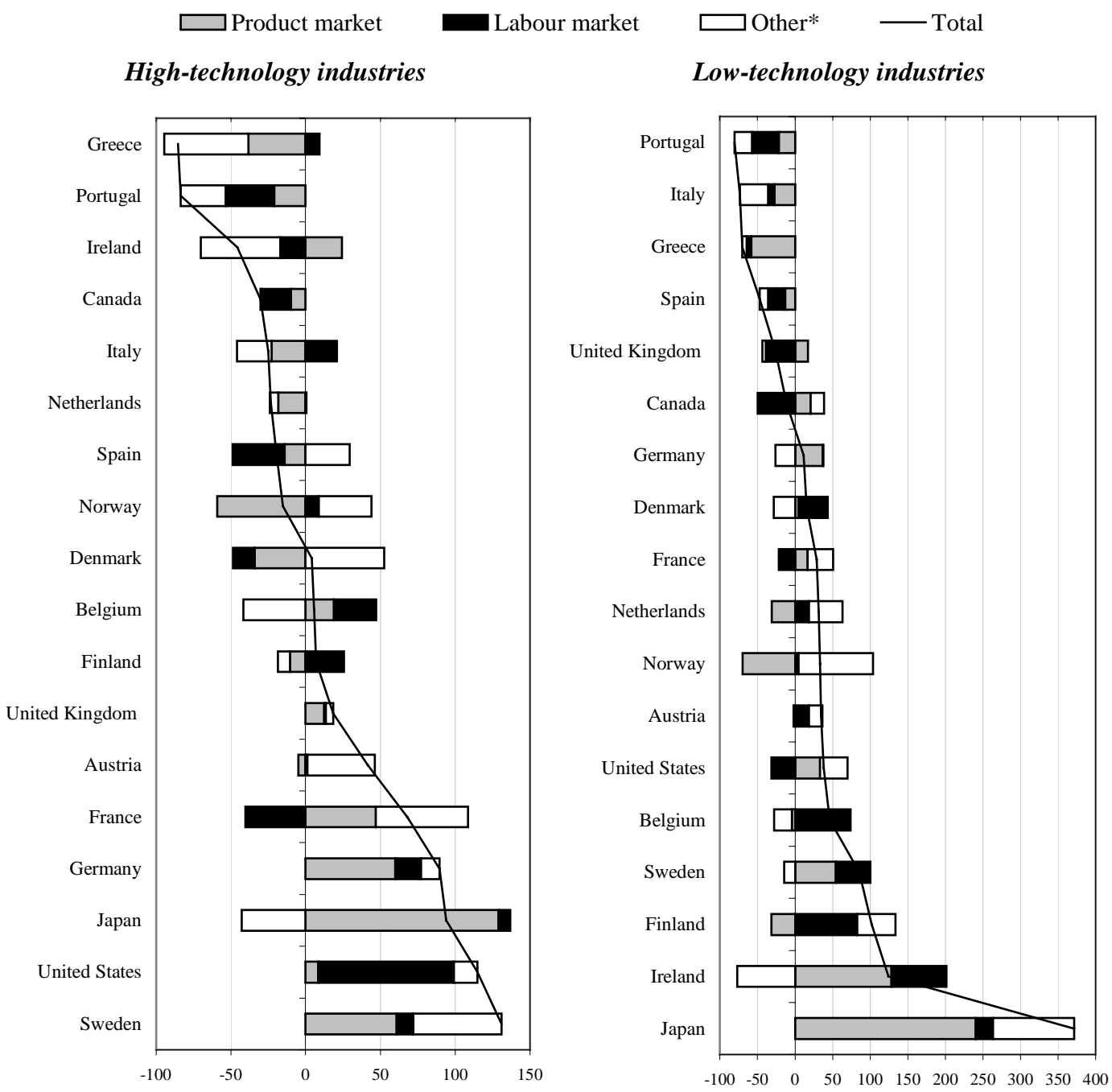

Average contributions
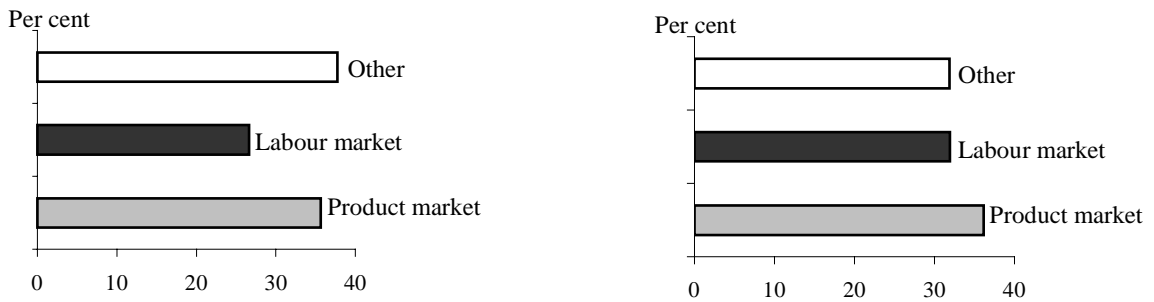

1. Based on the non-linear specification (cf. Table 7 and Annex 4).

2. Adjusted for industry composition.

* Other controls, random effect plus residual. 
38. Despite these ambiguities, at least in one labour market regime (low/intermediate co-ordination and high EPL), differences in EPL appear to play a prominent role in the web of interactions linking labour market arrangements and innovation outcomes, and a relaxation of hiring and firing rules appears to have positive cross-market implications for innovation activity (Table 8). The cross-market implications of changes in EPL policies are less clear in high-co-ordination countries. Table 8. Cross-market effects of EPL and coordination in industrial
relations on R\&D: tentative policy conclusions

\begin{tabular}{l|c|c|}
\hline \multirow{2}{*}{ Initial situation } & \multicolumn{2}{|c|}{$\begin{array}{c}\text { Policy or institutional change likely to have } \\
\text { positive cross-market effects } \\
\text { on R\&D intensity }\end{array}$} \\
\cline { 2 - 3 } & Employment protection & Coordination \\
\hline $\begin{array}{l}\text { Low-intermediate coordination / } \\
\text { Low EPL }\end{array}$ & No change & None \\
$\begin{array}{l}\text { Low-intermediate coordination / } \\
\text { High EPL } \\
\text { High coordination / } \\
\text { Low EPL }\end{array}$ & Decrease & Increase \\
$\begin{array}{l}\text { High coordination/ } \\
\text { High EPL }\end{array}$ & $?$ & None \\
\hline
\end{tabular}

\subsection{Average firm size and innovation activity: intersectoral issues}

39. Country differences in average firm size and R\&D intensity depend on both industry-specific factors and the industry composition of GDP. So far, the analysis has focused mainly on firm size distribution and innovation activity at the level of single industries, exploring the effects of market interactions on cross-industry and cross-country differences in these variables. However, at least in the long run, industry composition could be conceivably as important as industry-specific factors in determining aggregate outcomes. Moreover, in principle, policies and institutions in the labour and product markets, which can have important resource reallocation effects, can also affect industry composition.

40. Figure 3 decomposes for each country the percentage deviations from the OECD average in the share of large firms and R\&D intensity into within-industry and between-industry elements. ${ }^{39}$ The results suggest that, overall and at the level of aggregation examined, differences in industry composition explain only a relatively small part of the differences in both average firm size and R\&D intensity across countries, therefore supporting

39. Details of the decomposition methodology are provided in Annex 1. 
the focus of the analysis on within-industry effects. Nonetheless, industry composition explains a significant part of the relatively low average firm size in Portugal and Poland, while it contributes to explain a relatively larger size in Norway and Belgium. Moreover, composition effects on R\&D intensity are important in several countries, with the United States, Japan, the United Kingdom, Ireland, Finland and Korea having a larger share of inherently R\&D intensive sectors, and Italy, Greece, Norway, Austria and Spain having an industry mix that tends to curb R\&D intensity relative to the OECD average.

Figure 3. Deviation of R\&D intensity and firm size from OECD average : within-sector and industry-composition effects

$\square$ Within sector $\square$ Between sector - Total
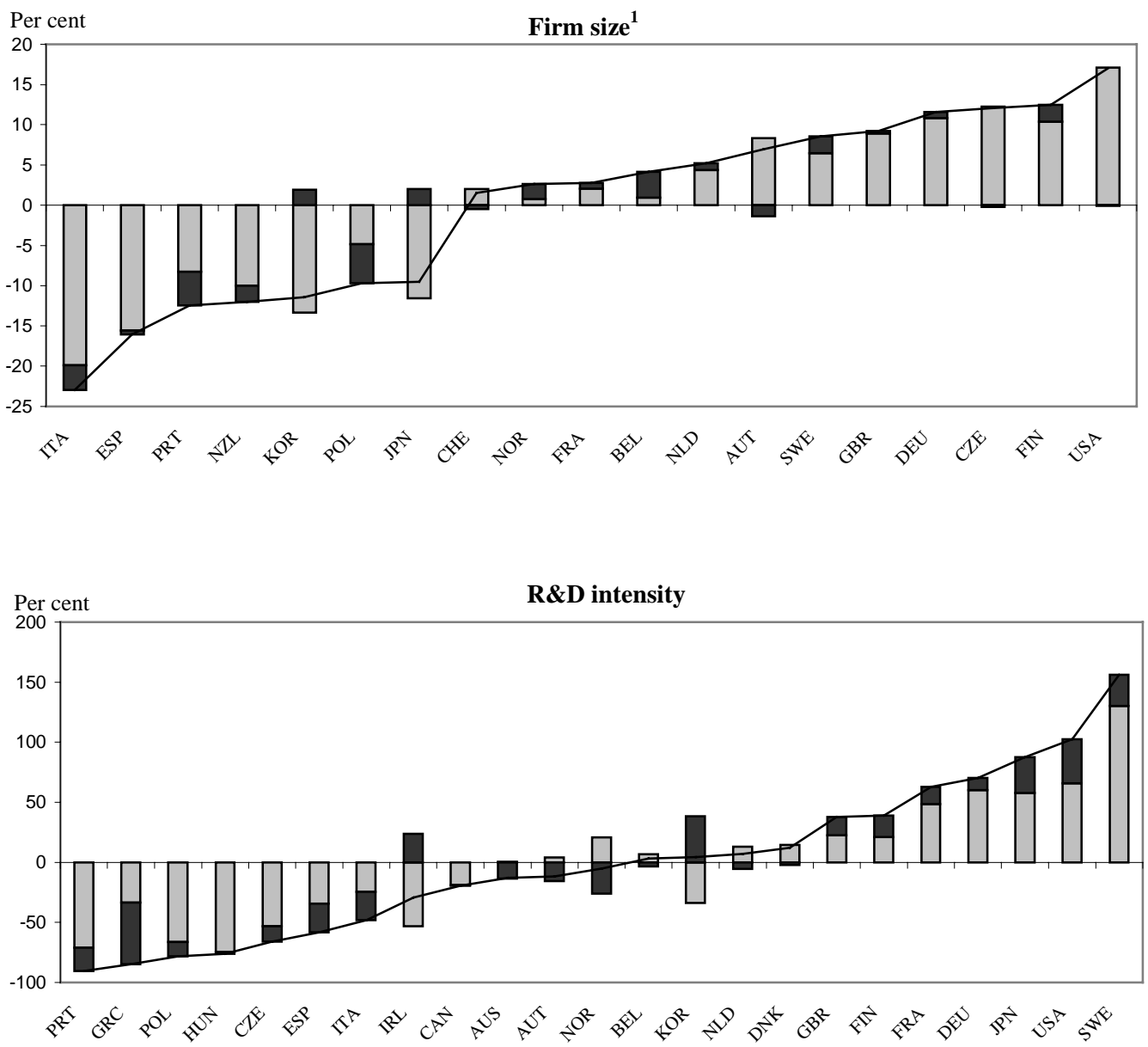

Average contributions

Firm size

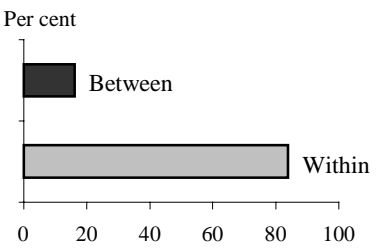

R\&D intensity

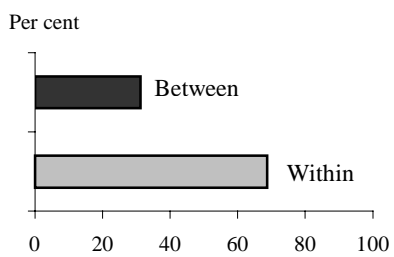

1. Average employment share of firms with more than 50 employees. See Annex 3 for details on decomposition methodology. 
41. Industry composition effects on firm size and $R \& D$ are positively correlated across countries (correlation is 52 per cent and is statistically significant at conventional levels), mirroring the correlation between the share of large firms and innovation activity found at the level of single industries. However, their relationship with policy and institutional variables is different. Due to data limitations, no multivariate analysis of the determinants of industry composition effects is possible. Therefore, Table 9 explores the possible relationship between intersectoral reallocation effects and product and labour market policies and institutions by means of simple bivariate correlations. A number of policies and institutions appear to be associated with industry mixes with lower innovation content. Some of these negative correlations confirm the results of the industry-level analysis, such as with the strictness of EPL (especially concerning temporary contracts and collective dismissals), state control and overall product market regulation. Other results suggest that the tax wedge and the coverage of collective agreements may also be negatively correlated with industry composition effects on R\&D. These results might reflect the fact that these labour (and product) market policies affect the speed of reallocation of resources among industries characterised by different technological opportunity, giving a comparative advantage in high-tech industries to countries in which taxation and firing restrictions are less stringent. No significant correlation was found between intersectoral effects on average firm size and policy and institutional variables.

Table 9. Average firm size and R\&D: product and labour market policies and industry composition effects ${ }^{1}$

Simple bivariate correlations ${ }^{2}$

\begin{tabular}{l|c|c}
\hline \multirow{2}{*}{ Tax wedge } & \multicolumn{2}{|c}{ Effect of industry mix on $:^{3}$} \\
\cline { 2 - 3 } & $\begin{array}{c}\text { Share of large } \\
\text { enterprises }\end{array}$ & $\begin{array}{c}\text { Aggregate R\&D } \\
\text { intensity }\end{array}$ \\
\hline Unemployment benefits & -0.15 & $-0.43^{* *}$ \\
Coverage of collective agreements & 0.17 & -0.13 \\
EPL $\quad 0.33$ & $-0.65^{* * *}$ \\
$\quad$ Regular contracts & -0.06 & $-0.47^{* *}$ \\
$\quad$ Temporary contracts & -0.09 & $-0.33^{*}$ \\
$\quad 0.10$ & $-0.48^{* *}$ \\
Excess regulation on corporations & -0.19 & $-0.60^{* * *}$ \\
Product market regulation & -0.36 & $-0.64 \quad * * *$ \\
$\quad$ State control & -0.07 & $-0.45^{* *}$ \\
$\quad$ Barriers to entrepreneurship & -0.15 & $-0.79^{* * *}$ \\
$\quad$ Barriers to trade & 0.01 & 0.19 \\
\hline
\end{tabular}

1. See Annex 2 for details on the computation of industry composition effects.

2. ${ }^{* *},{ }^{* \star *}$ denote significance at the $5 \%$ and $1 \%$ level, respectively.

3. Log of share of firms with more than 50 employees. 


\section{Effects of market interactions on labour market outcomes}

42. By affecting actual and/or potential competition, product market arrangements may have significant implications for the labour market. There are multiple channels through which product market regulations and regulatory reform can affect labour market performance (see Box 2). This section looks at some of these market interactions, controlling for cross-country and (when relevant and possible) cross-industry differences in labour market arrangements. The focus is on the effects of anti-competitive regulations (e.g. those that create product market rents), which are proxied by a detailed set of economy-wide and industry-specific regulatory indicators, having both a cross-country and time-series dimension (see Table 1). These indicators, and other related measures of product market competition, are used to explain inter-industry wage differentials and the evolution of overall employment rates in the past two decades.

\subsection{Industry wage premia}

43. There is a large amount of evidence pointing to the existence of significant inter-industry wage differentials in OECD countries (see Krueger and Summers, 1988; Gittleman and Wolff, 1993; OECD, 1996, and the references therein; Haisken-DeNew and Schmidt, 1999; Jean and Nicoletti, 2001). These partly reflect differences in worker characteristics (age, gender, education, skills), working conditions (location, health hazards, etc.), and the characteristics of firms (industry affiliation, size, etc.), ${ }^{40}$ but they can also reflect differences in competitive pressures and employee bargaining power across countries and industries, which result in different degrees of rent sharing. Therefore, studying the linkage between anti-competitive product market regulations and wage premia is important to understand the implications of regulatory policies.

44. Empirical evidence on the influence of product market regulation on inter-industry wage differentials is scant, especially at the cross-country level. Conceptually, this linkage can be studied in two different but complementary ways. First, premia should be found to be relatively higher in countries and industries in which regulations restrict competition. Second, premia should decrease as anticompetitive regulations in these countries and industries are removed. A few studies have concentrated on the effects of product market competition on wage premia in single countries or in specific regulated industries. In manufacturing, market power is found to be associated with higher premia (e.g. Nickell et al., 1994, for the United Kingdom), but results for non-manufacturing regulated industries are mixed: while de-regulation is often found to lead to decreases in average earnings (Peoples, 1998), in some cases regulation is found to be associated with lower pay levels and de-regulation is found to lead to either no or positive effects on wage premia (see e.g. Hendricks, 1977, 1994, for the United States). Other studies looked at the effects of trade openness on manufacturing wage premia for single countries (e.g. Gaston and Trefler, 1994, 1995, and Pizer, 2000, for the United States) or across countries (e.g. Oliveira-Martins, 1993). OECD (1996) is the only comprehensive study to date covering both the cross-country, cross-industry and time-series dimensions. Analysis in that study focused on the effects of product market competition rather than regulation. ${ }^{41}$

40. If the labour market is perfectly competitive, wage differentials should reflect only the characteristics of workers. However, wage premia related to the characteristics of firms are consistent with efficiency wage-setting behaviour in which firm profits are increasing with wages over some range. Standard explanations for efficiency wage setting include the wish by the firm to minimise turnover costs, raise worker's effort, increase worker's loyalty and attract better skilled workers (when skills are not observable) (Krueger and Summers, 1988). Stock options may also be considered as a form of rent sharing consistent with efficiency wages. However, the data used in this paper do not allow taking this phenomenon into account.

41. The study covered only average monthly wages in manufacturing industries and controls to account for worker and firm characteristics were limited. 


\section{Box 2. Product market reform and labour market performance: transmission channels}

Competitive pressures among existing firms. Product market deregulation increases competitive pressures among incumbents, raising the elasticity of product demand. At the firm level, for given wages, higher demand elasticity raises output and labour demand. At the aggregate level, if the number of firms remains constant, this results in both higher real wages and higher employment, since aggregate labour demand increases (Nickell, 1999). However, once firm turnover is accounted for, these effects depend on the impact on the number of firms. Under certain conditions, a decrease (increase) in the number of firms could offset (reinforce) the initial effects of product market deregulation on the elasticity of demand, real wages and employment (Blanchard and Giavazzi, 2001).

New entry. Product market deregulation lowers entry costs, encouraging new entry. In general this is likely to lead to a permanent increase in aggregate demand elasticity, real wages and employment (Blanchard and Giavazzi, 2001). The effect on real wages, however, depends crucially on the size of initial rents and the way they are shared between firms and workers, i.e. on the relative bargaining power of workers, among other things (Spector, 2000). Furthermore, in decentralised labour markets, the employment effects of increased product market competition may be hump-shaped because, as competitive pressures increase, employment volatility may rise (firm-level adjustments to shocks rely more on quantities than on mark-ups), possibly leading in extreme cases to higher equilibrium efficiency wages and lower aggregate employment (Amable and Gatti, 2001).

Product and labour market rents. Heightened competition tends to dissipate rents deriving from market power, thereby reducing the scope for rent-seeking behaviour by workers or employers. Where rents were shared with workers in the form of wage premia, these phenomena tend to disappear having negative effects on wages but potentially positive effects on employment. The elimination of non-pecuniary rents (e.g. labour hoarding or managerial slack) may lead to lay-offs in the short-run, but effects on employment are likely to be positive in the long-run when new entry and job reallocation have taken place. Lower wage premia may also reduce unemployment persistence by increasing the sensitivity of wages to labour market slack (Nickell et al., 1994) and lower frictional unemployment by reducing "wait unemployment" (Kletzer, 1992) and "queuing" phenomena, due to lower effective replacement rates (measured against market wages).

Entrepreneurship. As barriers to entry are lowered, the supply of a particular type of capital, entrepreneurial ability, may increase: the level of employment may be positively affected by the increased rate of enterprise creation and survival (OECD, 1998; Krueger and Pischke, 1997).

45. Drawing on Jean and Nicoletti (2001), this section presents a cross-industry and cross-country empirical analysis of the implications of product market regulations for wage premia. The analysis is crosssection and, therefore, is aimed at checking whether there is evidence that labour market rents are relatively high where regulation is most restrictive of competition. To this end, both the cross-country and cross-industry variations in regulations are exploited. It should be stressed at the outset that the analysis cannot directly account for non-pecuniary rents, such as labour hoarding or low work effort, for which adequate controls are lacking. To the extent that generic country and industry effects do not capture these rents, their omission may blur the estimated relationship between regulation and wage premia.

46. The empirical strategy follows closely the two-step approach taken in OECD (1996). ${ }^{42}$ First, wage premia are estimated, country by country, regressing wages on industry dummies and a set of observable characteristics of workers in each industry. These estimates are based on detailed data on hourly wages earned by different categories of workers, distinguished by type of contract (full-time or part-time), age, sex and

42. This approach was adopted, among others, by Katz and Summers (1989), who applied it to micro data. 
education levels. ${ }^{43}$ Second, the estimated wage premia are regressed on a set of industry and/or country-specific explanatory variables pooling together countries and industries (see Annex 2 for details). Second-step estimates explicitly account for the influence of product and labour market policies and institutions on wage premia. ${ }^{44}$ The analysis focuses on a single year (in or around 1996) and the data cover 11 OECD countries (10 EU countries and the United States) and 41 two-digit industries in both manufacturing and non-manufacturing sectors, where the variability of product market conditions is largest.

47. The estimated wage premia (see Annex 2) are jointly significant at conventional levels and their individual standard errors are generally low and broadly uniform across industries and countries (with the exception of France where wage premia are less precisely estimated). ${ }^{45}$ In all countries the estimated profiles are consistent with standard Mincerian equations, with wages increasing with age and education levels and a significant gender effect. Consistent with previous findings (Gittleman and Wolff, 1993; OECD, 1996), the cross-industry structure of wage premia is remarkably similar across countries, with correlations with the U.S. structure ranging from 35 per cent in Denmark to 90 per cent in Canada. The highest premia are generally found in the manufacturing of tobacco and petroleum products, in utilities (gas and electricity), in the supply of financial and computer-related services and in air transport. The lowest premia are found in the manufacturing of wearing apparel and leather products, in retail trade and, especially, in hotels and restaurants. On the other hand, the inter-industry dispersion of wage premia is substantial in all countries, with standard deviations ranging from 8 per cent in Sweden to 16 per cent in the United Kingdom and Canada. ${ }^{46}$ Wage dispersion has the same magnitude in manufacturing and non-manufacturing industries separately. The estimated wage premia may reflect both efficiency wages and pure rent sharing deriving from workers' bargaining power in the presence of product market rents. ${ }^{47}$ However, only the pure rent element can be expected to fall with product market competition.

48. Second-step regressions relate the estimated wage premia to two sets of variables: controls for firm heterogeneity, and indicators of product market competition and workers' bargaining power, reflecting the ability of workers to capture part of the rents earned by firms operating in imperfectly competitive markets. Aside from industry dummies in fixed-effects regressions, industry-specific controls for firm heterogeneity include average firm size, $R \& D$ intensity, export intensities and occupational composition of the workforce (which may not have been fully accounted for in first-step regressions). To the extent that firm size and R\&D expenditure are themselves affected by regulation (see above), the regressions estimate the effects of regulation on wage premia over and above the indirect effects through these control variables. ${ }^{48}$ Controls for competitive

43. A symmetric analysis was performed also for monthly wages, part-time workers and different occupational categories. The wage premia estimates based on monthly wages of full-time workers distinguished by occupational category are highly correlated with previous estimates by OECD (1996).

44. This makes it possible to avoid the endogeneity bias implicit in proxying product market competition by markups or concentration indices, which are co-determined with wages. A similar approach, though at a higher level of aggregation, was taken in Nicoletti et al. (2001). For details on model specification, see Jean and Nicoletti (2001).

45. In this document, the focus is on interindustry differences in wage premia. Comparing relative levels of wage premia in one industry across countries requires an assumption as to which industry can be taken to be the common "competitive" benchmark in which premia are lowest. This line of reasoning is not pursued here.

46. Standard errors were adjusted for sampling error, as in Krueger and Summers (1988). The estimated dispersion of wages in the United States (11 per cent) is broadly consistent with the dispersion found by these authors based on 1984 micro data (14 per cent)

47. In an efficiency-wage perspective, wage premia correspond to the compensation paid by firms for avoiding the costs of monitoring, collecting information, etc. Even conceptually, the distinction between efficiency-wage and rent-sharing elements is difficult. To the extent that rent sharing is a device to avoid the costs of labour unrest, it can also be seen as part of efficiency wages (Krueger and Summers, 1988).

48. However, the potential bias induced by these indirect effects appears to be negligible in actual estimations (see below) and results do not change when firm size is instrumented. 
pressures include industry-specific indicators of product market regulation, entry rates and import penetration rates. Industry-specific union densities control for the bargaining power of workers. Given the wide differences in the characteristics of firms and market environments in manufacturing and non-manufacturing industries (for instance in terms of trade openness, industry regulation and innovative activity), the analysis of the determinants of wage premia was performed separately for these two sets of industries. Due to lack of the relevant data, two simplifying hypotheses were made: in manufacturing, product market regulation was proxied by tariff and nontariff barriers, assuming that no other industry-specific regulations restrict domestic competition; in nonmanufacturing, no trade variables were included, assuming that in these industries competitive pressures coming from imported products are insignificant. ${ }^{49}$

49. Table 10 summarises the results of second-step panel regressions for manufacturing and nonmanufacturing industries (see Annex 2 for details). ${ }^{50}$ The estimated manufacturing equations have a basic structure that is consistent with the approach taken in OECD (1996) but, depending on model specifications, industry dummies or cross-country averages of industry-specific entry rates account for differences in market structure across industries. ${ }^{51}$ Moreover, the differential effect of unionisation on wage premia in industries with different occupational characteristics (Card, 1996) was checked by crossing the skill structure of employees by industry with union density in manufacturing. ${ }^{52}$ The results of the specification tests (RESET and Hausman) suggest that the fixed-effects model fits the data best.

50. Several conclusions can be drawn from the regression results for manufacturing industries:

- Product market competition curbs wage premia. Import penetration has a significant negative effect on wage differentials. Moreover, wage premia tend to be lower in industries characterised by higher entry rates.

- Trade barriers increase wage premia. In the preferred specification, both tariff and non-tariff barriers tend to push up wage differentials, perhaps reflecting the appropriation by workers of the rents implied by market power or cost advantages for domestic producers. ${ }^{53}$ This effect comes over and above the potential impact barriers may have on import penetration.

49. In non-manufacturing industries, significant competitive pressures can originate from foreign direct investment and the activity of affiliates of foreign firms. Unfortunately, limited industry and country coverage precluded the use of these data in empirical analysis. Potential omitted variables problems implied by the simplifying assumptions concerning trade in non-manufacturing industries are likely to be reduced by the use of variables related to market concentration in manufacturing (firm size, entry rates) and the inclusion of information on discrimination against foreign companies in the regulatory indicators for non-manufacturing industries.

50. Given that premia are defined in relative terms within each country, industries were chosen as the units defining the panel dimension of the empirical model. To model explicitly effects that are common to all countries but vary across industries, both fixed-effects and random-effects specifications (dropping the industry dummies) were estimated. Fixed-effects regressions were performed using unweighted industry wage premia, but observations were weighted by the inverse of the standard error of their estimation in the first stage to control for sampling error and for possible heteroskedasticity.

51. A notable difference with OECD (1996) is that equations always include both country dummies and industryspecific effects, while the latter were absent in earlier OECD estimates. The analysis in OECD (1996) distinguished between segmented and fragmented industries assigning each industry in the sample to one of the two categories. Here, industry-specific effects are introduced either as industry dummies or as cross-country averages of the industry entry rates estimated in OECD (2001b) for a subset of OECD countries. Standard F-tests reject the specification with no industry-specific effects and controlling for them improves the fit of the model in the dimension in which wage premia vary the most.

52. No union density data are available for manufacturing branches.

53. This result is consistent with findings by Nicoletti et al. (2001), obtained using more aggregated data. 
Table 10. The effects of policies and institutions on wage premia

Results of panel regressions

Dependent variable : Estimated hourly wage premia for full-time workers

\begin{tabular}{|c|c|c|c|c|c|c|c|}
\hline \multirow{3}{*}{$\begin{array}{l}\text { Method } \\
\text { Tariff barriers }\end{array}$} & \multicolumn{3}{|c|}{ Manufacturing sector } & \multicolumn{4}{|c|}{ Non-manufacturing sector } \\
\hline & $\begin{array}{l}\text { Fixed } \\
\text { effects }\end{array}$ & $\begin{array}{l}\text { Cluster } \\
\text { adjusted }\end{array}$ & $\begin{array}{c}\text { Random } \\
\text { effects }\end{array}$ & \multicolumn{2}{|c|}{ Fixed effects } & $\begin{array}{l}\text { Cluster } \\
\text { adjusted }\end{array}$ & $\begin{array}{c}\text { Random } \\
\text { effects }\end{array}$ \\
\hline & $\begin{array}{l}0.33 \text { * } \\
(2.51)\end{array}$ & $\begin{array}{l}0.08 \\
(0.69)\end{array}$ & $\begin{array}{l}0.19 \\
(3.19)\end{array}$ & & & & \\
\hline Non-tariff barriers & $\begin{array}{l}0.12 \\
(2.43)\end{array}$ & $\begin{array}{l}-0.01 \\
(-0.64)\end{array}$ & $\begin{array}{l}-0.01 \\
(-0.52)\end{array}$ & & & & \\
\hline Product market regulation & & & & $\begin{array}{l}0.23 \\
(2.35)\end{array}$ & $\begin{array}{l}0.29 * \\
(2.37)\end{array}$ & $\begin{array}{l}0.20 \\
(1.63)\end{array}$ & $\begin{array}{l}0.20 * \\
(2.14)\end{array}$ \\
\hline Non-linear effect of regulation ${ }^{1}$ & & & & $\begin{array}{l}-0.57 \\
(-3.52)\end{array}$ & $\begin{array}{l}-0.63 \\
(-3.64)\end{array}$ & $\begin{array}{l}-0.55 \\
(-3.28)\end{array}$ & $\begin{array}{l}-0.55 \quad * * \\
(-3.01)\end{array}$ \\
\hline Import penetration rate ${ }^{2}$ & $\begin{array}{l}-0.03 \\
(2.48)\end{array}$ & $\begin{array}{l}-0.03 \\
(-2.96)\end{array}$ & $\begin{array}{l}-0.03 \\
(-3.41)\end{array}$ & & & & \\
\hline Export intensity $^{2}$ & $\begin{array}{l}0.02 \\
(1.69)\end{array}$ & $\begin{array}{l}0.00 \\
(-0.48)\end{array}$ & $\begin{array}{l}0.003 \\
(0.32)\end{array}$ & & & & \\
\hline Union density $^{2}$ & & & & & $\begin{array}{l}0.03 \\
(1.52)\end{array}$ & $\begin{array}{l}0.03 * \\
(2.04)\end{array}$ & $\begin{array}{l}0.03 \\
(1.95)\end{array}$ \\
\hline $\begin{array}{l}\text { Union density * average share of } \\
\text { unskilled workers }{ }^{3}\end{array}$ & $\begin{array}{l}0.10 \text { * } \\
(5.23)\end{array}$ & $\begin{array}{l}0.11 \text { ** } \\
(4.47)\end{array}$ & $\begin{array}{l}0.11 \text { * } \\
(5.37)\end{array}$ & & & & \\
\hline $\operatorname{Size}^{2}$ & $\begin{array}{l}0.05 \\
(3.67)\end{array}$ & $\begin{array}{l}0.07 \\
(6.86)\end{array}$ & $\begin{array}{l}0.06 \\
(5.80)\end{array}$ & & & & \\
\hline$R \& D^{2}$ & $\begin{array}{l}0.002 \\
(0.33)\end{array}$ & & & & & & \\
\hline
\end{tabular}

Country-independent variables :

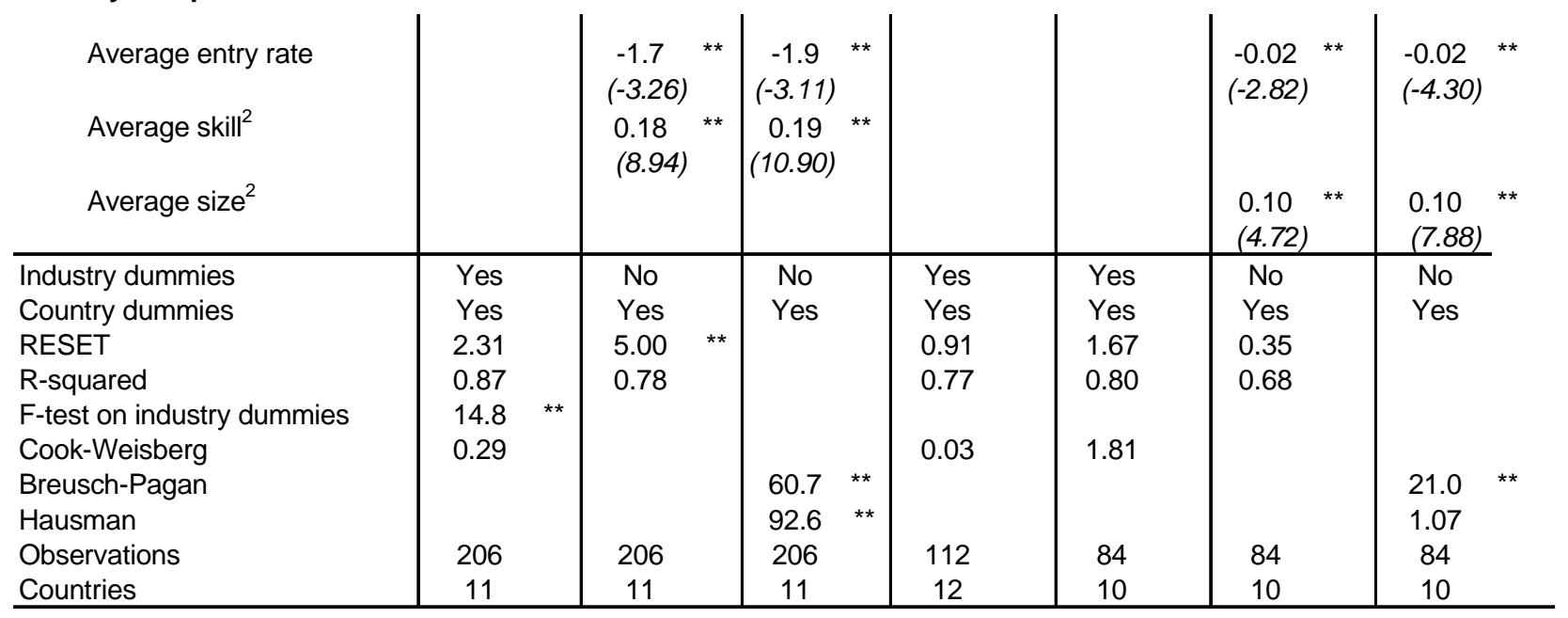

Note: All equations includes a constant. ${ }^{*},{ }^{* \star}$ denote significance at the $5 \%$ and $1 \%$ level, respectively.

T-statistics in parentheses. Samples are adjusted for outliers.

All variables in logs except tariff barriers, non-tariff barriers and entry rates.

1. Defined as the product of the industry-specific product market regulation indicators and their deviations from their industry me

2. In logarithm.

3. Product of the average union density in manufacturing for the country, by the (country-independent) average share of unskille workers (see Annex 2 for details).

Source : Jean and Nicoletti (2001). 
- Wage premia tend to be higher as the share of unionised unskilled workers increases. The positive and significant coefficient estimated for the interaction variable suggests that the effect of unionisation on wages $i s$ relatively stronger for unskilled workers or, alternatively, that the bargaining power of unions decreases with the share of skilled labour. ${ }^{54}$

- Structural influences on industry wage premia include average firm size and occupational structure. Wage premia increase with firm size and the share of skilled workers, possibly reflecting efficiency-wage phenomena. ${ }^{55}$ The influence of export intensity is not significant.

51. Non-manufacturing equations were specified in a broadly similar way, with wage premia depending on firm size, entry rates, union densities and product market regulation. Due to the lack of appropriate data, R\&D could not be used as an explanatory variable. However, more accurate data than for manufacturing were available for both union density, which cover several utilities and service industries, and regulation. Figure 4 plots the first-step estimates of non-manufacturing wage premia against the industry-specific summary indicators of product market regulation, showing the picture for both industries and countries. There is some evidence of a positive correlation between the two phenomena (the correlation coefficient is 0.3 and is significant at conventional levels), though it is blurred by the relatively high dispersion of wage premia.

52. The bivariate evidence is only partly confirmed by the results of panel regressions, which provide a picture of a strong but more complex relationship between wage premia and regulation in non-manufacturing industries (see below). Factors related to industry and market structure have broadly the same effects as in manufacturing, with higher wage premia in non-manufacturing industries characterised by a larger average firm size and product market competition (proxied by entry rates) having a significant moderating impact on wage premia. Moreover, workers' bargaining power (as proxied by industry-specific union densities) is significantly associated with higher wage premia in the cluster-adjusted specification. However, contrary to manufacturing, the effect of product market regulation on wage premia is hump-shaped, with decreasing premia observed in tightly regulated industries.

53. For illustrative purposes, Figure 4 (Panel B) also plots the relationship between the first-step estimates of the wage premia, net of country and industry-specific effects, and product market regulation. The decreasing part of the hump-shape mostly describes the relationship between regulation and wages in countries/industries that are dominated by public-owned and tightly regulated incumbents. In principle, this could reflect the success of regulation in curbing product market rents and rent-sharing in some industries (e.g. utilities). However, a more likely explanation, consistent with efficiency wages, is that pervasive regulation increases the possibility of regulatory failure, leading to both low labour productivity and wages. Lighter or more arm's length regulatory approaches may lead to a more efficient use of inputs (see Hendricks, 1994). A supplementary explanation of the hump-shaped relationship is that by sheltering firms from competition, regulation preserves product market rents that are shared with workers in both pecuniary and non-pecuniary ways. ${ }^{56}$ Non-pecuniary rents become more viable as regulation becomes tighter, interfering with all dimensions of business activity (ownership, objectives, input and output choices) such as in many public-owned utilities. ${ }^{57}$ These conjectures have been further explored by Jean and Nicoletti

54. Acemoglu et al. (2001) argue that this reduction in bargaining power is related to the wider outside options for skilled workers, which undermines the coalition among skilled and unskilled labour in support of unions.

55. The positive relationship between wages and firm size, even after controlling for observable worker characteristics and other job attributes, is a common empirical finding (for a review, see Oi and Idson, 1999).

56. Non-pecuniary rents can take the form of weak work incentives (e.g. lack of monitoring), inefficient utilisation of inputs (e.g. labour hoarding) and other business practices that induce firms to operate within the efficiency frontier (so-called X-inefficiency) while increasing the utility of workers.

57. There are many reasons for this phenomenon. For instance, public-owned firms are typically more exposed to political interference and profit maximisation is often overridden by other objectives, which may be consistent 
(2001), who provide evidence supporting interpretations of the hump-shape based on regulatory failure and/or non-pecuniary rents in public monopolies.

Figure 4. Wage premia and regulation in non-manufacturing industries

\section{A. First-step estimates}
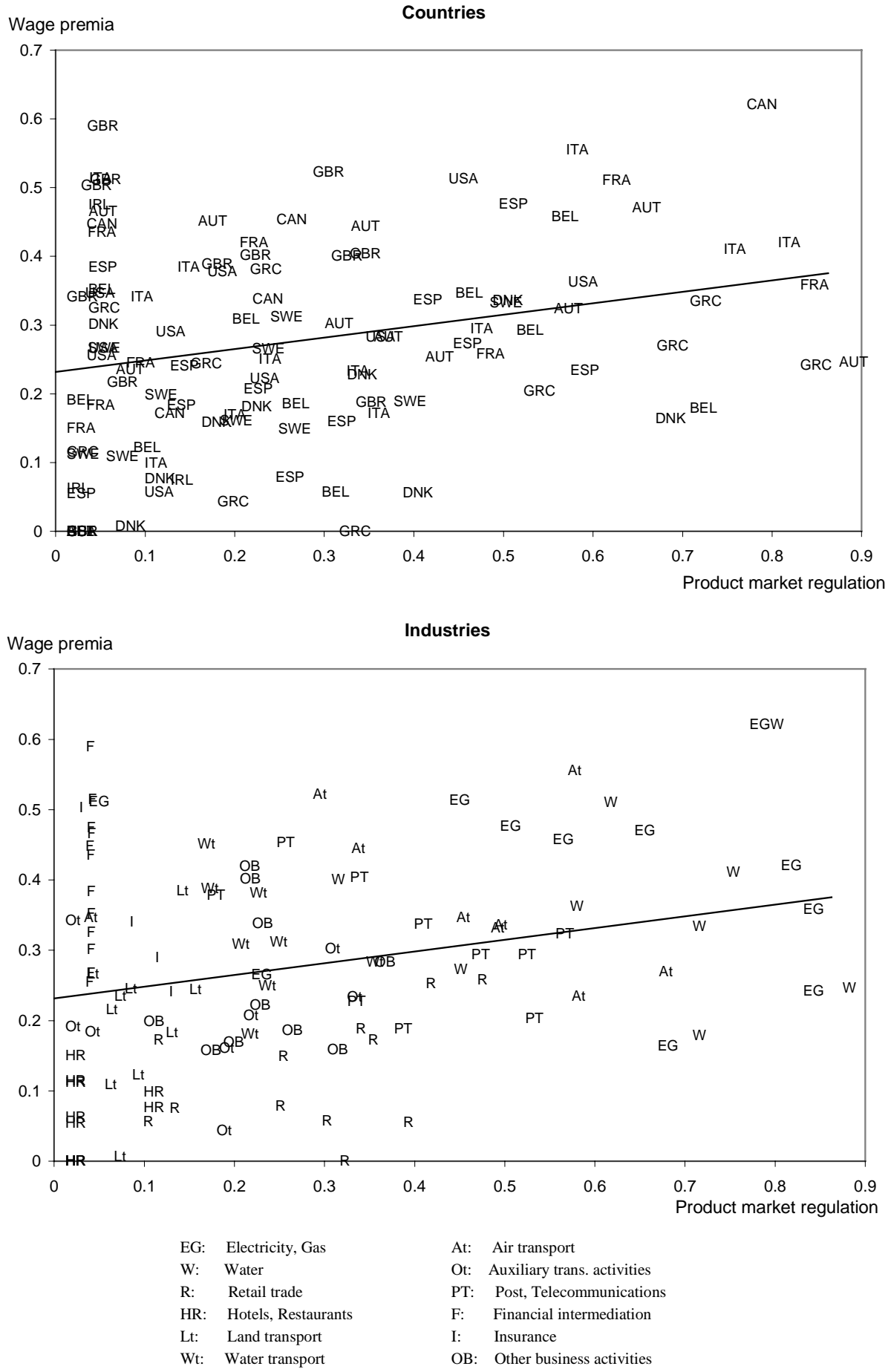

with some degree of X-inefficiency (Haskel and Sanchis, 1995); "public service" considerations and strong union participation make high pay levels and pay inequalities less politically acceptable. 
ECO/WKP(2001)38

Figure 4 (continued). Wage premia and regulation in non-manufacturing industries

\section{B. Net of influences other than regulation}
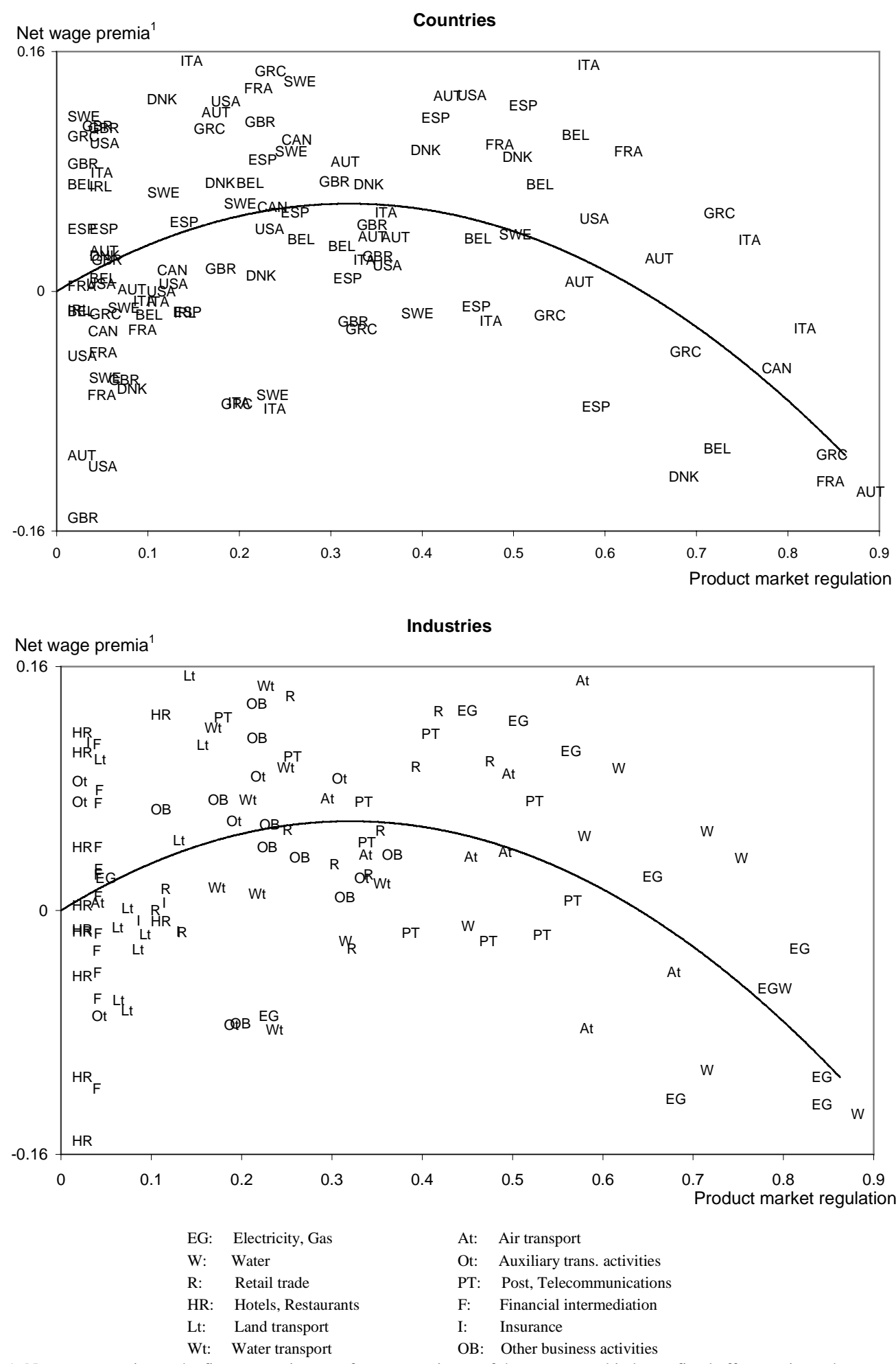

1. Net wage premia are the first step estimates of wage premia net of the country and industry fixed effects estimated in Table 10 (column 4)

Source: Jean and Nicoletti (2001). 


\section{$\mathrm{ECO} / \mathrm{WKP}(2001) 38$}

\section{Conclusions on wage premia}

54. OECD labour markets are characterised by the existence of sizeable interindustry wage differentials, which cannot be explained solely by differences in worker and firm characteristics. Product market conditions appear to be important determinants of the implied wage premia, which therefore are likely to reflect in part the sharing of product market rents between firms and workers. In most industries, wage premia are higher when regulatory barriers to international and domestic trade curb product market competition. For instance, the empirical estimates for manufacturing imply that, for the average OECD country, a reduction of one point in average trade tariffs or a 10 per cent increase in import penetration would each lower wage premia by around 0.3 per cent. In non-manufacturing industries, the picture is more complex, since wage premia first rise and then fall as regulatory barriers to competition become more stringent. Although, in principle, this may result from the successful elimination of product and labour market rents by regulation, it is more likely to reflect nonpecuniary rents and/or low efficiency outcomes in heavily regulated utility industries. In any case, in relatively competitive non-manufacturing industries (with intermediate initial levels of regulation), the estimates suggest that full product market liberalisation (as measured, for instance, by a fall to zero of the average value of the regulatory indicator) can lower wage premia by up to 8 per cent.

\subsection{Specialisation in high-wage and high-R\&D industries}

55. Using the estimates of inter-industry wage differentials, OECD countries can be compared according to their specialisation in industries typically characterised by high wage premia. For each country, the indicator of specialisation weights the share of employment in each manufacturing industry by the average across countries of the corresponding wage premia estimated in the countries included in the sample. Using a similar indicator, countries can also be compared according to their specialisation in high-R\&D industries. ${ }^{58}$ Figure 5 shows that the two indicators are highly correlated across countries, with countries that specialise in high-R\&D industries also specialising in industries with high wage premia. This relationship suggests that specialisation in the two dimensions may be driven by the same forces, consistent with theories of co-determination of efficiency wages and choice of technology (Acemoglu and Shimer, 2000). ${ }^{59}$

56. Table 11 explores the possible relationship between specialisation in high-wage industries and policies and institutions in a simple bivariate framework. The index of specialisation is related across countries to product market regulations and labour market policies and institutions. The resulting correlations suggest that countries where product market regulations and employment protection legislation (especially for temporary contracts and collective dismissals) are relatively strict also tend to specialise in industries characterised by low wage premia. Similar negative correlations were found between product and labour market regulations and industry composition effects on aggregate R\&D intensity (Table 9). Given the close relationship between specialisation in high-R\&D and high-wage industries, a possible interpretation of these bivariate correlations is that regulatory settings that discourage specialisation in high-wage industries also may impair a country's innovation potential. This interpretation should however be considered highly tentative since other factors could drive differences in specialisation patterns across countries.

58. Due to data limitations, specialisation indicators do not include non-manufacturing industries. The indicators are increasing in the degree of high-wage and high-R\&D industry specialisation. See Annex 1 for details on the methodology used to construct them.

59. R\&D investment calls for skilled labour and skilled labour calls for high wage premia; conversely, high wage premia may induce the choice of innovative labour-saving technologies. 
Figure 5. Specialisation in high wage and high R\&D industries ${ }^{1}$

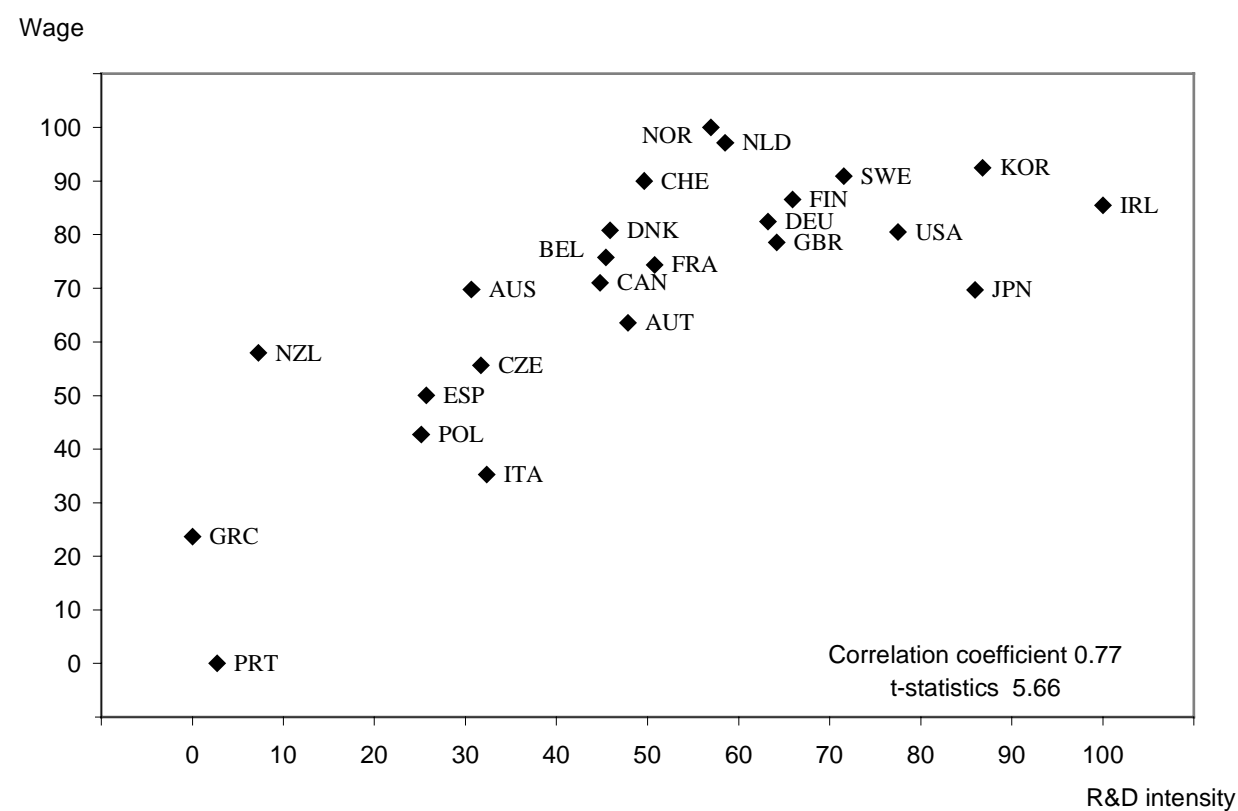

1. Indices of employment specialisation according to average inter-industry wage premia and average $R \& D$ intensities (as estimated by industry dummies in fixed-effect regressions).

See Annex 3 for details on the construction of the indicators of specialisation.

Table 11. Product and labour market policies and specialisation in high wage premia industries ${ }^{1}$ Simple bivariate correlations ${ }^{2}$

\begin{tabular}{|c|c|c|c|c|c|}
\hline \multicolumn{3}{|c|}{ Product market regulations } & \multicolumn{3}{|l|}{ Labour market policies } \\
\hline Excess regulation on corporations & -0.51 & ** & Tax wedge & -0.08 & \\
\hline Product market regulation & -0.36 & * & Unemployment benefits & 0.24 & \\
\hline State control & -0.5 & ** & Coverage of collective agreements & 0.02 & \\
\hline Barriers to entrepreneurship & -0.03 & & $E P L$ & -0.43 & ** \\
\hline Barriers to trade & -0.19 & & Regular contracts & -0.32 & \\
\hline & & & Temporary contracts & -0.44 & ** \\
\hline & & & Collective dismissals & -0.37 & * \\
\hline
\end{tabular}

1. See Annex 2 for details on the index of industry specialisation in industries with high wage premia.

2. ${ }^{*},{ }^{* *}$ denote significance at the $10 \%$ and $5 \%$ level, respectively. 


\section{$\mathrm{ECO} / \mathrm{WKP}(2001) 38$}

\subsection{Employment rate}

57. Although the primary (short and long-run) implications of stronger product market competition are to increase output and productivity, competition may also affect aggregate employment in a variety of ways (see Box 2). Economic analysis suggests that, in most cases, an increase in employment is the expected outcome (Blanchard and Giavazzi, 2001). However, the effects on employment will depend on the particular policies that brought about an increase in product market competition as well as on the underlying labour market policies and institutions. ${ }^{60}$ Moreover, the effects on employment are likely to be different in the short and long run, when firm turnover and intersectoral reallocations of labour have fully unfolded. ${ }^{61}$ Therefore, the effects of competition on employment are ultimately an empirical issue.

58. This section analyses the evidence on the long-run effects of product market competition on employment rates in 20 OECD countries over the 1982-1998 period. Differences in product market competition across countries and over time are proxied by differences or changes in the friendliness of product market regulations to market mechanisms. Focusing on product market regulation instead of other proxies for competition (such as concentration rates, mark-ups or business surveys) has the advantage of relating employment performance directly to the policy factors that affect market competition, once other structural factors (such as country-specific technological characteristics) have been accounted for. Evidence on the implications of cross-country differences in product market regulations for aggregate employment was produced by Boeri et al. (2000) and Nicoletti et al. (2001). Drawing on Nicoletti and Scarpetta (2001), this section updates these analyses and takes a further step by looking at the effects of product market regulatory reform. To this end, the (static) summary indicators of economy-wide regulation presented in OECD (1999a) were supplemented with a time-varying regulatory indicator, which was constructed for each country in the sample based on detailed information on regulatory developments in several service industries (Box 3).

59. Table 12 shows the evolution of the time-varying regulatory indicators for the countries included in the sample. Over the past two decades, regulatory reform (as measured by both the absolute variation and the percentage decline in the regulatory indicator) was deepest in the United Kingdom, New Zealand, the United States and Australia, while policies changed relatively little in Southern European countries, Ireland and Switzerland. Three main country groupings can be identified looking at the evolution of regulatory indicators: the United States, which began regulatory reform at the turn of the 1980s; the United Kingdom, New Zealand and Canada, which began reforming during the 1980s; and most other countries, which changed regulatory policies over the 1990s. In 1998, the cross-country correlation between the timevarying regulatory indicator and the summary economy-wide indicator of regulation is close to 70 per cent, suggesting that the former is a reasonable proxy for the latter.

60. For instance, a lowering of entry costs (e.g. implied by regulatory barriers) is likely to have a larger positive long-run effect on employment than a mere increase in the intensity of competitive pressures (e.g. induced by changes in competition policies), because it implies an increase in the number of firms at equilibrium (Blanchard and Giavazzi, 2000). In flexible labour markets, employment may become more volatile in the short-run as product market competition is increased, but labour readjustments to a new equilibrium may be quicker.

61. For instance, productivity improvements induced by competitive pressures are often obtained through labour shedding in the short-run, but output expansion and new entry are likely to offset these employment losses only over time. Similarly, downward pressure on product and labour market rents stimulates employment as wage premia decline in sheltered industries (see above), but may also translate into lay-offs and/or increased work effort where rent sharing was non-pecuniary in form. 


\section{Box 3. Describing regulatory reform in OECD countries}

To describe past developments in product market regulation, the data used in this paper cover regulations and market conditions in seven energy and service industries over the 1970-1998 period: gas, electricity, post, telecommunications (mobile and fixed services), passenger air transport, railways (passenger and freight services) and road freight. The coverage of regulatory areas varies across industries (see Table below). While regulatory barriers to entry are reported for all industries, the coverage of other regulatory dimensions is tailored to each industry, reflecting both industry characteristics and data availability. Market structure is documented for gas, telecommunications and railways to provide information about the actual enforcement of regulatory provisions.

As in the construction of economy-wide indicators (Nicoletti et al., 1999), countries were classified in each period along a 0-6 scale from least to most restrictive on each of the regulatory and market dimensions covered in the analysis. Industry-specific time-series indicators of regulatory and market environment were created by taking a simple average of the regulatory and market features covered in each industry and the aggregate timeseries indicator used in regression analysis was obtained by averaging over all industries in each country. The resulting indicators were interpreted as a proxy for the overall regulatory policies followed by OECD countries over the sample period. Details on sources and methodology are provided in Annex 1.

\section{Sectoral composition of aggregate time-series indicators} of regulatory reform

\begin{tabular}{lccccc}
\hline \multirow{2}{*}{$\begin{array}{l}\text { Airlines } \\
\text { Railways }\end{array}$} & $\begin{array}{c}\text { Entry } \\
\text { Road }\end{array}$ & $\begin{array}{c}\text { Public } \\
\text { ownership }\end{array}$ & $\begin{array}{c}\text { Market } \\
\text { structure }\end{array}$ & $\begin{array}{c}\text { Vertical } \\
\text { integration }\end{array}$ & $\begin{array}{c}\text { Price } \\
\text { controls }\end{array}$ \\
\cline { 2 - 6 } Gas & $\mathrm{X}$ & $\mathrm{X}$ & & & \\
Electricity & $\mathrm{X}$ & $\mathrm{X}$ & $\mathrm{X}$ & $\mathrm{X}$ & \\
Post & $\mathrm{X}$ & & & & $\mathrm{X}$ \\
Telecommunications & $\mathrm{X}$ & $\mathrm{X}$ & & $\mathrm{X}$ & \\
& $\mathrm{X}$ & $\mathrm{X}$ & & $\mathrm{X}$ & \\
& & $\mathrm{X}$ & $\mathrm{X}$ & & \\
\hline
\end{tabular}


Table 12. Product market regulatory reform in selected OECD countries

Time series regulatory indicators ${ }^{1}$

(scale 0-6 from the least to the most restrictive)

\begin{tabular}{lccccccc}
\hline & 1978 & 1982 & 1988 & 1993 & 1998 & $1998-1978$ & $\begin{array}{c}\text { Percentage } \\
\text { change }\end{array}$ \\
\cline { 2 - 8 } Australia & 4.5 & 4.5 & 4.2 & 3.3 & 1.6 & -2.9 & -0.65 \\
Austria & 5.2 & 5.1 & 4.5 & 3.9 & 3.2 & -2.0 & -0.39 \\
Belgium & 5.5 & 5.5 & 5.0 & 4.3 & 3.1 & -2.4 & -0.43 \\
Canada & 4.2 & 4.2 & 2.8 & 2.6 & 2.4 & -1.9 & -0.44 \\
Denmark & 5.6 & 5.5 & 5.5 & 4.0 & 2.9 & -2.7 & -0.48 \\
Finland & 5.6 & 5.5 & 4.8 & 4.0 & 2.6 & -3.0 & -0.53 \\
France & 6.0 & 5.9 & 5.7 & 4.7 & 3.9 & -2.1 & -0.35 \\
Germany & 5.2 & 5.2 & 4.7 & 3.8 & 2.4 & -2.8 & -0.54 \\
Greece & 5.7 & 5.7 & 5.7 & 5.5 & 5.1 & -0.6 & -0.10 \\
Ireland & 5.7 & 5.7 & 5.1 & 4.8 & 4.0 & -1.7 & -0.29 \\
Italy & 5.8 & 5.8 & 5.8 & 5.3 & 4.3 & -1.5 & -0.25 \\
Japan & 5.2 & 5.2 & 3.9 & 3.2 & 2.9 & -2.3 & -0.44 \\
Netherlands & 5.3 & 5.5 & 5.5 & 4.1 & 3.0 & -2.4 & -0.44 \\
New Zealand & 5.1 & 5.1 & 3.6 & 2.2 & 1.4 & -3.7 & -0.73 \\
Norway & 5.0 & 5.0 & 4.3 & 3.2 & 2.5 & -2.5 & -0.49 \\
Portugal & 5.9 & 5.9 & 5.4 & 4.9 & 4.1 & -1.8 & -0.30 \\
Spain & 4.7 & 4.7 & 4.6 & 4.2 & 3.2 & -1.5 & -0.31 \\
Sweden & 4.5 & 4.4 & 4.2 & 3.5 & 2.2 & -2.3 & -0.51 \\
Switzerland & 4.5 & 4.5 & 4.5 & 4.4 & 3.9 & -0.6 & -0.14 \\
United Kingdom & 4.3 & 4.2 & 3.5 & 1.9 & 1.0 & -3.3 & -0.76 \\
United States & 4.0 & 3.3 & 2.5 & 2.0 & 1.4 & -2.7 & -0.66 \\
\hline
\end{tabular}

1. Simple averages of indicators for 7 industries : gas, electricity, post, telecoms, air transport, railways, road freight. Depending on the industry the following dimensions have been included : barriers to entry, public ownership, market structure, vertical integration, price controls.

Source: Nicoletti and Scarpetta (2001).

60. For illustrative purposes, Figure 6 plots employment rates (total and for the non-agricultural business sector) in the OECD countries in 1998. It shows significant differences in the share of the working-age population which is employed, especially in the non-agricultural business sector: in the latter it ranges from less than 40 per cent in Greece to almost 65 per cent in Japan. These differences are related to overall labour market conditions in different countries, which also affect the decision of certain groups (youths, women in particular) to enter the labour market, as well as to the role of the state as an employer in the economy. There have also been different trends over time. North American countries, Japan, the United Kingdom, the Netherlands and some other smaller countries in Europe have shown a positive trend over the past two decades. In contrast, some of the Nordic countries have shown a significant fall in the early 1990s and most other European countries have shown stable or slightly declining trends. 
Figure 6. Employment rates ${ }^{1}, 1998$

(Percentage of total working-age population)

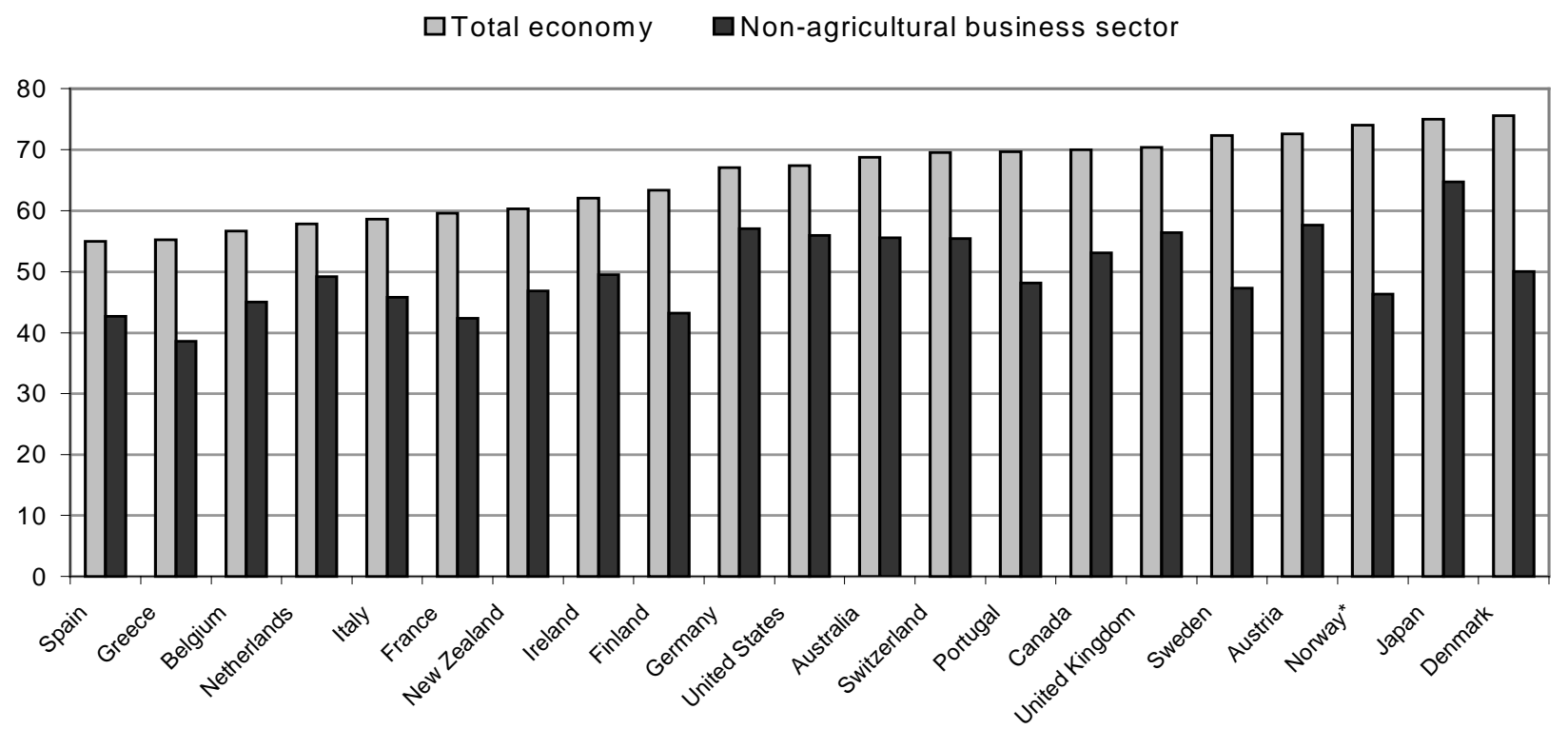

1. Countries are ranked from left to right from the lowest to the highest employment rate (total economy).

* Excludes off-shore activities.

61. How do these patterns of employment relate to regulations in the product and labour markets? Figure 7 relates the indicators of product market regulation to non-agricultural business-sector employment rates. Agricultural employment is not considered in the figure given the large proportion of self-employed in that sector who are only marginally affected by the product market regulations included in the summary indicators. There appears to be a negative cross-country relationship between product market regulation and employment rates, which is of comparable strength considering either the 1998 economy-wide measure of regulation or the time-series index (for 1998).

62. Moving away from simple bivariate correlations, a reduced-form model of non-agricultural employment based on the standard Layard-Nickell-Jackman (1991) framework was estimated. ${ }^{62}$ Employment rates were related to the (static) economy-wide and time-series indicators of the stringency of product market regulations controlling for a number of other policy and institutional factors that have been identified in the literature (for an exhaustive review see: OECD, 1994a, 1994b, 1999b; Nickell and Layard, 1999) as contributing to the equilibrium level of employment (unemployment). Here, only those for which data exist for a significant number of countries over time were considered: $i$ ) an indicator of the average (gross) unemployment benefit replacement rate (average of different duration and family conditions of the unemployed person); ii) the system of wage bargaining including the union density (the proportion of workers who are member of trade unions) and

62. The essential features of this framework are an upward sloping wage-setting schedule, based on the assumption that real wages are the results of a bargaining process between employers and employees, who are able to exert some market power, combined with a downward sloping labour demand schedule. The labour demand schedule is influenced by product market conditions, while the wage-setting schedule is influenced by wage-push factors, including labour market policies, the strength of workers in the wage bargaining process and, more generally, the institutional framework of the labour and product markets. 
the form of bargaining: ${ }^{63}$ iii) the level of taxes on the use of labour; ${ }^{64}$ and $i v$ ) the summary indicator of the strictness of EPL. To test for the hypothesis that only the business-sector employment rate is affected by the above policies and institutions, the public employment rate was included among the regressors: a unitary coefficient on this variable would fully justify the interpretation of coefficients as relating to effects on employment in the business sector. The output gap was also included to control for cross-country asymmetries and time-series changes in business-cycle conditions. ${ }^{65}$ Finally, all equations include country-specific effects that capture the influence of omitted variables on cross-country differences in employment rates.

63. The high correlation between the (static) economy-wide indicator of product market regulation and the indicator of EPL (highlighted in Nicoletti et al. 1999) makes it difficult to identify their respective contribution to employment outcomes. On the other hand, the time-varying product market indicator has a more limited coverage and may not fully take into account the details of the complex set of product market regulations. Thus, three separate estimation procedures were attempted: $i$ ) a random-effects specification including the (static) economy-wide product market indicators; ii) a two-stage approach in which the country-specific effects estimated from a specification excluding the product market regulation indicators are regressed on the economy-wide indicators of product market regulation; and iii) a standard panel data estimation procedure using the time-varying indicator of product market regulations. The estimation results were qualitatively similar in the three specifications, but considerably sharper in the regression using the time-varying regulatory indicator, which deals more effectively with the multicollinearity problem highlighted above. ${ }^{66}$ Therefore, in the following the focus will be on the specification in which regulatory developments are measured over time (results concerning the other model specifications can be found in Annex 2).

63. In the regressions, the variables referring to the centralisation/co-ordination of wage bargaining indicate the effects of intermediate or high centralisation/co-ordination with respect to that of decentralised systems. The distribution of countries according to the different aspects of collective bargaining and changes over time is presented in Elmeskov et al. (1998).

64. The tax wedge on the use of labour is the ratio of (employers' and employees') social security contributions and income taxes over total labour costs (employers' social security contributions plus gross wages). It should be stressed that the tax wedge may have an impact on equilibrium employment only in the presence of market imperfections. For example, workers may be able to resist offsetting wage cuts in a collective bargaining framework; unemployment benefits are in some cases fixed or subject to floors and ceilings which weaken their relationship with earnings; and non-labour income effects may be important (Phelps, 1994; Pissarides, 1998).

65. The gap variable is defined as the proportional difference between actual and potential output, where the latter is from the OECD Economic Outlook. The assumption of an identical parameter for the gap variable across all cross-sectional units does not affect significantly the estimated coefficients for the other explanatory variables. An alternative equation with country-specific coefficients for this variable produced similar results. Results remained unchanged also in another specification where the gap variable was instrumented with its lagged value to account for potential endogeneity problems induced by the simultaneous determination of employment and output over the business cycle.

66. The two-stage approach does not solve the problem of multicollinearity between the product market and EPL indicators arising in random-effects regressions. The first-stage estimates of the EPL coefficient may partially reflect the effects of the omitted product market regulation variables, affecting the estimates of the countryspecific fixed effects as well as their correlation with the product market indicators. Using the time-series indicator for product market regulations is a way to escape these estimation problems, though at the price of a less detailed account of regulatory environments. 
Figure 7. Employment rates in non-agricultural business sector and regulations, 1998
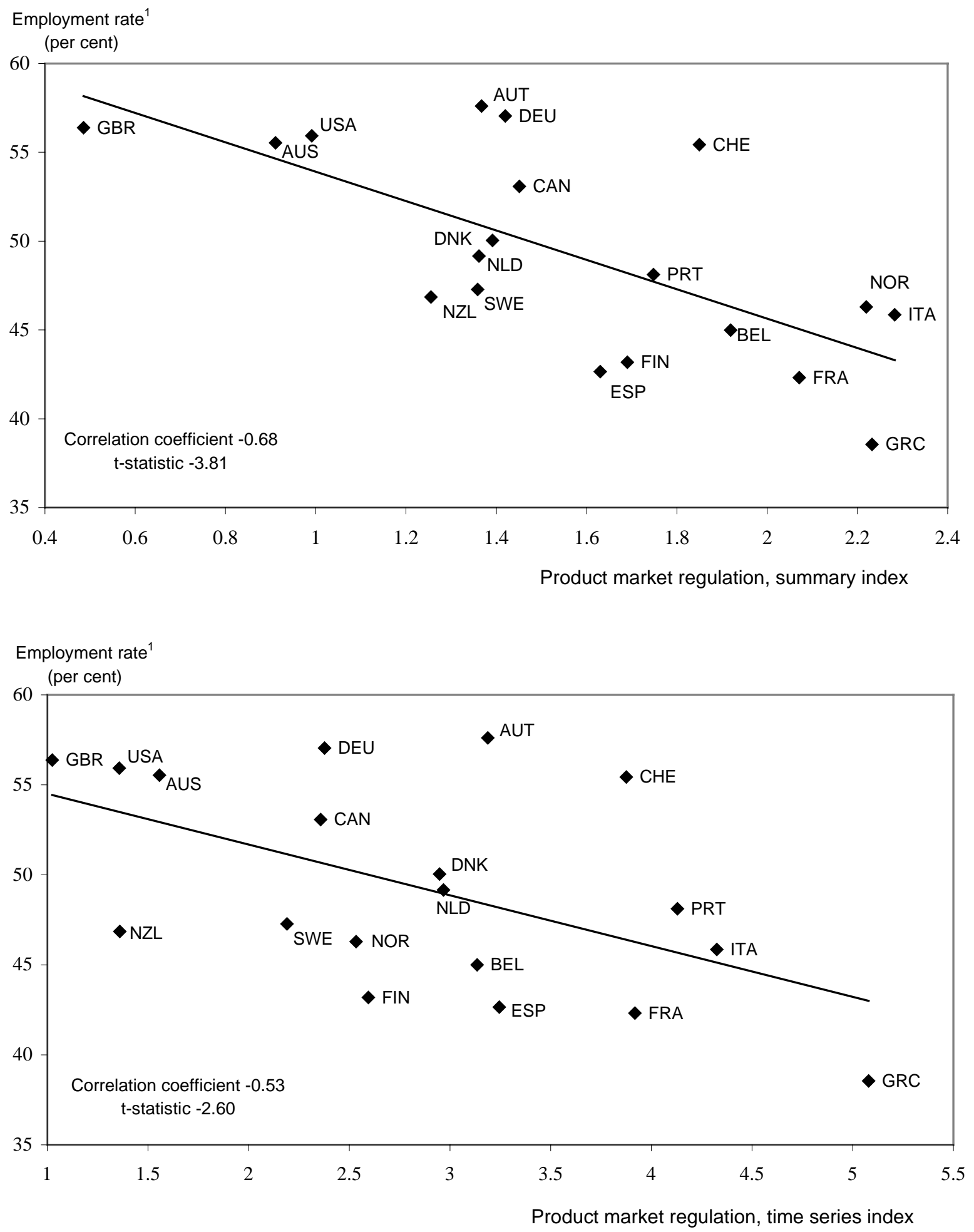

1. Non-agricultural business sector. 


\section{$\mathrm{ECO} / \mathrm{WKP}(2001) 38$}

64. Table 13 summarises the estimation results. ${ }^{67}$ As for the effects of labour market policies and institutions, the findings are only partly consistent with those of, inter alia, Nickell and Layard (1999), Elmeskov et al. (1998) and Nicoletti et al. (2001), most likely in part due to differences in country coverage and sample period and the choice of the dependent variable as well as data revisions. The significance of individual policy and institutional variables often depends on model specification, and the overall evidence concerning the impact of income support systems, tax wedges and bargaining systems on employment rates is somewhat weaker, while the estimated effect of unionisation is consistently stronger. ${ }^{68}$ On the other hand, in line with previous findings, the regression results point to a significant and negative impact of EPL on employment rates, with the impact being stronger and statistically more significant in countries with an intermediate degree of centralisation/co-ordination (where sectoral wage bargaining is predominant without co-ordination) ${ }^{69}$

65. Turning to product-labour market interactions, anticompetitive product market regulations are estimated to have a negative and highly significant impact on the employment rate in the specification using the time-series regulatory indicator. The significance and the size of the coefficient estimates of the other variables are little affected by the inclusion of the time-series indicator of regulatory reform, with two main exceptions: the coefficient of EPL, whose size is halved relative to results in the basic specification excluding product market regulation; and the coefficient on the tax wedge which is now statistically significant. This points to the importance of properly specifying the equation due to important interactions between the different explanatory factors. Finally, it is noteworthy that product market regulations curbing competition appear to be less harmful for employment in situations characterised by corporatist labour market regimes, where product market rigidities may be partially compensated by co-ordination/centralisation of bargaining mechanisms; for example by reducing the extraction of rents in wage premia.

\section{Conclusions on employment}

66. Thus, controlling for a number of policy and institutional factors affecting the labour market, it is possible to detect significant effects of product market regulation on the level of non-agricultural employment rates of OECD countries. On balance, the regression results suggest that product market competition has beneficial effects for employment, at least in the long run. Given the negative employment effects of strict hiring and firing rules also identified, regulatory reforms in both the product and labour markets appear to be needed to raise significantly employment rates in many OECD countries.

67. These conclusions are highlighted in Figure 8 that describes the estimated relative contributions of product and labour market policies to the explanation of differences in employment rates among OECD countries. ${ }^{70}$ As expected, the direct impact of labour market policies is largely dominant in all countries, but product market regulation often explains a significant part of the deviations of employment rates from the

67. Diagnostic analysis revealed the presence of significant outliers in the data set that consistently affected the standard error of the regression and/or the estimated coefficients. The outliers have been identified using studentised residuals and leverage values statistics. The observations removed from the sample are: 1985 for Spain; 1998 for Ireland and Japan; 1988 for Norway; 1994 for New Zealand.

68. The estimated negative impact of unemployment benefits and tax wedges on employment rates is not robust to changes in model specification (e.g. the introduction of interaction terms or the time-series of product market regulation), and the hump-shaped relationship between employment rates and the degree of centralisation/coordination (Calmfors and Driffill, 1988) is only weakly supported by the data. Thus, the relationship between the employment rate and unemployment insurance and bargaining systems is much less clear-cut than for the unemployment rate.

69. The null hypothesis of a unitary coefficient on the public-employment rate cannot be rejected at the conventional level, suggesting that the interpretation of the results as reflecting behaviour in the business sector is justified.

70. The figure is based on results from the fixed-effects specification with time-varying product market regulation and no interaction terms. 
ECO/WKP(2001)38

Table 13. Labour and product market determinants of the non-agricultural employment rate, 1982-1998 (Fixed effects regressions)

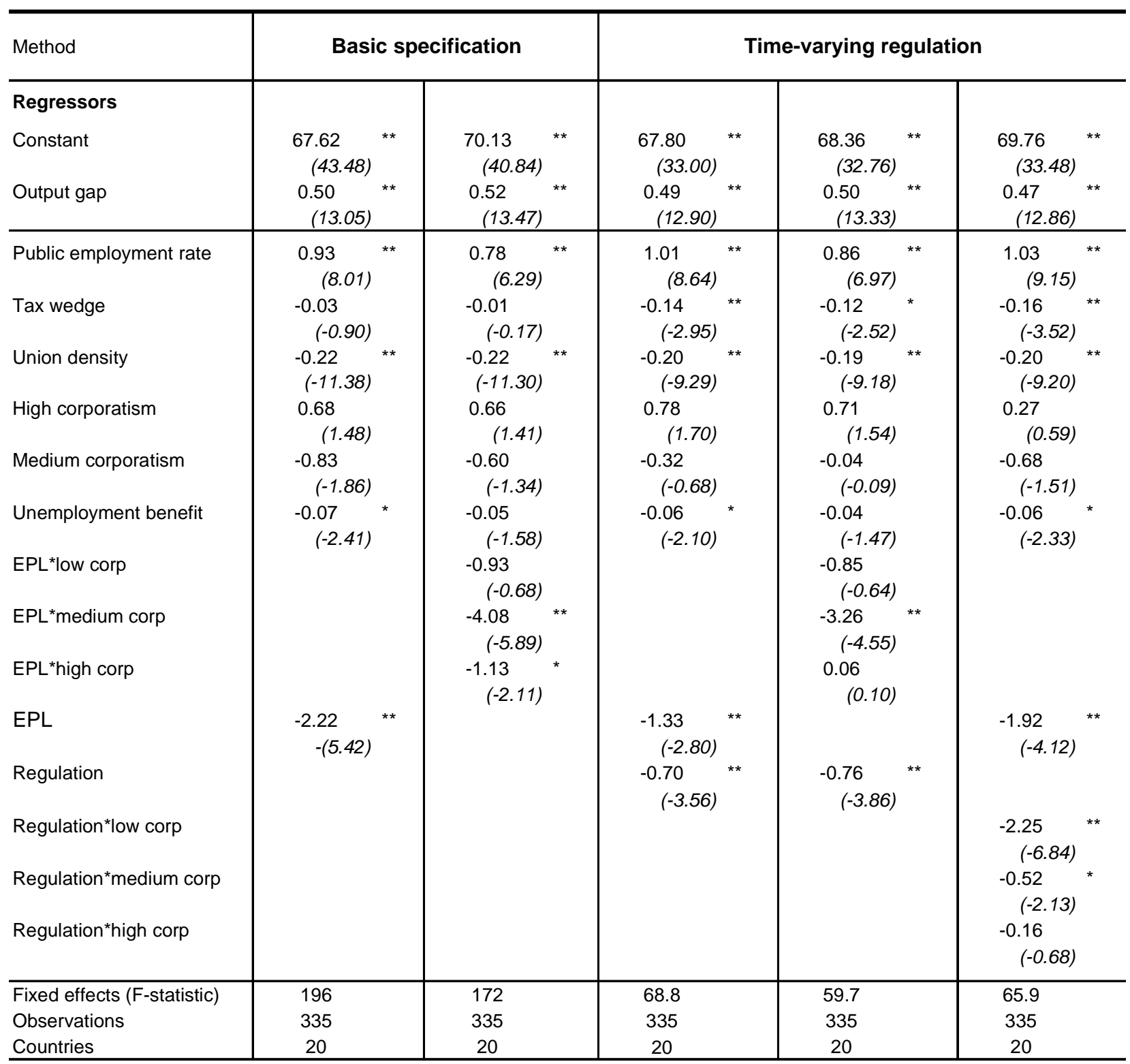

Note: T-statistics are in brackets.

${ }^{*},{ }^{* \star}$ denote significance at the $5 \%$ and $1 \%$ level, respectively.

Source: Nicoletti and Scarpetta (2001).

OECD average. For instance, in the United States and the United Kingdom liberal product market regulation is estimated to have had an impact on employment rates that is comparable to that of low tax wedges. In several other countries (such as Greece, Portugal, Italy and France), the empirical estimates imply that product market restrictions may play a role comparable to labour market policies in explaining low employment rates relative to the OECD average. 
Figure 8. The contribution of product and labour market policies to differences in employment rates among $\mathrm{OECD}$ countries ${ }^{1}$

(Percentage deviations from OECD average)

$\square$ EPL and benefit policies $\quad \square$ Tax wedge $\quad \square$ Product market regulation
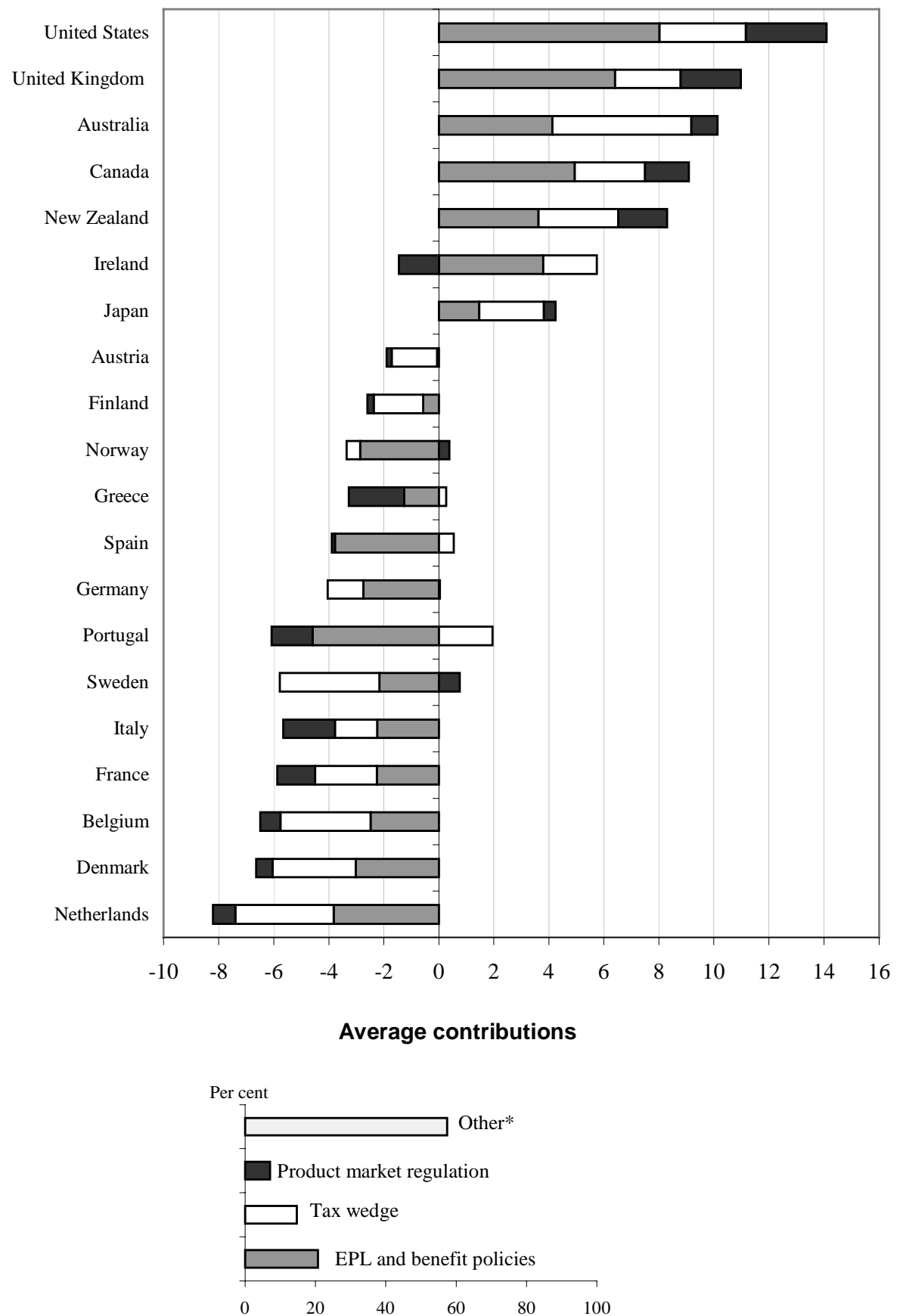

1. Based on the fixed-effects specification with time-varying regulation and no interaction terms.

* Not shown in the figure. Includes effects of bargaining systems, unionisation, output gaps and other unexplained factors (country-specific effets and residuals). 


\section{Effects of market interactions on insecurity and inequality}

68. Governments pursue security and equity goals in setting regulatory policy, in addition to the efficiency goals emphasised in Sections II-III. Furthermore, the perception that efficiency-oriented regulatory reforms may result in increased insecurity and inequality appears to play an important role in the political economy of regulation [Agell (1999)]. In response to these concerns, this section analyses the effects of product and labour market regulations and institutions on insecurity and inequality. Improved understanding of these potential links, including possible trade-offs between the goals of efficiency, security and equity, should help in making more informed choices when setting regulatory policy. Political support for efficiency-enhancing policies might also be reinforced if it could be shown that they do not have important adverse impacts on security and equity goals, or -- at a minimum -- have been designed so as to minimise these impacts.

69. As in Sections II-III, the main emphasis is placed on the cross-market effects of regulatory policy, in this case, how product market regulations might influence the extent of employment insecurity and earnings inequality. Due to the nature of the data which are available for analysis, only the long-run effects of product market regulations are considered, despite the potential importance of transitional dislocations resulting from deregulation [Card (1998)]. With the notable exception of the impact of trade liberalisation on earnings inequality [OECD (1997a); Pizer (2000)], these long-run effects have received little attention from researchers. Own-market effects are also briefly considered, despite their having received more attention in prior research. ${ }^{71}$ Controlling for cross-market effects should make it possible to estimate own-market effects more accurately and to assess whether interaction effects between product market and labour market regulations are important.

70. The empirical analysis in this section is closely related to that in the preceding section. The main differentiating characteristic of the current section is the focus on different performance criteria, namely employment security and earnings equity. Indeed, one of the key questions to be analysed in this section is whether cross-market effects are potentially important for insecurity and inequality. That is, whether the assessment of policy choices related to product market regulations generally should encompass an analysis of the implications for insecurity or inequality, or such effects typically can be ignored as being relatively minor.

71. The key practical difficulty confronting this analysis is the need to assemble measures of employment insecurity and earnings inequality that are reasonably comparable for a significant number of OECD countries and available at a level of industrial disaggregation that corresponds to that for which the indices of product market regulations have been assembled. As discussed below, the measures that have been assembled have two important limitations. First, these measures do not reflect fully the complexity of the underlying concepts of insecurity and inequality. Second, the coverage of countries and industries is not as broad as for the analysis in Sections II-III. Accordingly, the empirical analysis in this section should be viewed as providing a preliminary assessment of the importance of the potential links between product market deregulation and increased insecurity or inequality, rather than precise quantitative estimates of policy trade-offs.

\subsection{Insecurity}

72. How might product market regulations affect insecurity? As discussed in Section III, prior research has focussed on the implications of product market regulations and competition for labour market performance at the aggregate and sectoral levels (e.g. the effects on aggregate employment and industry wage premia), rather than their implications for the employment insecurity of individual workers. Nevertheless, this research is suggestive of several channels through which product market regulations could affect employment insecurity. Potentially important linkages between product market competition and insecurity, include:

71. Effects of labour market regulations on insecurity and inequality that have received attention from prior researchers include the impact of EPL on employment and earnings stability [Bertola (1999); OECD (1998b); Pissarides (2001)] and the impact of collective bargaining on wage inequality [Blau and Kahn (1999); OECD $(1997 a)]$. 
- A regulatory structure conducive to vigorous product market competition might reduce the extent to which employers are willing or able to offer stable jobs. Hicks (1935) famously observed that "the best of all monopoly profits is a quiet life," and workers employed by firms with substantial market power may also enjoy greater stability in their careers. For example, greater market power may mean that firms and - by extension - their workforces are less exposed to adverse demand shocks (e.g. loss of market share due to heightened competition from new entrants to the industry).

- The earnings losses associated with redundancies might be reduced by regulatory reforms that cause the equilibrium unemployment rate to decline. The latter result occurs in some recent theoretical models [e.g. Blanchard and Giavazzi (2001); Gersbach and Schniewind (1999); Layard and Nickell (1990)]. It should be noted, however, that these models do not analyse how the predicted change in the unemployment rate affects the duration of unemployment following job loss. Nonetheless, the strong empirical association between lower unemployment rates and lower unemployment durations [Machin and Manning (1999)] suggests such a link, as does the finding that displaced workers fare better when the unemployment rate is lower [Farber (2001)].

- The wage premia received by workers in heavily regulated industries (Section III) may cause workers displaced from these industries to experience especially long spells of unemployment. Such workers may prefer to queue for new jobs in the same industry, rather than searching for jobs in other sectors where there may be more vacancies, because changing industries is associated with large reductions in pay [Kletzer (1998); see also the discussion of "wait unemployment" in Box 2].

- Amable and Gatti (2001) analyse a general equilibrium model that illustrates several of these channels: product market deregulation results in a higher rate of job loss, but also shorter unemployment durations. It is not clear, however, whether these results are robust to alternative assumptions about wage setting or labour mobility. Nonetheless, the Amable and Gatti model confirms that product market regulations may affect insecurity through influencing both the incidence of job loss and the size of the income losses that result. It also suggests that interaction effects may be important. In particular, the effect of product market regulations on labour turnover may depend on the nature of wage-setting institutions. ${ }^{72}$

\section{Measures of insecurity}

73. As used here, "insecurity" refers to the risk that a worker will experience a significant fall in earnings due to involuntary job loss. ${ }^{73}$ The expected cost of job loss for a worker who is currently employed can be expressed as the product of the probability of job loss and the mean cost of losing a job:

$$
E\left(\cos t_{-} o f \_j o b_{-} l o s s\right)=\operatorname{Pr}\left(j o b_{-} \text {loss }\right) * E\left(\cos t \mid j o b_{-} \text {loss }\right)
$$

72. Many of the static models in the theoretical literature also imply that the impacts of product market regulations on aggregate employment and unemployment are strongly influenced by wage-setting institutions [Nickell (1999)]. Similarly, the empirical literature suggests that a portion of the rents that accrue to firms with market power typically are passed on to unionised workers in the form of higher wages, but that rent capture is much less evident for non-unionised workers.

73. Although not analysed here, earnings can also fall in the absence of job loss (e.g. labour income will fall for workers on continuing jobs who experience declines in hours worked or pay rates). Although nominal wage cuts appear to be rare, workers covered by incentive pay schemes (e.g. profit-sharing) may face a greater risk of earnings declining while remaining with the same employer. 
where job loss is intended to refer to separations that are involuntary from the perspective of the worker. The (conditional) cost of job loss will tend to be higher in labour markets where the duration of non-employment is greater and/or displaced workers have to accept larger pay cuts to become re-employed.

74. Discussions of employment insecurity often consider only the risk of job loss (i.e. the first right-handside term in equation 1). However, the expected cost of job loss provides a more comprehensive measure of the extent to which job displacement creates insecurity for the earnings capacity and living standards of workers and their dependants. Weighting the probability of experiencing a redundancy by the economic consequences of job loss may be especially important for making inter-industry and international comparisons of insecurity, which is the strategy used here to analyse the impact of product and labour market regulations on insecurity. This will be the case if there is a trade-off between the frequency of job loss and the resulting costs (e.g. if more competitive markets are characterised by relatively high rates of involuntary job loss, but also by relatively quick re-employment at similar wages). ${ }^{74}$

75. Panel data that follow workers over an extended period of time are required to measure the incidence and costs of job loss in a fully satisfactory manner. Unfortunately, attempts to construct such measures using three years of longitudinal data from the European Panel Household Survey (ECHP) were to no avail. ${ }^{75}$ Accordingly, most of the insecurity measures analysed here are derived from labour force surveys which offer superior country coverage and larger samples for calculating measures that are disaggregated by industry. These proxy measures are somewhat crude, but allow an initial assessment to be made of whether product and labour market regulations affect either the incidence of job loss or the earnings lost while searching for a new job.

76. Table 14 provides an overview of the six insecurity measures used in the analysis. The first three measures provide information about the extent of worker turnover, which serve as proxy indicators of the probability of job loss (i.e. the first right-hand-side term in equation 1). An important limitation of these measures is that they do not differentiate between involuntary job loss and voluntary quits. Note also that the first measure (i.e. the share of workers hired in the previous year) may also reflect ease of re-entry. The fourth measure is the incidence of long-term unemployment, which serves as a proxy for the magnitude of earnings losses following job loss (i.e. the second right-hand-side term in equation 1). However, this measure accounts neither for any differences in unemployment duration between job losers and other job searchers nor for any earnings losses once re-employed. The final two indicators are proxy measures for the expected cost of job loss (i.e. the combined effect of the probability and cost of job loss): the fifth measure is the rate of job loss leading to long-term unemployment (i.e. job loser's who are still unemployed a year later, as a share of total employment) $;{ }^{76}$ and the sixth measure is a subjective appraisal by workers of job security on their current job. While none of these six measures represents a fully satisfactory estimate of the corresponding term(s) in equation 1, they should be sufficiently positively correlated with the desired concepts to provide valid qualitative evidence. $^{77}$

74. The two-sided search equilibrium models surveyed by Mortensen and Pissarides (1999a,b) provide a unified framework for analysing how the incidence and duration of unemployment are affected by policy changes, such as the introduction of EPL [Pissarides (2001)]. A comparison of displaced workers in Belgium and Denmark provides evidence that stricter EPL is, in fact, associated with a lower job loss rate and longer unemployment durations [Albaek et al. (1998)].

75. Only small samples of job losers are observed for any given industry-country combination and the effects of job loss on future employment and earnings can only be observed over a short period of time.

76. Conceptually, this measure corresponds most closely to the expected cost of job loss as defined in equation 1 . However, it is calculated from somewhat imprecise retrospective questions in the European Labour Force Survey.

77. This supposition is probably most questionable for the three measures of labour turnover because a depressing effect of product or labour market regulations on the quit rate could be mistakenly interpreted as a fall in the job loss rate. For example, if product market regulation results in a positive wage premium being paid in a particular 
ECO/WKP(2001)38

Table 14. Measures of insecurity used in the analysis

\begin{tabular}{|c|c|c|c|c|}
\hline Description of variable & Source of data & $\begin{array}{l}\text { Industry } \\
\text { coverage }^{1}\end{array}$ & $\begin{array}{l}\text { Country } \\
\text { coverage }\end{array}$ & Comments on interpretation \\
\hline \multicolumn{5}{|l|}{ Measures of the risk of job loss: } \\
\hline $\begin{array}{l}\text { 1. Workers with a year or } \\
\text { less of job tenure (per cent } \\
\text { of total employment) }\end{array}$ & $\begin{array}{l}\text { Labour force } \\
\text { survey data. }\end{array}$ & $9(5)$ & 15 & $\begin{array}{l}\text { Higher values indicate greater worker turnover which is } \\
\text { used as a proxy for an increased probability of job loss. }\end{array}$ \\
\hline $\begin{array}{l}\text { 2. Average job tenure } \\
\text { (years) }\end{array}$ & $\begin{array}{l}\text { Labour force } \\
\text { survey data. }\end{array}$ & $9(5)$ & 16 & $\begin{array}{l}\text { Higher values indicate greater job stability which is used } \\
\text { as a proxy for a decreased probability of job loss. }\end{array}$ \\
\hline $\begin{array}{l}\text { 3. Workers with temporary } \\
\text { jobs (per cent of total } \\
\text { employment) }\end{array}$ & $\begin{array}{l}\text { Labour force } \\
\text { survey data. }\end{array}$ & $9(5)$ & 17 & $\begin{array}{l}\text { Higher values used as a proxy for a greater share of } \\
\text { workers facing imminent job loss. }\end{array}$ \\
\hline \multicolumn{5}{|l|}{ Measures of the cost of job loss: } \\
\hline $\begin{array}{l}\text { 4. Incidence of long-term } \\
\text { unemployment (percent of } \\
\text { all unemployed who have } \\
\text { been searching for a year or }\end{array}$ & $\begin{array}{l}\text { Labour force } \\
\text { survey data. }\end{array}$ & $13(13)$ & 13 & $\begin{array}{l}\text { Higher values indicate that earnings losses following job } \\
\text { loss are greater. However, no consideration is taken of } \\
\text { wages once re-employed. }\end{array}$ \\
\hline \multicolumn{5}{|c|}{ Measures combining the risk and cost of job loss: } \\
\hline $\begin{array}{l}\text { 5. Incidence of job losses } \\
\text { resulting in long-term } \\
\text { unemployment }\end{array}$ & $\begin{array}{l}\text { Labour force } \\
\text { survey data. }\end{array}$ & $13(13)$ & 13 & $\begin{array}{l}\text { Reflects both the rate of involuntary job loss and the } \\
\text { probability workers losing a job are still unemployed one } \\
\text { year later. Normalised as a relative rate by industry for the } \\
\text { regression analysis. }\end{array}$ \\
\hline $\begin{array}{l}\text { 6. Mean satisfaction of } \\
\text { workers with job security on } \\
\text { their current jobs }\end{array}$ & $\begin{array}{l}\text { European } \\
\text { Community } \\
\text { Household } \\
\text { Panel }\end{array}$ & $5(3)$ & 10 & $\begin{array}{l}\text { Workers appraisal of job security on their current jobs, } \\
\text { with higher values corresponding to greater satisfaction (1- } \\
6 \text { scale). }\end{array}$ \\
\hline
\end{tabular}

1. Number of service industries for which both the insecurity measure and the global index of product market regulation are available. The value in parentheses is the number of cases in which there is an exact match of industry definitions between the two variables. Regressions using only the exact-match industries give similar results to those also using industries where the match was approximate. (See Annex 2 for details.)

77. National average values of these six proxy measures of employment insecurity are plotted in Figure 9. Cross-country differences are considerable, with national comparisons differing somewhat between the different measures. The cross-country associations between these insecurity measures and the global index of the extent to which product market regulations restrict competition are also displayed. These bivariate associations are often weak, but offer suggestive evidence that stricter product market regulation may be associated with greater job security, as proxied by the tenure variables reported in the first two panels of Figure 9. However, many factors, in addition to product market regulation, that may account for international differences in labour turnover and employment insecurity have not been accounted for. ${ }^{78}$ The multivariate analysis which follows provides a clearer indication of whether product market regulations have a causal impact on labour turnover and insecurity.

industry (see Section III), that premium is likely to discourage quits, without necessarily implying any improvement in job security.

78. For example, the apparent link between less product market competition and less labour turnover shown in the first two panels in Figure 9 might reflect, in actuality, the depressing effect of stricter EPL on lay-offs, because countries with stricter EPL also tend to have more restrictive product market regulations [Nicoletti et al. (1999)]. 
Figure 9. Overall product market regulation and insecurity, 1998
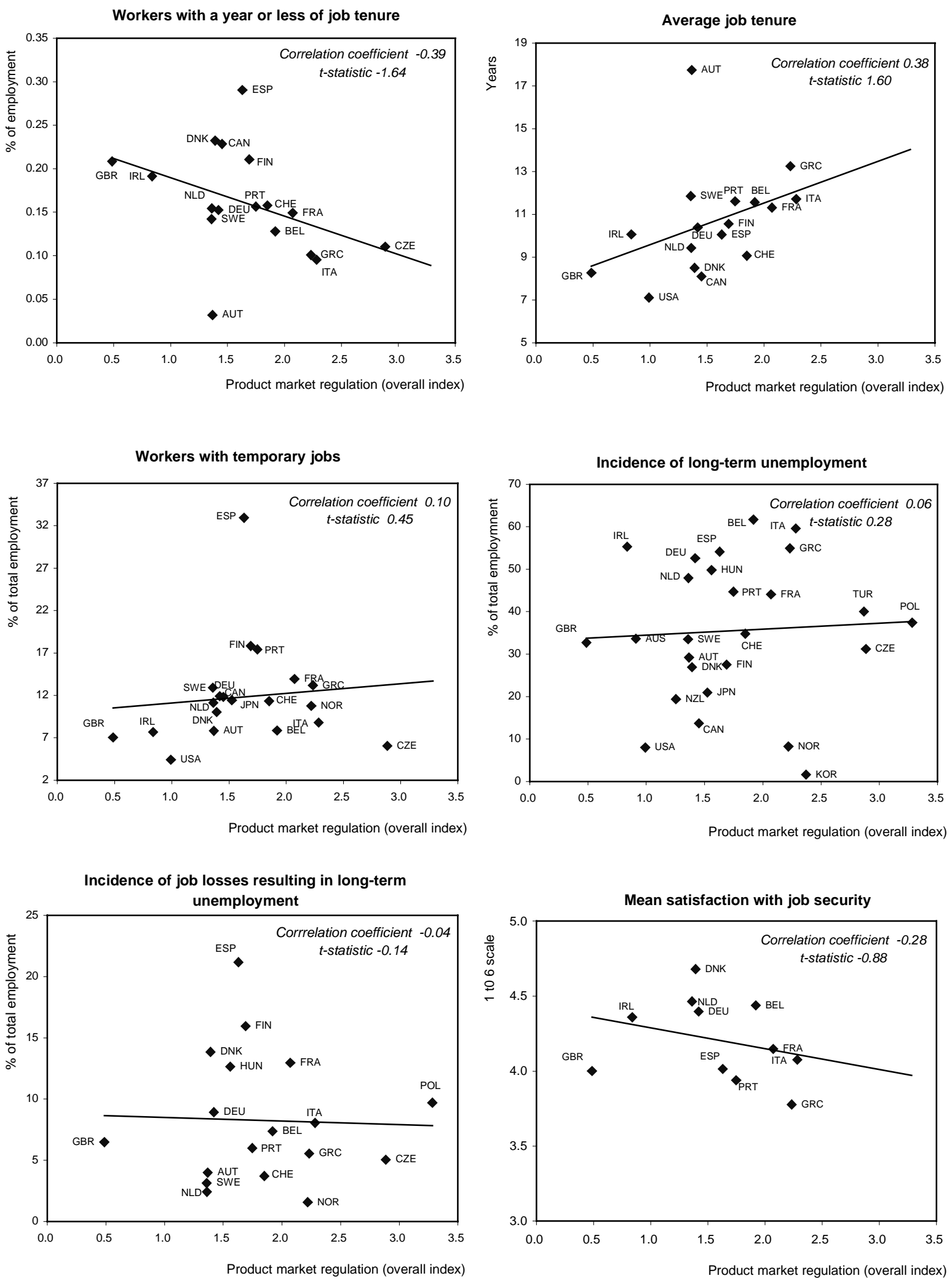


\section{$\mathrm{ECO} / \mathrm{WKP}(2001) 38$}

\section{Regression analysis}

78. Reduced-form regression models, similar to the panel models presented in Sections II-III, are used here to analyse the impacts of regulations and institutions on earnings insecurity at the end of the $1990 \mathrm{~s}^{79}$ The six proxy measures of insecurity are used as the dependent variables, while the regressor of greatest interest is the global index of product market regulations. Industry-specific values are used for both the measures of insecurity and the product market regulations. Several different approaches were tried to capture potential nonlinearities in the effect of product market regulations on insecurity. Models allowing the marginal effect of changes in the global index of product market regulations to differ, depending on whether the reference level of competition is high or low, performed best and are reported here. ${ }^{80}$ Two types of labour market variables were interacted with the global measure of product market regulations: $i$ ) measures of EPL strictness; and ii) measures of wage-bargaining structure (i.e. the level of centralisation and co-ordination in collective bargaining). Economic theory suggests that such interactions may be important, but these interactions did not perform well in the empirical analysis and are not reported here. ${ }^{81}$ The regression analysis also controls for three aspects of labour market regulations and institutions: EPL, union density and the generosity of unemployment insurance benefits. In order to control for business-cycle effects on labour turnover, the GDP gap is also included in the regression equation.

79. Estimation results are presented for a basic model, including the regulatory and institutional regressors, as well as for an augmented model that also controls for industry and country effects. As discussed in Section II, the augmented model may avoid misspecification biases by accounting for omitted variables that differ by industry or country. However, two problems related to the inclusion of industry and country effects in this analysis should be noted:

- Technological characteristics of industries that directly affect labour turnover may also be important determinants of inter-industry differences in product market regulations (e.g. the scale economies and capital intensity of the electric, gas and water supply industry). As a result, caution is called for when attempting to differentiate between the effects of regulatory and technological factors on employment security.

- Due to data limitations, it was sometimes impossible to estimate a model including both industry and country effects. In such cases, only industry effects are estimated since they tend to be more statistically significant and to have the greatest effect on the coefficients of the variables measuring product and labour market regulations and institutions. ${ }^{82}$

80. Table 15 presents the regression results using the six measures of employment insecurity. In all cases, the industry and country effects are statistically significant suggesting that the augmented model is more

79. Regression results are reported for panels of service industries using data for 1998. Cross-sectional regressions, using aggregate national values, and panel regressions for manufacturing industries both proved uninformative due to limitations in the available data. (See Annex 2 for a fuller discussion.)

80. The effect of product market competition on insecurity is modelled by a linear spline with a single kink-point at the sample median value of the global index for product market regulations.

81. Most of the interaction variables are statistically insignificant and their inclusion in the model exacerbates the problem of multicollinearity. However, there is some evidence that strict EPL strengthens the positive association shown in Figure 9 between stricter product market regulation and greater job stability. By contrast, the positive association between product market regulation and long-term unemployment appears to be stronger when EPL is less strict.

82. The relatively small number of countries and industries for which insecurity measures could be matched to the variables measuring product and labour market regulations and institutions means that only a modest number of observations are available for statistical estimation. The estimation problems created by low degrees of freedom are exacerbated by three of the regressors having only a country dimension and substantial multicollinearity among some of the regressors. 
appropriate than the basic model. However, the Hausman test indicates a possible misspecification related to the country random effects for the augmented model explaining the share of temporary jobs. Re-estimating this model while omitting the country random effects has very little effect on the estimation results. ${ }^{83}$

Table 15. Policies, institutions and insecurity ${ }^{1}$

Results for panel regressions of service industries

Panel A. Measures of the risk of job loss

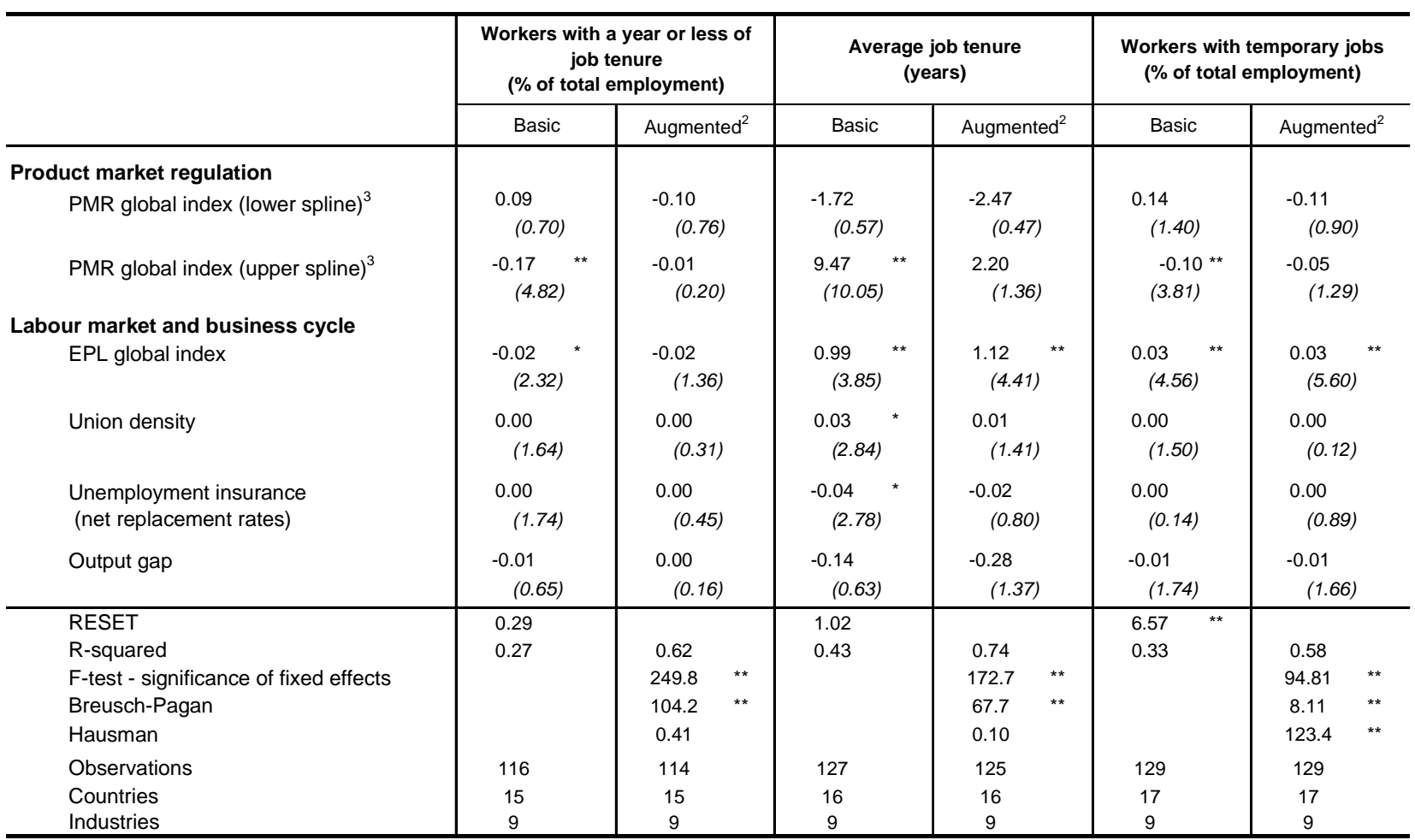

1. See Table 14 for the definitions of the insecurity measures (i.e. the dependent variables).

2. Basic model augmented to include industry fixed effects and country random effects. It is estimated by GLS.

3. The effects of the global index for PMR are modeled as linear splines with a single kink point.

Note: ${ }^{*},{ }^{* \star}$ denote significance at the $5 \%$ and $1 \%$ level, respectively. All equations include a constant. T-statistics in parentheses.

Samples are adjusted for outliers based on the Welsch distance cut-off (Chatterjee and Hadi, 1988).

Basic model is estimated by OLS, the standard errors being adjusted for clustering.

83. The data are not adequate to estimate a model including fixed effects for both industry and country. 


\section{$\mathrm{ECO} / \mathrm{WKP}(2001) 38$}

81. The estimation results for the three proxy measures of the risk of job loss suggest that regulations reducing product market competition may sometimes result in greater job security (Panel A of Table 15). However, this effect appears to be limited to the most regulated industries (only being supported by the upperspline coefficients). Furthermore, the estimated effects are smaller and statistically insignificant when industry and country effects are introduced into the model. This confirms that it is difficult to assess whether the association between strict product market regulations and high job security is, in part, causal or is fully accounted for by other characteristics of tightly-regulated industries. Should the upper-bound estimates provided by the basic model be valid, the impact of product market regulations would be large enough to be of considerable importance. Starting at the median value, a one standard deviation increase in the regulation index implies that average tenure increases by approximately one and one-half years (or 0.45 of a standard deviation). However, the augmented model implies an effect that is less than one-fourth as strong and is consistent with there being no effect at all. It should also be noted that any increase in job stability due to product market regulations appears to be limited to a few tightly-regulated industries, such as electric, gas and water supply, where public ownership is common and may lead employers to offer workers non-pecuniary rents, such as lifetime job guarantees (Section III).

82. Among the labour market variables, only EPL appears to have a systematic impact on the risk of job loss. Stricter EPL lowers overall worker turnover and raises average tenures, but also encourages an expansion in the share of workers on temporary contracts. ${ }^{84}$ Job security may be enhanced for workers with regular contracts (i.e. "insiders"), but diminished for workers unable to obtain "permanent" jobs (i.e. "outsiders"). These estimated effects are large enough to be economically important. For example, the EPL coefficients in the two models explaining average job tenure imply that a one standard deviation increase in the EPL strictness index implies that average tenure increases by a little more than one year (or 0.3 of a standard deviation).

83. Regression results for the dependent variables that reflect the cost of job loss are reported in Panel B of Table 15. The theoretical prediction that stricter product market regulations result in longer unemployment spells is only weakly supported for the most regulated industries. The results for the incidence of job losses resulting in long-term unemployment -- a measure reflecting both the risk of job loss and the duration of post-displacement joblessness -- are stronger, suggesting that the reduction in the risk of job loss associated with stricter product market regulations outweighs any increase in unemployment durations, generating a net decrease in employment insecurity ${ }^{85}$ This result is only significant when regulation is already tight, however. The estimation results using workers' subjective appraisals of job security suggest that employees in the industries subject to intermediate levels of regulation feel the most secure, ceteris paribus. ${ }^{86}$

84. Although stricter EPL on regular jobs creates an incentive for employers to circumvent these restrictions by expanding their use of temporary contracts, previous analysis by the OECD (1999c) was unable to verify such an effect across OECD countries.

85. The augmented model for average tenure provides only weak evidence that strict product market regulations lower the risk of job loss, since the t-statistic indicates that there is a nearly one-in-five probability that there is no such effect. However, the augmented model for the risk of job loss leading to long-term unemployment indicates a statistically significant effect of product market regulations in reducing the expected cost of job loss. Such an effect implies that at least one of the two right-hand-side components of equation 1 is also affected.

86. The coefficient on the lower spline for product market regulation in the augmented model implies that a one standard deviation in regulation - starting from a low level - would produce a 0.43 standard deviation increase in satisfaction with job security. However, increases in regulation above the median value cause job security to fall. 
ECO/WKP(2001)38

Table 15. Policies, institutions and insecurity ${ }^{1}$ (continued) Results for panel regressions of service industries

Panel B. Measures of the cost of job loss

\begin{tabular}{|c|c|c|c|c|c|c|c|}
\hline & \multicolumn{2}{|c|}{$\begin{array}{l}\text { Incidence of long-term } \\
\text { unemployment } \\
\text { (\% of total unemployment) }\end{array}$} & \multicolumn{2}{|c|}{$\begin{array}{l}\text { Incidence of job losses resulting } \\
\text { in long-term unemployment } \\
\text { (relative rate by industry) }^{2}\end{array}$} & \multicolumn{3}{|c|}{$\begin{array}{l}\text { Mean satisfaction with job } \\
\text { security (1-6 scale) }\end{array}$} \\
\hline & Basic & Augmented $^{3}$ & Basic & Augmented ${ }^{4}$ & Basic & Augmente & \\
\hline \multicolumn{8}{|l|}{ Product market regulation } \\
\hline PMR global index (lower spline) ${ }^{5}$ & $\begin{array}{c}-0.45 \\
(-2.40)\end{array}$ & $\begin{array}{l}-0.04 \\
(-0.09)\end{array}$ & $\begin{array}{l}0.79 \\
(1.35)\end{array}$ & $\begin{array}{l}1.51 \\
(1.60)\end{array}$ & $\begin{array}{l}-0.48 \\
(-1.17)\end{array}$ & $\begin{array}{l}1.86 \\
(2.57)\end{array}$ & \\
\hline PMR global index (upper spline) ${ }^{5}$ & $\begin{array}{l}0.15 \\
(1.30)\end{array}$ & $\begin{array}{l}0.31 \\
\quad(1.66)\end{array}$ & $\begin{array}{l}-1.17 \\
(-4.22)\end{array}$ & $\begin{array}{c}-0.68 * \\
(-2.04)\end{array}$ & $\begin{array}{l}-1.40 \\
(-1.43)\end{array}$ & $\begin{array}{r}-1.26 \\
(-1.05)\end{array}$ & \\
\hline $\begin{array}{l}\text { Labour market and business cycle } \\
\text { EPL global index }\end{array}$ & $\begin{array}{l}0.06 \text { (2.64) } \\
\text { * }\end{array}$ & $\begin{array}{l}0.06 \\
(4.14)\end{array}$ & & & $\begin{array}{l}-0.04 \\
(-0.99)\end{array}$ & $\begin{array}{l}-0.06 \\
(-1.53)\end{array}$ & \\
\hline Union density & $\begin{array}{l}0.00 \\
(0.08)\end{array}$ & $\begin{array}{l}0.00 \\
(-0.04)\end{array}$ & $\begin{array}{l}0.00 \\
(0.24)\end{array}$ & $\begin{array}{l}0.00 \\
(1.54)\end{array}$ & $\begin{array}{c}0.01 \\
(2.44)\end{array}$ * & $\begin{array}{l}0.00 \\
(2.17)\end{array}$ & \\
\hline $\begin{array}{l}\text { Unemployment insurance } \\
\text { (net replacement rates) }\end{array}$ & $\begin{array}{l}0.00 \\
(0.74)\end{array}$ & $\begin{array}{l}0.00 \\
\quad(1.55)\end{array}$ & & & $\begin{array}{l}0.02 \\
(2.57)\end{array}$ & $\begin{array}{l}0.02 \\
\quad(2.66)\end{array}$ & * \\
\hline Output gap & $\begin{array}{l}-0.03 \\
(-1.59)\end{array}$ & $\begin{array}{l}-0.03 \\
(-1.48)\end{array}$ & & & $\begin{array}{l}-0.10 \\
(-2.09)\end{array}$ & $\begin{array}{r}-0.08 \\
(-1.71)\end{array}$ & \\
\hline RESET & 2.17 & 1.90 & 0.40 & & 0.60 & 0.41 & \\
\hline R-squared & 0.18 & 0.29 & 0.10 & 0.59 & 0.45 & 0.63 & \\
\hline F-test - significance of fixed effects & & 95000 & & 178.2 & & 6.26 & ** \\
\hline Breusch-Pagan test & & & & 5.07 & & & \\
\hline Hausman & & & & 6.20 & & & \\
\hline Observations & 135 & 133 & 142 & 142 & 48 & 47 & \\
\hline Countries & 13 & 13 & 13 & 13 & 10 & 10 & \\
\hline Industries & 13 & 13 & 13 & 13 & 5 & 5 & \\
\hline
\end{tabular}

1. See Table 14 for the definitions of the insecurity measures (i.e. the dependent variables).

2. Regressors with no inter-industry variation within a country are not used for this dependent variable, since there cannot be common

effects across all industries in their relative risk of job loss.

3. Basic model augmented to include industry fixed effects. It is estimated by OLS, the standard errors being adjusted for clustering

4. Basic model augmented to include industry fixed effects and country random effects. It is estimated by GLS.

5. The effects of the global index for PMR are modeled as linear splines with a single kink point.

Note: ${ }^{* * *}$ denote significance at the $5 \%$ and $1 \%$ level, respectively. All equations include a constant. T-statistics in parentheses.

Samples are adjusted for outliers based on the Welsch distance cut-off (Chatterjee and Hadi, 1988).

Basic model is estimated by OLS, the standard errors being adjusted for clustering.

84. Consistent with earlier research, stricter EPL is significantly associated with an increased incidence of long unemployment spells, with a one standard deviation increase in EPL raising the long-term unemployment rate by 5 to 6 percentage points (or 0.3 of a standard deviation). This may explain why stricter EPL is not associated with greater worker satisfaction with job security on their current jobs. By contrast, more generous unemployment insurance benefits and higher union density do cause workers to report greater satisfaction with job security, perhaps because their families' incomes are better protected, should they lose their jobs. This effect is quite large. A standard deviation increase in the net replacement rate implies nearly a 0.6 standard deviation increase in the satisfaction index.

\section{Conclusions for insecurity}

85. Despite its preliminary character, this analysis suggests that product market regulation may have economically significant effects on employment insecurity. However, the evidence that strict product market regulations reduce employment insecurity is not terribly robust and is subject to two caveats of importance for 
drawing policy lessons. First, the concentration of any gains in employment security on workers in the most regulated industries suggests that relatively few workers benefit. Second, product market regulations this strict appear to have important efficiency costs [OECD, (1997b)]. These considerations suggest that constraints on competition in product markets do not provide a particularly cost-effective policy lever for raising employment security. This conclusion is reinforced by the finding that certain labour market policies appear to be more important determinants of employment security than is the level of product market competition. In particular, EPL has important effects on both the risk of job loss and unemployment durations, while more generous unemployment benefits and higher union density appear to enhance subjective appraisals of job security.

86. In sum, this analysis suggests that security goals deserve some attention when implementing regulatory reforms in product markets. Deregulatory initiatives -- particularly those targeted at industries where competition levels have been low -- may give rise to long-run increases in employment insecurity that policy makers may wish to address with measures that are directly targeted at improving the functioning of the labour market. This suggests a potential complementarity between product market reforms that increase competition and improvements in the assistance available to job losers to find new jobs (e.g. ALMPs providing job-search assistance or training) or policies to cushion the adverse impact of job loss on family incomes (e.g. unemployment insurance).

\subsection{Inequality}

87. As used here, "inequality" refers to earnings and income inequality, with the primary focus being on earnings inequality (i.e. the dispersion of earnings across individual workers) since that is the aspect of inequality the most closely related to the labour market. ${ }^{87}$ The vast recent literature on earnings inequality has not identified product market regulations as ranking among the principal determinants of earnings inequality [Katz and Autor (1999)]. Nonetheless, the level of product market competition might affect earnings inequality through the following channels:

- Product market regulations restricting competition are often associated with wage premia (Section III). This suggests that inter-industry differences in regulation are likely to alter interindustry relativities in average wages. It follows that restrictions on product market competition typically affect the distribution of earnings, but the effect on overall earnings inequality appears to be difficult to predict. ${ }^{88}$

- Regulatory changes in product markets that increase competitive pressures will tend to reduce the rents available for unions to capture through collective bargaining, potentially leading to declines in union power or more decentralised wage bargaining that, in turn, result in greater wage dispersion. Such a development may be less probable in countries where union membership rates are high or centralised/co-ordinated collective bargaining is well established.

- The impacts of product market regulations on the size distribution of firms or their innovation potential (see Section II) may, in turn, affect earnings inequality. In particular, increased competition may result in more rapid development and diffusion of new production technologies. Since such technologies (and R\&D, itself) are typically intensive in the use of skilled labour, this shift in relative demand will, ceteris paribus, raise the relative wage of skilled labour and increase earnings inequality.

87. Product market regulations can also affect income distribution through channels that do not involve the labour market. For example, price decreases resulting from regulatory reform in a particular industry will advantage families who are intensive consumers of its products.

88. Increased product market competition due to imports caused wage inequality to rise during recent decades in the United States [Borjas and Ramey (1995)], because wage rents were reduced most for production workers with lower levels of education. However, this may not be a general pattern. 
- The effects of product and labour market regulations on the overall level and sectoral composition of employment (see Section III) will tend to affect the distribution of employment and unemployment across groups of workers or households, potentially altering the distribution of labour incomes.

\section{Measures of inequality}

88. Table 16 describes the three inequality measures used in the analysis: Earnings inequality is measured both in terms of the overall dispersion of earnings (measure 1) and the incidence of low-paid employment (measure 2). The poverty rate among workers is also considered (measure 3 ), where poverty is defined as a sizeadjusted family income less than one-half the national median value. ${ }^{89}$ An important limitation of these measures is that none takes account of how product market regulations may affect the living standards of families with no working members, who are at an elevated risk of poverty [OECD (2001c)]. Restrictions on competition that result in lower aggregate employment (Section III) will tend to increase the number of such families. Unfortunately, it proved impossible to incorporate this aspect of inequality into the industry-based framework adopted in this study, because non-working families usually lack a meaningful industrial affiliation.

Table 16. Measures of inequality used in the analysis

\begin{tabular}{|c|c|c|c|c|}
\hline Description of variable & Source of data & $\begin{array}{l}\text { Industry } \\
\text { coverage }^{1}\end{array}$ & $\begin{array}{l}\text { Country } \\
\text { coverage }\end{array}$ & Comments on interpretation \\
\hline \multicolumn{5}{|l|}{ Measures of earnings inequality: } \\
\hline $\begin{array}{l}\text { 1. Wage inequality (ratio of } \\
\text { 80th percentile earnings to } \\
\text { 20th percentile earnings) }\end{array}$ & $\begin{array}{l}\text { European } \\
\text { Community } \\
\text { Household Panel }\end{array}$ & $5(3)$ & 10 & $\begin{array}{l}\text { Higher values for D8/D1 indicate greater intra-industry } \\
\text { earnings inequality. (The percentile values are calculated } \\
\text { separately for each industry.) }\end{array}$ \\
\hline $\begin{array}{l}\text { 2. Workers with low-paid jobs } \\
\text { (per cent of workers earning } \\
\text { less than two-thirds of national } \\
\text { median value) }\end{array}$ & $\begin{array}{l}\text { European } \\
\text { Community } \\
\text { Household Panel }\end{array}$ & $5(3)$ & 10 & $\begin{array}{l}\text { Higher values indicate a greater incidence of workers } \\
\text { earning substantially less than a typical worker in their } \\
\text { home country. This measure reflects both inter- and intra- } \\
\text { industry earnings inequality. }\end{array}$ \\
\hline \multicolumn{5}{|l|}{ Measures of the income inequality: } \\
\hline $\begin{array}{l}\text { 3. Rate of working poverty } \\
\text { (per cent of workers living in } \\
\text { families in poverty) }\end{array}$ & $\begin{array}{l}\text { European } \\
\text { Community } \\
\text { Household Panel }\end{array}$ & $5(3)$ & 10 & $\begin{array}{l}\text { Higher values indicate a greater share of workers whose } \\
\text { earnings do not raise the size-adjusted incomes of their } \\
\text { families to one-half of the national } \\
\text { median value. }\end{array}$ \\
\hline
\end{tabular}

1. Number of service industries for which both the inequality measure and the global index of product market regulation are available. The value in parentheses is the number of cases in which there is an exact match of industry definitions between the two variables. Regressions using only the exact-match industries give similar results to those also using industries where the match was approximate. (See Annex 2 for details.)

89. Since relative definitions are adopted for low pay and poverty, international differences in average earnings and income are not reflected in these inequality measures. The low pay definition is adopted from the analysis of earnings inequality and mobility in the 1996-1997 issues of the Employment Outlook and the poverty definition from the analysis of poverty dynamics in the 2001 issue of the Employment Outlook [OECD (1996b, 1997a, 2001c)]. 
89. Figure 10 displays the three inequality measures and their cross-country association with the overall index of product market regulations. ${ }^{90}$ There is considerable cross-country variation in the inequality measures with wage inequality - particularly, the incidence of low-paid employment -- tending to be lower in countries with stricter regulation. By contrast, the incidence of in-work poverty seems to increase with the regulation of product markets. ${ }^{91}$ Overall, these bivariate associations are relatively consistent with the hypothesis that greater competition in product markets might lead to greater earnings inequality. However, multivariate analysis is required to assess whether these bivariate associations reflect a causal relationship and, hence, a potential trade-off between efficiency and equity goals. Regression analysis

90. Table 17 presents regression results using 1998 values of the three measures of inequality as the dependent variable. The estimation results suggest that the bivariate associations between inequality and product market regulations shown in Figure 10 probably do not reflect important causal links between the vigour of product market competition and earnings or income inequality. No statistically significant effect of regulation is found in augmented and preferred specifications, when industry dummies are added to the model, although a negative coefficient is estimated in the basic specification when the rate of working poverty is used as dependent variable.

91. Higher union density is associated with a reduced incidence of low-paid employment and, perhaps, a decrease in overall earnings dispersion, consistent with previous research findings that unions compress the wage structure. Both higher union density and more generous unemployment insurance benefits may be associated with reductions in the share of workers whose families are poor, although the unionisation effect disappears with controls for industry effects. The estimated effect of higher unemployment benefits -- which serves here as a proxy for the overall generosity of the welfare state - is quite strong, with a one standard deviation increase in the replacement rate implying a 0.45 standard deviation decrease in the incidence of working poverty, approximately twice as strong as the larger of the two estimates of the impact of union density on working poverty.

\section{Conclusions for inequality}

92. This analysis provides little support for the hypothesis that product market regulations have a long-run impact on inequality in the labour market. Deregulation in product markets may nonetheless occasion significant economic losses in the transition to a more competitive equilibrium, for example, those experienced by workers whose wages had included a premium that reflected monopoly rents, although that possibility was not analysed in this paper. However, this appears to be a transitional concern that has few, if any, implications for choosing the product market regulations best suited to generate broadly based prosperity. By contrast, generous public income transfer programmes and a high degree of unionisation appear to have equalising effects on certain aspects of earnings and income in the long run.

90. A second measure of earnings dispersion is also shown in Figure 10, namely the ratio of earnings at the $90^{\text {th }}$ percentile to earnings at the $10^{\text {th }}$ percentile. The 90-10 ratio is included because it is available for a wider range of OECD countries and is a more common measure of earnings dispersion than the $80-20$ ratio. The small sample sizes available in the European Community Household Panel meant that the 90-10 ratio could not be reliably calculated at the industry level, as is required for the regression analysis.

91. A greater prevalence of low-paid jobs need not translate into a higher poverty rate since workers with low earnings may be members of families with other sources of income (e.g. earnings from other workers or public income transfers). 
Figure 9. Overall product market regulation and insecurity, 1998
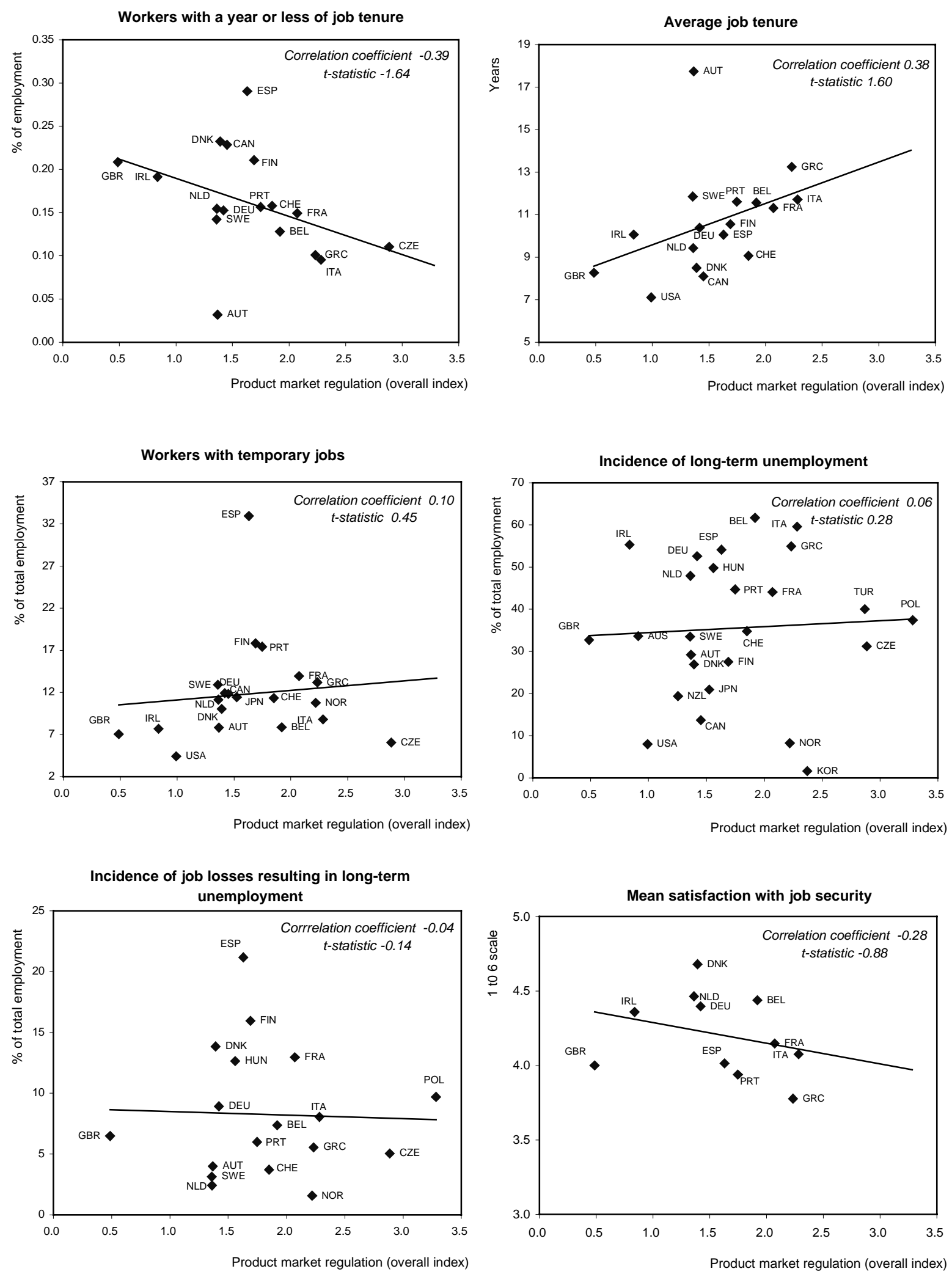
Table 17. Policies, institutions and inequality ${ }^{1}$

Results for panel regressions of service industries

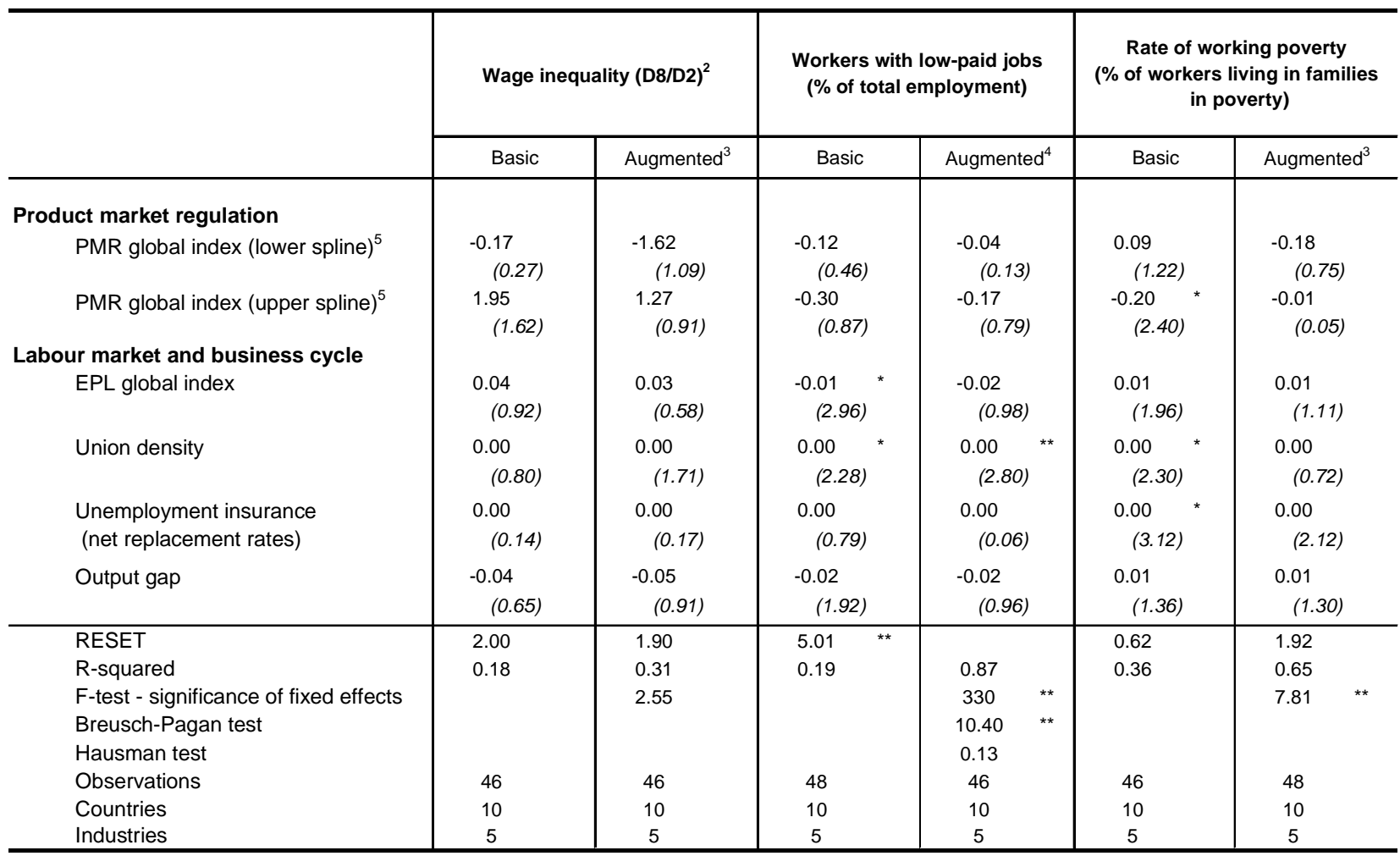

1. See Table 16 for the definitions of the inequality measures (i.e. the dependent variables).

2. D8/D2 refers to the ratio of wage rates at the breakpoint between the eighth and the ninth deciles and the breakpoint between the second and the third deciles.

3. Basic model augmented to include industry fixed effects. It is estimated by OLS, the standard errors being adjusted for clustering.

4. Basic model augmented to include industry fixed effects and country random effects. It is estimated by GLS.

5. The effects of the global index for PMR are modeled as linear splines with a single kink point.

Note: ${ }^{*},{ }^{* *}$ denote significance at the $5 \%$ and $1 \%$ level, respectively. All equations include a constant. T-statistics in parentheses.

Samples are adjusted for outliers based on the Welsch distance cut-off (Chatterjee and Hadi, 1988).

Basic model is estimated by OLS, the standard errors being adjusted for clustering. 


\section{REFERENCES}

ACEMOGLU, D. and R. SHIMER (2000) “Wage and Technology Dispersion”, Review of Economic Studies, 67, 585-607.

ACEMOGLU, D. and S. PISCHKE (1998), "Why Do Firms Train? Theory and Evidence", Quarterly Journal of Economics, Vol. 113, pp. 79-119.

ACEMOGLU, D. and S. PISCHKE (1999a), “The Structure of Wages and Investment in General Training", Journal of Political Economy, Vol. 107, pp. 539-572.

ACEMOGLU, D. and S. PISCHKE (1999b), "Beyond Becker: Training in Imperfect Labor Markets", Economic Journal, Vol. 109, pp. F112-142.

ACEMOGLU, D. and S. PISCHKE (1999c), "Minimum Wages and On-the-Job Training", NBER Working Paper No. 7184.

ACEMOGLU, D. (2000), "Productivity Gains from Unemployment Insurance", European Economic Review, Vol. 44, pp. 1195-1224.

ACEMOGLU, D., P. AGHION and G. VIOLANTE (2001), "Deunionisation, Technical Change and Inequality", CEPR Discussion Paper No. 2764.

AGELL, J. (1999), "On the Benefits from Rigid Labour Markets: Norms, Market Failures, and Social Insurance," The Economic Journal, 109, pp. F143-F164, February.

AGHION, P. and P. HOWITT (1998), Endogenous Growth Theory, Cambridge: Mass.: The MIT Press.

AGHION, P., C. HARRIS and J. VICKERS (1997), "Competition and Growth with Step-by-Step Innovation: An Example", European Economic Review, Vol. 41, pp. 771-782.

AGHION, P., C. HARRIS, P. HOWITT and J. VICKERS (2001a), "Competition, Imitation and Growth with Step-by-Step Innovation", Review of Economic Studies, forthcoming.

AGHION, P., N. BLOOM, R. BLUNDELL, R. GRIFFITH and P. HOWITT (2001b), "Empirical Estimates of Product Market Competition and Innovation", University College London, Mimeo.

AHN, S. and P. HEMMINGS (2000), "Policy Influences on Economic Growth in OECD Countries: An Evaluation of the Evidence", OECD Economics Department Working Paper, No. 246.

ALBAEK, K., M. VAN AUDENRODE and M. BROWING (1998), "Employment protection and the consequences for displaced workers: a comparison of Belgium and Denmark, Mimeo, unpublished.

AMABLE, B. and D. GATTI (2001), “The Impact of Product Market Competition on Employment and Wages", IZA Discussion Paper, No. 276, March. 
AUDRETSCH, D. and R. THURIK (2001), "Linking Entrepreneurship to Growth", STI Working Papers 2001/2, OECD, Paris.

BASSANINI, A, and ERNST, E (2001), " Labour Market Institutions, Product Market Regulation, and Innovation: Cross-country Evidence", OECD Economics Department Working Papers, No.

BASSANINI, A., S. SCARPETTA and P. HEMMINGS (2001), "Economic Growth: the Role of Policies and Institutions. Panel Data Evidence from OECD Countries" OECD Economics Department Working Paper, No. 283.

BERTOLA, G. (1992), "Labour Turnover Costs and Average Labour Demand", Journal of Labor Economics, No. 4.

BERTOLA, G. (1999), “A pure theory of job security and labor income risk”, Mimeo, European University Institute.

BLANCHARD, O. and F. GIAVAZZI (2001), "Macroeconomic Effects of Regulation and Deregulation in Goods and Labor Markets", MIT Department of Economics Working Paper, No. 01-02.

BLAU, D.M. (1987), “A Time-Series Analysis of Self-Employment in the United States”, Journal of Political Economy, Vol. 95, pp. 445-467.

BLAU, F. and L. KAHN (1999), "Institutions and Laws in the Labor Market", Chapter 25 in Ashenfelter, O. and Card, D. (eds) Handbook of Labour Economics, Vol. 3a, Amsterdam: North-Holland.

BLAU, F. and L. KAHN (1996), "International Differences in Male Wage Inequality: Institutions vs. Market Forces”, Journal of Political Economy, Vol. 104, pp. 791-837.

BLINDER, A. and A. KRUEGER (1996), "Labor Turnover in the USA and Japan: A Tale of Two Countries", Pacific Economic Review, Vol. 1, pp. 27-57.

BLUNDELL, R., R. GRIFFITH and J. VAN REENEN (1995), "Dynamic Count Data Models of Technological Innovation", Economic Journal, Vol. 105, pp. 333-344.

BLUNDELL, R., R. GRIFFITH and J. VAN REENEN (1999), "Market Share, Market Value and Innovation in a Panel of British Manufacturing Firms", Review of Economic Studies, Vol. 66, pp. 529-554.

BOERI, T., G. NICOLETTI and S. SCARPETTA (2000), "Regulation and Labour Market Performance", CEPR Discussion Paper Series, No. 2420.

BOONE, J. (2000a), “Competition”, Center Discussion Paper No.2000-104, Tilburg University, Netherlands, October.

BOONE, J. (2000b), "Competitive Pressure: The Effects on Investments in Product and Process Innovation", RAND Journal of Economics, Vol. 31, No. 3, pp. 549-569.

BORJAS, G. J. and V. A. RAMEY (1995), "Foreign Competition, Market Power, and Wage Inequality", Quarterly Journal of Economics, Vol. 110 (4), pp. 1075-1110.

BROWN, C. and J. MEDOFF (1989), “The Employer Size Wage Effect”, Journal of Political Economy, Vol. 97, pp. 1027-1059.

CALMFORS, L. and J. DRIFFILL (1988), "Bargaining Structure, Corporatism and Macroeconomic Performance", Economic Policy, Vol. 6, 14-61. 
CAMERON, G. (1998), "Innovation and Growth: A Survey of the Empirical Evidence", Mimeo, Nuffield College, University of Oxford.

CAMERON, G. (2000), "R\&D and Growth at the Industry Level", Nuffield College Discussion Paper No. 2000-W4.

CARD, D. (1996), "The Effect of Unions on the Structure of Wages: A Longitudinal Analysis", Econometrica, Vol. 64, No. 4, 957-979.

CARD, D. (1998), "Deregulation and Labor Earnings in the Airline Industry", in Regulatory Reforms and Labor Markets, edited by J. Peoples, Norwell, Mass.: Kluwert Academic Publishers.

CAROLI, E., N. GREENAN and D. GUELLEC (2001), "Organizational Change and Skill Accumulation", Industrial and Corporate Change, Vol. 10, pp. 481-506.

CENTENO, M. (2000), "Is self-employment a response to labor market rigidity? Panel evidence and the Portuguese case", Mimeo, Banco de Portugal, November

CHATTERJEE, S. and A. HADI (1988) Sensitivity Analysis in Linear Regression, New York: Wiley.

COHEN, W. and D. LEVINTHAL (1989), "Innovation and Learning: The Two Faces of R\&D”, Economic Journal, Vol. 99, pp. 569-596.

DASGUPTA, P. and J. STIGLITZ (1980), "Industrial Structure and the Nature of Innovative Activity", Economic Journal, Vol. 90, pp. 226-293.

DAVIDSON, R. and J. MACKINNON (1981), "Several Tests of Model Specification in the Presence of Alternative Hypotheses", Econometrica, Vol. 49, pp. 781-793.

DAVIS, S. J. and J. HALTIWANGER (1991), "Wage Dispersion Between and Within US Manufacturing Plants", Brookings Papers on Economic Activity: Microeconomics, pp. 115-180.

DAVIS, S. J. and J. HALTIWANGER (1996), "Employer Size and the Wage Structure in US Manufacturing Plants", Annales d'Économie et Statistique, Vol. 41-42, pp. 323-367.

DAVIS, S. J. and M. HENREKSON (1999), "Explaining National Differences in the Size and Industry Distribution of Employment", Small Business Economics, Vol. 12, pp. 59-83.

DAVIS, S. J. (1992), "Cross-Country Patterns of Change in Relative Wages", NBER Macroeconomic Annual, Vol. 7, pp. 239-292.

EICHENGREEN, B. and T. IVERSEN (1999), "Institutions and Economic Performance: Evidence from the Labour Market”, Oxford Review of Economic Policy, Vol. 15, pp. 121-138.

ELMESKOV, J., J. MARTIN and S. SCARPETTA (1998), "Key Lessons for Labour Market Reforms:

Evidence from OECD Countries' Experiences”, Swedish Economic Policy Review, Vol. 5, pp. 205-252.

FARBER, H.S. (2001), "Job loss in the Unites States, 1981-1999”, Princeton University, Industrial Relations Section, Working Paper No. 453, June.

FLANAGAN, R. (1999), "Macroeconomic Performance and Collective Bargaining: An International Perspective", Journal of Economic Literature, 37(3), pp. 1150-75. 
GASTON, N. and D. TREFLER (1994), "Protection, Trade and Wages: Evidence from U.S. Manufacturing", Industrial and Labour Relations Review, Vol. 47, 574-593.

GASTON, N. and D. TREFLER (1995), "Union Wage Sensitivity to Trade and Protection: Theory and Evidence", Journal of International Economics, Vol. 39, 1-25.

GEROSKI, P.A. (1990), "Innovation, Technological Opportunity, and Market Structure", Oxford Economic Papers, Vol. 42, pp. 586-602.

GERSBACH, H. and A. SCHNIEWIND (1999), "Imperfect Competition, General Equilibrium and Unemployment”, CESifo Working Paper No. 224, December.

GITTLEMAN, M. and E.N. WOLFF (1993), "International Comparisons of Inter-Industry Wage Differentials", Review of Income and Wealth, Series 39, No. 3, pp. 295-312.

GONENC, R., M. MAHER and G. NICOLETTI (2000), "The implementation and the effects of regulatory reform: past experience and current issues", OECD Economics Department Working Paper, No. 251, Paris.

GOTTSCHALK, P. and T. SMEEDING (1997), "Cross National Comparisons of Earnings and Income Inequality”, Journal of Economic Literature, Vol. 35, pp. 633-687.

GRILICHES, Z. (1990), "Patent Statistics as Economic Indicators: A Survey", Journal of Economic Literature, Vol. 28, pp. 1661-1797.

GUELLEC, D. and B. VAN POTTELSBERGHE (2001), "R\&D and productivity growth: panel data analysis of 16 OECD countries", OECD STI Working Papers, No. 2001/3.

JEAN, S. and G. NICOLETTI (2001), "Product market regulation and wage premia in Europe and NorthAmerica: An empirical investigation", OECD Economics Department Working Paper, forthcoming, Paris.

HAISKEN-DENEW, J.P. and C.M. SCHMIDT (1999), "Industry Wage Differentials Revisited: A Longitudinal Comparison of Germany and USA (1984-1996)", IZA Discussion Paper, No. 98.

HASKEL, J. and A. SANCHIS (1995), "Privatisation and X-inefficiency: A Bargaining Approach", The Journal of Industrial Economics, Vol. 43, No. 3, September.

HATZICHRONOGLOU, T. (1997), "Revision of the High-technology Sector and Product Classification", STI Working Paper No. 1997/2, OECD, Paris.

HENDRICKS, W. (1977), "Regulation and Labor Earnings”, The Bell Journal of Economics, Vol. 8, pp. 483496.

HENDRICKS, W. (1994), "Deregulation and Labor Earnings", Journal of Labor Research, Vol. XV, No. 3, pp. 207-234, Summer.

HENREKSON, M. and D. JOHANSSON (1999), "Institutional Effects on the Evolution of the Size Distribution of Firms", Small Business Economics, Vol. 12, pp. 11-23.

HICKS, J. (1935), “Annual survey of economic theory: the theory of monopoly", Econometrica, Vol. 3, pp. 120. 
HOBJIN, B. and B. JOVANOVIC (2001), "The Information Technology Revolution and the Stock Market: Evidence", American Economic Review, forthcoming.

KAHN, L. (1998), "Collective Bargaining and the Inter-industry Wage Structure: International Evidence", Economica, Vol. 65, pp. 507-534.

KATZ, L.F. and D.H. AUTOR (1999), "Changes in the Wage Structure and Earnings Inequality," chapter 26 in Handbook of Labour Economics, Vol. 3a, Ashenfelter and Card (editors), North Holland.

KATZ, L.F. and L.H. SUMMERS (1989), "Industry Rents: Evidence and Implications”, Brookings Papers on Economic Activity: Microeconomics, 209-275, Washington D.C.

KING, M. and D. FULLERTON (1984), The Taxation of Income from Capital, The University of Chicago Press.

KLETZER, L. (1992), "Industry Wage Differentials and Wait Unemployment", Industrial Relations, Vol. 31, No. 2, pp. 250-269.

KLETZER, L.G. (1998), “Job Displacement”, The Journal of Economic Perspectives, Vol. 12 (1), pp. 115-136.

KRUEGER, A.B. and J.S. PISCHKE (1997), "Observations and Conjectures on the U.S. Employment Miracle", NBER Working Paper, No. 6146.

KRUEGER, A.B. and L.H. SUMMERS (1988), "Efficiency Wage and Inter Industry Wage Structure", Econometrica, 56, pp. 259-293.

LAYARD, R. and S.J. NICKELL (1990), "Is unemployment lower if unions bargain over employment?" Quarterly Journal of Economics, Vol. 105 (3), pp. 773-787.

LAYARD, R., S.J. NICKELL and R. JACKMAN (1991), Unemployment: Macroeconomic Performance and the Labour Market, (Oxford: Oxford University Press).

LEVIN, R. and P. REISS (1984), “Tests of a Schumpeterian Model of R\&D and Market Structure”, in Z. Griliches (ed.), R\&D, Patents, and Productivity, Chicago: The University of Chicago Press.

LYNCH, L. (1994) (ed.), Training and the Private Sector: International Comparisons, Chicago: University of Chicago Press for the NBER.

MACHIN, S. and A. MANNING (1999), "The Causes and Consequences of Longterm Unemployment in Europe", Chapter 47 in Ashenfelter, O. and Card, D. (eds) Handbook of Labour Economics, Vol. 3c, Amsterdam: North-Holland.

McCUE, K. (1996), "Promotions and Wage Growth”, Journal of Labor Economics, Vol. 14, pp. 175-209.

MORTENSEN, D.T. and C.A. PISSARIDES (1999a), "New Developments in Models of Search in the Labor Market," Chapter 39 in Handbook of Labour Economics, Vol. 3b, Ashenfelter and Card (editors), North Holland.

MORTENSEN, D.T. and C.A. PISSARIDES (1999b), "Job Reallocation, Employment Fluctuations and Unemployment," Chapter 18 in Handbook of Macroeconomics, Vol. 1b, Taylor and Woodford (editors), North Holland.

MOULTON, B.R. (1986), "Random group effects and the precision of regression estimates", Journal of Econometrics, 32, pp. 385-397. 
NELSON, R. and S. WINTER (1982) An Evolutionary Theory of Economic Change, Cambridge, Mass.: The Belknap Press of Harvard University Press.

NICKELL, S. and R. LAYARD (1999), "Labour Market Institutions and Economic Performance", in O. Ashenfelter and D. Card (eds), Handbook of Labor Economics, Vol. 3, Amsterdam: North-Holland Press.

NICKELL, S. (1996), “Competition and Corporate Performance”, Journal of Political Economy, Vol. 104, pp. 724-746.

NICKELL, S. (1999), "Product Markets and Labour Markets", Labour Economics, Vol. 6, pp. 1-20.

NICKELL, S., J. VAINIOMAKI and S. WADHWANI (1994), “Wages and Product Market Power”, Economica, No. 61, pp. 457-473.

NICOLETTI, G. and S. SCARPETTA (2001), "Interactions Between Product and Labour Market Regulations: Do They Affect Employment? Evidence from OECD Countries", OECD Economics Department Working Paper, forthcoming, Paris.

NICOLETTI, G., R. C. G. HAFFNER, S. NICKELL, S. SCARPETTA and G. ZOEGA (2001), "European Integration, Liberalisation and Labour Market Performance", in G. Bertola, T. Boeri and G. Nicoletti (eds), Welfare and Employment in a United Europe, Cambridge, Mass.: The MIT Press.

NICOLETTI, G., S. SCARPETTA and O. BOYLAUD (1999), "Summary Indicators of Product Market Regulation with an Extension to Employment Protection Legislation", OECD Economics Department Working Papers, No. 226.

OECD (1993), Education at a Glance, Paris, June.

OECD (1994a), “The OECD Jobs Study: Facts, Analysis, and Strategies”, Paris.

OECD (1994b), “The OECD Jobs Study, Evidence and Explorations, Part II”, Paris.

OECD (1995), "Competition, Regulation and Performance", Economics Department, Working Party No. 1 of the Economic Policy Committee, ECO/CPE/WP1(95)6.

OECD (1996a), "Competition, wages and productivity", Economics Department, Working Party No. 1 of the Economic Policy Committee, ECO/CPE/WP1(96)1.

OECD (1996b), Employment Outlook, Paris, June.

OECD (1997a), Employment Outlook, Paris, June.

OECD (1997b), The OECD Report on Regulatory Reform, Paris.

OECD (1998a), Fostering Entrepreneurship, Paris.

OECD (1998b), Employment Outlook, Paris, June.

OECD (1999a), "Cross-country Patterns of Product Market Regulation”, OECD Economic Outlook n. 66, Paris.

OECD (1999b), “Implementing the OECD Jobs Strategy: Assessing Performance and Policy”, Paris.

OECD (1999c), Employment Outlook, Paris, June. 
OECD (2000a), "Recent growth trends in OECD countries", OECD Economic Outlook n. 67, Paris.

OECD (2000b), "Links between policy and growth: cross-country evidence", OECD Economic Outlook No. 68, Paris.

OECD (2000c), Education at a Glance, Paris, June.

OECD (2000d), "A New Economy? The Changing Role of Innovation and Information Technology in Growth", Paris.

OECD (2001a), OECD Economic Studies n.32, Special issue on regulatory reform, Paris.

OECD (2001b), "Productivity and Firm Dynamics: Evidence from Micro-Data", OECD Economic Outlook No. 69, Paris.

OECD (2001c), Employment Outlook, Paris, June.

OI, W. and T.L. IDSON (1999), "Firm Size and Wages", in O. Ashenfelter and D. Card (eds), Handbook of Labor Economics, Vol. 3, Amsterdam: North-Holland Press.

OLIVEIRA-MARTINS, J. (1993), “Market Structure, International Trade and Relative Wages", OECD Economics Department Working Paper, No. 134.

PAVITT, K. (1984), "Sectoral Patterns of Technical Change: Towards a Taxonomy and a Theory", Research Policy, Vol. 13, pp. 343-373.

PAVITT, K. (1995), "Key Characteristics of Large Innovating Firms", in M. Dodgson and R. Rothwell (eds), The Handbook of Industrial Innovation, Elgar.

PEOPLES, J. (1998), "Deregulation and the Labor Market", Journal of Economic Perspectives, Vol. 12, No. 3, pp. 111-130.

PHELPS, E.S. (1994), "Structural Slumps: The Modern Equilibrium Theory of Unemployment, Interest and Assets", Cambridge, Mass: Harvard University Press.

PISSARIDES, C. (1998), “The Impact of Employment Tax Cuts on Unemployment and Wages: The Role of Unemployment Benefits and Tax Structure", European Economic Review, Vol. 42, pp. 155-183.

PISSARIDES, C.A. (2001), “Employment Protection,” Labour Economics, 8, pp. 131-159.

PIZER, S.D. (2000), “Does International Competition Undermine Wage Differentials and Increase Inequality?", Journal of International Economics, Vol. 52, pp. 259-282.

SCHMALENSEE, R. (1989), "Inter-Industry Studies of Structure and Performance”, in Schmalensee, R. and R. Willig (eds), Handbook of Industrial Organization, Volume II, Amsterdam: North-Holland.

SCHUETZE, H.J. (2000), "Taxes, Economic Conditions and Recent Trends in Male Self-Employment: A Canada-US Comparison", Labour Economics 7(5), pp. 507-44

SOSKICE, D. (1997), "German Technology Policy, Innovation, and National Institutional Frameworks", Industry and Innovation, Vol. 4, pp. 75-96.

SPECTOR, D. (2000), "Competition and the Capital-Labor Conflict", mimeo, http://www.ecare.ulb.ac.belecare/papers/ds2301.pdf, May. 
ECO/WKP(2001)38

SUTTON, J. (1998), Technology and Market Structure, Cambridge, Mass.: The MIT Press.

TOPEL, R. and M. WARD (1992), “Job Mobility and the Careers of Young Men”, Quarterly Journal of Economics, Vol. 107, pp. 439-480.

VICKERS, J. (1995), “Entry and Competitive Selection”, Mimeo.

WATSON WYATT Worldwide (1997), Employment Terms and Conditions: Europe, Brussels: Watson Wyatt.

ZIMMERMANN, K. (1998), "German Job Mobility and Wages", in I. Ohashi and T. Tachibanaki (eds), Internal Labour Markets, Incentives and Employment, London: MacMillan. 
ECO/WKP(2001)38

\section{ANNEX 1. DATA SOURCES AND METHODOLOGY}

\section{Structure and performance of product and labour markets.}

\subsection{Indicators of innovative activity: definitions, sources and limitations}

93. The analysis discussed in this paper is based on several indicators of innovative activity: aggregate and industry-level R\&D intensity, aggregate patenting performance and aggregate intensity of information technology (IT):

- Aggregate R\&D intensity is defined as the ratio of Business Expenditure in Research and Development (BERD) to GDP and the data are drawn from the OECD MSTI database. Industry-level $R \& D$ intensity is defined as the ratio of BERD to output. Data on industrylevel BERD are drawn from the OECD ANBERD database, except in the case of Austria, for which the OECD R\&D database was used. Data on industry output are the result of the harmonisation of different sources (OECD STAN Database - edition 2000, OECD Annual National Accounts Database, OECD Industrial Structure Statistics - ISIS). The data covers all manufacturing industries at 2-digit ISIC Rev.3 classification. ${ }^{92}$ Data on the ratio of government-financed BERD to total BERD are from the OECD R\&D database. All R\&D variables have been averaged across 1993-1997, excluding years where missing observations amounted to most of the industries.

- Patenting refers to consolidated patents granted by the USPTO, the EPO and the JPO, by priority year 1993 and country of origin. The data are drawn from the OECD Patent database (see OECD, 2001a).

- IT intensity is defined as the ratio of expenditure in IT to GDP. The data are drawn from OECD (2000a) and refer to an average over the 1995-1997 period.

94. Each of these indicators of innovative activity suffer from limitations that should be borne in mind in interpreting empirical results (for a general discussion, see Griliches, 1990):

- R\&D intensity is an indicator of input in the innovative process rather than output. Consequently improvements in the efficiency of the innovation process (greater output with less input) can be mistakenly interpreted as a reduction of the innovative effort (this is particularly important when the competitive selection effect of regulatory reform is at work). Furthermore, R\&D intensity might be a biased indicator even of the R\&D input due to different accounting practices between large and small firms. Reported data tend to

92. "Manufacturing n.e.c." (ISIC 36 and 37), being a residual sector, has been excluded, while "Food, beverages and tobacco" (ISIC 15 and 16) and "Textiles" (ISIC 17, 18 and 19) have been aggregated due to data limitations. 
overestimate $R \& D$ intensity of large firms relative to small firms and new entrants. Moreover, R\&D intensity conveys only information about formal innovation expenditure. In many industries, especially service ones, informal innovation is a sizeable component of overall innovation activity. Finally, information about R\&D expenditure is generally not available or not reliable in non-manufacturing industries.

- Patenting is an indicator of the output of innovative activity. However, cross-country comparable data at the industry level are not currently available. Moreover, patenting closely depends on industrial structure (in certain industries, such as machine tools, it can be effectively replaced by industrial secrecy) and, therefore, is not strictly comparable across industries (see e.g.. Scherer, 1983; Acs and Audretsch, 1989; Griliches, 1990; and Audretsch, 1995). Finally, the available data are likely to reflect mainly the behaviour of incumbents in industries and countries where competitive struggle is tight. Therefore, these data may also suffer from statistical bias.

- IT intensity may be considered as an indicator of adoption of new technologies and organisational change to the extent that new technologies are more information based and new work practices rely more strongly on the management of information flows (see e.g. Black and Lynch, 2000; Arnal and Torres, 2001; Bresnahan, 2001; Bresnahan et al., 2001; Caroli and Van Reenen, 2001). There are several problems with this indicator too. First, adoption and innovation are different components of technological change. Second, available data lack the industry dimension. Third, it generally includes both investment and consumption expenditure. Fourth, given the complementarity between adoption and information technologies, it tends to reflect more the stock of past adoptions than current innovative activity.

\subsection{Size distribution of firms}

95. Data on firm size are from the OECD SME Database. Common dimensional classes have been reconstructed on the basis of available raw information. Furthermore, firms with less than 10 employees have been excluded due to concerns on the quality and comparability of data regarding this class of firms. Consequently, only three classes are available on a comparable basis (firms with more than 9 employees, firms with more than 9 but less than 50 employees and firms with more than 49 employees). On the basis of available data concerning total employment, dependent employment, sales and number of firms, three types of measures have been constructed for each class:

- Average employment size of firms defined as the ratio of total employment in the class to number of firms in the class.

- Share of total output defined as the ratio of output produced by firms in the class to output produced by all firms with more than 9 employees.

- Share of dependent employment defined as the ratio of dependent employment of firms in the class to dependent employment of all firms with more than 9 employees.

- Share of total employment defined as the ratio of total employment of firms in the class to total employment of all firms with more than 9 employees. In the case of Canada 
dependent employment is used instead of total employment, due to lack of data for total employment. $^{93}$

96. In this paper, the share of total employment of firms with more than 49 employees has been used more intensively due to the larger coverage of countries (this variable was re-named share of large firms for brevity throughout the paper). All regression results are however qualitatively robust to changes in the size measure. Experimentation with different regression specifications showed that, in particular, the employment share of large firms might be a valid proxy for the average employment size of firms with more than 9 employees.

97. The country-independent (average) firm size variable used to characterise industries in some regressions (e.g. wage premia) was calculated for each industry as the estimated coefficient of the corresponding industry dummy in a regression where the dependent variable is average firm size, for each industry in each country, and independent variables only include industry and country dummies. This regression was run using all available relevant data, that is 413 observations covering 17 countries and 30 industries (see details in Table 2.1).

\subsection{Wages and skills}

98. Wages and skills data are from the OECD DEELSA database on employment in services (OECD, 2000b). The primary source of the data is the European Structure of Earnings Survey (Eurostat) for EU countries, OECD calculations on the microdata file of the outgoing rotation group of the Current Population Survey for the US, and Structure of Earnings Surveys or Labour Force Surveys for the other countries. The data concerns 1994 for France, 1996 for Sweden, 1995 for other EU countries, and 1998 for non EU countries. The two-digit (ISIC Rev. 3) industry breakdown includes 21 manufacturing industries and 20 non-manufacturing industries. The breakdown within the manufacturing sector is available only for the US and for a subset of EU countries.

99. For each industry, a breakdown in terms of age, gender, education and occupation was available. The four age groups are: 15-24 years, 25-34 years, 35-54 years, 55 years and over. Education is broken down in the following four categories: less than upper secondary, upper secondary, non-university tertiary, university. The 9 occupation categories correspond to the ISCO-88 one-digit classification, excluding "armed forces". Only full-time workers were considered and only those categories for which earning data is available are represented. Many possible crossings of the various identifiers are thus absent, mainly because the insufficient number of persons concerned prevents reliable estimate for average earnings.

100. The country-independent variable concerning average skills by industry (Table A2.1) was calculated as the estimated coefficient on the corresponding industry dummy in a regression where the dependent variable is the log-share of skilled workers (defined as legislators, senior officials, professionals, technicians and associate professionals) in the workforce, and independent variables only include industry and country dummies. This regression was run using all available relevant data, that is 482 observations covering 16 countries and 43 industries. The average share of unskilled workers (used in interaction with average union density in manufacturing, for each country) is built following the same principle, the unskilled being defined as the rest of the workforce; therefore, the value obtained is the opposite of the value for the average skills variable.

93. Experimentation on countries where both total and dependent employment are available showed that regressing total employment shares on dependent employment shares leads to a unitary coefficient and a non-significant constant. Thus, no bias seems to have been introduced by this approximation. 
Table A2.1 Country independent variables used in panel regressions ${ }^{1}$

Average sector characteristics

(per cent)

\begin{tabular}{|c|c|c|c|}
\hline & Entry rate ${ }^{2}$ & $\begin{array}{l}\text { Share of skilled } \\
\text { workers in sector } \\
\text { employment }\end{array}$ & $\begin{array}{l}\text { Share of firms } \\
\text { with more than } \\
50 \text { employees }^{4}\end{array}$ \\
\hline Sample & $\begin{array}{c}9 \text { OECD } \\
\text { countries } \\
1978-1998\end{array}$ & $\begin{array}{c}16 \text { OECD } \\
\text { countries from } \\
1994 \text { to } 1998^{3}\end{array}$ & $\begin{array}{c}17 \text { OECD } \\
\text { countries } \\
\text { average 1993-1997 }\end{array}$ \\
\hline Total manufacturing & 9.6 & 20.1 & 79.5 \\
\hline Food products and beverages & 8.2 & 12.2 & 81.1 \\
\hline Tobacco & 8.2 & 16.9 & 98.9 \\
\hline Textiles & 10.6 & 9.5 & 76.6 \\
\hline Wearing apparel, dyeing of fur & 10.6 & 5.7 & 66.0 \\
\hline Dressing of leather, luggage & 10.6 & 4.1 & 69.3 \\
\hline Wood, except furniture & 9.3 & 7.6 & 56.8 \\
\hline Pulp, paper and paper products & 9.7 & 11.4 & 87.6 \\
\hline Publishing, printing & 9.7 & 28.6 & 70.8 \\
\hline Coke, petroleum products & 9.2 & 38.3 & 88.6 \\
\hline Chemicals & 8.8 & 33.4 & 93.0 \\
\hline Rubber and plastics products & 9.0 & 13.7 & 75.7 \\
\hline Other non-metallic mineral products & 8.7 & 12.8 & 76.0 \\
\hline Basic metals & 8.6 & 13.9 & 94.2 \\
\hline Metal products, except machinery and eq. & 9.0 & 11.2 & 61.8 \\
\hline Machinery and equipment n.e.c. & 9.0 & 18.8 & 79.2 \\
\hline Office machinery, computers & 13.3 & 53.2 & 83.5 \\
\hline Electrical machinery n.e.c. & 9.5 & 21.3 & 84.9 \\
\hline Radio, television and communication eq. & 11.4 & 35.3 & 88.7 \\
\hline Medical and optical instruments & 9.5 & 32.5 & 79.5 \\
\hline Motor vehicles & 8.1 & 14.1 & 93.4 \\
\hline Other transport equipment & 10.0 & 26.7 & 93.1 \\
\hline \multicolumn{4}{|l|}{ Services } \\
\hline Electricity, Gas, water & 7.9 & 24.7 & 97.5 \\
\hline Electricity, Gas & 7.9 & 32.3 & 94.9 \\
\hline Water & 7.9 & 27.3 & 88.1 \\
\hline Construction & 11.4 & 12.8 & 55.6 \\
\hline Sale and repair of motor vehicles & 10.9 & 14.4 & 47.7 \\
\hline Wholesale trade & 10.9 & 30.1 & 59.7 \\
\hline Retail trade & 10.9 & 16.5 & 69.8 \\
\hline Hotels and restaurants & 14.5 & 12.2 & 52.9 \\
\hline Transport & 11.3 & 19.6 & 77.5 \\
\hline Land transport & 11.3 & 6.2 & 73.5 \\
\hline Water transport & 11.3 & 28.9 & 83.0 \\
\hline Air transport & 11.3 & 26.9 & 89.8 \\
\hline Auxiliary transport activities & 11.3 & 20.8 & 77.1 \\
\hline Post and telecommunications & 17.3 & 30.1 & 94.7 \\
\hline Financial intermediation & 8.7 & 40.9 & 97.9 \\
\hline Insurance and pension funding & 9.1 & 46.4 & 99.1 \\
\hline Auxiliary financial activities & 14.6 & 41.6 & 59.5 \\
\hline Real estate activities & 12.5 & 27.2 & 51.8 \\
\hline Renting of manchinery and eq. & 13.7 & 17.0 & 60.7 \\
\hline Computer and related activities & 19.7 & 72.1 & 68.5 \\
\hline Research and development & 17.1 & 71.3 & 77.2 \\
\hline Other business activities & 14.6 & 38.8 & 68.8 \\
\hline
\end{tabular}

1. See text for more details.

2. Entry rates for industry branches in which data were missing were assumed to be identical to the entry rates for the aggregates.

3. 1994 for France, 1996 for Sweden, 1995 for other EU countries and 1998 for non-EU countries.

4. In total employment of firms with more than 10 employees.

Source: Jean and Nicoletti (2001). 


\subsection{Trade, entry, and macroeconomic variables}

Trade

101. Import penetration is defined as the ratio of total imports to apparent demand. Export intensity is defined as the ratio of total exports to total output. Data on imports and exports are from OECD Foreign Trade Statistics. Data on output are the result of the harmonisation of different sources (OECD STAN Database - edition 2000, OECD Annual National Accounts Database, OECD Industrial Structure Statistics-ISIS).

\section{Firm entry}

102. The entry rate is defined as the number of new firms divided by total firms in an industry in a given year. Entry rates by industry, country and year are based on the firm-level data covering 10 countries estimated in OECD (2001a). The country-independent (average) industry entry rates described in Table A2.1 are calculated for each industry as the estimated coefficient of the corresponding industry dummy in a regression where the dependent variable is the entry rate, for each industry in each country, and independent variables only include industry and country dummies. This regression was run using all available relevant data, that is 2752 observations covering 9 countries and 37 industries over the 19781998 period.

\section{Macroeconomic Variables}

103. All macroeconomic variables used in this paper are from the OECD Analytical Database (ADB).

\subsection{Insecurity}

104. The analysis used six indicators of insecurity: workers with a year or less of job tenure, average job tenure, workers with temporary jobs, incidence of long-term unemployment, incidence of job losses resulting in long-term unemployment and mean satisfaction of workers with job security on their current jobs.

- Workers with a year or less of job tenure, average job tenure and workers with temporary jobs serve as proxy indicators of the probability of job loss. Higher values of workers with a year or less of job tenure indicate greater worker turnover, which is used as a proxy for an increased probability of job loss. In turn, higher values of average job tenure indicate greater job stability, which is used as a proxy for a decreased probability of job loss. Finally, higher values of workers with temporary jobs are used as a proxy for a greater share of workers facing imminent job loss. Both workers with a year or less of job tenure and workers with temporary jobs are defined as a percentage of total employment while average job tenure is defined in years. The measure of workers with temporary jobs takes into account workers with fixed-term or other temporary contracts. Data on these three measures are drawn from the OECD DEELSA database on employment in services (OECD, 2000b, 2001b). The underlying sources of these data are various labour force surveys, as tabulated by Eurostat and national statistical authorities. The data, which refer to 1998, cover nine service sectors 
with a level of detail close to the 2-digit ISIC Rev.3 classification ${ }^{94}$ and manufacturing as an aggregated sector.

- Incidence of long-term unemployment serves as a proxy for the magnitude of earnings losses following job loss. It is defined as the ratio of: i) persons formerly employed in a particular industry, who have been unemployed for a year or longer, to ii) all unemployed persons formerly employed in that industry. Higher values of incidence of long-term unemployment indicate that earnings losses following job loss are greater. Data on this measure are drawn from the European Labour Force Survey (ELFS), as tabulated by Eurostat for 1998. The data cover all manufacturing and service industries at 2-digit ISIC Rev.3 classification level.

- Incidence of job losses resulting in long-term unemployment serves as a proxy for the expected cost of job loss, i.e. the combined effect of the probability and cost of job loss. It is defined as the ratio of: i) job losers formerly employed in a particular industry, who are still unemployed one year later, to ii) total employment in that industry. This ratio reflects both the rate of involuntary job loss and the probability workers losing a job are still unemployed one year later. For the regression analysis, this incidence rate is normalised as a relative rate by industry using the country-level value as the normalisation factor. This measure was calculated using 1998 data from the European Labour Force Survey (ELFS), as tabulated by Eurostat. The data cover all manufacturing and service industries at 2-digit ISIC Rev.3 classification level.

- Mean satisfaction of workers with job security on their current jobs is a subjective appraisal by workers of job security on their current job, rated on a scale from 1 to 6 , with 6 corresponding to fully satisfied. Only wage and salary employees were considered. Data on this measure are drawn from Wave 1 of the European Community Household Panel (ECHP) Survey. Data cover six manufacturing sub-sectors and five service sub-sectors.

105. The indicators of insecurity are subject to several limitations that should be considered in interpreting the empirical results:

- An important limitation of the first three measures - workers with a year or less of job tenure, average job tenure, workers with temporary jobs - is that they do not differentiate between involuntary job loss and voluntary quits. This limitation is likely to be especially important for young workers, because workers just starting their careers typically change jobs several times before they stabilise in a given position. Another limitation of the measures related to worker turnover - particularly average job tenure - is that they reflect not only current policies and institutions - which are controlled for in the regression analysis - but also past policies. This is potentially important since some countries have recently introduced important regulatory reforms.

- Incidence of long-term unemployment and incidence of job losses resulting in long-term unemployment account neither for any differences in unemployment duration between job losers and other job searchers nor for any earnings losses once re-employed. In addition, for the second of these measures, the use of a relative incidence measure by industry means that the regression coefficients reflect only cross-industry variation within countries. Crosscountry variation in the average incidence rates appeared to be influenced by differences in questionnaire design and was therefore removed as being potentially misleading.

94. The list of industries covered is given in Table A3.1 in Annex 2. 
- Mean satisfaction of workers with job security on their current jobs is likely to be affected by international differences in how individuals perceive job security. Models including country effects may adequately control for any such cultural effects.

- Another limitation is that some of the industries for which the insecurity measures could be calculated only approximately match the industries for which the summary index of product market regulations is available. This problem affects the measures based on data from the OECD DEELSA database employment in services and the ECHP.

\subsection{Inequality}

106. The analysis used three indicators of inequality: wage inequality, workers with low-paid jobs and the rate of working poverty.

- Wage inequality is an indicator of the overall dispersion of earnings. It is defined, at the industry level, as the ratio of wage rates at the breakpoint between the eighth and the ninth deciles and the breakpoint between the second and the third deciles. Only wage and salary employees are considered. Higher values for this measure indicate greater intra-industry earnings inequality. Data on this measure are drawn from Wave 1 of the European Community Household Panel (ECHP) Survey. Data cover six manufacturing sub-sectors and five service sub-sectors.

- Workers with low-paid jobs is an indicator of the incidence of low-paid employment. It is defined as the percentage of workers earning less than two-thirds of the national median value. Higher values for this measure indicate a greater incidence of workers in a specific industry earning substantially less than a typical worker in their home country. Data sources and availability are the same as for the previous measure.

- The rate of working poverty is defined as the ratio of workers living in poverty to total employment. Higher values for this measure indicate a greater share of workers whose earnings do not raise the size-adjusted income of their families to one-half of the national median value. Data sources and availability are the same as for the two previous measures.

107. An important limitation of these inequality measures is that they do not take into account families with no working members. Since non-working families usually lack a meaningful industrial affiliation, it proved impossible to incorporate this aspect of inequality in the regression analysis. A second limitation is that some of the industries for which these inequality measures could be calculated only approximately match the industries for which the summary index of product market regulations is available.

\section{Institutions and regulation.}

\subsection{Labour Market}

\section{Union Density}

108. Sectoral union density is defined as the number of unionised employees in a given sector divided by total employment in that same sector. Data on sectoral union density are from Ebbinghaus and Visser (2000) and Booth at al. (2000) for 13 European countries (Austria, Belgium, Denmark, Finland, France, 
Germany, Italy, Netherlands, Norway, Spain, Sweden, Switzerland, and UK) and from DELSA database on employment in services (OECD, 2000b) for Canada, Ireland and the USA. The data cover mainly the period 1994-1998 with the exception of Finland where the latest available data are for 1989, USA and Canada, where only 1998 was used, and Ireland, where the data refer to 1997.

109. Available union densities suffer from many problems that greatly limit their comparability across countries and industries. First, in most countries, available union densities refer to sector aggregates wider than the two-digit level at which the analysis was performed. When no further disaggregation was available from other sources, it was assumed that union densities in 2-digit industries belonging to the same aggregate are identical. Second, with the exception of Canada, Ireland, the Netherlands, the United Kingdom, and the United States, where union density are computed from Labour Force Surveys, all other data have been provided by the unions themselves, leading to possible over-reporting. For instance unemployed or retired workers who are members of trade unions are often included in membership counts. Although continuous membership of unemployed workers is usually relatively low, in countries where union membership gives access to unemployment benefits (i.e. countries with a "Ghent" system, such as Denmark, Finland, Sweden and Belgium) actual union densities may be significantly different from what reported in the data.

\section{Economy-wide variables}

110. Table A2.2 reports the sources of the aggregate labour market policy and institutional indicators that have been used in this paper.

\subsection{Product Market}

\section{Trade barriers}

111. Data on trade barriers are from the OECD Indicators of Tariff \& Non-tariff Trade Barriers (OECD, 1997b) and refer to 1996. Original data are at the 6-digit level of the Harmonised System (HS) classification and include the number of tariff lines for each 6-digit industry (usually one). Tariffs are defined as the ad valorem tariff rates applied to the most favoured nation. Conversely, the indicator of nontariff barriers is a frequency ratio: it corresponds to the proportion of tariff lines to which non-tariff barriers apply. Indicators of tariffs and non-tariff barriers have been aggregated into indicators for 2-digit ISIC Rev. 3 industries using import-weights corresponding to 1998 trade flows across OECD countries as obtained by OECD Foreign Trade Statistics. To avoid endogeneity problems, import-weighted trade barrier indicators use the sum of all imports of OECD countries instead of national imports as weights. More specifically, the aggregation procedure that is used for country $i$ and an ISIC aggregate $I$ of 6-digit HS sectors can be formalised as follows:

$T_{I, i}=\frac{\sum_{x \in I} T_{x i} i m p_{x}}{\sum_{y \in I} i m p_{y}}$

where $T$ stands for the trade barrier indicator and imp for average OECD-wide imports. ${ }^{95}$

95. In the aggregation of tariff barrier indicators, only ad valorem tariffs are considered. To avoid tariff measures being non-representative, observations in which non-ad valorem tariffs cover more than 25 per 
ECO/WKP(2001)38

Table A2.2. Labour market policies and institutions: definitions and sources

\begin{tabular}{|c|c|c|}
\hline Indicator & Definition & Source \\
\hline Corporatism & Index of corporatism & $\begin{array}{c}\text { Elmeskov, Martin and Scarpetta (1998), } \\
\text { OECD (1997a) and OECD } \\
\text { economic surveys (various years) }\end{array}$ \\
\hline Coordination & Index of bargaining coordination & $\begin{array}{c}\text { Elmeskov, Martin and Scarpetta (1998), } \\
\text { OECD (1997a) and OECD } \\
\text { economic surveys (various years) }\end{array}$ \\
\hline Centralisation & Index of bargaining centralisation & $\begin{array}{c}\text { Elmeskov, Martin and Scarpetta (1998), } \\
\text { OECD (1997a) and OECD } \\
\text { economic surveys (various years) }\end{array}$ \\
\hline Union density & $\begin{array}{l}\text { Ratio of union members to } \\
\text { total employment }\end{array}$ & Elmeskov, Martin and Scarpetta (1998) \\
\hline EPL (individual dismissals) & Index of strictness of EPL & Nicoletti, Scarpetta and Boylaud (1999) \\
\hline EPL (collective dismissals) & $\begin{array}{l}\text { Index of strictness of regulations } \\
\text { concerning collective dismissals }\end{array}$ & OECD (1999a) and Watson Wyatt (1997) \\
\hline Coverage of collective agreements & Percentage of workers covered & $\operatorname{OECD}(1997 a)$ \\
\hline Tax wedge & $\begin{array}{l}\text { Employees' and employers'social security } \\
\text { contributions and personal income tax } \\
\text { less transfer payments as percentage of } \\
\text { gross labour costs. }\end{array}$ & $\begin{array}{l}\text { OECD database on the tax/benefits } \\
\text { position of employees }\end{array}$ \\
\hline Gross replacement rate & $\begin{array}{c}\text { Average gross replacement rate as } \\
\text { percentage of earnings }\end{array}$ & $\begin{array}{l}\text { OECD database on benefit entitlements } \\
\text { and gross replacement rates }\end{array}$ \\
\hline
\end{tabular}

112. A variant of this aggregation formula was used for EU countries, where import-weighted trade barriers are equal, reflecting common trade policies across Member states. The information arising from cross-country import differentials was exploited to generate sample variation in trade barriers within the EU, under the assumption that identical tariff or non-tariff measures have a different economic impact (e.g.

cent of the import-weighted frequency ratio (average import-coverage) of tariff lines were dropped from the sample in regression experiments. Accordingly, three observations have been dropped: Coke, Refined Petroleum and Nuclear Fuel - ISIC 23 - in Japan; Other Non-metallic Mineral Products - ISIC 26 - and Radio Television and Communication Equipment - ISIC 32 - in Norway. 
in terms of distortions) depending on the relative importance of sectors. ${ }^{96}$ The following aggregation scheme was applied:

$$
T_{I, j}=\sum_{x \in I} \frac{\frac{I M P_{x j}}{\sum_{k \in E U} I M P_{x k}}}{\sum_{z \in I} \frac{I M P_{z j}}{\sum_{k \in E U} I M P_{z k}}} T_{x j} \frac{i m p_{x}}{\sum_{y \in I} i m p_{y}}
$$

where IMP stands for actual imports of the EU country $j$. Therefore, normal weights for 6-digit industries were increased or decreased of a percentage that reflects the relative importance of that sector for country $j$ with respect to the EU average.

113. It can be shown that the aggregation scheme described in equation (2) has the following desirable properties: ${ }^{97}$

- The sum of weights is equal to 1 over industry $I$ : hence, if trade barriers are equal for all 6digit subsectors, import-weighted trade barriers are identical to unweighted trade barriers.

- Higher order aggregates of industries can be constructed by an appropriate weighted average where weights are the normalised sum of weights of the corresponding 6-digit sub-sectors.

- Import-weighted trade barriers of any industry for the whole EU can be obtained using an appropriate weighted average where weights for each country, before the re-normalisation, are the sum of weights of the corresponding 6-digit sub-sectors. In other words the weights for aggregating across sectors or across countries are the same.

\section{Other industry-specific product market regulation}

114. The cross-country data on market and industry structure and industry-level product market regulations collected in the context of the OECD Regulatory Reform project (see the data contained in the OECD International Regulation Database and the indicators used in OECD, 2001c) were extended to cover more industries and time periods. The data used in this document cover most of the energy and marketable service industries at the 3 or 4-digit level of ISIC Rev 3 classification (a total of 21 industries and industry aggregates) in (or around 1998) and, for seven of them, the 1975-1998 period. Depending on the industry, the resulting data set covers barriers to entry, public ownership, price controls, government involvement in business operation, market concentration and vertical integration. In network industries -such as utilities, post and telecommunications and railways -- the basic data concerned regulatory and market conditions in different (vertical or horizontal) segments of the industries (e.g. gas production,

96. Import differences across EU countries reflect differences in patterns of preferences or industrial structure and are not the result of trade barriers themselves. In other words, these differences reflect cross-country heterogeneity in the importance of the various sectors.

97. The proof is available from the Secretariat upon request. 
distribution and supply, or regular and express mail). The main sources used to collect the data are the following: ${ }^{98}$

- the OECD: Regulatory Reform, Privatisation and Competition Policy (1992); The OECD International Regulation Database; OECD Roundtables on competition and regulation, various issues; OECD Reviews of Regulatory Reform, various issues; OECD Economic Studies, n.32 (2001) (and background OECD Economics Department Working Papers n. 251, 237, 238, 254, 255); OECD Report on Regulatory Reform (1997)

- the European Conference of Ministers of Transportation: Rail Restructuring in Europe (1998); Regulatory Reforms in the Transport Sector (1987); Competition Policy and Deregulation of Road Transport (1990); Railway Reform (2001);

- the World Bank: Industry Structure and Regulation in Infrastructure: a Cross-Country Survey (1996);

- the European Commission: Liberalisation of Network Industries (1999) (and background documents); Green Paper on Postal Services (1993)

- Center for the Study of Regulated Industries/Privatisation International: I. Lewington (ed.), Utility Regulation (1997);

- Australian Productivity Commission: G. McGuire, M. Schuele and Smith, "Restrictiveness of international trade in maritime services", Productivity Commission Staff Research Paper (2000); K. Kalijaran, "Restrictions on trade in business services", Productivity Commission Staff Research Paper (2000); D. Nguyen-Hong, "Restrictions on trade in professional services", Productivity Commission Staff Research Paper (2000); Trade \& Assistance Review 1998-99 (1999).

Further details about coverage and sources in each of the industries included in the analysis are provided in Table A2.3.

115. As in previous OECD work (Nicoletti et al., 1999), the basic cross-country data were ordered according to a common criterion, reflecting the friendliness of regulations, market structures and industry structures to competition (on a 0-2 scale from least to most restrictive). Furthermore, the resulting cardinal indicators were rescaled to ensure the comparability of the product market indicators across industries. The aim of this operation was to account for structural differences in industry characteristics, such as differences in minimum efficiency scale or vertical and horizontal relationships. ${ }^{99}$ For each regulatory and market dimension covered in the data set, cross-country indicators at the two-digit (ISIC Rev. 3) industry level were constructed by weighting the indices for lower-digit industries with average OECD employment

98. Other sources include the International Energy Agency, the Universal Postal Union and the National Economic Research Associates.

99. For instance, indicators for barriers to entry in each industry were rescaled using the OECD average of the frequency of barriers to entry in that industry. As a result, indicators of barriers to entry in structurally competitive industries (such as retail distribution) take by construction a lower range of values than indicators of barriers to entry in industries having natural monopoly elements (such as electricity). 
shares. ${ }^{100}$ Finally, summary indicators of product market regulation by industry were derived taking the simple average of the regulatory dimensions covered in each industry. ${ }^{101}$

116. To reconstruct a time-series of product market regulation, the data used in this paper covers regulatory and market developments over the 1970-1998 period in seven energy and service industries: gas, electricity, post, telecommunications (mobile and fixed services), passenger air transport, railways (passenger and freight services) and road freight. The coverage of regulatory areas varies across industries. Regulatory barriers to entry are reported for all industries; public ownership is reported in all industries except road freight; vertical integration is documented for gas, electricity and railways; market structure is documented for gas, telecommunications and railways; and price controls are reported for road freight. The aggregate time-series indicator of regulation was constructed by taking a simple average of the summary indicators for the seven industries. ${ }^{102}$ The resulting indicators were interpreted as a proxy for the overall regulatory policies followed by OECD countries over the sample period.

\section{Economy-wide regulatory indicators}

117. All the economy-wide regulatory indicators used in this paper are from the OECD International Regulation Database (see Nicoletti et al., 1999, and OECD, 1999b), except for the time-varying summary indicator of regulation that has been constructed from industry-level data specifically for this project (see above).

100. Aggregation of segments within each industry was made either by simple average (for vertical segments) or with shares in total sales (for horizontal segments). For instance, indicators for postal services were constructed aggregating indicators for ordinary mail, express mail and parcels using the shares of each of these services in total turnover of the post industry.

101. Unlike the economy-wide indicators of product market regulation, the dimensions available for time-series data were too few to be able to aggregate detailed indicators by means of factor analysis.

102. An alternative would have been to aggregate across industries using value added or employment weights. However, value added or employment data at this level of disaggregation are seldom available. More importantly, this would have under-evaluated the reform drive in important industries, such as electricity or telecommunications, which have a relatively low weight but are crucial inputs into overall economic activity. 
Table A2.3. Industry-specific product market regulation: coverage and sources

\begin{tabular}{|c|c|c|c|c|c|c|}
\hline Industry & $\begin{array}{l}\text { ISIC code } \\
\text { Revision } 3\end{array}$ & Period & $\begin{array}{c}\text { Regulatory and } \\
\text { market dimensions } \\
\text { covered }^{1}\end{array}$ & $\begin{array}{l}\text { Industrial segments } \\
\text { covered }\end{array}$ & $\begin{array}{l}\text { Countries } \\
\text { covered }\end{array}$ & Main sources ${ }^{2}$ \\
\hline Electricity & 401 & $\begin{array}{c}1998 \\
1975-1998 \\
\end{array}$ & $\begin{array}{c}\mathrm{P}, \mathrm{E}, \mathrm{PO}, \mathrm{MS}, \mathrm{VI} \\
\mathrm{E}, \mathrm{PO}, \mathrm{VI}\end{array}$ & Prod., Trans., Dist. & $\begin{array}{c}24-25 \\
21\end{array}$ & $\begin{array}{c}\text { OECD } \\
\text { OECD, EC, PI, WB }\end{array}$ \\
\hline Gas manufacture and distribution & 402 & $\begin{array}{c}1998 \\
1975-1998\end{array}$ & $\begin{array}{c}\mathrm{P}, \mathrm{E}, \mathrm{PO}, \mathrm{MS}, \mathrm{VI} \\
\mathrm{E}, \mathrm{PO}, \mathrm{MS}, \mathrm{VI}\end{array}$ & Prod., Trans., Dist. & $\begin{array}{l}26 \\
21\end{array}$ & OECD, EC, PI, WB \\
\hline Energy & 40 & 1998 & $\mathrm{E}, \mathrm{PO}, \mathrm{VI}$ & Prod., Trans., Dist. & 25 & OECD, EC, PI, WB \\
\hline Water works and supply & 41 & 1998 & $\mathrm{E}, \mathrm{PO}, \mathrm{VI}$ & & 23 & OECD, EC, PI, WB \\
\hline Electricity, gas and water & $40 \_41$ & 1998 & $\mathrm{E}, \mathrm{PO}, \mathrm{VI}$ & & 23 & OECD, EC, PI, WB \\
\hline Wholesale trade & 50_51 & 1998 & $\mathrm{E}, \mathrm{PO}$ & & 25 & OECD \\
\hline Retail trade & 52 & 1998 & $\mathrm{E}, \mathrm{CBO}$ & & 28 & OECD \\
\hline Restaurant and hotels & 55 & 1998 & $E$ & & 25 & OECD \\
\hline Railways & 601 & $\begin{array}{c}1998 \\
1975-1998\end{array}$ & $\begin{array}{c}\mathrm{P}, \mathrm{E}, \mathrm{PO}, \mathrm{MS}, \mathrm{VI} \\
\mathrm{E}, \mathrm{PO}, \mathrm{MS}, \mathrm{VI}\end{array}$ & Passenger, freight & $\begin{array}{l}27 \\
21\end{array}$ & OECD, ECMT \\
\hline Road freight & 602 & $\begin{array}{c}1998 \\
1975-1998\end{array}$ & $\begin{array}{c}P, E, C B O \\
P, E\end{array}$ & & $\begin{array}{c}27-29 \\
21\end{array}$ & $\begin{array}{c}\text { OECD } \\
\text { OECD, ECMT }\end{array}$ \\
\hline Land transport & 60 & 1998 & $P, E$ & & 27 & OECD, ECMT \\
\hline Water transport & 61 & 1998 & $\mathrm{E}, \mathrm{CBO}$ & & 22 & APC \\
\hline Air transport carriers & 62 & $\begin{array}{c}1998 \\
1975-1998\end{array}$ & $\begin{array}{c}\mathrm{E}, \mathrm{PO}, \mathrm{MS} \\
\mathrm{E}, \mathrm{PO}\end{array}$ & Passenger & $\begin{array}{l}27 \\
21\end{array}$ & $\begin{array}{c}\text { OECD } \\
\text { OECD, EC }\end{array}$ \\
\hline Transport & $60 \_62$ & 1998 & $E$ & & 22 & $\begin{array}{l}\text { OECD, ECMT } \\
\text { EC, APC }\end{array}$ \\
\hline Supporting services to transport & 63 & 1998 & $\mathrm{E}, \mathrm{PO}$ & & 21 & OECD \\
\hline Post & 641 & $\begin{array}{c}1998 \\
1975-1998 \\
\end{array}$ & $\mathrm{P}, \mathrm{E}, \mathrm{PO}, \mathrm{VI}$ & Letter, parcel, express & $\begin{array}{c}22-26 \\
21\end{array}$ & OECD, EC, UPU \\
\hline Telecoms & 642 & $\begin{array}{c}1998 \\
1975-1998 \\
\end{array}$ & $\begin{array}{c}\mathrm{P}, \mathrm{E}, \mathrm{PO}, \mathrm{MS}, \mathrm{VI} \\
\mathrm{E}, \mathrm{PO}, \mathrm{MS}\end{array}$ & Fixed, mobile & $\begin{array}{c}20-29 \\
21\end{array}$ & OECD \\
\hline Communication & 64 & 1998 & $\mathrm{P}, \mathrm{E}, \mathrm{PO}, \mathrm{MS}$ & & 26 & OECD \\
\hline Financial institutions & 65 & 1998 & $\mathrm{E}, \mathrm{CBO}$ & & 23 & OECD, APC \\
\hline Insurance & 66 & 1998 & $P, E$ & Life, general, health & 12 & OECD \\
\hline Legal services & 7411 & 1998 & $\mathrm{E}, \mathrm{CBO}$ & & 22 & APC \\
\hline Accounting services & 7412 & 1998 & $\mathrm{E}, \mathrm{CBO}$ & & 23 & APC \\
\hline $\begin{array}{l}\text { Architectural and engineering } \\
\text { services }\end{array}$ & 7421 & 1998 & $\mathrm{E}, \mathrm{CBO}$ & & 23 & APC \\
\hline Professional business services & 74 & 1998 & $\mathrm{E}, \mathrm{CBO}$ & & 22 & APC \\
\hline $\begin{array}{l}\text { Note 1: } \\
\qquad \begin{aligned} \mathrm{P} & =\text { Price regulation } \\
\mathrm{E} & =\text { Barriers to entry } \\
\mathrm{PO} & =\text { Public ownership } \\
\mathrm{CBO} & =\text { Constraints to business ope } \\
\mathrm{MS} & =\text { Market structure } \\
\mathrm{VI} & =\text { Vertical integration }\end{aligned}\end{array}$ & eration & & $\begin{array}{l}\text { Note 2: } \\
\qquad \begin{aligned} \text { ECMT } & =\text { European } \\
\text { EC } & =\text { European C } \\
\text { WB } & =\text { World Bank } \\
\text { PI } & =\text { Privatisatio } \\
\text { APC } & =\text { Australian } \\
\text { UPU } & =\text { Universal P }\end{aligned}\end{array}$ & $\begin{array}{l}\text { onference of Ministers of } \\
\text { ommission } \\
\text { International } \\
\text { roductivity Commission } \\
\text { stal Union }\end{array}$ & ransportation & \\
\hline
\end{tabular}

Source: Jean and Nicoletti (2001). 


\section{REFERENCES}

ACS, Z. and D. AUDRETSCH (1989), "Patents as a Measure of Innovative Activity", Kyklos, Vol. 42, pp. 171-180.

ARNAL, E., W. OK and R. TORRES (2001), "Knowledge, Work Organisation and Economic Growth", Labour Market and Social Policy Occasional Papers, No. 50, OECD, Paris.

AUDRETSCH, D. (1995), Innovation and Industry Evolution, Cambridge: Mass.: The MIT Press.

AUDRETSCH, D. and R. THURIK (2001), "Linking Entrepreneurship to Growth", STI Working Papers 2001/2, OECD, Paris.

BLACK, S. and L. LYNCH (2000), "What's Driving the New Economy: The Benefits of Workplace Innovation", NBER Working Paper No. 7479.

BOOTH, A., M. BURDA, L. CALMFORS, D. CHECCHI, R. NAYLOR and J. VISSER (2000), "What do unions do in Europe? Prospects and challenges for union presence and union influence", Report for the Fondazione Rodolfo Debenedetti.

BRESNAHAN, T. (2001), "The Mechanism of Information Technology's Contribution to Economic Growth", presented at the conference "What do we know about the sources of technical change?", Saint-Gobain Centre for Economic Research, Paris, June.

BRESNAHAN, T., E. BRYNJOLFSSON and L. HITT (2001), "Information Technology, Workplace Organization and the Demand for Skilled Labor: Firm-Level Evidence", Quarterly Journal of Economics, forthcoming.

CAROLI, E., and J. VAN REENEN (2001), "Skill Biased Organizational Change? Evidence from a Panel of French and British Establishments", Quarterly Journal of Economics, forthcoming.

EBBINGHAUS, B. and J. VISSER (2000), The Societies of Europe. Trade Unions in Western Europe since 1945, MacMillan, London,.

ELMESKOV, J., J. MARTIN and S. SCARPETTA (1998), "Key Lessons for Labour Market Reforms: Evidence from OECD Countries' Experiences", Swedish Economic Policy Review, Vol. 5, pp. 205252.

GRILICHES, Z. (1990), "Patent Statistics as Economic Indicators: A Survey", Journal of Economic Literature, Vol. 28, pp. 1661-1797.

JEAN, S. and G. NICOLETTI (2001), "Product market regulation and wage premia in Europe and NorthAmerica: An empirical investigation", OECD Economics Department Working Paper, forthcoming, Paris. 
NICOLETTI, G., S. SCARPETTA and O. BOYLAUD (1999), "Summary Indicators of Product Market Regulation with an Extension to Employment Protection Legislation", OECD Economics

Department Working Papers, $\mathrm{N}^{\mathrm{o}} 226$.

OECD (1997b), Indicators of Tariff and Non-tariff Trade Barriers, Paris.

OECD (1999a), Employment Outlook, Paris.

OECD (1999b), "Cross-country patterns of product market regulation", OECD Economic Outlook, n.66, Paris.

OECD (2000a), Science, Technology and Industry Outlook, Paris.

OECD (2000b), Employment Outlook, Paris.

OECD (2001a), "Productivity and Firm Dynamics: Evidence from Micro-Data", OECD Economic Outlook n.69, Paris.

OECD (2001b), Employment Outlook, Paris.

OECD (2001c), OECD Economic Studies, n. 32, Paris.

SCHERER, F.M. (1983), “The Propensity to Patent”, International Journal of Industrial Organization, Vol. 1, pp. 107-128.

WATSON WYATT Worldwide (1997), Employment Terms and Conditions: Europe, Brussels: Watson Wyatt. 
ANNEX 2. STATISTICAL DETAILS

\section{Empirical methodology}

\subsection{Panel regression methods}

118. In cross-country/time-series regressions units of observation (countries) are repeated over time. In cross-country/cross-industry regressions each data point (a country-industry couple) is a different unit of observation. However in cross-country/cross-industry regressions some variables may be defined only along the country or industry dimension (such as macroeconomic variables in a cross-country/crossindustry model). Hence, these variables take the same value on clusters of observations. The use of OLS to estimate models with repeated units of observation or variables that take the same value on clusters of observations can yield biased and inconsistent estimates of coefficients and/or standard errors (Moulton, 1986).

119. A simple solution is to add dummies to control for repeated units or clusters of observations (e.g. country or industry fixed effects). However, in this approach the effects of variables that are constant on clusters of observations cannot be analysed (because they are subsumed into the dummies). Alternatively, these effects can be appropriately estimated by including the corresponding variables, adjusting for clustering the standard errors of the OLS coefficient estimates. A third solution consists in estimating a random-effects specification by GLS. In this specification the units of observation are assumed to constitute a random sample and the cluster-specific effects (e.g. country-specific effects) are assumed to be independently-distributed random variables with mean zero and constant variance.

120. Conceptually, the random-effects specification would seem more apt to deal with large micro-data sets (e.g. where individuals are households or firms), while the fixed-effects specification would seem to be more appropriate in the case of cross-country data. However, the choice between the two specifications can only be made on a case-by-case basis. If the hypotheses of the random-effects specification are correct, the corresponding estimator is more efficient than the fixed-effects estimator. Conversely, if the random effects are correlated with the other explanatory variables (often the case when the hypothesis of random sampling fails to hold), the corresponding estimator will be biased and inconsistent. Similarly if the equation is estimated with cluster-adjusted OLS but not all cluster-specific variables are included in the regression, the estimator might be biased and inconsistent (as in any omittedvariable specification).

121. Several tests have been designed to help discriminating among different methods. In this paper, three tests are provided. A simple F-test is used to test the null hypothesis that there are no fixed unit/cluster-specific effects in the data. The test resulting into a rejection implies that the simple linear model is incorrect and the OLS estimator with no adjustment is biased and spurious. Similarly, the Breusch-Pagan test, can be applied to test the random-effects specification against the simple linear model with or without adjustment for clustering. Finally, the Hausman test makes it possible to verify the 
hypothesis that the random effects are uncorrelated with the explanatory variables. If the test-statistic is significant, the random-effects specification is incorrect and either a fixed effect or a cluster-adjusted estimator must be applied.

\subsection{Treatment of outliers}

122. Different measures for the identification and control of outliers have been used. They are essentially based on the residual and leverage ${ }^{103}$ of each observation. The simplest possible indicator is the studentised residual of each observation $i$, which corresponds to the t-statistics of a dummy variable for $i$ that has been added to the original regression equation. Although appealing and quite intuitive, this statistics tends to eliminate observations with large residual but low leverage that do not influence the estimated coefficient very much (that is in the case where the dummy variable is orthogonal to the other regressors), biasing upwards goodness-of-fit statistics. Other more complex indicators are based on the notion of influence curve. The influence curve assesses the asymptotic marginal effect of adding a specific observation $i$ on the coefficient estimates, on the basis of the original regression model. The influence curve is an asymptotic concept. However, the DFITS or Welsch-Kuh distance and the Welsch distance are two indicators (used in this paper) that try to approximate empirically the influence curve and detect influential observations from it (see Chatterjee and Hadi, 1988).

\section{Decomposition of within and between-industry effects and specialisation indicators}

\subsection{Decomposition}

123. The following methodology has been used to decompose the deviation of R\&D intensity and firm size from the OECD average into within-industry and industry-composition effects. The aggregate ratio between $\mathrm{R} \& \mathrm{D}(\mathrm{RD})$ and output $(\mathrm{Y})$ can be broken down into its industry components as:

$$
\left(\frac{R D}{Y}\right)_{i}=\sum_{k}\left(\frac{R D_{k i}}{Y_{k i}}\right) \cdot\left(\frac{Y_{k i}}{Y_{i}}\right) \text { for each country i and industry k. }
$$

124. Using the deviation from the mean of OECD countries and assuming that the panel is balanced, this can be rewritten as:

$$
\begin{aligned}
\left(\frac{R D_{i}}{Y_{i}}\right)-\frac{1}{N} \sum_{j \in O E C D} \frac{R D_{j}}{Y_{j}}= & \overbrace{\frac{1}{2 N} \sum_{j \in O E C D} \sum_{k}\left(\frac{R D_{k i}}{Y_{k i}}-\frac{R D_{k j}}{Y_{k j}}\right)\left(\frac{Y_{k i}}{Y_{\cdot i}}+\frac{Y_{k j}}{Y_{\cdot j}}\right)+}^{\text {within effect }} \\
& +\underbrace{\frac{1}{2 N} \sum_{j \in O E C D} \sum_{k}\left(\frac{R D_{k i}}{Y_{k i}}+\frac{R D_{k j}}{Y_{k j}}\right)\left(\frac{Y_{k i}}{Y_{\cdot i}}-\frac{Y_{k j}}{Y_{\cdot j}}\right)}_{\text {between effect }}
\end{aligned}
$$

where $\mathrm{N}$ is the number of OECD countries for which data are available, $\mathrm{i}$ and $\mathrm{j}$ are country indices, and a dot indicates summation over the correpsonding index.

103. The leverage measures the distance of an observation from the center of the data. 
125. The actual decomposition formula used in the paper accounts for the fact that the panel data used are unbalanced, due to missing observations in some countries. Restricting the analysis to countries where manufacturing aggregates for $R \& D$ intensity and output are available, denoting by NA the set of $(\mathrm{k}, \mathrm{i})$ variables for which data for one of the variables is missing and by A the complement of NA, the following modified formula applies:

$$
\begin{aligned}
\left(\frac{R D_{i}}{Y_{i}}\right)-\frac{1}{N} \sum_{j \in O E C D} \frac{R D_{j}}{Y_{j}}= & \overbrace{\frac{1}{2 N} \sum_{(k, i) \wedge(k, j) \in A}\left(\frac{R D_{k i}}{Y_{k i}}-\frac{R D_{k j}}{Y_{k j}}\right)\left(\frac{Y_{k i}}{Y_{\cdot i}}+\frac{Y_{k j}}{Y_{\cdot j}}\right)+}^{\text {available part of the within effect }} \\
& +\underbrace{\left.\frac{1}{2 N} \sum_{(k, i) \wedge(k, j) \in A}\left(\frac{R D_{k i}}{Y_{k i}}+\frac{R D_{k j}}{Y_{k j}}\right) \frac{Y_{k i}}{Y_{\cdot i}}-\frac{Y_{k j}}{Y_{\cdot j}}\right)}_{\text {available part of the between effect }}+ \\
& +\underbrace{\frac{1}{N} \sum_{(k, i)(k, j) \in N A}\left(\frac{R D_{k i}}{Y_{\cdot}}-\frac{R D_{k j}}{Y_{\cdot j}}\right)}_{\text {residual, not computable due to missing data }}
\end{aligned}
$$

In Figure 3 the residual element has been alloted to the within- and between-effects in proportion to their relative size.

126. A similar formula has been applied to decompose the deviations of firm size in each country from average OECD values into within-industry and industry-composition effects.

\subsection{Specialisation in high-R\&D and high-wage industries}

127. The analysis of industry specialisation (see Figure 5) is based on indicators that weight average industry characteristics across OECD countries (e.g. industry wage premia) with the employment structure of each country. For a given country, the indicators are calculated using the following formula:

$$
I_{i}=100 \cdot \sum_{k} w_{k i}\left[1-\frac{\max \left(X_{k}\right)-X_{k}}{\max \left(X_{k}\right)-\min \left(X_{k}\right)}\right]
$$

where $\mathrm{i}$ and $\mathrm{k}$ are country and industry indices, respectively; $\mathrm{I}_{\mathrm{i}}$ is the specialisation indicator for country $\mathrm{i}$; $\mathrm{w}_{\mathrm{ki}}$ is the weight attributed to employment in sector s in country $\mathrm{i}$; $\max (\mathrm{X})$ is the maximum value of the sectoral characteristic $X ; \min (X)$ is the minimum value of sectoral characteristic $X$; and $X_{k}$ is the value of characteristic $\mathrm{X}$ in sector $\mathrm{k}$. By construction, the specialisation indicator ranges between 0 and 100 and the higher its value the more specialised is the country in industries having high $\mathrm{X}$ values.

128. Since industry coverage was incomplete for some countries, the following approximations have been made in order to be able to compare countries having the same sectoral coverage:

- for a given country, missing weights for a set of industries have been replaced by average OECD relative weights within the same set of industries when at least 75 per cent of overall employment was covered by available data; 
- for countries in which the industry breakdown was insufficient, the employment distribution across branches of the industry aggregate for which data were available were assumed to be equal to the distribution observed in the average OECD country.

\section{Additional background material and empirical results}

\subsection{Data samples}

129. Table A3.1 decribes the samples used in each of the regressions presented in.

\subsection{R\&D}

130. The analysis presented in the paper has been tested for sensitivity to the change of certain indicators as well as for misspecification. This section reports three sets of results: specification tests of the basic R\&D equation; regressions using the corporatism indicator instead the co-ordination indicator; and the regression underlying the derived coefficients in Table 7.

131. A standard F-test was used to test the null of the linear model against the alternative of the nonlinear specification. To check the robustness of the result, the non-nested testing procedure of Davidson and McKinnon (1981) was performed to test the null of the non-linear model against the alternative of the linear specification (Table A3.2). Taken together these results show that the non-linear specification must be preferred to the linear one.

132. Table A3.3 shows regression results when corporatism is used instead of co-ordination in the same model specifications as in Table 6. Substituting corporatism for co-ordination yields very similar estimates confirming that the particularly low value for wage-bargaining co-ordination in Japan - the only difference between the two indicators - is not driving regression results. In particular, the policy interactions between EPL and the industrial relation regime (as measured by corporatism in this context) confirm the earlier results. The same applies to the outcomes of the Breusch-Pagan and Hausman tests.

133. Table A3.4 presents the full regression results that have been used to determine the effect of an increase of EPL under different bargaining systems (Table 7). The first column shows the results that have been retained for Table 7. The second column tests the sensitivity of these results to the control for average firm size, which may be considered to be endogenous to R\&D. Dropping size does not affect the results presented in Table 7 substantially. Nevertheless, EPL now has a significant positive effect in high-tech industries in countries with high bargaining co-ordination. 
Table A3.1. Samples used in empirical analysis

Panel A : R\&D, Size, Wage premia, Employment

\begin{tabular}{|c|c|c|c|c|c|c|c|c|}
\hline \multirow{2}{*}{$\begin{array}{l}\text { R\&D intensity } \\
\text { average } 1993-97\end{array}$} & \multicolumn{3}{|c|}{ Countries } & \multicolumn{3}{|c|}{ Industries } & \multicolumn{2}{|c|}{ Outliers } \\
\hline & $\begin{array}{l}\text { AUT } \\
\text { BEL } \\
\text { CAN } \\
\text { DEU } \\
\text { DNK } \\
\text { ESP }\end{array}$ & $\begin{array}{l}\text { FIN } \\
\text { FRA } \\
\text { GBR } \\
\text { GRC } \\
\text { IRL } \\
\text { ITA }\end{array}$ & $\begin{array}{l}\text { JPN } \\
\text { NLD } \\
\text { NOR } \\
\text { PRT } \\
\text { SWE } \\
\text { USA }\end{array}$ & $\begin{array}{c}\mathrm{Bm} \\
\mathrm{Ch} \\
\mathrm{Cpn} \\
\mathrm{Em} \\
\mathrm{Fbt} \\
\mathrm{Fm}\end{array}$ & $\begin{array}{c}\mathrm{Me} \\
\mathrm{Mo} \\
\mathrm{Mv} \\
\mathrm{Nm} \\
\mathrm{Oac} \\
\mathrm{P}\end{array}$ & $\begin{array}{l}\mathrm{Pp} \\
\mathrm{Rp} \\
\text { Rtc } \\
\text { Te } \\
\text { Twl } \\
\text { Wo }\end{array}$ & $\begin{array}{l}\text { BEL (Mv) } \\
\text { GBR (Cpn) } \\
\text { GRC (Te) } \\
\text { IRL (Wo) }\end{array}$ & $\begin{array}{l}\text { IRL (Oac) } \\
\text { JPN (Twl) } \\
\text { NLD (Em) }\end{array}$ \\
\hline $\begin{array}{l}\text { Size } \\
\text { average 1993-96 }\end{array}$ & $\begin{array}{l}\text { AUT } \\
\text { BEL } \\
\text { CAN } \\
\text { DEU } \\
\text { DNK } \\
\text { ESP }\end{array}$ & $\begin{array}{l}\text { FIN } \\
\text { FRA } \\
\text { GBR } \\
\text { IRL } \\
\text { ITA } \\
\text { JPN }\end{array}$ & $\begin{array}{l}\text { NLD } \\
\text { NOR } \\
\text { PRT } \\
\text { SWE } \\
\text { USA }\end{array}$ & $\begin{array}{l}\mathrm{Bm} \\
\mathrm{Ch} \\
\mathrm{Cpn} \\
\mathrm{Em} \\
\mathrm{Fbt} \\
\mathrm{Fm}\end{array}$ & $\begin{array}{c}\mathrm{Me} \\
\mathrm{Mo} \\
\mathrm{Mv} \\
\mathrm{Nm} \\
\mathrm{Oac} \\
\mathrm{P}\end{array}$ & $\begin{array}{c}\mathrm{Pp} \\
\mathrm{Rp} \\
\text { Rtc } \\
\text { Te } \\
\text { Twl } \\
\text { Wo }\end{array}$ & $\begin{array}{l}\text { BEL (Wo) } \\
\text { CAN (Wo) } \\
\text { FIN (Wo) }\end{array}$ & $\begin{array}{l}\text { IRL (Wo) } \\
\text { NLD (Wo) } \\
\text { NOR (Mv) }\end{array}$ \\
\hline $\begin{array}{c}\text { Manufacturing } \\
\text { Collective } \\
\text { dismissals }\end{array}$ & $\begin{array}{l}\text { AUT } \\
\text { BEL } \\
\text { CAN } \\
\text { CZE } \\
\text { DEU } \\
\text { DNK }\end{array}$ & $\begin{array}{c}\text { ESP } \\
\text { FIN } \\
\text { FRA } \\
\text { GBR } \\
\text { GRC } \\
\text { IRL }\end{array}$ & $\begin{array}{l}\text { ITA } \\
\text { JPN } \\
\text { NLD } \\
\text { NOR } \\
\text { PRT } \\
\text { SWE } \\
\text { USA }\end{array}$ & $\begin{array}{l}\mathrm{Bm} \\
\mathrm{Ch} \\
\mathrm{Cpn} \\
\mathrm{Em} \\
\mathrm{Fbt} \\
\mathrm{Fm}\end{array}$ & $\begin{array}{c}\mathrm{Me} \\
\mathrm{Mo} \\
\mathrm{Mv} \\
\mathrm{Nm} \\
\mathrm{Oac} \\
\mathrm{P}\end{array}$ & $\begin{array}{l}\text { Pp } \\
\text { Rp } \\
\text { Rtc } \\
\text { Te } \\
\text { Twl } \\
\text { Wo }\end{array}$ & $\begin{array}{c}\text { BEL (Cpn) } \\
\text { CZE (Mv) } \\
\text { DEU (Oac) } \\
\text { GBR (Cpn) }\end{array}$ & $\begin{array}{l}\text { NLD (Cpn) } \\
\text { NLD (Oac) } \\
\text { NZL (Ch) }\end{array}$ \\
\hline Non-manufacturing & $\begin{array}{l}\text { AUT } \\
\text { BEL } \\
\text { CHE } \\
\text { DEU } \\
\text { DNK }\end{array}$ & $\begin{array}{c}\text { ESP } \\
\text { FIN } \\
\text { FRA } \\
\text { GBR } \\
\text { ITA }\end{array}$ & $\begin{array}{l}\text { NLD } \\
\text { NOR } \\
\text { NZL } \\
\text { PRT } \\
\text { SWE } \\
\text { USA }\end{array}$ & $\begin{array}{l}\text { At } \\
E G \\
H R\end{array}$ & $\begin{array}{l}\mathrm{Lt} \\
\mathrm{OB} \\
\mathrm{Ot}\end{array}$ & $\begin{array}{c}\text { PT } \\
\text { R } \\
\text { W } \\
W t\end{array}$ & $\begin{array}{l}\text { AUT (HR) } \\
\text { CHE (OB) }\end{array}$ & $\begin{array}{l}\text { DNK (Lt) } \\
\text { ITA (R) }\end{array}$ \\
\hline Manufacturing & $\begin{array}{l}\text { AUT } \\
\text { BEL } \\
\text { DNK } \\
\text { ESP }\end{array}$ & $\begin{array}{c}\text { FRA } \\
\text { GBR } \\
\text { GRC } \\
\text { IRL }\end{array}$ & $\begin{array}{l}\text { ITA } \\
\text { SWE } \\
\text { USA }\end{array}$ & $\begin{array}{l}\mathrm{Bm} \\
\mathrm{Ch} \\
\mathrm{Cpn} \\
\mathrm{Em} \\
\mathrm{Fb} \\
\mathrm{Fm} \\
\text { Lea }\end{array}$ & $\begin{array}{c}\mathrm{Me} \\
\mathrm{Mo} \\
\mathrm{Mv} \\
\mathrm{Nm} \\
\mathrm{Oac} \\
\mathrm{P} \\
\mathrm{Pp}\end{array}$ & $\begin{array}{c}\text { Rp } \\
\text { Rtc } \\
\text { Te } \\
\text { Tex } \\
\text { To } \\
\text { Wo } \\
\text { We }\end{array}$ & $\begin{array}{c}\text { BEL (To) } \\
\text { FRA (Wo, Mv) } \\
\text { GBR (Oac) }\end{array}$ & $\begin{array}{c}\text { GRC (Te) } \\
\text { ITA (To) } \\
\text { USA (Pp, Mv) }\end{array}$ \\
\hline Non-manufacturing & $\begin{array}{l}\text { AUT } \\
\text { BEL } \\
\text { CAN } \\
\text { DNK }\end{array}$ & $\begin{array}{l}\text { ESP } \\
\text { FRA } \\
\text { GBR } \\
\text { GRC }\end{array}$ & $\begin{array}{l}\text { IRL } \\
\text { ITA } \\
\text { SWE } \\
\text { USA }\end{array}$ & $\begin{array}{c}\text { At } \\
E G \\
F \\
H R\end{array}$ & $\begin{array}{c}\mathrm{I} \\
\mathrm{Lt} \\
\mathrm{OB} \\
\mathrm{Ot}\end{array}$ & $\begin{array}{c}\text { PT } \\
R \\
W \\
W t\end{array}$ & ESP & $(\mathrm{Wt})$ \\
\hline Employment, 1982-98 & $\begin{array}{l}\text { AUS } \\
\text { AUT } \\
\text { BEL } \\
\text { CAN } \\
\text { DEU } \\
\text { DNK } \\
\text { ESP }\end{array}$ & $\begin{array}{c}\text { FIN } \\
\text { FRA } \\
\text { GBR } \\
\text { GRC } \\
\text { IRL } \\
\text { ITA } \\
\text { JPN }\end{array}$ & $\begin{array}{l}\text { NLD } \\
\text { NOR } \\
\text { NZL } \\
\text { PRT } \\
\text { SWE } \\
\text { USA }\end{array}$ & & & & $\begin{array}{c}\text { IRL } \\
\text { JPN } \\
\text { NOF } \\
\text { NZL } \\
\text { NZL }\end{array}$ & $\begin{array}{l}(98) \\
(98) \\
(88) \\
(82) \\
(94)\end{array}$ \\
\hline
\end{tabular}

Manufacturing :

$\mathrm{Bm}$ : Basic metals

$\mathrm{Ch}$ : Chemicals

$\mathrm{Cpn}:$ Coke, petroleum products
$\mathrm{Em}$ : Electrical machinery n.e.c.

$\mathrm{Fb}$ : Food products and beverages

Fbt : Food products, beverages and tobacco

Fm : Metal products, except machinery and eq.

Lea : Dressing of leather, luggage

$\mathrm{Me}$ : Machinery and equipment n.e.c.

Mo : Medical, optical instruments

Mv : Motor vehicles

$\mathrm{Nm}$ : Other non-metallic mineral products

Non-manufacturing :

At : Air transport

EG : Electricity, Gas

$F \quad$ : Financial intermediation
Oac : Office machinery, computers

$\mathrm{P} \quad$ : Pulp, paper and paper products

Pp : Publishing, printing

$\mathrm{Rp}:$ Rubber and plastics products

Rtc : Radio, television, communication eq.

$\mathrm{Te}$ : Other transport equipment

Tex : Textiles

To : Tobacco

Twl : Textiles, wearing apparel, leather

Wo : Wood, except furniture

We : Wearing apparel, dyeing of fur

Ot : Auxiliary trans. activities

PT : Post, Telecommunications

$R$ : Retail trade 
ECO/WKP(2001)38

Table A3.1. Samples used in empirical analysis (continued)

Panel B : Insecurity, Inequality

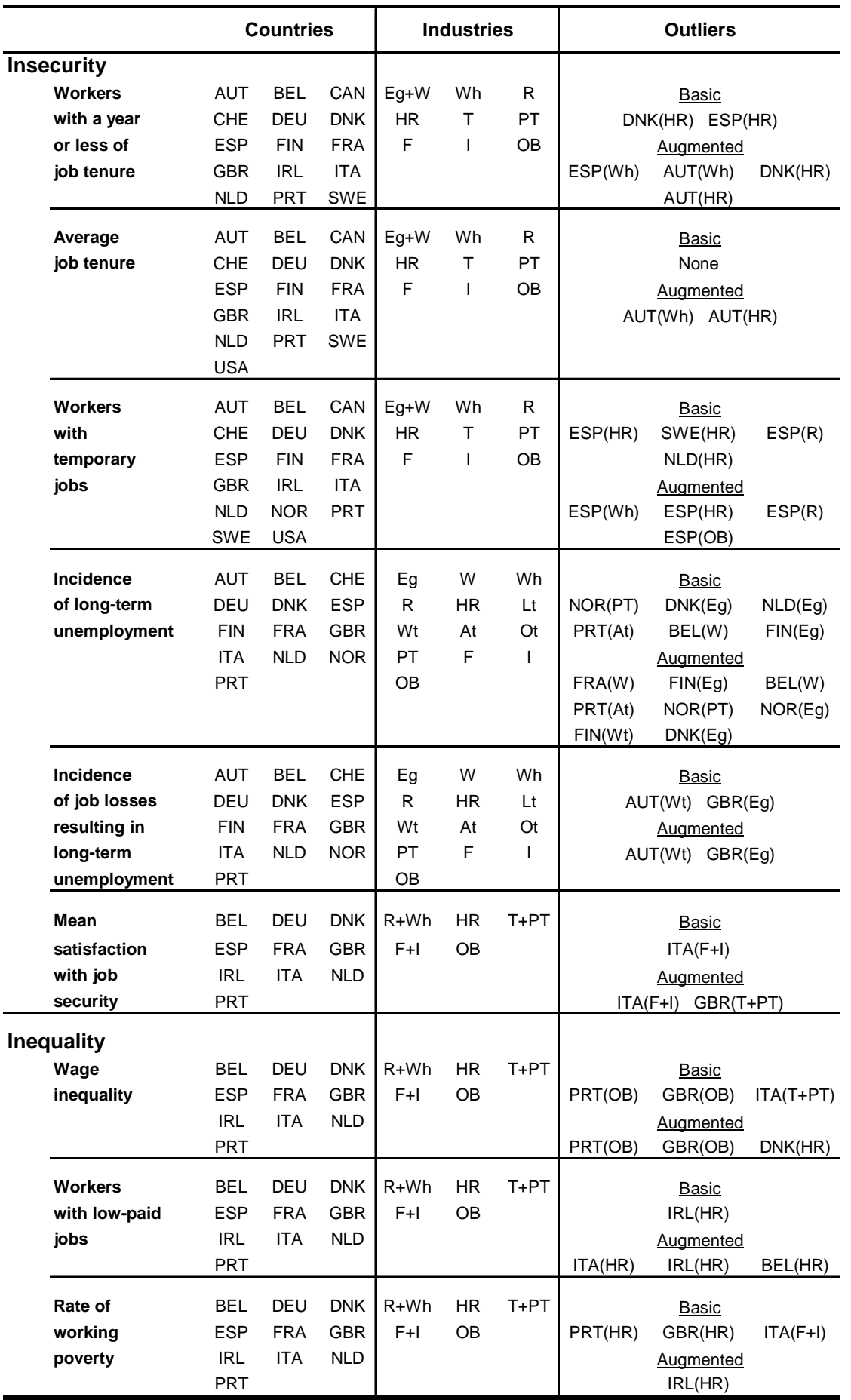

At : Air transport

EG : Electricity, Gas

$F$ : Financial intermediation

HR : Hotels, Restaurants

I : Insurance

Lt : Land transport

OB : Other business activities
Ot : Auxiliary trans. activities

PT : Post, Telecommunications

$\mathrm{R}$ : Retail trade

$T$ : Transport

W : Water

Wh : Wholesale trade

Wt : Water transport 


\section{Table A3.2. Tests of interaction hypotheses}

Results of nested and non-nested tests ${ }^{1}$

\begin{tabular}{lcc}
\hline & \multicolumn{2}{c}{ Alternative hypothesis } \\
\cline { 2 - 3 } & $\begin{array}{c}\text { Unrestricted } \\
\text { coordination }\end{array}$ & $\begin{array}{c}\text { Linear } \\
\text { interactions }\end{array}$ \\
\cline { 2 - 3 } & & \\
Null hypothesis & - & 0.957 \\
Unrestricted coordination & $17.77^{2}$ & $(0.34)$ \\
Linear interactions & $(0.001)$ & - \\
\hline
\end{tabular}

1. The table reports $T$-values ( $P$-values in parentheses) of the Davidson-McKinnon test for non-nested hypotheses and the F-test in the case of nested hypotheses. Samples are adjusted for outliers based on the Welsch distance cut-off (Chatterjee and Hadi, 1988).

2. Significant at the $1 \%$ level. 
ECO/WKP(2001)38

Table A3.3. Effects of policies and institutions on R\&D intensity : sensitivity analysis Replacing coordination by corporatism

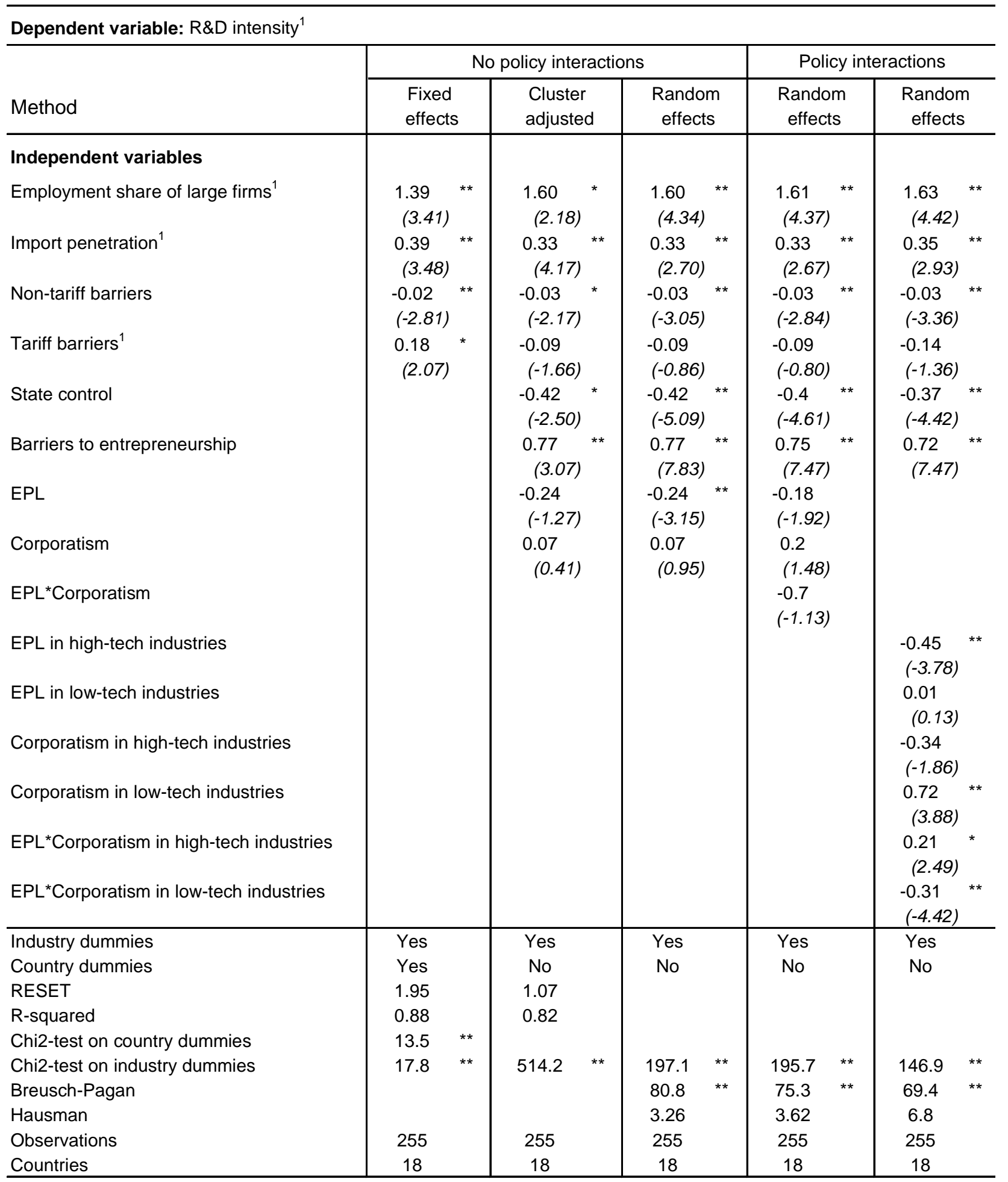

1. In logarithm

Note: All equations includes a constant. *, ${ }^{* *}$ denote significance at the $5 \%, 1 \%$ level, respectively. T-statistics in parenthes Samples are adjusted for outliers based on the Welsch distance cut-off (Chatterjee and Hadi, 1988). High-tech industries corresponds to industries 24 and 29-35 of the ISIC Rev. 3 classification. 
Table A3.4. Net effects of policies and institutions on R\&D intensity : underlying regressions and sensitivity analysis

Results of random-effects panel regressions

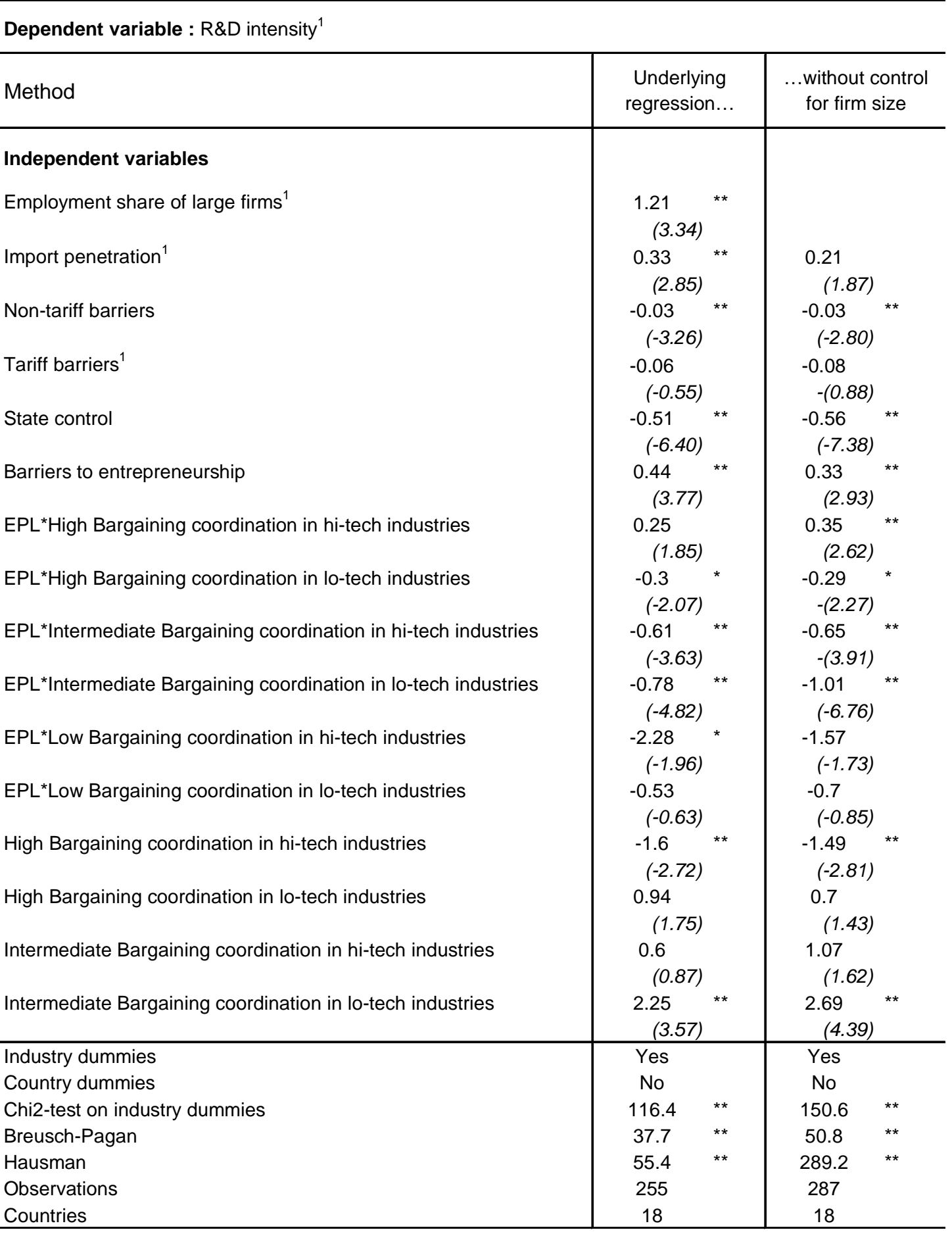

\section{In logarithm}

Note: All equations includes a constant. * ${ }^{* *}$ denote significance at the $5 \%, 1 \%$ level, respectively. T-statistics in parentheses. Samples are adjusted for outliers based on the Welsch distance cut-off (Chatterjee and Hadi, 1988).

High-tech industries corresponds to industries 24 and 29-35 of the ISIC Rev. 3 classification. 


\subsection{Wage premia}

134. Table A3.5 shows the earning profiles estimated from the data on hourly earnings of full-time workers. The Table contains coefficient estimates from an ANOVA model regressing hourly earnings of full-time workers on gender, age and education dummies as well as (in parenthesis) the share of each group of workers in total employment (see Jean and Nicoletti, 2001). Coefficient estimates for each worker characteristic should be interpreted as percentage variations relative to the (omitted) benchmark characteristic. For instance, regression results indicate that earnings of female workers are between 11 per cent (Sweden) and 25 per cent (United Kingdom) lower than those of male workers. Results for age and education are also generally consistent with standard "Mincerian" equations, with earnings increasing with age and education levels.

Table A3.5. Estimates of earnings profiles ("mincerian" equations)

Wages and observable workers characteristics

(estimated on a hourly basis for full-time workers)

\begin{tabular}{|c|c|c|c|c|c|c|c|c|c|c|c|c|}
\hline & Austria & Belgium & Canada & Denmark & France & Greece & Ireland & Italy & Spain & Sweden & $\begin{array}{l}\text { United } \\
\text { Kingdom }\end{array}$ & $\begin{array}{l}\text { United } \\
\text { States }\end{array}$ \\
\hline \multicolumn{13}{|c|}{ Gender } \\
\hline Male & $\begin{array}{l}- \\
(0.65)\end{array}$ & $\begin{array}{l}- \\
(0.69)\end{array}$ & $\begin{array}{l}- \\
(1.00)\end{array}$ & $\begin{array}{l}- \\
(0.63)\end{array}$ & $\begin{array}{l}- \\
(0.67)\end{array}$ & $\begin{array}{l}- \\
(0.64)\end{array}$ & $\begin{array}{l}- \\
(0.58)\end{array}$ & $\begin{array}{l}- \\
(0.71)\end{array}$ & $\begin{array}{l}- \\
(0.75)\end{array}$ & $\begin{array}{l}- \\
(0.70)\end{array}$ & $\begin{array}{l}- \\
(0.58)\end{array}$ & $\begin{array}{l}- \\
(0.61)\end{array}$ \\
\hline Female & $\begin{array}{l}-0.24 \\
(0.35)\end{array}$ & $\begin{array}{l}-0.16 \\
(0.31)\end{array}$ & $\begin{array}{l}-0.23 \\
(0.00)\end{array}$ & $\begin{array}{l}-0.14 \\
(0.37)\end{array}$ & $\begin{array}{l}-0.21 \\
(0.33)\end{array}$ & $\begin{array}{c}-0.19 \\
(0.36)\end{array}$ & $\begin{array}{l}-0.18 \\
(0.42)\end{array}$ & $\begin{array}{l}-0.17 \\
(0.29)\end{array}$ & $\begin{array}{l}-0.19 \\
(0.25)\end{array}$ & $\begin{array}{l}-0.11 \\
(0.30)\end{array}$ & $\begin{array}{l}-0.25 \\
(0.42)\end{array}$ & $\begin{array}{l}-0.20 \\
(0.39)\end{array}$ \\
\hline \multicolumn{13}{|c|}{ Age } \\
\hline $15-24$ & $\begin{array}{l}- \\
(0.16)\end{array}$ & $\begin{array}{l}- \\
(0.10)\end{array}$ & $\begin{array}{l}- \\
(0.00)\end{array}$ & $\begin{array}{l}- \\
(0.20)\end{array}$ & $\begin{array}{l}- \\
(0.12)\end{array}$ & $\begin{array}{l}- \\
(0.11)\end{array}$ & $\begin{array}{l}- \\
(0.22)\end{array}$ & $\begin{array}{l}- \\
(0.10)\end{array}$ & $\begin{array}{l}- \\
(0.09)\end{array}$ & $\begin{array}{l}- \\
(0.08)\end{array}$ & $\begin{array}{l}- \\
(0.15)\end{array}$ & $\begin{array}{l}- \\
(0.17)\end{array}$ \\
\hline $25-34$ & $\begin{array}{l}0.19 \\
(0.32)\end{array}$ & $\begin{array}{l}0.22 \\
(0.36)\end{array}$ & $\begin{array}{l}0.38 \\
(0.00)\end{array}$ & $\begin{array}{l}0.22 \\
(0.29)\end{array}$ & $\begin{array}{l}0.30 \\
(0.31)\end{array}$ & $\begin{array}{l}0.21 \\
(0.34)\end{array}$ & $\begin{array}{l}0.36 \\
(0.38)\end{array}$ & $\begin{array}{l}0.21 \\
(0.32)\end{array}$ & $\begin{array}{l}0.33 \\
(0.32)\end{array}$ & $\begin{array}{l}0.16 \\
(0.27)\end{array}$ & $\begin{array}{l}0.33 \\
(0.30)\end{array}$ & $\begin{array}{l}0.22 \\
(0.26)\end{array}$ \\
\hline $35-54$ & $\begin{array}{l}0.35 \\
(0.47)\end{array}$ & $\begin{array}{l}0.45 \\
(0.51)\end{array}$ & $\begin{array}{l}0.52 \\
(0.00)\end{array}$ & $\begin{array}{l}0.33 \\
(0.43)\end{array}$ & $\begin{array}{l}0.59 \\
(0.53)\end{array}$ & $\begin{array}{l}0.48 \\
(0.48)\end{array}$ & $\begin{array}{l}0.58 \\
(0.36)\end{array}$ & $\begin{array}{l}0.48 \\
(0.53)\end{array}$ & $\begin{array}{l}0.62 \\
(0.50)\end{array}$ & $\begin{array}{l}0.33 \\
(0.54)\end{array}$ & $\begin{array}{l}0.40 \\
(0.44)\end{array}$ & $\begin{array}{l}0.35 \\
(0.46)\end{array}$ \\
\hline 55 and over & $\begin{array}{l}0.26 \\
(0.05)\end{array}$ & $\begin{array}{l}0.54 \\
(0.04)\end{array}$ & $\begin{array}{l}0.49 \\
(0.00)\end{array}$ & $\begin{array}{l}0.32 \\
(0.08)\end{array}$ & $\begin{array}{l}0.77 \\
(0.03)\end{array}$ & $\begin{array}{l}0.53 \\
(0.07)\end{array}$ & $\begin{array}{l}0.65 \\
(0.04)\end{array}$ & $\begin{array}{l}0.45 \\
(0.05)\end{array}$ & $\begin{array}{l}0.71 \\
(0.09)\end{array}$ & $\begin{array}{l}0.37 \\
(0.11)\end{array}$ & $\begin{array}{l}0.28 \\
(0.11)\end{array}$ & $\begin{array}{l}0.34 \\
(0.10)\end{array}$ \\
\hline \multicolumn{13}{|c|}{ Education } \\
\hline $\begin{array}{l}\text { Early childhood, primary } \\
\text { and lower secondary }\end{array}$ & $\begin{array}{l}- \\
(0.32)\end{array}$ & $\begin{array}{l}- \\
(0.34)\end{array}$ & $\begin{array}{c}- \\
\text { n.a. }\end{array}$ & $\begin{array}{l}- \\
(0.32)\end{array}$ & $\begin{array}{l}- \\
(0.15)\end{array}$ & $\begin{array}{l}- \\
(0.42)\end{array}$ & $\begin{array}{l}- \\
(0.26)\end{array}$ & $\begin{array}{l}- \\
(0.65)\end{array}$ & $\begin{array}{l}- \\
(0.61)\end{array}$ & $\begin{array}{l}- \\
(0.70)\end{array}$ & $\begin{array}{l}- \\
(0.55)\end{array}$ & $\begin{array}{l}- \\
(0.14)\end{array}$ \\
\hline Upper secondary & $\begin{array}{l}0.23 \\
(0.66)\end{array}$ & $\begin{array}{l}0.12 \\
(0.43)\end{array}$ & $\begin{array}{l}0.16 \\
\text { n.a. }\end{array}$ & $\begin{array}{l}0.10 \\
(0.50)\end{array}$ & $\begin{array}{l}0.06 \\
(0.60)\end{array}$ & $\begin{array}{l}0.08 \\
(0.46)\end{array}$ & $\begin{array}{l}0.18 \\
(0.54)\end{array}$ & $\begin{array}{l}0.19 \\
(0.29)\end{array}$ & $\begin{array}{l}0.23 \\
(0.19)\end{array}$ & $\begin{array}{l}0.09 \\
(0.15)\end{array}$ & $\begin{array}{l}0.10 \\
(0.30)\end{array}$ & $\begin{array}{l}0.23 \\
(0.57)\end{array}$ \\
\hline Non-university tertiary & $\begin{array}{l}\text { n.s. } \\
(0.00)\end{array}$ & $\begin{array}{l}0.28 \\
(0.14)\end{array}$ & $\begin{array}{l}0.22 \\
\text { n.a. }\end{array}$ & $\begin{array}{l}0.20 \\
(0.05)\end{array}$ & $\begin{array}{l}0.26 \\
(0.13)\end{array}$ & $\begin{array}{l}0.18 \\
(0.03)\end{array}$ & $\begin{array}{l}0.35 \\
(0.14)\end{array}$ & $\begin{array}{l}\text { n.s. } \\
(0.00)\end{array}$ & $\begin{array}{l}0.21 \\
(0.09)\end{array}$ & $\begin{array}{l}0.15 \\
(0.09)\end{array}$ & $\begin{array}{l}0.25 \\
(0.06)\end{array}$ & $\begin{array}{l}0.31 \\
(0.08)\end{array}$ \\
\hline University tertiary & $\begin{array}{l}0.49 \\
(0.02)\end{array}$ & $\begin{array}{l}0.44 \\
(0.09)\end{array}$ & $\begin{array}{l}0.42 \\
\text { n.a. }\end{array}$ & $\begin{array}{l}0.22 \\
(0.14)\end{array}$ & $\begin{array}{l}0.62 \\
(0.12)\end{array}$ & $\begin{array}{l}0.34 \\
(0.09)\end{array}$ & $\begin{array}{l}0.56 \\
(0.07)\end{array}$ & $\begin{array}{l}0.21 \\
(0.06)\end{array}$ & $\begin{array}{l}0.45 \\
(0.11)\end{array}$ & $\begin{array}{l}0.32 \\
(0.06)\end{array}$ & $\begin{array}{l}0.40 \\
(0.09)\end{array}$ & $\begin{array}{l}0.44 \\
(0.22)\end{array}$ \\
\hline R-squared & 0.75 & 0.91 & 0.96 & 0.93 & 0.90 & 0.93 & 0.92 & 0.88 & 0.96 & 0.90 & 0.95 & 0.97 \\
\hline R-squared adjusted & 0.67 & 0.88 & 0.95 & 0.92 & 0.87 & 0.90 & 0.89 & 0.85 & 0.95 & 0.87 & 0.94 & 0.96 \\
\hline \multicolumn{13}{|c|}{$\begin{array}{l}\text { Note: } \\
\text { The dependent variable is the fixed effect obtained in the first-stage regression for each age } x \text { education } x \text { gender category. These equations are } \\
\text { thus estimated with } 32 \text { observations for each country. }\end{array}$} \\
\hline
\end{tabular}

135. Table A3.6 shows the estimates of wage premia obtained in first-step regressions. Wage premia are the estimates of the industry fixed effects in country-by-country regressions of hourly earnings of full- 
time workers in 41 manufacturing and non-manufacturing industries on the above observable worker characteristics (see Jean and Nicoletti, 2001). The wage premia shown in the Table are centered with respect to each country's mean wage premia.

\subsection{Employment}

136. Table A3.7 shows the results of employment regressions when product market regulation is proxied by the economy-wide indicators of regulation for $1998 .{ }^{104}$ The economy-wide indicators lack the time dimension but contain more regulatory detail and cover a wider set of industries than the industryspecific indicators used to proxy regulatory developments over time in the regressions shown in Table 13. Since these indicators are timeless, the impact of regulation on employment is estimated by means of a random-effects GLS estimator and a two-step approach, in which the country fixed effects from a first-step regression omitting product market regulation are regressed on the summary indicators of regulation. ${ }^{105}$

137. These regressions are affected by the high correlation existing between the stringency of EPL and product market regulations across countries, which generates a multicollinearity problem. In the two-stage approach the country-specific effects are already purged of the effects of labour market policies and institutions on employment rates, and thus their possible correlation with PM regulations should reflect additional effects of these regulations on employment. However, this approach does not solve completely the problem of multicollinearity between the product market and EPL indicators, since the first stage estimates of the EPL coefficient may partially reflect the effects of the omitted product market regulation variables, affecting the estimates of the country-specific fixed effects as well as their correlation with the product market indicators.

138. The random-effect model in Panel A considers either the summary indicator of regulation or the three sub-components (state control, barriers to entrepreneurship and barriers to trade). The coefficients on most of these product market indicators are negatively signed (with the exception of barriers to entrepreneuship). ${ }^{106}$ The results from the two-stage approach are qualitatively similar to those obtained in the random effects specification: the overall indicator of product market regulation is negatively signed but not statistically significant, while the index of state control is negative and marginally significant but is accompanied by a positively-signed coefficient on barriers to entrepreneurship, which is difficult to interpret. The marginal significance of product market regulations in the two regressions may simply be a reflection of an upward bias in the coefficient of EPL due to an omitted variable (or omitted time dimension) problem.

104. These indicators are described in detail in Nicoletti et al. (1999). Model specification and regression results are discussed in detail in Nicoletti and Scarpetta (2001).

105. The second step uses a weighted cross-section regression, where the fixed effects estimated in the first step are weighted by the inverse of their standard errors to account for sampling error.

106. These estimates suffer from a possible misspecification as indicated by the Hausman test. 
ECO/WKP(2001)38

Table A3.6. Estimated sectoral wage premia in selected OECD countries ${ }^{1}$ Results of first-step regressions

\begin{tabular}{|c|c|c|c|c|c|c|c|c|c|c|c|c|}
\hline & Austria & Belgium & Canada & Denmark & France & Greece & Ireland & Italy & Spain & Sweden & $\begin{array}{c}\text { United } \\
\text { Kingdom }\end{array}$ & $\begin{array}{l}\text { United } \\
\text { States }\end{array}$ \\
\hline \multicolumn{13}{|l|}{ Manufacturing } \\
\hline Food \& Beverages & $\begin{array}{r}-0.02 \\
\quad(0.03)\end{array}$ & $\begin{array}{r}-0.03 \\
\quad(0.03)\end{array}$ & $\begin{array}{r}-0.01 \\
\quad(0.02)\end{array}$ & $\begin{array}{l}-0.06 \\
\quad(0.02)\end{array}$ & $\begin{array}{l}-0.04 \\
\quad(0.06)\end{array}$ & $\begin{array}{l}0.02 \\
\quad(0.03)\end{array}$ & $\begin{array}{l}0.02 \\
\quad(0.03)\end{array}$ & $\begin{array}{l}0.05 \\
(0.04)\end{array}$ & $\begin{array}{l}0.00 \\
(0.03)\end{array}$ & $\begin{array}{l}-0.01 \\
\quad(0.02)\end{array}$ & $\begin{array}{r}-0.06 \\
\quad(0.03)\end{array}$ & $\begin{array}{l}-0.07 \\
\quad(0.05)\end{array}$ \\
\hline Tobacco & $\begin{array}{l}0.25 \\
(0.04)\end{array}$ & $\begin{array}{l}0.12 \\
\quad(0.04)\end{array}$ & & $\begin{array}{r}-0.06 \\
(0.03)\end{array}$ & & $\begin{array}{l}0.27 \\
(0.03)\end{array}$ & $\begin{array}{l}0.26 \\
\quad(0.09)\end{array}$ & $\begin{array}{l}-0.13 \\
\quad(0.05)\end{array}$ & $\begin{array}{l}0.26 \\
(0.04)\end{array}$ & $\begin{array}{l}-0.07 \\
\quad(0.04)\end{array}$ & $\begin{array}{l}0.35 \\
(0.10)\end{array}$ & $\begin{array}{l}0.26 \\
\quad(0.12)\end{array}$ \\
\hline Textiles & $\begin{array}{r}-0.06 \\
\quad(0.03)\end{array}$ & $\begin{array}{r}-0.13 \\
\quad(0.03)\end{array}$ & & $\begin{array}{r}-0.13 \\
(0.02)\end{array}$ & $\begin{array}{r}-0.20 \\
\quad(0.08)\end{array}$ & $\begin{array}{r}-0.02 \\
\quad(0.02)\end{array}$ & $\begin{array}{l}-0.15 \\
(0.03)\end{array}$ & $\begin{array}{l}-0.13 \\
\quad(0.06)\end{array}$ & $\begin{array}{l}-0.13 \\
\quad(0.03)\end{array}$ & & $\begin{array}{r}-0.26 \\
(0.04)\end{array}$ & $\begin{array}{l}-0.09 \\
\quad(0.07)\end{array}$ \\
\hline Wearing apparel & $\begin{array}{l}-0.21 \\
\quad(0.05)\end{array}$ & $\begin{array}{r}-0.09 \\
\quad(0.03)\end{array}$ & & $\begin{array}{r}-0.14 \\
(0.03)\end{array}$ & $\begin{array}{r}-0.28 \\
\quad(0.07)\end{array}$ & $\begin{array}{l}-0.15 \\
\quad(0.03)\end{array}$ & $\begin{array}{l}-0.17 \\
\quad(0.04)\end{array}$ & $\begin{array}{r}-0.23 \\
\quad(0.05)\end{array}$ & $\begin{array}{l}-0.17 \\
\quad(0.03)\end{array}$ & $\begin{array}{l}-0.19 \\
\quad(0.02)\end{array}$ & $\begin{array}{r}-0.26 \\
(0.04)\end{array}$ & $\begin{array}{r}-0.21 \\
\quad(0.06)\end{array}$ \\
\hline Leather & $\begin{array}{r}-0.20 \\
\quad(0.03)\end{array}$ & $\begin{array}{r}-0.10 \\
\quad(0.03)\end{array}$ & & $\begin{array}{r}-0.15 \\
(0.03)\end{array}$ & $\begin{array}{r}-0.34 \\
\quad(0.10)\end{array}$ & $\begin{array}{r}-0.09 \\
\quad(0.03)\end{array}$ & $\begin{array}{l}-0.30 \\
(0.04)\end{array}$ & $\begin{array}{r}-0.24 \\
(0.07)\end{array}$ & $\begin{array}{l}-0.17 \\
\quad(0.03)\end{array}$ & $\begin{array}{r}-0.09 \\
(0.02)\end{array}$ & $\begin{array}{r}-0.21 \\
(0.05)\end{array}$ & $\begin{array}{l}-0.15 \\
\quad(0.07)\end{array}$ \\
\hline Wood & $\begin{array}{l}-0.12 \\
\quad(0.03)\end{array}$ & $\begin{array}{r}-0.13 \\
(0.03)\end{array}$ & & $\begin{array}{r}-0.10 \\
(0.02)\end{array}$ & $\begin{array}{l}0.38 \\
(0.05)\end{array}$ & $\begin{array}{l}-0.02 \\
(0.04)\end{array}$ & $\begin{array}{r}-0.19 \\
(0.03)\end{array}$ & $\begin{array}{r}-0.18 \\
(0.05)\end{array}$ & $\begin{array}{l}-0.20 \\
\quad(0.02)\end{array}$ & $\begin{array}{r}-0.06 \\
(0.03)\end{array}$ & $\begin{array}{r}-0.15 \\
(0.04)\end{array}$ & $\begin{array}{l}-0.08 \\
(0.05)\end{array}$ \\
\hline Pulp \& Paper & $\begin{array}{l}0.00 \\
(0.03)\end{array}$ & $\begin{array}{l}0.03 \\
\quad(0.03)\end{array}$ & & $\begin{array}{r}-0.02 \\
\quad(0.02)\end{array}$ & $\begin{array}{l}0.05 \\
\quad(0.06)\end{array}$ & $\begin{array}{l}0.06 \\
(0.03)\end{array}$ & $\begin{array}{l}0.04 \\
\quad(0.02)\end{array}$ & $\begin{array}{l}-0.01 \\
\quad(0.06)\end{array}$ & $\begin{array}{l}0.08 \\
(0.03)\end{array}$ & $\begin{array}{l}0.07 \\
(0.03)\end{array}$ & $\begin{array}{l}0.00 \\
(0.04)\end{array}$ & $\begin{array}{l}0.08 \\
(0.05)\end{array}$ \\
\hline Printing \& Publishing & $\begin{array}{l}0.13 \\
(0.04)\end{array}$ & $\begin{array}{l}0.02 \\
(0.02)\end{array}$ & & $\begin{array}{l}0.12 \\
\quad(0.02)\end{array}$ & $\begin{array}{l}0.04 \\
(0.08)\end{array}$ & $\begin{array}{l}0.03 \\
(0.03)\end{array}$ & $\begin{array}{l}0.15 \\
(0.03)\end{array}$ & $\begin{array}{l}0.08 \\
(0.05)\end{array}$ & $\begin{array}{l}0.07 \\
(0.03)\end{array}$ & $\begin{array}{l}0.03 \\
(0.02)\end{array}$ & $\begin{array}{l}0.17 \\
(0.03)\end{array}$ & $\begin{array}{l}-0.03 \\
\quad(0.06)\end{array}$ \\
\hline Coke, Petroleum products & $\begin{array}{l}0.45 \\
\quad(0.05)\end{array}$ & $\begin{array}{l}0.20 \\
(0.04)\end{array}$ & & $\begin{array}{l}0.15 \\
(0.02)\end{array}$ & $\begin{array}{l}0.25 \\
(0.05)\end{array}$ & $\begin{array}{l}0.39 \\
(0.05)\end{array}$ & & $\begin{array}{l}0.20 \\
(0.04)\end{array}$ & $\begin{array}{l}0.43 \\
(0.03)\end{array}$ & $\begin{array}{l}0.11 \\
(0.03)\end{array}$ & $\begin{array}{l}0.23 \\
(0.04)\end{array}$ & $\begin{array}{l}0.19 \\
\quad(0.07)\end{array}$ \\
\hline Chemicals & $\begin{array}{l}0.11 \\
\quad(0.03)\end{array}$ & $\begin{array}{l}0.13 \\
\quad(0.02)\end{array}$ & & $\begin{array}{l}0.06 \\
(0.02)\end{array}$ & $\begin{array}{l}0.13 \\
\quad(0.05)\end{array}$ & $\begin{array}{l}0.15 \\
\quad(0.03)\end{array}$ & $\begin{array}{l}0.11 \\
\quad(0.02)\end{array}$ & $\begin{array}{l}0.09 \\
(0.04)\end{array}$ & $\begin{array}{l}0.12 \\
\quad(0.02)\end{array}$ & $\begin{array}{l}0.08 \\
(0.04)\end{array}$ & $\begin{array}{l}0.11 \\
\quad(0.02)\end{array}$ & $\begin{array}{l}0.10 \\
(0.05)\end{array}$ \\
\hline Rubber \& Plastics products & $\begin{array}{l}0.02 \\
\quad(0.03)\end{array}$ & $\begin{array}{l}0.02 \\
\quad(0.02)\end{array}$ & & $\begin{array}{l}-0.05 \\
\quad(0.01)\end{array}$ & $\begin{array}{l}-0.09 \\
\quad(0.05)\end{array}$ & $\begin{array}{r}-0.04 \\
\quad(0.03)\end{array}$ & & $\begin{array}{l}-0.06 \\
\quad(0.05)\end{array}$ & $\begin{array}{l}0.03 \\
(0.03)\end{array}$ & $\begin{array}{l}0.01 \\
\quad(0.02)\end{array}$ & $\begin{array}{r}-0.10 \\
(0.03)\end{array}$ & $\begin{array}{l}-0.02 \\
\quad(0.05)\end{array}$ \\
\hline Non-metallic mineral products & $\begin{array}{l}0.07 \\
\quad(0.03)\end{array}$ & $\begin{array}{r}-0.01 \\
\quad(0.02)\end{array}$ & & $\begin{array}{l}-0.04 \\
\quad(0.02)\end{array}$ & $\begin{array}{l}0.00 \\
(0.05)\end{array}$ & $\begin{array}{l}0.05 \\
(0.02)\end{array}$ & $\begin{array}{l}-0.03 \\
\quad(0.03)\end{array}$ & $\begin{array}{r}-0.06 \\
\quad(0.05)\end{array}$ & $\begin{array}{l}0.04 \\
(0.02)\end{array}$ & $\begin{array}{l}0.01 \\
(0.05)\end{array}$ & $\begin{array}{r}-0.12 \\
(0.03)\end{array}$ & $\begin{array}{r}-0.01 \\
\quad(0.06)\end{array}$ \\
\hline Basic metals & $\begin{array}{l}0.07 \\
\quad(0.03)\end{array}$ & $\begin{array}{l}0.08 \\
\quad(0.02)\end{array}$ & & $\begin{array}{r}-0.07 \\
\quad(0.02)\end{array}$ & $\begin{array}{r}-0.01 \\
\quad(0.07)\end{array}$ & $\begin{array}{l}0.09 \\
(0.03)\end{array}$ & $\begin{array}{l}0.13 \\
(0.03)\end{array}$ & $\begin{array}{l}-0.03 \\
\quad(0.06)\end{array}$ & $\begin{array}{l}0.14 \\
(0.03)\end{array}$ & $\begin{array}{l}0.07 \\
(0.03)\end{array}$ & $\begin{array}{r}-0.07 \\
\quad(0.04)\end{array}$ & $\begin{array}{l}0.10 \\
(0.06)\end{array}$ \\
\hline Fabricated metal product & $\begin{array}{l}0.01 \\
\quad(0.03)\end{array}$ & $\begin{array}{r}-0.08 \\
\quad(0.02)\end{array}$ & & $\begin{array}{r}-0.09 \\
\quad(0.02)\end{array}$ & $\begin{array}{l}-0.04 \\
\quad(0.05)\end{array}$ & $\begin{array}{l}-0.03 \\
\quad(0.03)\end{array}$ & $\begin{array}{l}-0.09 \\
\quad(0.02)\end{array}$ & $\begin{array}{l}-0.09 \\
\quad(0.05)\end{array}$ & $\begin{array}{l}0.04 \\
(0.02)\end{array}$ & $\begin{array}{l}-0.05 \\
\quad(0.03)\end{array}$ & $\begin{array}{l}-0.07 \\
\quad(0.03)\end{array}$ & $\begin{array}{l}-0.02 \\
\quad(0.05)\end{array}$ \\
\hline Machinery and equipment n.e.c & $\begin{array}{l}0.06 \\
(0.04)\end{array}$ & $\begin{array}{r}-0.07 \\
\quad(0.02)\end{array}$ & & $\begin{array}{r}-0.08 \\
\quad(0.02)\end{array}$ & $\begin{array}{l}0.00 \\
(0.06)\end{array}$ & $\begin{array}{l}0.07 \\
(0.03)\end{array}$ & $\begin{array}{l}-0.06 \\
\quad(0.02)\end{array}$ & $\begin{array}{l}-0.05 \\
\quad(0.04)\end{array}$ & $\begin{array}{l}0.11 \\
(0.03)\end{array}$ & $\begin{array}{l}-0.05 \\
(0.02)\end{array}$ & $\begin{array}{r}-0.02 \\
(0.03)\end{array}$ & $\begin{array}{l}0.08 \\
(0.05)\end{array}$ \\
\hline Office machinery & $\begin{array}{l}0.15 \\
(0.05)\end{array}$ & $\begin{array}{r}-0.09 \\
\quad(0.04)\end{array}$ & & $\begin{array}{l}-0.04 \\
\quad(0.02)\end{array}$ & $\begin{array}{l}0.08 \\
(0.13)\end{array}$ & & $\begin{array}{l}0.00 \\
\quad(0.03)\end{array}$ & $\begin{array}{l}0.11 \\
\quad(0.05)\end{array}$ & $\begin{array}{l}0.16 \\
\quad(0.05)\end{array}$ & $\begin{array}{l}0.03 \\
\quad(0.05)\end{array}$ & $\begin{array}{l}0.21 \\
\quad(0.04)\end{array}$ & $\begin{array}{l}0.09 \\
\quad(0.06)\end{array}$ \\
\hline Electrical machinery n.e.c & $\begin{array}{l}0.15 \\
(0.04)\end{array}$ & $\begin{array}{r}-0.02 \\
\quad(0.02)\end{array}$ & & $\begin{array}{r}-0.11 \\
\quad(0.02)\end{array}$ & $\begin{array}{l}-0.04 \\
\quad(0.06)\end{array}$ & $\begin{array}{l}0.03 \\
(0.03)\end{array}$ & $\begin{array}{r}-0.02 \\
(0.03)\end{array}$ & $\begin{array}{l}-0.05 \\
\quad(0.04)\end{array}$ & $\begin{array}{l}0.07 \\
(0.02)\end{array}$ & $\begin{array}{l}-0.05 \\
\quad(0.04)\end{array}$ & $\begin{array}{l}-0.07 \\
\quad(0.03)\end{array}$ & $\begin{array}{l}0.06 \\
(0.05)\end{array}$ \\
\hline Radio, television & $\begin{array}{l}0.13 \\
\quad(0.03)\end{array}$ & $\begin{array}{l}0.12 \\
\quad(0.03)\end{array}$ & & $\begin{array}{r}-0.12 \\
\quad(0.02)\end{array}$ & $\begin{array}{l}-0.01 \\
\quad(0.06)\end{array}$ & $\begin{array}{l}0.05 \\
(0.05)\end{array}$ & $\begin{array}{l}0.00 \\
(0.03)\end{array}$ & $\begin{array}{l}0.01 \\
(0.05)\end{array}$ & $\begin{array}{l}0.09 \\
(0.03)\end{array}$ & $\begin{array}{l}0.03 \\
(0.03)\end{array}$ & $\begin{array}{r}-0.01 \\
\quad(0.03)\end{array}$ & $\begin{array}{l}0.14 \\
(0.06)\end{array}$ \\
\hline Instruments, Watches, Clocks & $\begin{array}{l}0.07 \\
(0.03)\end{array}$ & $\begin{array}{r}-0.01 \\
\quad(0.02)\end{array}$ & & $\begin{array}{l}0.00 \\
(0.02)\end{array}$ & $\begin{array}{l}0.03 \\
(0.07)\end{array}$ & $\begin{array}{r}-0.09 \\
\quad(0.03)\end{array}$ & $\begin{array}{r}-0.01 \\
\quad(0.02)\end{array}$ & $\begin{array}{r}-0.05 \\
\quad(0.05)\end{array}$ & $\begin{array}{l}-0.03 \\
\quad(0.03)\end{array}$ & $\begin{array}{l}-0.01 \\
\quad(0.03)\end{array}$ & $\begin{array}{l}-0.03 \\
\quad(0.03)\end{array}$ & $\begin{array}{l}0.11 \\
\quad(0.05)\end{array}$ \\
\hline Motor vehicles & $\begin{array}{l}0.04 \\
\quad(0.03)\end{array}$ & $\begin{array}{l}0.08 \\
\quad(0.02)\end{array}$ & & $\begin{array}{r}-0.15 \\
\quad(0.02)\end{array}$ & $\begin{array}{l}-0.14 \\
\quad(0.05)\end{array}$ & $\begin{array}{l}0.03 \\
\quad(0.05)\end{array}$ & $\begin{array}{l}-0.13 \\
\quad(0.04)\end{array}$ & $\begin{array}{r}-0.12 \\
\quad(0.05)\end{array}$ & $\begin{array}{l}0.15 \\
\quad(0.03)\end{array}$ & $\begin{array}{l}0.03 \\
\quad(0.03)\end{array}$ & $\begin{array}{l}0.05 \\
\quad(0.04)\end{array}$ & $\begin{array}{l}0.20 \\
\quad(0.06)\end{array}$ \\
\hline Other transport equipment n.e.c & $\begin{array}{l}0.01 \\
\quad(0.03)\end{array}$ & $\begin{array}{l}0.06 \\
\quad(0.03)\end{array}$ & & $\begin{array}{l}-0.07 \\
\quad(0.02) \\
\end{array}$ & $\begin{array}{l}0.07 \\
\quad(0.06)\end{array}$ & $\begin{array}{l}0.28 \\
\quad(0.03)\end{array}$ & $\begin{array}{l}-0.02 \\
\quad(0.05)\end{array}$ & $\begin{array}{l}0.00 \\
(0.06)\end{array}$ & $\begin{array}{l}0.14 \\
(0.03) \\
\end{array}$ & $\begin{array}{l}0.00 \\
(0.04)\end{array}$ & $\begin{array}{l}0.05 \\
\quad(0.03)\end{array}$ & $\begin{array}{l}0.21 \\
\quad(0.05)\end{array}$ \\
\hline
\end{tabular}

1. In logarithm, compared to the economywide, employment weighted, average wage. 
ECO/WKP(2001)38

Table A3.6. Estimated sectoral wage premia in selected OECD countries ${ }^{1}$ (continued) Results of first-step regressions

\begin{tabular}{|c|c|c|c|c|c|c|c|c|c|c|c|c|}
\hline & Austria & Belgium & Canada & Denmark & France & Greece & Ireland & Italy & Spain & Sweden & $\begin{array}{c}\text { United } \\
\text { Kingdom }\end{array}$ & $\begin{array}{l}\text { United } \\
\text { States }\end{array}$ \\
\hline \multicolumn{13}{|l|}{ Non-manufacturing } \\
\hline Electricity, Gas and Water supply & $\begin{array}{l}0.17 \\
(0.03)\end{array}$ & $\begin{array}{l}0.25 \\
(0.03)\end{array}$ & $\begin{array}{l}0.27 \\
(0.03)\end{array}$ & $\begin{array}{l}0.01 \\
\quad(0.02)\end{array}$ & $\begin{array}{l}0.02 \\
(0.05)\end{array}$ & $\begin{array}{l}0.09 \\
(0.04)\end{array}$ & & $\begin{array}{l}0.18 \\
(0.04)\end{array}$ & $\begin{array}{l}0.27 \\
(0.04)\end{array}$ & $\begin{array}{l}0.07 \\
(0.03)\end{array}$ & $\begin{array}{l}0.21 \\
(0.03)\end{array}$ & $\begin{array}{l}0.28 \\
\quad(0.05)\end{array}$ \\
\hline Collection, distribution of water & $\begin{array}{r}-0.05 \\
(0.04)\end{array}$ & $\begin{array}{l}-0.03 \\
(0.03)\end{array}$ & & & $\begin{array}{l}0.17 \\
(0.05)\end{array}$ & $\begin{array}{l}0.19 \\
(0.03)\end{array}$ & & $\begin{array}{l}0.17 \\
\quad(0.07)\end{array}$ & $\begin{array}{l}0.07 \\
(0.03)\end{array}$ & & $\begin{array}{l}0.10 \\
(0.03)\end{array}$ & $\begin{array}{l}0.13 \\
(0.07)\end{array}$ \\
\hline Construction & $\begin{array}{l}0.01 \\
(0.04)\end{array}$ & $\begin{array}{l}-0.06 \\
(0.03)\end{array}$ & $\begin{array}{l}0.05 \\
(0.02)\end{array}$ & $\begin{array}{l}-0.01 \\
\quad(0.02)\end{array}$ & $\begin{array}{l}0.00 \\
(0.06)\end{array}$ & & & $\begin{array}{l}0.00 \\
(0.05)\end{array}$ & $\begin{array}{l}-0.04 \\
\quad(0.02)\end{array}$ & $\begin{array}{l}-0.01 \\
\quad(0.02)\end{array}$ & $\begin{array}{l}-0.03 \\
(0.02)\end{array}$ & $\begin{array}{l}0.13 \\
(0.05)\end{array}$ \\
\hline Sale, repair of motor vehicles & $\begin{array}{c}-0.07 \\
(0.04)\end{array}$ & $\begin{array}{c}-0.06 \\
(0.02)\end{array}$ & & $\begin{array}{c}-0.07 \\
(0.02)\end{array}$ & $\begin{array}{c}-0.06 \\
(0.05)\end{array}$ & $\begin{array}{l}-0.03 \\
(0.03)\end{array}$ & $\begin{array}{r}-0.12 \\
(0.03)\end{array}$ & $\begin{array}{c}-0.10 \\
(0.05)\end{array}$ & $\begin{array}{c}-0.12 \\
(0.03)\end{array}$ & $\begin{array}{c}-0.04 \\
(0.02)\end{array}$ & $\begin{array}{c}-0.14 \\
(0.03)\end{array}$ & $\begin{array}{c}-0.13 \\
(0.06)\end{array}$ \\
\hline Wholesale trade & $\begin{array}{l}0.03 \\
(0.03)\end{array}$ & $\begin{array}{r}-0.01 \\
(0.02)\end{array}$ & $\begin{array}{l}-0.03 \\
(0.02)\end{array}$ & $\begin{array}{l}0.03 \\
(0.02)\end{array}$ & $\begin{array}{l}0.09 \\
(0.06)\end{array}$ & $\begin{array}{r}-0.05 \\
(0.02)\end{array}$ & $\begin{array}{l}0.08 \\
(0.03)\end{array}$ & $\begin{array}{l}0.01 \\
(0.05)\end{array}$ & $\begin{array}{r}-0.09 \\
(0.02)\end{array}$ & $\begin{array}{l}0.04 \\
(0.03)\end{array}$ & $\begin{array}{r}-0.02 \\
(0.02)\end{array}$ & $\begin{array}{l}-0.07 \\
\quad(0.05)\end{array}$ \\
\hline Retail trade & $\begin{array}{c}-0.05 \\
(0.04)\end{array}$ & $\begin{array}{c}-0.15 \\
(0.02)\end{array}$ & $\begin{array}{l}-0.17 \\
(0.02)\end{array}$ & $\begin{array}{c}-0.10 \\
(0.02)\end{array}$ & $\begin{array}{c}-0.08 \\
(0.05)\end{array}$ & $\begin{array}{r}-0.15 \\
(0.03)\end{array}$ & $\begin{array}{r}-0.22 \\
(0.03)\end{array}$ & $\begin{array}{l}-0.07 \\
(0.05)\end{array}$ & $\begin{array}{c}-0.12 \\
\quad(0.03)\end{array}$ & $\begin{array}{c}-0.04 \\
(0.02)\end{array}$ & $\begin{array}{r}-0.11 \\
(0.03)\end{array}$ & $\begin{array}{r}-0.18 \\
(0.05)\end{array}$ \\
\hline Hotels \& Restaurants & $\begin{array}{l}-0.30 \\
(0.05)\end{array}$ & $\begin{array}{r}-0.21 \\
(0.03)\end{array}$ & $\begin{array}{l}-0.35 \\
(0.02)\end{array}$ & $\begin{array}{r}-0.08 \\
(0.02)\end{array}$ & $\begin{array}{l}-0.19 \\
(0.09)\end{array}$ & $\begin{array}{r}-0.03 \\
(0.03)\end{array}$ & $\begin{array}{l}-0.23 \\
(0.02)\end{array}$ & $\begin{array}{l}-0.14 \\
(0.06)\end{array}$ & $\begin{array}{l}-0.15 \\
(0.03)\end{array}$ & $\begin{array}{r}-0.08 \\
(0.03)\end{array}$ & $\begin{array}{r}-0.30 \\
(0.04)\end{array}$ & $\begin{array}{l}-0.24 \\
\quad(0.05)\end{array}$ \\
\hline Land transport & $\begin{array}{r}-0.06 \\
(0.04)\end{array}$ & $\begin{array}{r}-0.08 \\
(0.03)\end{array}$ & $\begin{array}{l}-0.01 \\
(0.02)\end{array}$ & $\begin{array}{c}-0.14 \\
(0.03)\end{array}$ & $\begin{array}{l}-0.10 \\
(0.05)\end{array}$ & $\begin{array}{l}0.10 \\
(0.02)\end{array}$ & & $\begin{array}{l}0.15 \\
(0.06)\end{array}$ & $\begin{array}{r}-0.02 \\
(0.02)\end{array}$ & $\begin{array}{r}-0.08 \\
(0.04)\end{array}$ & $\begin{array}{c}-0.09 \\
(0.04)\end{array}$ & $\begin{array}{l}0.03 \\
(0.05)\end{array}$ \\
\hline Water transport & $\begin{array}{l}0.15 \\
(0.06)\end{array}$ & $\begin{array}{l}0.10 \\
(0.03)\end{array}$ & 0.00 & $\begin{array}{l}0.03 \\
(0.02)\end{array}$ & & $\begin{array}{l}0.23 \\
(0.04)\end{array}$ & & $\begin{array}{l}0.01 \\
(0.06)\end{array}$ & $\begin{array}{l}0.32 \\
(0.08)\end{array}$ & $\begin{array}{l}0.12 \\
(0.03)\end{array}$ & $\begin{array}{l}0.09 \\
(0.04)\end{array}$ & $\begin{array}{l}0.05 \\
(0.09)\end{array}$ \\
\hline Air transport & $\begin{array}{l}0.15 \\
(0.08)\end{array}$ & $\begin{array}{l}0.14 \\
\quad(0.05)\end{array}$ & & $\begin{array}{l}0.18 \\
(0.03)\end{array}$ & & $\begin{array}{l}0.12 \\
\quad(0.04)\end{array}$ & & $\begin{array}{l}0.32 \\
(0.05)\end{array}$ & $\begin{array}{l}0.03 \\
(0.06)\end{array}$ & $\begin{array}{l}0.14 \\
(0.06)\end{array}$ & $\begin{array}{l}0.22 \\
(0.03)\end{array}$ & $\begin{array}{l}0.11 \\
\quad(0.06)\end{array}$ \\
\hline Auxiliary transport activities & $\begin{array}{l}0.00 \\
(0.04)\end{array}$ & $\begin{array}{r}-0.01 \\
(0.02)\end{array}$ & & $\begin{array}{l}-0.01 \\
(0.02)\end{array}$ & $\begin{array}{l}-0.16 \\
(0.07)\end{array}$ & $\begin{array}{r}-0.11 \\
(0.02)\end{array}$ & & $\begin{array}{r}-0.01 \\
(0.04)\end{array}$ & $\begin{array}{l}0.00 \\
(0.03)\end{array}$ & $\begin{array}{r}-0.03 \\
(0.03)\end{array}$ & $\begin{array}{l}0.04 \\
(0.03)\end{array}$ & $\begin{array}{l}0.01 \\
(0.07)\end{array}$ \\
\hline Post \& Communications & $\begin{array}{l}0.02 \\
(0.05)\end{array}$ & $\begin{array}{l}0.09 \\
(0.04)\end{array}$ & $\begin{array}{l}0.11 \\
(0.02)\end{array}$ & $\begin{array}{l}0.08 \\
(0.03)\end{array}$ & & $\begin{array}{l}0.05 \\
(0.03)\end{array}$ & & $\begin{array}{l}0.06 \\
(0.05)\end{array}$ & $\begin{array}{l}0.13 \\
(0.05)\end{array}$ & $\begin{array}{l}0.00 \\
(0.03)\end{array}$ & $\begin{array}{l}0.10 \\
(0.03)\end{array}$ & $\begin{array}{l}0.14 \\
\quad(0.05)\end{array}$ \\
\hline Financial intermediation & $\begin{array}{l}0.17 \\
(0.04)\end{array}$ & $\begin{array}{l}0.15 \\
(0.03)\end{array}$ & $\begin{array}{l}0.10 \\
(0.03)\end{array}$ & $\begin{array}{l}0.15 \\
\quad(0.02)\end{array}$ & $\begin{array}{l}0.09 \\
(0.06)\end{array}$ & $\begin{array}{l}0.18 \\
(0.03)\end{array}$ & $\begin{array}{l}0.18 \\
\quad(0.04)\end{array}$ & $\begin{array}{l}0.28 \\
(0.05)\end{array}$ & $\begin{array}{l}0.18 \\
(0.04)\end{array}$ & $\begin{array}{l}0.08 \\
(0.05)\end{array}$ & $\begin{array}{l}0.29 \\
(0.03)\end{array}$ & $\begin{array}{l}0.02 \\
(0.05)\end{array}$ \\
\hline Insurance & $\begin{array}{l}0.11 \\
(0.04)\end{array}$ & $\begin{array}{l}0.08 \\
(0.03)\end{array}$ & $\begin{array}{l}0.14 \\
(0.00)\end{array}$ & $\begin{array}{l}0.21 \\
\quad(0.02)\end{array}$ & $\begin{array}{l}0.03 \\
(0.08)\end{array}$ & $\begin{array}{l}0.15 \\
(0.03)\end{array}$ & $\begin{array}{l}0.21 \\
(0.04)\end{array}$ & $\begin{array}{l}0.10 \\
(0.05)\end{array}$ & $\begin{array}{l}0.04 \\
(0.03)\end{array}$ & $\begin{array}{l}0.17 \\
(0.04)\end{array}$ & $\begin{array}{l}0.20 \\
(0.04)\end{array}$ & $\begin{array}{l}0.05 \\
(0.05)\end{array}$ \\
\hline Auxiliary financial activities & $\begin{array}{l}0.19 \\
(0.05)\end{array}$ & $\begin{array}{l}0.02 \\
(0.03)\end{array}$ & & $\begin{array}{l}0.31 \\
(0.04)\end{array}$ & $\begin{array}{l}0.19 \\
(0.07)\end{array}$ & $\begin{array}{l}0.20 \\
(0.07)\end{array}$ & & $\begin{array}{l}0.13 \\
(0.06)\end{array}$ & $\begin{array}{l}0.23 \\
(0.05)\end{array}$ & $\begin{array}{l}0.14 \\
(0.05)\end{array}$ & $\begin{array}{l}0.23 \\
(0.04)\end{array}$ & \\
\hline Real estate & $\begin{array}{l}0.07 \\
(0.04)\end{array}$ & $\begin{array}{r}-0.05 \\
(0.03)\end{array}$ & $\begin{array}{l}-0.09 \\
(0.04)\end{array}$ & $\begin{array}{r}-0.06 \\
(0.02)\end{array}$ & $\begin{array}{c}-0.05 \\
(0.20)\end{array}$ & & & $\begin{array}{l}0.09 \\
(0.09)\end{array}$ & $\begin{array}{l}0.04 \\
(0.04)\end{array}$ & $\begin{array}{r}-0.03 \\
(0.04)\end{array}$ & $\begin{array}{l}0.03 \\
(0.03)\end{array}$ & $\begin{array}{l}-0.03 \\
\quad(0.05)\end{array}$ \\
\hline Renting of machinery \& equipment & $\begin{array}{c}-0.04 \\
(0.03)\end{array}$ & $\begin{array}{l}-0.06 \\
(0.04)\end{array}$ & & $\begin{array}{l}-0.01 \\
(0.04)\end{array}$ & & & & & $\begin{array}{l}-0.12 \\
\quad(0.05)\end{array}$ & $\begin{array}{l}-0.02 \\
(0.04)\end{array}$ & $\begin{array}{l}-0.02 \\
(0.04)\end{array}$ & $\begin{array}{r}-0.17 \\
(0.06)\end{array}$ \\
\hline Computer & $\begin{array}{l}0.21 \\
(0.04)\end{array}$ & $\begin{array}{l}0.04 \\
(0.02)\end{array}$ & & $\begin{array}{l}0.20 \\
(0.02)\end{array}$ & $\begin{array}{l}0.28 \\
(0.14)\end{array}$ & & & $\begin{array}{l}0.06 \\
(0.05)\end{array}$ & $\begin{array}{l}0.03 \\
(0.05)\end{array}$ & $\begin{array}{l}0.12 \\
(0.04)\end{array}$ & $\begin{array}{l}0.24 \\
(0.04)\end{array}$ & $\begin{array}{l}0.18 \\
(0.06)\end{array}$ \\
\hline Research and development & $\begin{array}{l}0.08 \\
(0.06)\end{array}$ & $\begin{array}{l}0.03 \\
(0.03)\end{array}$ & & $\begin{array}{l}0.16 \\
(0.02)\end{array}$ & $\begin{array}{c}-0.01 \\
(0.06)\end{array}$ & & & $\begin{array}{l}0.06 \\
(0.05)\end{array}$ & & $\begin{array}{l}0.02 \\
(0.04)\end{array}$ & $\begin{array}{l}0.17 \\
(0.04)\end{array}$ & $\begin{array}{l}0.14 \\
\quad(0.06)\end{array}$ \\
\hline Other business services & $\begin{array}{c}-0.02 \\
(0.03)\end{array}$ & $\begin{array}{c}-0.02 \\
(0.02) \\
\end{array}$ & $\begin{array}{c}-0.01 \\
(0.02) \\
\end{array}$ & $\begin{array}{l}0.01 \\
(0.02)\end{array}$ & $\begin{array}{l}0.08 \\
(0.06)\end{array}$ & & & $\begin{array}{c}-0.07 \\
(0.04) \\
\end{array}$ & $\begin{array}{c}-0.04 \\
(0.02) \\
\end{array}$ & $\begin{array}{l}0.01 \\
(0.02) \\
\end{array}$ & $\begin{array}{l}0.10 \\
(0.03)\end{array}$ & $\begin{array}{r}-0.01 \\
(0.05) \\
\end{array}$ \\
\hline Adjus & 0.13 & 0.09 & 0.16 & 0.11 & 0.13 & 0.12 & 0.14 & 0.12 & 0.14 & 0.07 & 0.15 & 0.11 \\
\hline Correlation with US structure & 0.72 & 0.75 & 0.90 & 0.35 & 0.48 & 0.70 & 0.62 & 0.49 & 0.78 & 0.61 & 0.72 & 1.00 \\
\hline R-sque & 0.87 & 0.91 & 0.94 & 0.85 & 0.88 & 0.88 & 0.93 & 0.78 & 0.88 & 0.84 & 0.84 & 0.67 \\
\hline Observations & 676 & 905 & 337 & 1128 & 310 & 677 & 431 & 733 & 1021 & 398 & 1023 & 1311 \\
\hline
\end{tabular}

1. In logarithm, compared to the economywide, employment weighted, average wage.

Source : Jean and Nicoletti (2001). 
ECO/WKP(2001)38

Table A3.7. Labour and product market determinants of the non-agricultural employment rate, 1982-1998 : Results with static economy-wide regulation

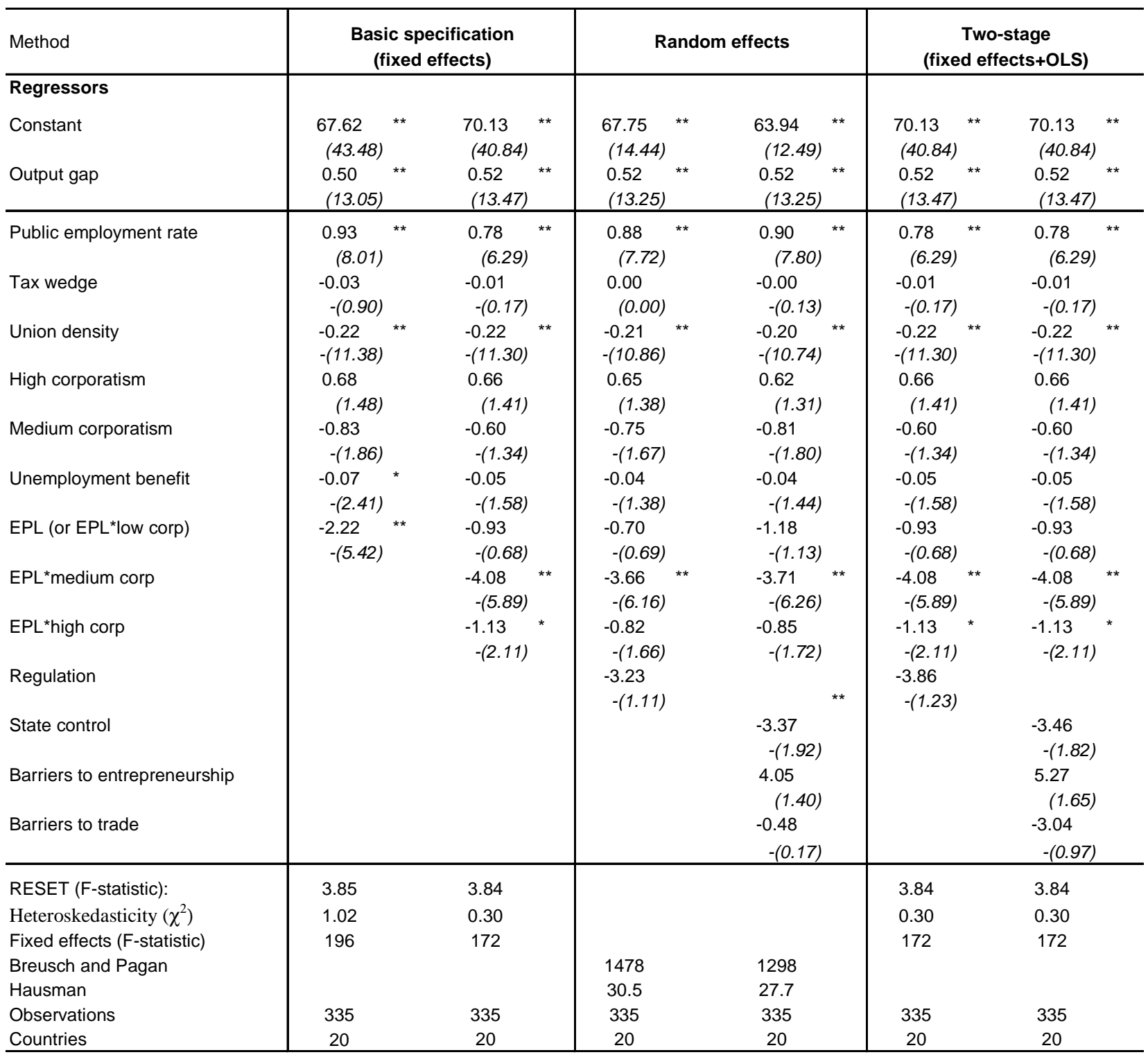

Note: T-statistics are in brackets.

*, ${ }^{* *}$ denote significance at the $5 \%, 1 \%$ level, respectively.

Source: Nicoletti and Scarpetta (2001). 


\subsection{Insecurity and inequality}

\subsubsection{Regressions for manufacturing industries}

139. Reduced-form regression models, similar to the panel models for service industries discussed in the main text, are used here to analyse the impacts of regulations and institutions on insecurity and inequality for manufacturing industries. Regression results for the entire set of insecurity and inequality measures are reported in Table A3.8. It should be noted that, for variables Workers with a year or less of job tenure, average job tenure and workers with temporary jobs, manufacturing is considered as an aggregate sector, implying that the regressions are limited to a cross-country analysis with very few degrees of freedom.

140. Tariff and non-tariff barriers to trade are the only indices of product market regulation that are available in manufacturing. In addition, these are uniform throughout the EU, except in so far as their relative importance is affected by differences in industry mix. This creates an additional difficulty because the country coverage of the insecurity and inequality measures is highly (sometimes, exclusively) concentrated among EU countries.

141. Results are presented for a basic model, including the regulatory and institutional regressors, as well as for an augmented model that also controls for industry and country effects. Overall, few estimated coefficients are significant and robust to the introduction of country and industry effects. Comparing these results to the ones referring to service industries (see Tables 15 and 17), it is clear that estimation results for manufacturing industries prove less informative. A good example of the fragility of the estimated coefficients is provided by the estimates corresponding to mean satisfaction with job security where, despite being statistically significant in both cases, the sign of the coefficient associated with non-tariff barriers depends on the type of regression used.

142. Limiting our attention to significant coefficients that are robust to the introduction of country and industry effects, the additional information provided by regressions associated with manufacturing industries is the following: $i$ ) results suggest that stricter EPL has a positive effect on the rate of working poverty; and ii) the output gap has greater explanatory power in manufacturing than was the case for service industries.

\subsubsection{Sensitivity analysis for service industries regressions}

143. Tables A3.9 and A3.10 report results for reduced-form regression models with specifications alternative to the ones reported, for service industries, in Tables 15 and 17. For reasons of brevity, the results shown are limited to three of the nine dependent variables, average job tenure, incidence of job losses resulting in long-term unemployment, and workers with low-paid jobs. In each case, the estimation results from the main text are compared with those for models modified by: $i$ ) adding interactions of the global measure of product market regulations with two types of labour market variables, EPL strictness and a measure of wage bargaining structure (corporatism); $i$ ) restricting the regression sample to sectors for which the dependent variable and product and labour market regulations are available at exactly the same industry level of detail; and iii) replacing the industry panel specification by cross-sectional regressions using aggregate national values.

144. Most of the interaction variables are statistically insignificant and do not provide additional information on the impact of regulations and institutions on insecurity or inequality. In fact, for both average job tenure and incidence of job losses resulting in long-term unemployment, the qualitative results 
presented in Section IV remain unchanged. However, for workers with low-paid jobs, the interaction between product market regulations and EPL is positive and statistically significant, suggesting that the effects of these two types of regulation are mutually reinforcing.

145. Restricting the sample to those sectors for which a "perfect match" exists has little effect on the regression results in most cases. However, the restricted sample estimates differ somewhat from the reference results for workers with low-paid jobs. Finally and as expected, given the very low degrees of freedom, cross-sectional regressions using aggregate national values prove to be uninformative. 
Table A3.8. Policies, institutions and insecurity and inequality ${ }^{1}$ Results of regressions for manufacturing industries

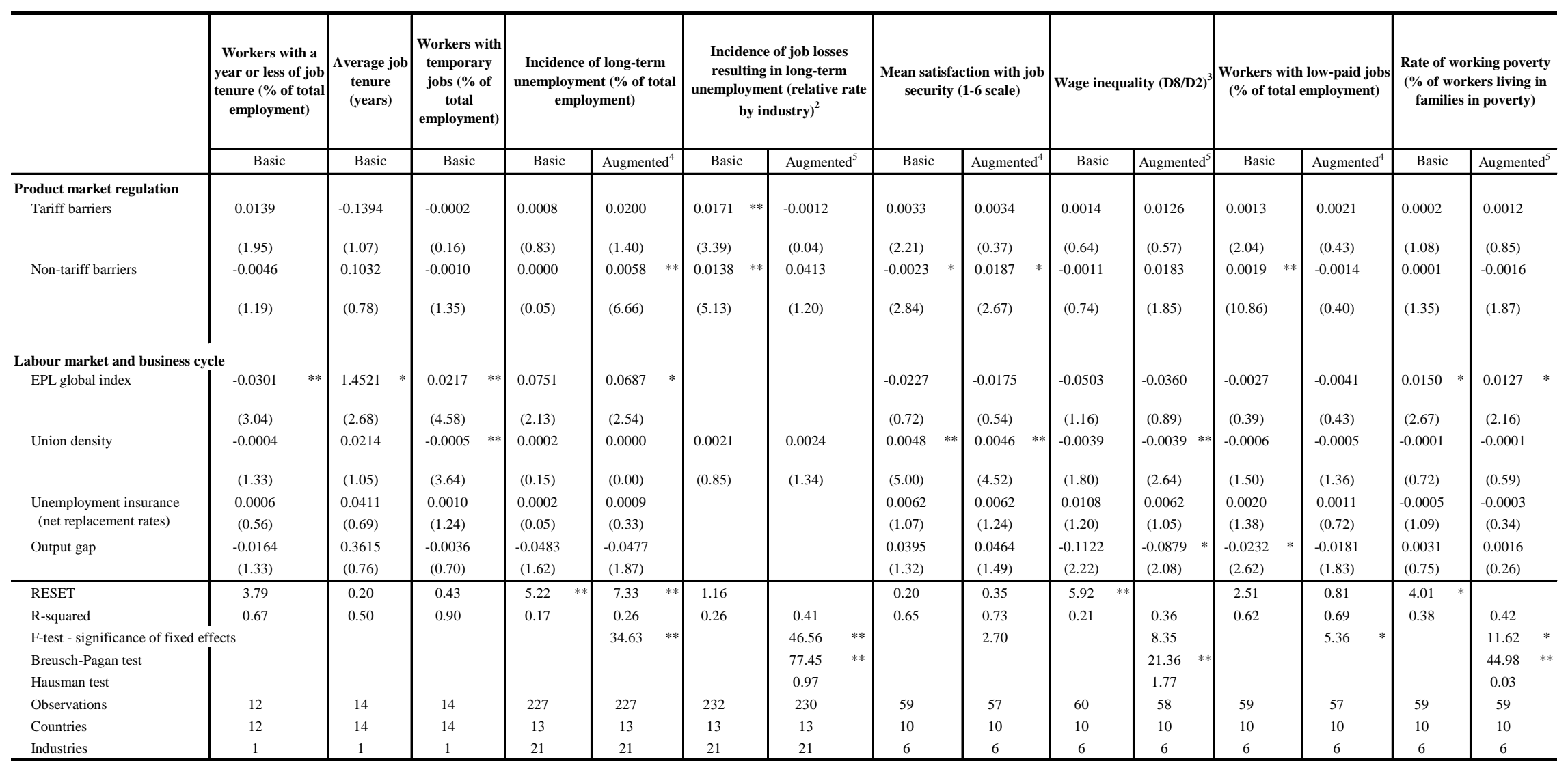

1. See Tables 14 and 16 for the definitions of the insecurity and inequality measures (i.e. the dependent variables), respectively.

2. Regressors with no inter-industry variation within a country are not used for this dependent variable, since there cannot be common effects across all industries in their relative risk of job los

3. D8/D2 refers to the ratio of wage rates at the breakpoint between the eigth and the ninth deciles and the breakpoint between the second and the third deciles.

4. Basic model augmented to include industry fixed effects. It is estimated by OLS, the standard errors being adjusted for clustering.

5. Basic model augmented to include industry fixed effects and country random effects. It is estimated by GLS.

Note : *** denote significance at the $5 \%$ and $1 \%$ level, respectively. All equations include a constant. T-statistics are reported in parentheses.

Outliers based on the Welsch distance cut-off [Chatterjee and Hadi (1988)] are omitted from the sample.

Basic model is estimated by OLS, the standard errors being adjusted for clustering. 
Table A3.9. Policies, institutions and insecurity: Sensitivity analysis

ECO/WKP(2001)38

Regression estimates using alternative specifications

Panel A. Dependent variable is average job tenure (years) ${ }^{1}$

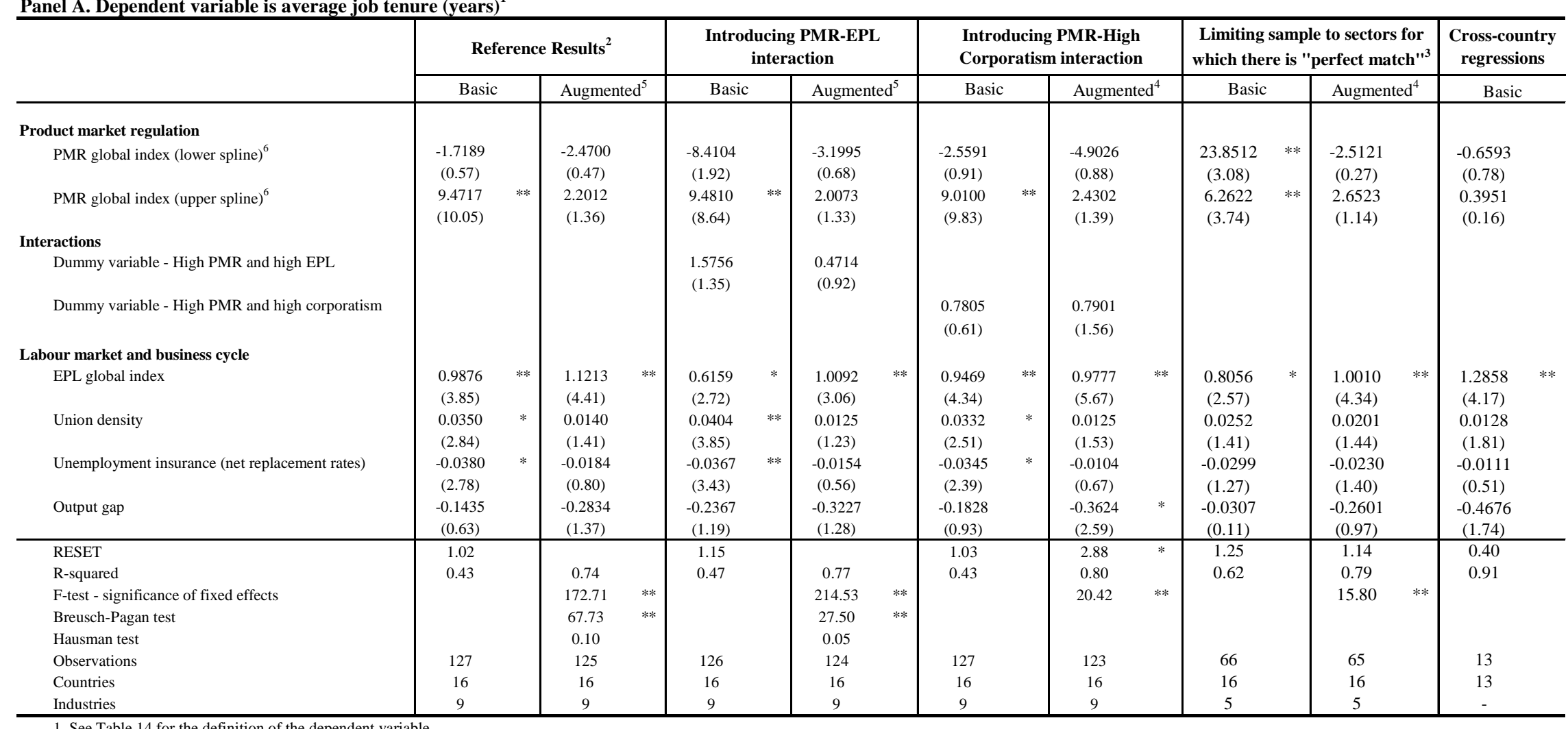

1. See Table 14 for the definition of the dependent variable.

2. As reported in Table 15.

3. A "perfect match" exists when measures for the dependent variable and product and labour market regulations are available at exactly the same industry level of detail.

4. Basic model augmented to include industry fixed effects. It is estimated by OLS, the standard errors being adjusted for clustering.

5. Basic model augmented to include industry fixed effects and country random effects. It is estimated by GLS

6. The effects of the global index for PMR are modeled as linear splines with a single kink point.

Note : *** denote significance at the $5 \%$ and $1 \%$ level, respectively. All equations include a constant. T-statistics are reported in parentheses.

Outliers based on the Welsch distance cut-off (Chatterjee and Hadi, 1988) are omitted from the sample.

Basic model is estimated by OLS, the standard errors being adjusted for clustering. 
Table A3.9. Policies, institutions and insecurity: Sensitivity analysis (continued)

Regression estimates using alternative specifications

Panel B. Dependent variable is the incidence of job losses resulting in long-term unemployment (relative rate by industry) ${ }^{1}$

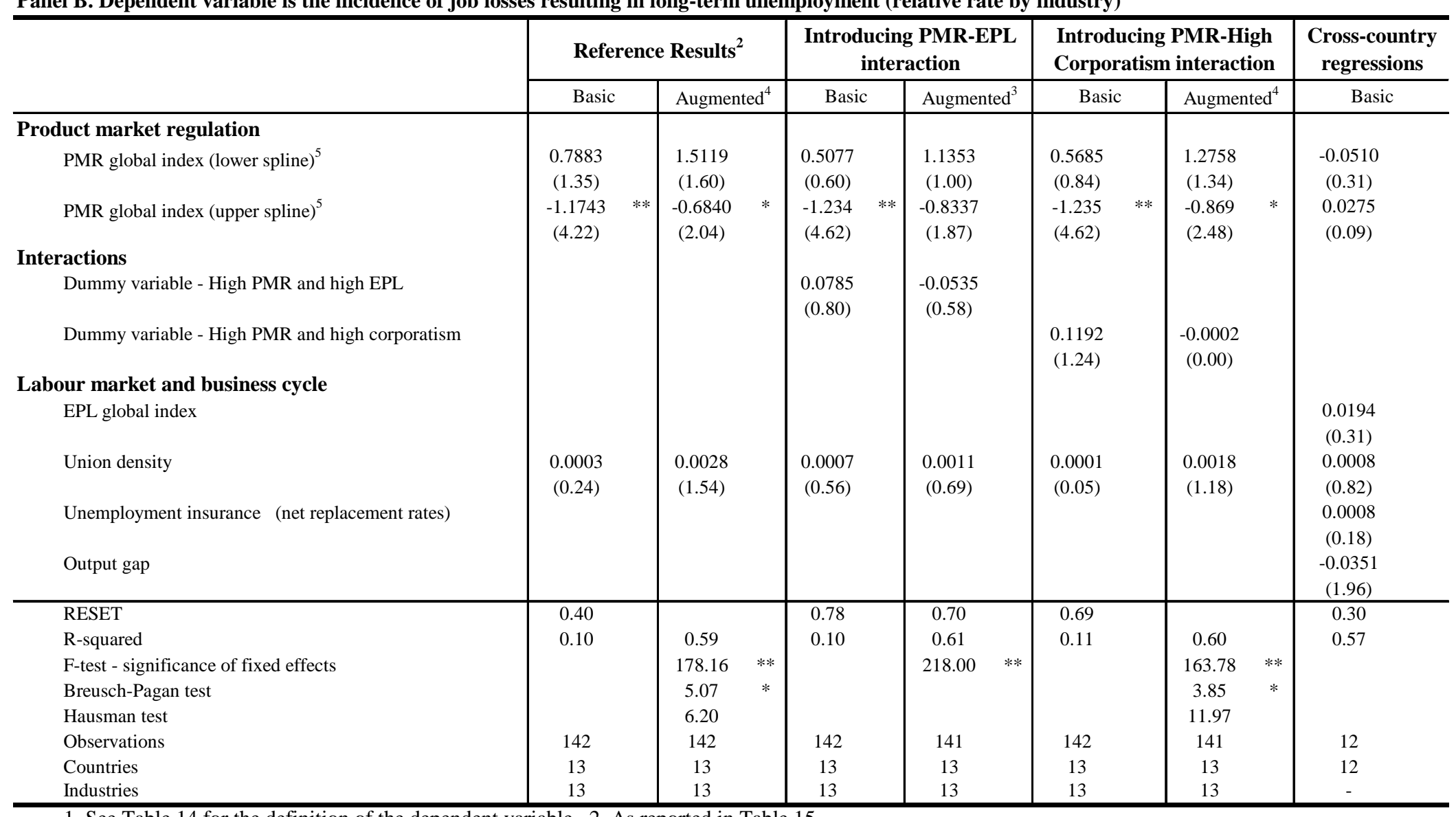

1. See Table 14 for the definition of the dependent variable. 2 .As reported in Table 15.

3. Basic model augmented to include industry fixed effects. It is estimated by OLS, the standard errors being adjusted for clustering.

4. Basic model augmented to include industry fixed effects and country random effects. It is estimated by GLS.

5. The effects of the global index for PMR are modeled as linear splines with a single kink point.

Note :*** denote significance at the 5\% and $1 \%$ level, respectively. All equations include a constant. T-statistics are reported in parentheses.

Outliers based on the Welsch distance cut-off (Chatterjee and Hadi, 1988) are omitted from the sample. 
ECO/WKP(2001)38

Table A3.10. Policies, institutions and inequality: Sensitivity analysis

Regression estimates using alternative specifications for workers with low-paid jobs (percentage of total employment) ${ }^{1}$

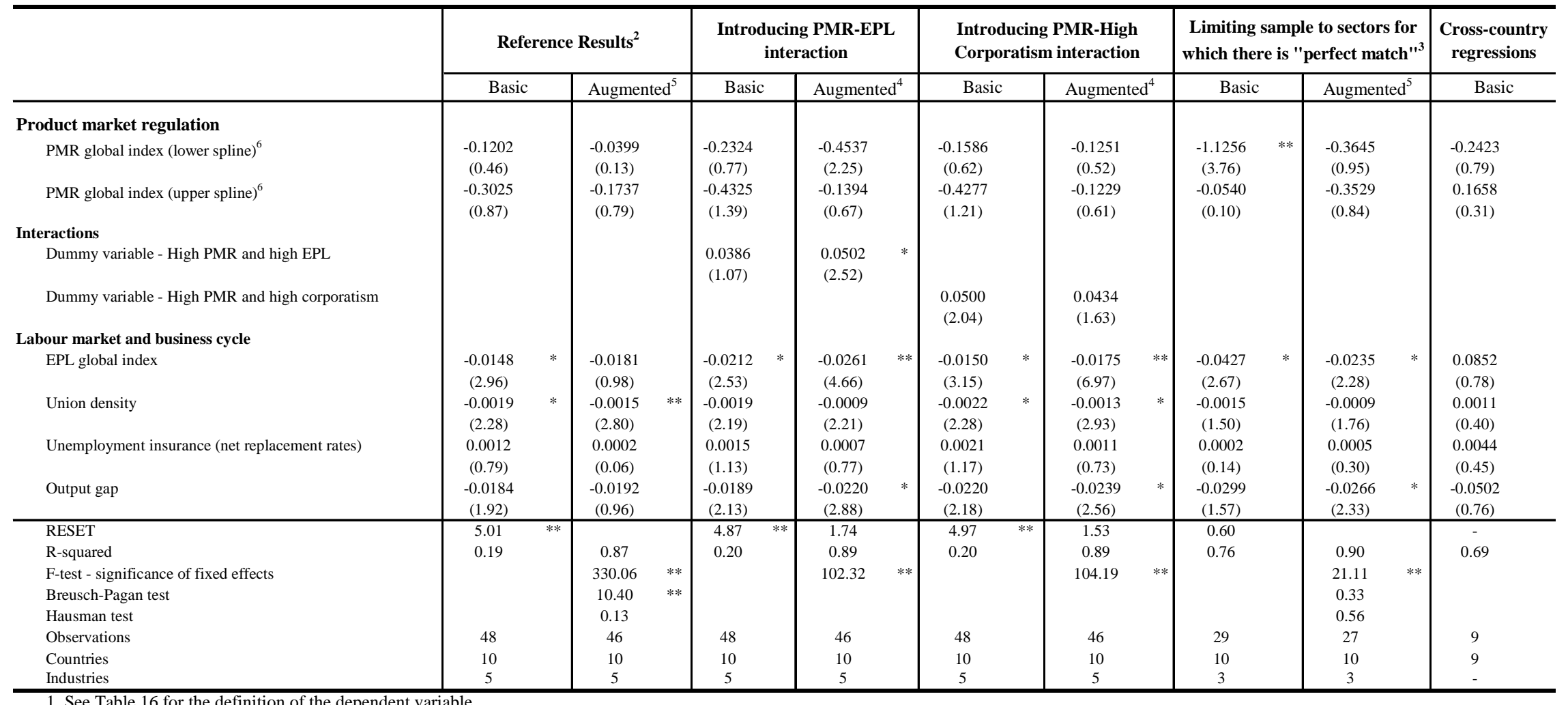

1. See Table 16 for the definition of the dependent variable.

2. As reported in Table 17 .

3. A "perfect match" exists when measures for the dependent variable and product and labour market regulations are available at exactly the same industry level of detail.

4. Basic model augmented to include industry fixed effects. It is estimated by OLS, the standard errors being adjusted for clustering.

5. Basic model augmented to include industry fixed effects and country random effects. It is estimated by GLS.

6. The effects of the global index for PMR are modeled as linear splines with a single kink point.

Note : *,* denote significance at the $5 \%$ and $1 \%$ level, respectively. All equations include a constant. T-statistics are reported in parentheses.

Outliers based on the Welsch distance cut-off (Chatterjee and Hadi, 1988) are omitted from the sample.

Basic model is estimated by OLS, the standard errors being adjusted for clustering. 


\section{REFERENCES}

CHATTERJEE, S., and A. HADI (1988) Sensitivity Analysis in Linear Regression, New York: Wiley.

DAVIDSON, R., and J. MACKINNON (1981), "Several Tests of Model Specification in the Presence of Alternative Hypotheses", Econometrica, Vol. 49, pp. 781-793.

JEAN, S. and G. NICOLETTI (2001), "Product market regulation and wage premia in Europe and NorthAmerica: An empirical investigation", OECD Economics Department Working Paper, forthcoming, Paris.

MOULTON, B.R. (1986), "Random group effects and the precision of regression estimates", Journal of Econometrics, 32, pp. 385-397.

NICOLETTI, G. and S. SCARPETTA (2001), "Interactions Between Product and Labour Market Regulations: Do They Affect Employment? Evidence from OECD Countries", OECD Economics Department Working Paper, forthcoming, Paris.

NICOLETTI, G., S. SCARPETTA and O. BOYLAUD (1999) "Summary indicators of product market regulation with an extension to employment protection legislation", OECD Economics Department Working Papers, n. 226, Paris. 


\section{ECONOMICS DEPARTMENT}

\section{WORKING PAPERS}

311. Modelling Import Responsiveness for OECD Manufactures Trade (October 2001) Mara Meacci and David Turner

310. Trade Linkages and the Trade Matrices in the OECD Interlink Model (October 2001) Laurence Le Fouler, Wim Suyker and Dave Turner

309. Encouraging Environmentally Sustainable Growth in Australia (October 2001) Ann Vourc'h and Robert Price

308. Financial Market Liberalisation, Wealth and Consumption (September 2001) Laurence Boone, Nathalie Girouard and Isabelle Wanner

307. The Economic Integration of Germany's New Länder (September 2001) Eckhard Wurzel

306. Standard Shocks in the OECD Interlink Model (September 2001) Thomas Dalsgaard, Christophe André and Pete Richardson

305. Fiscal Implications of Ageing: Projections of Age-related Spending (September 2001) Thai Thanh Dang, Pablo Antolin and Howard Oxley

304. The Width of the Intra-European Economic Borders (August 2001) Alain de Serres, Peter Hoeller and Christine de la Maisonneuve

303. Surveillance of Tax Policies: A Synthesis of Findings in Economic Surveys (July 2001) Paul van den Noord and Christopher Heady

302. Reforming the Tax System in Portugal (July 2001) Chiara Bronchi, José C. Gomes-Santos

301. Tax Systems in European Union Countries (June 2001) Isabelle Joumard

300. Encouraging Environmentally Sustainable Growth in Belgium (June 2001) Paul O’Brien, David Carey, Jens Høj, Andreas Woergoetter

299. Encouraging Environmentally Sustainable Growth in Poland (June 2001) Grzegorz Peszko, Patrick Lenain

298. Tracking the Euro (June 2001) Vincent Koen, Laurence Boone, Alain de Serres, Nicola Fuchs

297. Firm Dynamics and Productivity Growth: A Review of Micro-evidence from OECD Countries (June 2001) Sanghoon Ahn

296. How should Norway Respond to Ageing? (May 2001) Pablo Antolín and Wim Suyker

295. How will Ageing Affect Finland?

(May 2001) Pablo Antolín, Howard Oxley and Wim Suyker 


\section{ECO/WKP(2001)38}

294. Sectoral Regulatory Reforms in Italy: Framework and Implications (May 2001) Alessandro Goglio

293. Encouraging Environmentally Sustainable Growth: Experience in OECD Countries (May 2001) Paul O’Brien and Ann Vourc'h

292. Increasing Simplicity, Neutrality and Sustainability: A Basis for Tax Reform in Iceland (May 2001) Richard Herd and Thorsteinn Thorgeirsson

291. Options for Reforming the Tax System in Greece (April 2001) Chiara Bronchi

290. Encouraging Environmentally Sustainable Growth in Canada (March 2001) Ann Vourc'h

289. Encouraging Environmentally Sustainable Growth in Sweden (March 2001) Deborah Roseveare

288. Public Spending in Mexico: How to Enhance its Effectiveness (March 2001) Bénédicte Larre and Marcos Bonturi

287. Regulation in Services: OECD Patterns and Economic Implications (February 2001) Giuseppe Nicoletti

286. A Small Global Forecasting Model (February 2001) David Rae and David Turner

285. Managing Public Expenditure: Some Emerging Policy Issues and a Framework for Analysis (February 2001) Paul Atkinson and Paul van den Noord

284. Trends in Immigration and Economic Consequences (February 2001) Jonathan Coppel, Jean-Christophe Dumont and Ignazio Visco

283. Economic Growth: The Role of Policies and Institutions.

Panel Data Evidence from OECD Countries

(January 2001) Andrea Bassanini, Stefano Scarpetta and Philip Hemmings

282. Does Human Capital Matter for Growth in OECD Countries? Evidence from Pooled Mean-Group Estimates (January 2001) Andrea Bassanini and Stefano Scarpetta

281. The Tax System in New Zealand: An Appraisal and Options for Change (January 2001) Thomas Dalsgaard

280. Contributions of Financial Systems to Growth in OECD Countries (January 2001) Michael Leahy, Sebastian Schich, Gert Wehinger, Florian Pelgrin and Thorsteinn Thorgeirsson

279. House Prices and Economic Activity (January 2001) Nathalie Girouard and Sveinbjörn Blöndal

278. Encouraging Environmentally Sustainable Growth in the United States (January 2001) Paul O’Brien

277. Encouraging Environmentally Sustainable Growth in Denmark (January 2001) Paul O’Brien and Jens Høj 